\title{
,
}

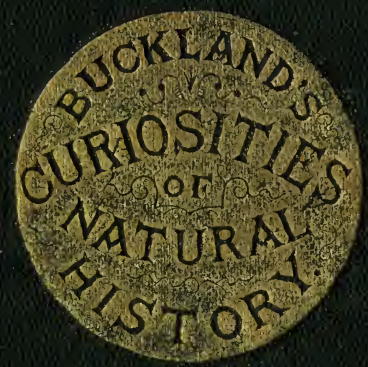




\section{THE UNIVERSITY OF ILLINOIS LIBRARY}

From the collection of

Julius Doerner, Chicago Purchased, 1918.

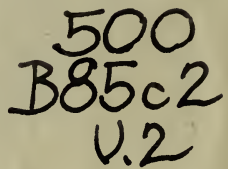





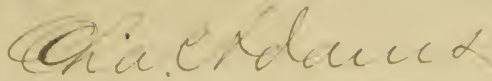 \\ CURIOSITIES \\ OF \\ C) Gixid Sertes.}

NATURAL HISTORY.

$\mathrm{BY}$

FRANCIS T. BUCKLAND, M.A.

LATE STUDENT OF CHRIST CHURCH, OXFORD ;

yER MAJESTX'S INSPECTOR OF SALMON FISHERIES; ETC.

SECOND EDITION.

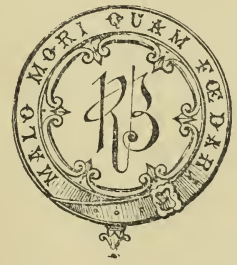

IN TWO VOLUMES. - VOL. II.

\section{LONDON :}

RICHARD BENTLEY, NEW BURLINGTON STREET,

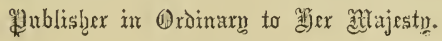

1868. 
LONDOX

PRINTED BY SPOTTISWOODE AND CO. JEW-STREET SQUARE 


\section{0 \\ $B 8502$ \\ CONTENTS \\ $\mathrm{OF}$ \\ THE SECOND VOL U ME.}

PAGE

PAGE

Exhibitions-Mr. J. Brice

The Giant's Attendants . . 18

the French Giant . . .

1 Giants in general . . . 19

Appearance of the French O'Brian, the Irish Giant . 20

Giant

2 The Giants Cotter and Frenz 21

The Giant's History . . .

The Giant and the Troop-

Horses . . . .

Ieasurements of the French

Giant . . . . . 5

The Giant's Shoes . . . 6

The Giant and the Cabman

Tall Englishmen . . .

The Geology of a District influences Stature . .

Chang, the Tall Man of Fychow . . . . . 10

Creating a Sensation . . 11

A Visit to the Chinese Giant . . . . . 12

Chang's graceful Manners . 13

Chang's Speech . . . . 14

Chang's Autobiography . . 15

Chang's Stature . . . 16

Nadame Chang and the

Bradley, of Market Weighton. . . . . . 22

4 Murphy, an Irish Giant . 23

Records of Giants . . 24

The Russian Giant . . 25

Dr. Hyrtl on Giants' Bones 26

7 Giants' Bonesin an Irish Bog 27

8 Human Skeleton on a Glacier . . . . . 28

9 Giant's Bones dug out of the Earth . . . . . . 29

Gigantic Fossil Bones . . 30

Giant's Skull at Leyden . 31

Giants of Seripture . . . 32

Height of Goliath of Gath . 33

Female Giants. . . . 34

Various Giants . . . . 35

M. Theret's South American

Giant . . . . 36

Probable Stature of $\mathrm{Og}$, King

17 of Bashan . . . . 37

Dwarf. . . . . 17

A 2 
Tradition of a Giant in Dauphiné . . . . . 38 Gigantic Child of Willingham . . . . . The Female Nondescript Julia Pastrana, Exhibitions of Human Mummies, \&c.

The Mummy of Julia Pastrana . . . . . . 41 Mexican Embalmment . . 42 A Guano Mummy . . 43 Egyptian Mummies . . . 44 Smuggling Mummies . . 45 The Showman and the Mummies

The Mummy Clock . . . 47 Decease of a Mummy . . 48 The Woolly Woman of Hayti Antoinette's Coiffure • . 50 Plica Polonica . . . . 51 An Arctic Dog . . . . 52 The Australian Fat Boy . 53 Contents of a Caravan . . 54 The Spotted Child . . 55 An ingenious Mother . . 56 The New Zealand Warrior Chiefs.

New Zealanders in London Performance of New Zealanders . . . . 59 The double War-dance . . Maori Songs and Wrestling New Zealand Chiefs at Lunch . . . . . 62 Shark's Teeth as Earrings . 63 Moko or Tattoo marks . . 64 Dicky's Speech . . . 65
Catastrophe after Lunch . 66 An alarming Visit . . . 67 New Zealanders' Horror of

Snakes . . . . 68 The Chiefs at the Zoologi-

cal Gardens . . . . 69 Evidence respecting the Moa 70 Wandering Mountebanks . 71 The "American Diver". . 72 The "Fire-Eater" . . . 73 The Card Engrarer's Ghost 74 The Infant Hercules. . 75 A dangerous Trick . . . 76 The disheartened Musician 77 The Stone Cracker . . . 78 The Stone Cracker's performance . . . . . 79 The Knack of Stone-cracking. . . . . . 80 Catch-pennies . . . . 81 Penny Microscopes . . . 82 Thames Water in Microscope Show . . . . . 83 An Optical Penny Show . 81 The Razor-paste Seller . . 85 The virtues of Razor-paste 86 Barnum's Baby Show . . 87 Barnum's Advertisement . 88 Barnum's Baby Show . . 89 English $v$. American Babies 90 Barnum's Exhibition . . 91 Olmar walks with his Head downwards . . . . 92 The Ladder Feat . . . . 93 Olmar's Muscular Development . . . . . . 94 The Aërial Walking Lesson 95 The Trapeze Bar . . . . 96 
The Indian Rope Feat . . 97 Herr Tolmaque's Rope Performance .

The Living Skeleton . . . 99 The Rope Feats at Dinan , 100 Natator, or the Human Frog 101 Natator eats a Bun under Water

Drinking and Smoking under Water

Organs of Hearing in Fishes 104 The Porpoise Trick . . . 105 Accident to Natator's glass Tank . . . . . 106 The performing Bull, Don Juan .

Description of the performing Bull . . . . . 108 The Bull's Feats . . . . 109 Don Juan's good disposition 110 Jamrach's Animal Store . 111 Six thousand Parakeets . . 112 Jamrach's Stable-yard . . 113 Head-quarters of the Animal

Trade. . . . . 114 Performing Fleas. . . 115 The Flea Market . . . 116 A Battle of Fleas. . . . 117 Kussian Fleas . . . . 118 How to Train Fleas . . . 119 Docility of Fleas . . . . 120 The various Flea Performers . . . . . . 121 Fleas at their Meals . . 122 The Patriarch Flea . . . 123 The Elephant Horse . . . 124 The Three-legged Horse . 125 The Dutch Groom . 126
PAGE

The Three-legged Cow . . 127 The Talking Fish . . . 128 Jenny's Performances . 129 Jenny's Vocal Powers . . 130 The Sea Bear . . . . . 131 The Sea Bear Tamed . . 132 Death of the Sea Bear . . 133 Mermaids . . . . . 134 The Regent Street Mermaid 135 The Nermaid "Out of Luck" . . . . . 136 The Japanese Mermaid . . 137 The latest thing in Mermaids. . . . . 138 Barnum's Mermaid . . 139 The Nondescript . . . . 140 The Nondescript's Appearance . . . . . 141 Structure of the Nondescript 142 A Mermaid and Nondescript

Manufactory . . . 143 The Dugong . . . . 144 Dugong Oil. . . . . 140̃ The Mermaid-The Giant

Pig-The Monster of the

Deep . . . . . . 146 The Monster Pig . • . 147 The Yorkshire Hog . . . 148 Wallace the Little . . 149 The Monster of the Deep . 150 Blondin $v$. the Monkey . . 151 Blondin's imitation of an Ape . . . . . . 152 Anatomical Construction of

a Monkey's Foot . . . 153 Monkeys of the Old and New

World. . . . . 154 Blondin's wonderful Leap . 155 
How Blondin accomplishes

his Leap . . . . . . 156

Blondin's Escape from a Di-

lemma.

Physiognomy influenced by

Occupation . . . . 158

Eagle made of Copper . . 159

Construction of the Copper

Eagle. . . . . . 160

The Copper Feathers . . 161

Colouring Copper. . . 162

The Zine Eagle . . . . 163

The Marble Lady . . . . 164

The Petrified Lady and her

Dog . . . . . . 165

The "growing" Plate . . 166

Chemical decomposition of

Earthenware . . . 167

Efflorescent Salts . . . 168

A Sprouting Tea-pot. . . 169

The Anthropoglossos, or Me-

chanical Vocalist . . 170

The Wax Head . . . . 171

Testing the Anthropoglos-

sos. . . . . . . 172

A Request to the Reader . 173 Antiquities — The Bone-

house at Ripon Cathedral 174

The Crypt at Ripon . . . 175

Polished Bones . . . . 176

Calculation of the Contents

of the Crypt . . . . . 177

Question by the late Duke

of Wellington . . . 178

Possible Age of the Bones . 179 Ancestral Skulls . . . 180 The Crypt of Hythe Church 181 The Battle of Hythe. . . 182
The Battle-field

PAGE

Difference between British

and Danish Skulls . 184

The Teeth of the Ancient

Britons . . . . 185

Skulls of Drummer-boys . 186

Wounds on the Skulls . 187

Conjectures about the Bones 188

Rothwell Bone-house . . 189

Contents of the Crypt at

Rothwell. . . . . 190

Tradition of a Plague at

Rothwell. . . . . 191

Collections of Bones in Not-

tingham and Hants . 192

Mortuary Chests at Win-

chester Cathedral . . . 193

The Remains of Kynegils

and Ethelwulf . . . 194

The Remains of Kenulph

and Egbert . . . . 195

The Mingled Remains of

Canute, Rufus, \&c. . 196

The Remains of Edred . . 197

Skull found at Aldershot

Camp . . . . . . 198

Wounds on the Aldershot

Skull . . . . . . 199

A Mystery . . . . . 200

An Explanation . . . 201

Russian Skulls . • . . 202

Highwaymen on Aldershot

Heath . . . . . 203

Hiding Bank-notes . . 204

How to Conceal Money and

Jewels . . . . . 205

Discovery of a Skeleton at

Doncaster . . . 206 
PAGE

Identification of the Skeleton.

A Child's Head or "Summut" . . . . . 208

Inquest on a Roman Noble 209 Skeléton of a Red Colour . 210 Colouring Matter in the Bones . . . . . 211 Posthumous Coquetry . 212 Relics of Old London . . 213 Old Bethlehem Hospital . 214 Discorery of the Remains of John Hunter in the Vaults of St. Martin's - in - theFields . . . . . 215 John Hunter . . • . . 216 Memoir of John Hunter . 217 The Search forJohn Hunter 218 The Register . . . . . 219 The Vaults of St. Martin'sin-the-Fields . . . 220 Vault No. 3 . . . . . 221 Inspection of Coffins. . . 222 Confliction of Names . . 223 Will our Search be Successful?

We Find the Coffin . . 224 Condition of the Coffin . . 225 Results of the Discovery . 226 Reinterment of John Hunter 228 Inscriptions on the Coffin Plate. The Ceremony in Westminster Abbey . • . . . 230 Monumental Brass over the Grave . . . . . 2:31 Statue to John Hunter . . 232 The Statue Committee
Statue in the Museum by Weekes . . . . 234 The Hunterian Medal . . 235 Testimonial from the Royal

College of Surgeons . . 236 Acknowledgement . . . 237 The Skull of Ben Jonson . 238 Ben Jonson's Grave . . . 239 Charles I. and Ben Jonson 240 Remarkable position of Ben Jonson's Coffin . . . . 241 The Skull Hidden . . . 242 Investigations . . . . 243 TheClerk of theWorks' Story 244 The Skull twice Discovered 245 Bon Jonson's Skull still in

the Abbey . . . . . 246 History of the Gravestone . 247 Who Ordered the Inscription . . . . . . 248 Natural History of the Salmon-Notes in Ireland: Galway and Connemara 249 Practical Natural History . 250 What to Observe . . . 251 Requisites for a Salmon Fishery . . . . . 252 Instead of Killing Animals

Watch them. . . . 253 The Salmon's Home . . . 254 A Herd of Water-cattle. . 255 The Galway Salmor-ladder 256 Fish-ladders in the Thames 257 A Bath in a Salmon-ladder 258 Astonishing a Water-bailiff. 259 A New Clause in the Act . 260 The Salmon-nets . . . 261 The Galway Fishery • . . 262 
Arrivals from the Sea PAGE Shooting the Nets . . . 264 A Good Haul . . . . . 265 How the Nets are Worked . 266 Salmon out at Sea . . . 267 Food of the Salmon . . . 268 The Salmon takes the Fly

for a Shrimp . . . . 269 "Salmo Salar's" Opinion of the Fly . . . . . 270 Black-backed Salmon . . 271 Bog-water colours Fish . . 272 Local Names of Autumn Salmon . . . . . 273 Salmon wounded by Hakes 274 The Poacher's Defence . . 275 Poaching Instruments . . 276 The Chinaman Gaffed . . 277 Hang-qui-lo . . . . . 278 Mill-wheels - Experiments

on Salmon, \&c. . . . . 279 Salmon in Mill-arches . . 280 Millers' Men $v$. Salmon . . 281 Gratings for Mill-races . . 282 Dr. Carte's and Mr. Brady's

Gratings . . . . 283 Woodman's Grating . . 284 Action of the Grating . . 285 Objections to the Gratings . 286 Mr. Ffennell's Net Plan : 287 Action of the Net. . . . 288 Norwegian Poaching. . . 289 How to frighten Fish from Mill-wheels . . . . 290 Colour of Salmon when in

Water. Eye of Salmon.-Its Weight in Water.

Salmon in Harness PAGE Traction-power of a Salmon 294 Transport of Salmon . . 295 Pulse of Salmon . . . . 296 Gregarious Habits of Salmon • • . . . . 297 Salmon pairing . . . 298 Nesting-time . . . . 299 Smolts going to Sea . . . 370 Accident at Aldershot . . 301 Respiration of Fish . . . 302 Fish feel their Way . . . 303 Return of Grilse . . . 304 Marked Grilse . . . . 305 Nature's Provision against

Failure of the Race . 306 Probable Age of Salmon . 307 How to Mark Salmon . . 308 The Intemperate Salmon . 309 The Success, or otherwise, of

Salmon Fisheries . . 310 Lough Corrib . . . . . 311 Spanish Origin of Galway

Town . . . . . . 312 Fossil Butter . . . . 313 Fossil Pork. . . . . 314 Adipocere . . . . . 315 Angling Monks-Cong Ab-

bey. . . . . . 316 The Cong Salmon Pass . . 317 The poor Lunatic. . . 318 A desolate Scene . . . . 319 Salmon-hatching on a Large Scale . . . . . . 320 Pond for Salmon-fry . . 321 Water Tigers . . . . 322 The Massacre of the Innocents . . . . 323 
Murder in a Bottle . . . 324

Detection and Execution of the Culprit . . . . . 325 Water Vermin . . . . 326

Ponds Unfavourable for Salmon-fry . . . . . 327

Maam in the Wilderness . 328

A Pocket Switzerland . . 329

Effects of Frost on Spawning

Salmon . . . . . 330

Human Remains in Glacier 331

Hill Fairies . . . . 332
Moonlight Walk in Search of Fairies . . . . . 333 Water Fairies . . . . 334 Jemmy the Pearl Collector 335 Pearls from Corrib Mussels 336 Diving for Pearls . . . 337 Cruelty Martin . . . . 338 Bos Longifrons . . . . 339 "Pining" the Pig . . . 340 The "Pine" and the "Cripple" . . . . . 341 TheTrue Secret of Happiness 342

\section{APPENDIX.}

Exhibition of Vermin-Traps by the Royal Society for Prevention of Cruelty to Animals . . . . . 343 Varieties of Traps . . . 344 "Habeas Corpus" Trap . 345 Mind $v$. Instinct . . . . 346 Award of Committee . . . 347 Prize Vermin Traps . 348,349 New 'Zealand Moa . . . 350 Latest Intelligence of the

Moa . . . . . 351 Development of the Flea . 352
To drive away Fleas . . . 353 Act for Burying in Woollen 354 Burying in Woollen . . 355 Coffins in St. Mary's Vaults 356 Transport of Live Salmon . 357 How toWeigh a Live Salmon 358 Journeyin the Railway Van with the Salmon . . . 359 Difficulties in the Train . 360 Arrival at Paddington . . 361 The Salmon and the Sturgeon . . . . . 362 Bog-Butter . . . 363-365 


\section{ILLUSTRATION IN THE SECOND VOLUME.}

The Nondescript . . . . . To face page 140 


\section{EXHIBITIONS.}

\section{J. BRICE, THE FRENCH GIANT.}

"I AM the agent and interpreter of a French subject; he is a giant; his height is 8 feet; his weight 30 stone; his age 22 ; of a pleasing exterior. I take the liberty to offer him to your lordships' notice, \&c. \&c."

The above paragraph caught my eye among the advertisements of "The Times," in May, 1862-just at the time the Great Exhibition was about to be opened.

It appears that the giant had offered his services in costume on this memorable occasion, but they were refused.

Thinking it likely that he would not leave London without exhibiting himself, I made inquiries as to his whereabouts, and at last discovered him.

On my first introduction to M. Joseph Brice (for that is his name), I confess I felt, literally, "very small ;" but, after a few minutes' conversation, recovered from SER. III.-VOL. II. 
my feelings of " smallness," and at once perceived that my friend was not only a giant, but also un bon garçon.

Giants, for the most part, exhibit enormous proportions of limbs at the expense of the mental powers. M. Brice is an exception to this rule; he is courteous and affable to strangers ; and his manners are so agreeable, that his visitors feel at ease in his presence, and not gauché and uncomfortable, as English people are too apt to feel when they try to do the civil to Frenchmen. $\mathrm{He}$ is fond of conversation, and there is a sly vein of humour in his remarks; he is the "Good-natured Giant," and not the fierce Fe-Fo-Fum ogre of the nursery tales.

When I first made acquaintance with him, he was dressed in the uniform of the Tambour-Major (drum major) of the French Imperial Guard. In this costume he looked really magnificent. His age was 22 years. The handbills stated that his height was 8 feet; it really was about 7 feet $6 \frac{1}{2}$ inches, from that to 7 feet 7 inches. Anyhow, a doorway 7 feet $6 \frac{1}{2}$ inches would not let him through without his stooping considerably. I would beg the reader just to mark out 7 feet 8 inches on the wall of his room, and compare his own height by the mark, and he will see to what an enormous stature M. Brice had attained.

The following is the personal history of the giant :- 
His name is Joseph Brice. He was born at the village of Ramonchamp, in the Vosges, a chain of mountains bounding the valley of the Rhine on the west, from the neighbourhood of Muhlhausen, to that of Mayence; the chain is partly in France, partly in the Rhenish province of Bavaria.

M. Brice was born in that part of the range which belongs to France, and hence he sometimes calls himself "The Giant of the Mountains." He speaks French perfectly, without the least trace of a patois.

His parents were hard-working, respectable farmpeople: they were by no means gigantic themselves, but about the ordinary size of French peasants.

At his birth there was nothing to indicate that he was about to grow to his present stature, and up to the age of six years, his height did not exceed that of most children of his age. After a short illness, he began to assume such gigantic proportions that his parents were much alarmed about him, but still he continued to grow and enjoy perfect health.

At the age of thirteen he was equal in height to his father and the generality of the neighbouring farmers.

The phenomenon of his being as tall as a man and yet showing all the habits and actions of a child, caused him to be the talk of the neighbourhood, and to suffer at the same time great personal discomfort; for the 
children would not play with him, the men could not associate with him.

At the age of sixteen he commenced to exhibit himself in public, and visited the principal towns in France, and also Paris, where he was well received, not only by the Emperor himself, but by the public in general.

I paid the giant several visits : somehow or another, we took a fancy to each other, and I did my best to render him what little services I could, as he was quite a stranger in England, and had not a single friend in London, and this he evidently felt much. I therefore determined to do my best to be a real friend to the poor giant-goodnatured, excellent, gentlemanlike fellow as he was!

We ultimately became great friends, and I invited him up to the Regent's Park Barracks, where I introduced him to my brother-Officers. It was great fun to see our great, tall Life-Guard Troopers stand by his side, or walk under his arm, and look up to him.

A very curious thing took place. At one of his visits I took him into the stables to see the troop-horses, and as he pissed the stalls, the horses shied and snorted at him. They were pretty well accustomed to tall men, but yet they actually shied at the giant! So he must have been something extraordinary, even in the eyes of horses.*

* It is supposed by some that the eyes of horses magnify objects 
After I had known him some time, I persuaded the giant to allow me to take his measurements (N.B., I was obliged to get on a chair to do it). They were as follows :-

\begin{tabular}{|c|c|c|c|c|}
\hline \multirow{2}{*}{\multicolumn{3}{|c|}{ Actual height }} & & \multirow{2}{*}{ Inches } \\
\hline & & & & \\
\hline Circumference of $h$ & head & & & 25 \\
\hline ound the chest & & & & \\
\hline he shoulde & & & & 25 \\
\hline eng & umerus) & & & \\
\hline Leng & (radius) & & & 25 \\
\hline Cire & forearm & . & & \\
\hline Leng & finger. & & & \\
\hline ian & & & & \\
\hline Leng & one (femur) & & & \\
\hline Length of leg-bone & e (tibia) & & & \\
\hline Length of foot & . . & & & $15 \frac{1}{2}$ \\
\hline Diameter of foot & & & & \\
\hline tretch of arms & & & & \\
\hline
\end{tabular}

At my request, he was good enough to extend his arms at full length against the wall, and I found his full stretch to be no less than $95 \frac{1}{2}$ inches; in fact, he very nearly answers to the dimensions that every well-made man ought to show on measurement. And I have this on the authority of an eminent sculptor. The rule is this: If a measure be taken from the exact centre of the body, and the person stand spread-eagle fashion, the measure ought to

much more than do human eyes. Brice must indeed have appeared a monster to our Life-Guard troopers. 
describe a circle, the circumference being marked by the end of the outstretched hand and arm, and of the leg and foot-these limbs forming the radii of a circle.

Casts of the giant's hand were taken at my suggestion, and I have two casts now in my possession. He also presented me with a pair of his shoes, which are, indeed, regular canoes : they measure 1 foot 4 inches in length, and $5 \frac{1}{2}$ inches across.

After a while, the giant left London for a tour in the provinces. By a most extraordinary coincidence, almost wherever I went to lecture, I found my friend the giant also in the town, and this without either of us having the least idea of meeting. Thus, when I went to Sheffield, there was the giant; at Liverpool, Nottingham, and at Worcester, always the same thing; the giant was always pleased to see me as much as I was to see him. In the course of his travels in Ireland, he had fallen in love; and at Worcester he introduced me to Mrs. Brice-a very agreeable, good-looking, chatty girl-who has made the giant an excellent wife, and takes the greatest care of him.

In October, 1865, M. Brice and his wife returned to London, Mr. Anderson having engaged his services at St. James's Hall, where, in December 1865, he appeared as "Anak, King of the Anakims; or, The Giant of Giants." Just hefore his arrival, Chang, the Chinese 
giant, had been holding his levées at the Egyptian Hall, and Brice came up as a sort of rival. Brice is much the finer man of the two, in every way,-at least, to my taste.

On his arrival in London, I gave a dinner-party in honour of Mr. and Mrs. Brice. The giant, I observed, had grown somewhat. We made out his height to be (soldier measurement) about 7 feet 8 inches, and he was well and hearty.

He told me he had got into trouble at some country town for looking out of the window. The man who had agreed to pay him so much for a certain number of exhibitions observed a crowd staring up at the house. Going upstairs, he found Brice looking out of the windows, which were a great height from the floor. The money taker said that this was not fair as the townsfolk could thus see the giant for nothing.

When our party broke up, I sent for a cab. It was very amusing to see the cabman's face of semi-horror and astonishment when his fare came out into the streets in the dim gaslight; he seemed half inclined to jump on his box and bolt away as fast as his horse could go. The giant, however, put his elbow on the top of the cab, and told the man where to go. This pacified him a little; for the poor fellow, I believe, fancied we were playing some trick upon him.

After dinner, the giant showed us how far he could 
stretch his arm: the tops of his fingers touched the cornice of the room, just 9 feet 8 inches from the ground; in fact, he could "catch flies off the ceiling" if he stood on tiptoe.

I asked him if, in his travels in England, Ireland, or Scotland, he had met with any man taller, or nearly as tall, as himself. He told me the tallest men he had met with were as follows :-

1st. A gentleman (he believed of the legal profession) who came to see him at Haverfordwest, who measured 6 feet $8 \frac{1}{2}$ inches.

2nd. A man in the police force at Newcastle, who measured 6 feet $9 \frac{1}{2}$ inches.

3rd. John Greeve, of Pontefract, Yorkshire, who measured 6 feet $10 \frac{1}{2}$ inches.

The giant informed me that the greatest number of tall men * he observed in his tour throughout the United Kingdom, were in Yorkshire and Lancashire; and this

* A friend has kindly forwarded me a list of a remarkably tall family, the Cozens family, of Sandyhaven, Pembrokeshire. The father, mother, six sons and three daughters make between them seventy nine feet eleven inches, the average height of the thirteen people being six feet one and three-quarter inches.

P.S.-I observed at this time flaming handbills about London in which my name was printed in huge red letters as the authority for the measurements of the giant other than I have given above. I beg to inform the public that these bills were distributed without my knowledge or permission, and I am in no way responsible for the statements made. The giant himself had nothing to do with these bills. 
corresponds very much with my experience as medical officer of the 2nd Life Guards. The geological formation of a district, I found, in examining recruits for the regiment, has considerable effect upon the stature of its inhabitants;-coal-producing countries, as a rule, generally grow the tallest, and, at the same time, the largest-boned men.

When we were at that remarkably lively place, Maam, in the county of Galway, Ireland, I hear we were in what was called Joyces' Country.

This race of Joyces have been described as of great stature, exceedingly stout, and endowed with great strength-in fact, giants. Unfortunately I did not see any real living representatives of this gigantic race of Joyces. I was informed that fifty years ago the average weight of the men about Maam was from 15st. to 18 st., and that they were proportionately tall, and that they had all died out except one or two here and there. I also gained intelligence of an inhabitant of the Joyces' Country, who lived not very long ago, who was called Jack na Banna, or Jack of the Fiannel Waistcoat. I could not ascertain his height, but my informant told me "that his jaw was like a pig's jaw, and that a child could sail across the lake in one of his brogues." 


\section{CHANG, THE TALL MAN OF FYCHOW.}

ONE day in the autumn of 1865 , when in the express train on my road to report on a certain oyster-bed, I read in one of the daily papers an advertisement to the following effect:-

"Peto, the giant of Fychow. His height is stupendous, his strength Herculean, and his weight four tons. To be seen at Cremorne Gardens, admission free."

My friend Mr. Bartlett, Superintendent of the Zoological Gardens, happened to be with me in the train, and, upon my pointing out the advertisement to him, he said, "Oh, I know all about that; it is a capital sell. I know the giant's name very well. I saw him at Paris a few days since. He is a four-footed giant, with a precious long nose; in fact, he is a huge elephant that the authorities at the Jardin des Plantes wanted to get rid of. If you recollect, they have been advertising for many weeks past the expected arrival of the human Chinese giant, and this is simply a capital idea to cause 
a sensation." Of course I immediately went to see Peto; a very fine elephant was he, but amazingly savage withal. Of Peto and his antecedents at another time.

The day after the advertisement of Peto, the Giant of Fychow, appeared in the papers, I received a letter from Brice, the French Giant. The poor fellow was in a terrible state of mind about the arrival of his monstrous Chinese rival. He wanted to know all about him, and if it was really true that the Chinaman weighed four tons. Brice had evidently got into terrible confusion between Peto the giant Elephant and Chang the giant Man. I had to explain the facts to pacify him.

A few days afterwards, when walking down Piccadilly, I saw a Chinese approaching in the distance. Here, then, said I to myself, comes the real Chinese giant at last. As the man came nearer, I saw he was neither a Chinese nor a giant, but, on the contrary, a miserable-looking "sandwich-board" man, dressed in Chinese costume, and about as unlike a Chinese in appearance and physiognomy as any one I ever set eyes on. His face, instead of being of the "pudding" pattern, with almond-shaped eyes, was decidedly hatchet-shaped; his nose, instead of being of the pure Celestial snub type, decidedly Roman; and his hair, instead of being jet black and as straight as pomade could make it, was a brilliant red, and curled round 
the edge of his Chinese hat like the hair of a French poodle-dog. The advertisement, however, which this would-be Celestial placed in my hand, told me that Chang, the tall man of Fychow, was to be seen that evening at the Egyptian Hall, Piccadilly, at eight o'clock. They say that a "watched kettle never boils; " and I thought that afternoon a very long one, in my curiosity to pay a visit to the long-expected Chinese giant.

I was naturally among the earliest visitors to the illustrious stranger. On entering the room one was immediately, as it were, transferred to a private house in China. Chang was seen at the end of the room, sitting like a stone joss upon a kind of throne, to which one ascended by a flight of carpet-covered steps. He was dressed in the most lovely white satin garments, highly ornamented with beautiful devices wrought in needlework. At his right hand, on a sort of minor throne, sat his wife, and at his feet was seated the dwarf, also from China. The steps to the throne were guarded on each side by two Chinamen in their native costumepig-tails included. The whole party, both ladies and gentlemen, carried fans in their hands, and these they used incessantly, with a grace and elegance that I strongly advise any young lady given to flirting inmediately to practise and adopt. In a few minutes Chang rose majestically from his throne, and advancing to the front, still fanning himself, bowed right, left, and in front to 
the audience, with an ease and elegance that would send an ordinary dancing-master out of his mind. It was neither a lady's curtsey, nor yet the formal bow which we are sometimes obliged to make when habited in that odious garment the evening swallow-tail or "claw-hammer" coat, but a mixture of both a bow and a curtsey, manly, without conceit, yet reverential and respectful to the audience. The giant immediately began a speech in Chinese, bowing and fanning himself during its delivery, and when he had finished his oration, one of the guardians of the stairs went to a table and read a translation of it, that we, the spectators, might know what we had been listening to.

The poor Chinaman was very nervous, as it was evidently the first speech he had made in a foreign land, and to a crowded audience; but I learnt from Chang's printed autobiography, that his speech was to the following effect:-

"Rulers and people of the Western Countries,

"My name is Chang; I am nineteen summers old; I am a native of Fychow, a city in the Au-hwy province of the celestial Chinese empire. The Changs, as far back as the voice of the past speaks to me, have all been great (tall) men. My father, Chang Tzing, a scholar and disciple of Confucius; my grandfather, a sage, and famous for his wisdom; my great-grandfather, 
Chang, the man of war, of whose great deeds our poets love to sing, all were great men, of whom I am the least, the poor and humble representative. My elder brother, Chang Sou Gow, is a soldier in the Imperial army, at Foo-Chow-Foo. He is in height six inches under me; but in width and strength and massiveness, I cannot compare with him. He weighs four hundred pounds; he is known as 'the strong man of the East,' the terror of the Tartar, before the wind of whose hand the rebel flies. Alreary the Footow of Foo-Chow-Foo has conferred upon him the honorary title of ' Cheen Chung,' leader in battle of one thousand men, and wearer of the mandarin's blue button. He is the favourite of our supreme head, the Heaven-conferred one, whose youth lives as the bamboo, green ten thousand years-Our EMperor.

"I have one sister living, Chen Yow Izn; she is wed and well; she is only six feet high.

"My mother lives (she who claims my first duties, with my prince; for who can serve his ruler who has been negligent in his duty to his parents?). She is of ordinary size; and thus her family stands : Chang Sou Gow the Brave, myself the Tall, and Metzoo my sister, the Domestic Jewel.

"As a boy, I resembled the young bamboo-tree, shooting up tall and slim. At the age of nine years I went to school, and since the age of twelve the classic 
aphorisms of the founders of our literature, Confucius and Mencius, have been the guide of my life; from them I have learned that 'the more talents are put in force, the more they will be developed,' and 'if something be not added to our knowledge every time a book is opened, we read in vain; that to strive is man's part, but to accomplish is Heaven's.'

"Two years ago the good Chang Tzing, my father, died. He had reached his sixty-fifth year, when Joss (the Divine Being) called him to be numbered with his forefathers."

The speech ended, Chang bowed again to the audience, and then majestically descending from the steps of his throne, caught up the little dwarf in his arms as he passed down the steps, and marched with him up and down the room, carrying him on his arm like a baby. Giants, I know from experience, are very unwilling to have their proper measurement taken by visitors, but I had made preparations for discovering Chang's pretty accurately. I ascertained, before going to the Egyptian Hall, to what height I could stretch my hat over my head, and a friend was provided with a piece of red tape, which he measured out as seven feet. As Chang passed us, my friend stood up in a chair, held up his tape, and I held up my hat, as near as we could to the level of the giant's head. On comparing notes we made out afterwards that Chang's real 
height was about seven feet three or four inches. He appeared, however, of much greater stature than this, for the thick Chinese clump shoes which he wore gave him another inch or inch and a half, and his mandarin cap also added greatly to his stature. His pig-tail was a magnificent specimen of its kind, and hung from its owner's back like the pennant from the main truck of a man-of-war. I expected every minute to see the little dwarf catch hold of it and swing himself up on the moving mountain, as a sailor swings himself on board ship by a dangling rope.

In vain do we look in Chang's printed autobiography for his height in feet and inches; all we learn is that " he was in height the nearest to the heavens of all other men." I fear Chang was wrong, for my friend M. Brice, the French giant, was some three or four inches higher; he grew considerably while he was in London.

Chang's physiognomy was decidedly pleasing, and he seemed a most intelligent young man.

The dwarf rejoiced in the name of Chung Mow: he was an active little fellow, and put one in mind of the pictures of Humpty Dumpty one sees represented in chilären's story-books as "sitting on a wall." Chung Mow was always laughing, and his great delight seemed to be to bend his right hand backwards, so that the back of the hand touched the wrist. This seemed to be his sole performance. 


\section{Ena etdaun}

MADAME

The ladies would probably like to know what Madame Chang was like. Well, in my humble opinion, she was decidedly good-looking, and, I will be bound to say, kind-hearted and good-natured. Her hair was brushed well back off the forehead, and she had, I observed, the good sense not to adopt the chignon fashion, a fashion which I was glad to see had not reached China. Her name was "King Foo," or the Honest Lily. She wore, as may be anticipated, no crinoline; but, nevertheless, her dress was so well put on that it looked graceful. (English ladies, take a hint!) She was an aristocrat, I believe, in her own country, for she had the tiny little feet we have heard and read so much of as being the mark of aristocratic ladies in China. Anxious to see the feet aforesaid, I stretched a point, and was rude enough to ask Madame Chang Fow to be good enough to show them to me. This she did with very good grace and great willingness to oblige. I measured my lady's shoe, and found it was just the length of an ordinary fore-finger. I am the greatest admirer of a lady's chaussure, particularly if the foot be small and well shaped; but I really thought " the honest lily's" feet a trifle too small, even for my taste.

The giant's wife was attended by a lady's-maid whose name is Ah Ying. I cannot say much for the beauty of the poor maid. Her features denoted honesty and good-nature itself, but her face was more like a comic 
mask than that of any ordinary lady's-maid. The giant's two attendants were respectively called Woo-KwanToon, and Ling Ah Look.

They were highly intelligent, clever-looking young men, and spoke English pretty fluently; altogether Chang, with his wife and suite, were well worthy of a visit. 


\section{GIANTS IN GENERAL.}

ONE of the giants I have had the pleasure of visiting, and also of privately entertaining, was a Spanish giant, exhibited some years since at the Cosmorama Rooms, in Regent-street. His name was Señor Joachim Eleizegue. He came from the Basque provinces of Spain, and his height was said to be 7 feet 10 inches. I regret much I did not take accurate measurements at the time, as I frequently saw him in private. His cousin happened to be a patient at St. George's Hospital at the time I was a student there, and the giant was in the habit of paying frequent visits to his relative, and greatly were the other patients astonished when he came stalking into the wards.

Among modern giants I must now mention the following: In the Royal College of Surgeons, Lincoln'sinn-fields, is the skeleton of a giant who in his day excited great wonder and curiosity; his name was O'Brian, or Byrne; he was commonly known by the title of "the Irish giant." 'This man was said to have c 2 
been 8 feet high. I have measured his skeleton carefully, and find it to be $92 \frac{3}{4}$ inches, as nearly as possible.*

His history, as quoted by the College catalogue from the Annual Register's Chronicle, June 1783, vol. xxxv. p. 209, is as follows: "In Cockspur-street, Charingcross, died Mr. Charles Byrne, the famous Irish giant, whose death was said to have been precipitated by excessive drinking, but more particularly by the late loss of almost all his property, which he had simply invested in a single Bank of England note for 700l."

I hear he hid his note in the fireplace in summertime, and somebody lighted the fire and burnt the poor giant's hard earnings. I think it was old Mr. Cliff who told me this.

The limbs in O'Brian's skeleton are well-proportioned, but he must have been "in-kneed," and the arms are relatively shorter than the legs.

We have at the College a portrait of this O'Brian, and it appears that his visitors made the same personal comparisons with the giant in 1783 as the visitors of the present day do when they give M. Brice a call; for in this old drawing of O'Brian's soirée are represented, a little doctor (my antitype, I suppose)

* Mr. Cliff told me how this skeleton was procured, or rather purloined, but the story might not please some of my readers. A pair of O'Brian's stockings are, I believe, in the Museum at Bristol. 
perched high on a chair measuring his chest; a Life Guardsman (of the period) standing on tiptoe under his arm, and a good-looking young lady showing her pretty "tiny silken-sandal'd" foot by the side of the giant's, the comparison being greatly in favour of the lady's foot, as far as beauty went.

We have also at the College casts of the hands of Patrick Cotter, the Irish giant, whose height was 8 feet $7 \frac{1}{2}$ inches; of Mr. Louis Frenz, whose height was 7 feet 4 inches; and of the hands of a Lapland giant, and of an English giant, named Bradley.

By the kindness of Mr. John Busby, of Darfield, Barnsley, I am enabled to publish an account of the last-named giant given me by his brother :-

“Manchester, 20th June, 1862.

"Dear Sir,-In reply to your letter of yesterday, I have much pleasure in giving you all the information I can respecting my late brother William. He was born at Market Weighton, in the East Riding of Yorkshire, on the 10th February, 1787, and died 30th May, 1820. When nineteen years of age, he was 7 feet 8 inches, and weighed 27 stone; he grew another inch, which made 7 feet 9 . I have his shoe, which is 15 inches long by $5 \frac{1}{2}$ wide; walking-stick 49 inches long; his crutch, which he had made a short time before his death, 5 feet 10 inches; his trousers 5 feet 8 long; 
stockings 3 feet 9 inches from the toe to the top. My father and mother had thirteen of us, and none higher than 5 feet 10 . My father was about 5 feet $9 \frac{1}{2} ;$ my mother of the middle size. I never heard of any one of any branch of my grandfather's family that was above the ordinary size. My brother took no ale, porter, wine, or spirituous liquor; his drink was tea, milk, and water. He was very active in his youth, and worked in my father's fields, and was an excellent judge of horses. When he exhibited himself in the principal towns in England, Mr. David Waddington, late M.P., the Railway Director, knew him well. His mother was born at the same place. He was interred in Market Weighton Church, and I put up a marble slab to his memory. My parents having a large family, I was put 'prentice to a draper in Hull before I was twelve years of age, so that I really forget the colour of his eyes or hair. When he was eleven years old, he weighed 11 stone. I believe I have given you all the information I possess, and I hope it may be of service to you, although a stranger to me.

$$
\begin{gathered}
\text { "I remain, dear Sir, } \\
\text { "Yours, } \\
\text { "R. BradLeY." }
\end{gathered}
$$

Close to O'Brian's skeleton, stands that of a man who, not many years ago, served at the bar of the Lion and 
Ball, in Red Lion-street, London. He was called "the American giant." The height of the skeleton, by measurement, is 6 feet 9 inches. We have also at the College the skeleton and coffin-plate of Jonathan Wild, the celebrated thief-taker, but he was a little man, anything but a giant.

About the time that M. Brice was in London, the Irish giant, Murphy, died of small-pox at Marseilles. He was twenty-six years of age, about twenty-four stone in weight, and (it is said) was within a few inches of 9 feet high. He was a native of Killowen, near Rostrevor. He began life as a labourer at the Liverpool docks, but soon obtained a situation as a waiter at an hotel, where his size and agreeable manners helped to bring custom to the house. He then took to exhibiting himself regularly, and made a little fortune.

Of other giants I have the following records. The heights given of some of these men I think must be exaggerated.

On a tombstone in the churchyard of Calverley, in Yorkshire, is an inscription to the memory of "Benjamin, son of John Cromach, who died 25th September, 1826, aged twenty-five years," who required a coffin 7 feet 11 inches long. Again, in 1572, Del Rio saw a Piedmontese more than 9 feet in stature. Julius Scaliger describes a giant he saw at Milan lying upon two beds placed end to end. Gasper Bauhin cites a Swiss of 
8 feet. A Swede, one of the body-guard of the King of Prussia, was $8 \frac{1}{2}$ feet; and Vanderbrook saw a black man, a Congo, 9 feet high. Berkeley, the celebrated Bishop of Cloyne, was of opinion that he could raise up by artificial means a rival to $\mathrm{Og}$ and Goliath. He tried the experiment on a lad named Macgrath. The lad waxed taller and taller, and at length was carried all over Europe as a show. Just, however, as he had reached the age of twenty, and the stature of 7 feet 8 inches, according to the "London Chronicle" of 1760, p. 506 , the poor giant died.

In the year 1684 was exhibited in public, at Oxford, Edmund Melloon (born at Port Leicester, in Ireland); he was nineteen years of age, and was 7 feet 6 inches high; not so tall as M. Brice; his finger was $6 \frac{3}{4}$ inches long, span 14 inches.

In the year 1682 was exhibited, at Dublin, another giant. His father was in no way remarkable for his height, and his mother was of a more than ordinarily low stature. When he stood on the bare ground, with his shoes off, he measured full 7 feet 7 inches.

At Madame Tussaud's Exhibition, in Baker-street, there is a wax model of Loushkin, the Russian giant, "the tallest man that has ever lived in modern days, measuring 8 feet 5 inches high, dressed in his military costume as drum-major of the Imperial Regiment of Guards, Preobrajenskey." In the "Chamber of Horrors" 
is a cast of the thigh-bone of this giant, and also a model of his hand, \&c. By the kindness of the manager of this exhibition, I have received the following particulars:-

"Exhibition, Baker-street.

"Sir, - The casts of the giant's thigh-bone and hand were brought over by the Chevalier Le Molt, who had permission from the Emperor Nicholas to do so. To the best of Mr. Tussaud's recollection, the Giant died at the age of 33 or 34 , was married, and had one child, for whom the Emperor stood godfather. $\mathrm{He}$ served in the wars of Circassia with much honour, and received three military medals now in the possession of Messrs. Tussaud. On the late occasion of a visit by the Grand Duke Constantine, he immediately recognized him, and considered him a very good likeness.

"I have the honour to be, Sir,

"Your very obedient servant,

"F. T. Buckland, Esq."

"W. C. O'Brien.

When my late lamented friend, Dr. Gentzik, of Vienra, was in England, I showed him the cast of M. Brice's hand, in my possession. He informed me that there were some gigantic human bones in the Museum at Vienna, \&c. I immediately wrote to Professor Jos. Hyrtl, who very kindly sent me the following information :- 
"Sir,-I send you the measurements of the giant bones belonging to the anatomical museum under my care, together with what information I could pick up about the individual who was the bearer of them.

"In the latter half of the 18th century, the buryingplace surrounding St. Stephen's Cathedral was cleared out by order of the Emperor Joseph II. An immense quantity of bones were conveyed to the churchyards of the suburbs. A medical officer was ordered to inspect them, and to collect pathological specimens. A cartload of such was brought to the University, where they were put up in the anatomical museum. The most interesting among them are the giant bones in question : os innominatum, femur and tibia. Comparing the length of these bones with that of the same in an individual of known length, it is but an easy reckoning that our giant was a very young man, somewhat above 8 feet 6 inches in height. No other known giants attained such an enormous development, viz. the great Tonas, in the Museum of Berlin, a similar skeleton in the Museum of Marburg, and the famous O'Brian in the Hunterian collection.

"The Professor of Anatomy, thirty years ago, Dr. Mayer, told me repeatedly he had heard from his grandfather, that in the time of the latter there was in Vienna a story, very common, of the big Hayduk, in the service of Count Hunyady. This Hayduk (an inferior kind of body-guard of Hungarian magnates) was ori- 
ginally a Turk in the army which besieged Vienna in the year 1683. During a valiant sally of the armed citizens he was badly wounded and made prisoner. The fathers of the Franciscan convent in the town took care of him, and succeeded in converting the poor fellow to Christianity. The above Count, who probably was also a curiosity hunter, fond of giants, enlisted the re-convalescent convert as his Hayduk, and let him officiate as porter to his palace in Vienna. The house bore for a long time the nickname, 'To the big Hayduk, and when there was wanted a comparison with somewhat very great, the 'big Hayduk' found his way to the mouth of every man in Vienna. So far goes Professor Mayer, who took it for granted that the astonishing remnants of the giant skeleton are those of the 'big Hayduk.' Relata refero.

"Your very obedient servant,

"Vienna, Sept. 30th, 1862."

"Jos. Hrrtu.

With reference to the discovery of gigantic human skeletons, Mr. Bartlett tells me the following curious and interesting story:--

An Irish labourer once told him that he had discovered the skeleton of a giant in an Irish bog; he described it as placed on its back; the backbone, the legs and arms were, he stated, quite perfect, and also that, in his opinion, these bones must have been the remains of a person not less than 17 feet high. 
Mr. Bartlett, of course, rather laughed at the story, but, being a wise man, determined to go deeper into the matter, and cross-examined the Irish labourer very closely; the man was positive about the story, so positive indeed that it was quite evident he was telling no lies. Mr. Bartlett at last ascertained that this skeleton was that of an ancient Irish elk (Cervus megaceros): the head was missing, but the bones happening to be placed flat on the ground in the manner that a human skeleton would naturally assume, they resembled so much (to the uneducated eye) the bones of a gigantic specimen of the human subject, that the mistake is almost pardonable.

This is a good lesson, always to inquire into stcries; however improbable they may appear at first sight.

I cannot help placing with the above a most remarkable instance of a discovery of human bones, which might, if found by anyone but a scientific observer, have been described as gian's bones. Professor James D. Forbes thus writes: "We found (among the precipices of Mont Colton) the remains of the bones and skins of two chamois, and near them the complete bones of a man. The latter were arranged in a very singular manner, nearly the whole skeleton being there in detached bones, laid in order along the ice; the skull lowest, next the arms and ribs, and finally the bones of the pelvis, legs and feet disposed along the glacier, so that the distance 
between the head and feet might be five yards; a disposition certainly arising from some natural cause not very easy to assign."

The disposition of these bones must of course be dependent upon the movement of the ice blocks forming the glacier upon which the bones were placed: if Professor Forbes cannot explain it, it would be presumptuous in me to make the attempt.

Though authentic accounts of giants in the flesh are not very common, we find instances innumerable on record of the bones and skeletons of giants having been found buried in the earth. Some labourers who were digging gravel in front of St. John's College, Oxford, discovered and trundled off to my father at Christ Church a wheelbarrow full of " giants' bones," which he immediately decided to be the bones of fossil elephants. The men were ultimately persuaded into this belief, but they accounted for the presence of the elephant, by coming to the conclusion that the elephant whose bones they found must have been one that died in Wombwell's menagerie, though no one of the company could "call to mind" such an event ever having happened.

These "giants" bones" are and have been found and talked about by all nations; and when the rude inhabitants of Siberia discovered the celebrated fossil elephant in the frozen earth, they called it the "mammoth, or animal of the earth," and believed the 
remains were those of a gigantic animal that was still living beneath the surface of the earth. Many accounts are given by ancient authors, such as Kircher and others, not "of gigantic bones only, but of vastly gigantic men found buried underground, or in the hollow caverns of mountains." Of these a learned author, writing in 1722, says :- "Remains, such I mean as are truly bone (for some are only natural petrifactions and lapides sui generis), were bones belonging to some of the biggest quadrupeds, as elephants, or some of the largest sort of fishes of the whale kind; and I am persuaded that the large tooth mentioned by $\mathrm{Ol}$. Wormius was nothing else than the tooth of the Cetus dentatus or spermaceti whale."

All this I fully endorse. It is a curious passage, and one of the first that began to throw light upon the popular legends and stories of former days, when science was yet young, and exhibitions of giants' bones were not uncommon. In 1721, for example, the hand of a giant was publicly shown for money; this hand being, according to the author above quoted, "the bones of the fore fin of a porpess or small whale artificially joyned together." Here, then, is a good hint for an English Barnum; for the bones of the fin of a porpoise or whale, when the skin has been removed, marvellously resemble in appearance and shape those in the human hand. 
Even at the present day the belief in bones of giants, dug out of the earth, is by no means extinct, for a gen tleman sent me a tooth of a fossil horse, when M. Brice was in London, and asked if it was not a giant's tooth. I showed it to my friend Brice, the French giant, and we had a hearty laugh when we made the comparison of the horse's tooth with one of his own.

According to an ancient scientific work, in the "medicine school" at Leyden is a prodigious os frontis or frontal bone of a giant, measuring nine inches transversely, in the convex way twelve inches. A figure is given of this bone alongside that of a man of ordinary stature. After giving many details, the describer of this bone goes on to say, "whence it must follow that the man to whom this bone belonged was more than twice the height that men usually are, according to the common course of nature-that is, more than eleven or twelve feet high."

Now, here is a difficulty to be overcome. Upon carefully reading the above account, and examining the plate with accuracy, I have no hesitation in granting the fact of the bone in question being human, and of an extraordinary size; but at the same time, I conceive it to be the bone of some person who had been afflicted with chronic hydrocephalus, or water on the brain, and this disease had caused the bones of the skull to assume the proportions it presented. That persons afflicted 
with this disease will live for several years, I have no doubt, as I once paid a penny to a showman to see such a person, aged about fourteen years. In this case the head was gigantic, the body attenuated and shrivelled up. The skull of this person would have made a famous giant's skull. If this is not evidence enough to explain the nature of the supposed giant's skull, I adduce the evidence of but yesterday; for Mr. C. E. Harle has of late occupied himself in measuring with tape the external dimensions, and with dry sand the internal capacities, of most of the abnormal skulls in the College of Surgeons. He kindly reports to me: "I am certain that the skull of the giant O'Brian is of about the same capacity only as that of the individual of ordinary size that stands by his side. From all that I could collect from repeated examinations of very many skulls from nations all over the world, I came to the conclusion that the size of the skull did not, for certain, indicate the stature of the man."

In sacred Scripture we find many accounts of giants, and the following are some of the principal expressions made use of. Thus we read:- "There were giants in the earth;" "We saw giants, the sons of Anak ;" "Og, King of Bashan, remained of the remnant of giants ;" "Bashan, called the Land of Giants;" "The lot of Judah at the Valley of Giants," \&c. \&c. The chief of these ancient giants were-Og, the King 
of Bashan, and Goliath of Gath. Of the height of the latter, viz. 6 cubits and a span, there has been great dispute; one account making him to have been 10 feet 5 inches, another 9 feet only; while Bishop Cumberland (in his "Jewish Weights and Measures") makes him to have been above 11 feet.

Mr. W. Walker has kindly sent me the following note :-

"By our present measurements, 1 cubit $=22$ inches, 1 span $=11$ inches. The height of Goliath of Gath being 6 cubits and 1 span, he was consequently, according to our present measurements, 143 inches in height, or 11 feet 11 inches."

As to the antediluvian giants, some commentators have gone so far as to say that these "Nephilim" or giants were not so much giants in physical stature as great atheists and monsters of impiety, rapine, and all wickedness. "Anyhow," as says the learned Dr. Derham, in his "Physico-Theology," "be the matter as it will, it is very manifest that in both these places (the giants before the flood, and the giants seen by the Israelitish spies) giants are spoken of as rarities and wonders of the age, not of the common stature."

I cannot conclude these remarks without stating that I do not believe we of the present race are smaller than men of ancient times, be they post or ante-diluvians;

SER. III.-VOL. II. 
and I would feel much obliged if any readers of this book would kindly forward me any accounts of Giants they may happen to have, as the information on this point is widely difftised, and has not as yet, I believe, been ever hitherto systematically collected.*

Mr. Edward Simpson kindly sent me the following notes on giants :-

" 12 Limerston-street, Chelsea, "June 13th, 1862.

"My dear Sir,-I have just been reading your account of giants in 'The Field,' and as you requested further information on the subject, I send you a little that I have gleaned from various sources. In the 'Phil. Trans.' vol. xxii. there is an essay of some length on giants by Dr. Molyneux. He refers largely to the gigantic frontal bone in the 'Medicine School' of Leyden, and considers that it may possibly have

* Female giants or giantesses are still more scarce: the only one I ever saw was a Polish giantess. I found the giantess, in the spring of 1863, at Sarile House, Leicester-square (opposite to where the Great Globe formerly stood). She called herself the Countess Lodoiska. She was a remarkably fine young woman, of about twenty years of age, and of a pleasing appearance and manner, and according to the handbill, "she is 7 feet in height, weighs $270 \mathrm{lb}$., and can without difficulty lift $160 \mathrm{lb}$. or $170 \mathrm{lb}$. with one hand." Considering her great stature, she was not clumsy or inelegant-looking. She was a native of Warsaw, and her parents and family, I am informed, did not exceed the stature of ordinary men. 
been brought by some of the 'trading Hollanders as a natural curiosity and proper sample of some huge gigantic man met with in some of their voyages into America.' He then gives instances of other giants, and says, "In Flanders and Germany these men are usually of a larger size, and their bodies of a grosser make than with us. We meet with examples that have exceeded the stature of Edmund Malone of Portlester several feet. Isband Diemerbroect tells us that he saw himself at Utrecht, in the year 1665, a man eight feet and a half high, all his limbs well shaped, and his strength proportionable to his height; he was born at Schoonhoven, in Holland, of parents of an ordinary stature. Mr. Ray, in his Travels, mentions this very man, and that he saw him in Bruges, in Flanders. But that eminent physician and learned antiquary of the last age, Johannes Goropius Becanus, who lived in Flanders, has left recorded several instances of this kind yet more remarkable, and that were of his own knowledge too; for he says he saw himself a youth almost nine feet high, a man near ten feet high, and a woman that was quite ten feet in height. . . Andreas Thevet, the famous voyager and cosmographer to Henry III., King of France and Poland, in his description of South America, printed at Paris 1575 , has a passage so satisfactory on this point, and related with such particularly convincing 
circumstances, all of his own knowledge, that I could not omit setting them down at large. Here he tells us that 'being himself on the coast of Affrick, in the territory of Arguin, for three weeks together, he chanced to meet with a rich Spanish merchant who had somewhile before suffered shipwrack by a storm, as he touched at that place on his return homewards from the South America; but though he had lost his ship, the greatest part of the merchandize, and most of his men, yet he luckily saved a coffer, wherein he had carefully preserved the skull and bones of an American giant he had brought along with him from that country, who was eleven foot and five inches in height, and dyed in the year 1559. These bones he showed to Monsieur Thevet, who was so curious that he took the measures of the most principal of them, and he expresses himself on this occasion in these words (Anglicè) : A very marvellous thing, to which I could scarce have given any credit if I had not seen it myself; inasmuch as the kones of the leg measured full three foot four inches in length, and the skull was three foot one inch about!' At the close of the essay, Dr. Molyneux says that it is probable that $\mathrm{Og}$, King of Bashan, was not taller than the giant of the 'Medicine School,' Leyden. For, taking the length of the cubit as one foot six inches, and the length of Og's bed as nine cubits (Deut. iii. 7), he adds: ' he cannot imagine 
but that his bed must of necessity have been much larger than his body; and the least allowance we can make for the overplus is the space of nine inches above his head and as much below his feet; and if we make this deduction, it will follow he was not above twelve foot high.' Rather an original plan for ascertaining a giant's height !

"It appears to me very clear, as you observe, that the size of the skull is no criterion of the height of the individual; but in a letter to Sir Hans Sloane in 173̄, Mr. Klein, of Dantzic, gives the dimensions of a large bone (os bregma) of a skull, and taking and comparing it with others, he professes to be able to determine the height of another man, the size of the same bone being known. In the first-mentioned one the height of the head, from the chin to the crown, was 20 inches, the breadth about the temples 12 inches, the height of the os bregma 9 inches (English), and breadth 7 inches. By taking eight different heights of heads according to the rules of drawing, he computed the height of the man to have been 13 feet 4 inches. And having procured another os bregma, the height of which was $5 \frac{6}{6}$ inches and breadth 5 inches, with the assistance of a mathematical friend he determined the height of the man to have been 9 feet. The methods by which this result was obtained are given in full in Latin in 'Phil. Trans.' vol. xli. and in English in 
the letter alluded to. (See Ayscough's MSS., British Museum, No. 4,433, p. 107.) In the 'Phil. Trans.' vol. xxiv. mention is made of a skeleton 'of a humane body 9 foot long,' found in a stone coffin near Repton in Derbyshire in the year 1686. The skull was given to the Master of the Free Grammar School, but it was lost. No other dimensions are given.

" 'In January 1613, some masons digging near the ruins of a castle in Dauphiné, in a field which (by tradition) had long been called the giant's field, at the depth of 18 feet discovered a brick tomb 30 feet long, 12 feet wide, and 8 feet high, on which was a great stone with the words, "Theutobochus Rex," cut thereon. When the tomb was opened, they found a human skeleton entire, $25 \frac{1}{2}$ feet long, 10 feet wide across the shoulders, and 5 feet deep from the breast bone to the back. His teeth were about the size each of an ox's foot, and his shin-bone measured four feet !! !'

" Riolan, in 'Gigantologie,' disputes the measurement, and affirms that the bones belong to the elephant.

"In Ayscough's MSS. No. 4,438, p. 473, is an account of a gigantic child of Willingham. At the time it was written the child was two years and eleven months old, and was 3 feet 9 inches high; weight 4 stone. I expect this was only an overgrown child, and do not suppose that, when it was an adult (if it lived so long), it was much above the ordinary stature. 
"This is all I have acquired, and if of any service to you, you are perfectly welcome to do what you like with it.

$$
\begin{aligned}
& \text { "Yours sincerely, } \\
& \text { "EDward Simpson. }
\end{aligned}
$$

"F. T. Buckland, Esq.

"2nd Life Guards." 
THE

\section{FEMALE NONDESCRIPT JULIA PASTRANA, AND}

\section{EXHIBITIONS OF HUMAN MUMMIES, ETC.}

From giants I now proceed to other human Exhibitions. It is seldom, very seldom, that we are invited to see modern mummies, though ancient mummies are not very uncommon. In the month of February 1862, I received an invitation to examine a great natural curiosity described as "The Embalmed Nondescript," then being exhibited at 191 Piccadilly; I hastened to ascertain its nature.

Immediately on viewing it, I exclaimed, "Julia Pastrana!" "Yes, sir," said the proprietor of the exhibition; "it is Julia Pastrana." It may be remembered that some time ago (in 1857) a woman was exhibited in Regent-street, who was remarkable for the immense quantity of long black hair that grew on and about her face. An idea was also attempted to be promulgated that she was not altogether human; and the story was that she had been found among the tribe of Dregig 
Indians who are reported to inhabit various parts of New Mexico, Oregon, Utah, and the Gulf of Mexico.

Her name was Julia Pastrana. It appears that she died at Moscow, in Russia, and it was stated that she was embalmed there by Professor Suckaloff; and the mummy thus prepared was exhibited in 1862 .

Having had some experience in human mummies, I was exceedingly surprised at what I saw. The figure was dressed in the ordinary exhibition costume used in life, and placed erect upon the table. The limbs were by no means shrunken or contracted, the arms, chest, \&c. retaining their former roundness and wellformed appearance. The face was marvellous; exactly like an exceedingly good portrait in wax, but it was not formed of wax. The closest examination convinced me that it was the true skin, prepared in some wonderful way; the huge deformed lips and the squat nose remained exactly as in life : and the beard and luxuriant growth of soft black hair on and about the face were in no respect changed from their former appearance.

There was no unpleasantness, or disagreeable concomitant, about the figure; and it was almost difficult to imagine that the mummy was really that of a human being, and not an artificial model.

I well recollect seeing and speaking to this poor Julia Pastrana when in life. She was about four feet six 
inches in height; her eyes were deep black, and somewhat prominent, and their lids had long, thick eyelashes; her features were simply hideous on account of the profusion of hair growing on her forehead, and her black beard; but her figure was exceedingly good and graceful, and her tiny foot and well-turned ankle, bien chaussé, perfection itself. She had a sweet voice, great taste in music and dancing, and could speak three languages. She was very charitable, and gave largely to local institutions from her earnings. I believe that her true history was that she was simply a deformed Mexican Indian woman. As regards the history of the embalmment, there were some queer stories told.

Julia Pastrana being a Mexican, and being embalmed. by Europeans, is rather a singular coincidence, for in her own country the process of embalming is carried on, and this in a very curious manner. Mr. Louis Fraser tells me that the original Indians, who live at or near Zamora Equidor, on the east side of the Cordilleras, take trophies of their enemies in the following manner: they take the skin of the whole head (hair and all), and by some process, known only to themselves, reduce it to about the size of a man's fist; the hair, ears, and all are preserved (there is no bone left), and the features are like those of miniature Aztecs.

These curious little heads are carefully wrapped up 
and preserved over the fireplace; they are much prized, and on no account are parted with to strangers. A specimen of this kind was exhibited in the Exhibition of 1862. I was very anxious to purchase it, but the owner asked only 300l. for it; he afterwards came down, and reduced his price considerably. I was exceedingly sorry I could not afford to buy it; it certainly was a gem of a head; I should be curious to know where it ultimately went.

In my first series of " Curiosities of Natural History," I gave an account of an extibition of a modern mummy from the Guano Islands; the name of the man who was preserved in the guano was "Christopher Toledo ;" since then I have seen, in a penny show in the streets of Elinburgh, another guano mummy, described in the handbill as follows :-

"This mummy was brought to Liverpool from Possession Island, western coast of Africa, by Captain Dunlop, in the schooner Echo, from Greenock.

"The hair, teeth, whiskers, moustaches, hair on legs, finger-nails, toe-nails, every part is correct as when alive, and is in a perfect state of preservation. Also will be shown the shirt, stockings, and blanket in which he was buried, and the board which marked his grave on the island, with the date of his interment.

"It is shown more to prove the preserving qualities 
of the guano than from any desire for emolument on the part of the proprietor." (?)

I examined this specimen carefully. On the board (which was made of oak) were rudely carved the words, "Peter Creed, 1790."

The proprietor was exceedingly proud of his mummy.

"There is not a scratch upon him," said he; " he is just as perfect in the back as he is in the front. He is as good as a pension to me as long as he sticks together, and what's good for him is good for me. I cleared $21 l$. in eleven nights with him (rather against the scientific sentiments of the handbill this). As for Christopher Toledo, I knows him well enough: he did well enough at fust, but he's all going to pieces now, he is ; he ain't no use as a scientific mummy now; the more's the luck for me as long as my Peter Creed holds together."

A friend of mine, who now commands a large trading steamer, brought back with him, about two years ago, as a speculation, three mummies from Egypt. Immediately on their arrival in London, he asked me to examine them. They were two males and a female, in a remarkably good state of preservation, the hair, nails, skin, \&c. being dry and hard like boards, and the features in two of the specimens distinctly visible. They did not appear even to have been wrapped in bandages, but to have been submitted to the process of embalming, 
and then allowed to dry. I fancied from their appearance that they had been embalmed by the ancient Egyptian priest-surgeons, after the following manner, as described by Herodotus as one of the least expensive methods of embalming: "They fill all the intestines with cedar oil, without either cutting into the abdomen or removing the viscera; then preventing the egress of the injected fluid, they salt the body for the fixed number of days, and at the end of that time they let out the cedar oil, the power of which is such that it brings out in it both the intestines and viscera; it consumes the flesh, and the skin and bones alone remain. This being done they return the body."

My friend described to me the various adventures and escapes he encountered in bringing over his specimens, it being very difficult to obtain mummies of any kind, now-a-days, in consequence of the Egyptian government having forbidden them to be taken out of the country.

Among other plans headopted to pass the authorities who came on board, he placed the three mummies in the berth where the sailors usually sleep, and covered them up with rugs, \&c., as though they were tired sailors taking a nap; and if I recollect rightly, he told me that a friend who was partner in the mummy venture lay down with them. 
When the officials came round, the partner pretended to wake up out of sleep, and, sitting up, yawned and rubbed his eyes as if half awake. The deceit answered capitally; the officials, thinking that the three mummies were only three tired sailors, did not examine further, and so they were passed.

In due time these mummies arrived at Liverpool, and the question arose as to how to sell them to the best advantage; so the owner put it all about the town that some wonderful mummies had just arrived, and were on board a ship in the docks. A paragraph even got into the local newspapers to the same effect, and this was just what they wanted; for a showman who had an exhibition in the town, reading the account in the newspaper, immediately came on board the ship, and made a bid for the mummies; the price tendered, however, was not high enough.

The next day the showman came again with a further offer, which, however, was not accepted. To make him more desirous of obtaining these curiosities, my friends found out where his show was situated, and for two or three evenings remained smoking their cigars about the show, and paid boys and idle people they found about the place a small fee to go to the door of the show and ask to "see the wonderful mummies which had just arrived." 
"We have not got them yet, sir," was the showman's answer.

"What? not got the mummies! never heard such a thing. No mummies! Can't possiblygo into the show," said the visitor.

The fact of so many people coming, night after night, so quickened the showman's appetite that he made a higher bid of several hundred pounds, which offer, foolishly, not being accepted, the owners brought the mummies up to London.

The last thing I heard of them was from my friend, who told me that he had left his mummies at his lodgings while he went on another voyage; when he returned, he found his landlord had got into trouble, and had pawned the three mummies for 10l. at some pawnbroker's by the Docks. Reader, if you are very anxious to have them, there may still be a chance of getting mummies cheap.

A curious case relative to mummies was, not many months ago, brought into the County Court, at Knaresborough, in Yorkshire. A gentleman was sued because he would not pay for a clock. It appears he bought a mummy-case for $5 l$., and had it converted into a handsome clock-case for his hall; a clock was put into it, but " it would not go," and shortly went as dead as the mummy which had formerly been deposited in it. Then 
came the lawsuit. The country folks said the clock would not go " because the ghost of the mummy haunted it." The learned judge took a different view, and decided that the clock was a bad one. I wonder if the clockmaker put up a "skeleton clock" in the mummycase?

Everybody has seen the mummies in the British Museum. The following was told me by a friend relative to them:-One day a sharp-witted Londoner was coming out of the Museum, when he saw a countrylooking visitor gaping up at the building, and evidently half afraid to go in.

"Is the Museum open to-day ?" said the countryman.

"Open to-day," said the Londoner ; "certainly not." "Why not?" said Johnny Rawbone.

"Why not? is it pussible that you have not heard the news? Why one of the mummies is dead. You can't go in to-day." *

* This may or may not be an old story; anyhow, I tell it as it was told to me. 


\section{THE WOOLLY WOMAN OF HAYTI.}

ABout the same time that Julia Pastrana was exhibited in London, I saw an advertisement that "The Woolly Woman of Hayti" had arrived in London. Now there are certain cases where "too much of a good thing" becomes a nuisance and a bore. The female sex, from time immemorial, have been entitled to the beauty and ornament which long hair affords to the human figure. But it is just possible for the hair to grow so long that it becomes a deformity; and "The Woolly Woman of Hayti" was a good illustration of this. When I paid my visit of inspection, I confess I was rather dissappointed to find, instead of a beautiful fair young creature, with long flowing silken hair (as represented in the handbill sent me), a poor shrivelled old woman, as black as a crow, with hair as crisp and as woolly as the covering of any ordinary sheep; nevertheless, I did the civil to her as well as I could, considering she speaks no language but her own, whatever that may be.

Her name was Antoinette, and she is said to have SER. III.-VOL. II. 
come from Hayti. Nothing is mentioned about this place, but it may be as well to remind the reader that Hayti is one of the great Antilles, or larger islands of the West Indies. What the aborigines of this place may be, I know not; anyhow, Madame Antoinette was, in my opinion, a negress, or a mulatto with much negro blood in her; she was fifty-eight years of age, and her hair did not begin to grow till about ten years before I saw her. It presented a long, thick, plaited mass of wool-like hair, which she allowed to hang down on her right side. It grew nearly entirely from the top of the head, the hair on the sides of the head not contributing much to the general stock, but rather forming independent hair-like fringes.

I measured the mass of hair carefully, and found it to be four feet eight inches long; it grew in a thick mass (fifteen inches in circumference) from the crown of the head, and then separated itself into numerous small cords, the thickness of packing-twine, and these cords again united to form literally ropes of greater or smaller dimensions. About the centre of its length, the hair, when spread out, was seven inches broad, and twelve inches in circumference as grasped by the hands. At its end, it terminated in rather abrupt and separate screws of hair, like a bunch of lace bobbins.

Antoinette obligingly coiled her hair up on her 
head, to show me her coiffure when in private. Thus placed, her hair formed a sugar-loaf cone of three turns and a half, measuring twenty-nine inches at its base and thirteen inches in height. The total weight of the hair was said to be four pounds, but I do not think it weighed as much as that; it appeared to be a genuine growth from the head, and from its very commencement to its end the fibre twisted itself tightly (corkscrew fashion) upon itself, rendering it elastic and springy when extended, as is the case with most negro hair. It was quite clean, and was carefully tended every day. No reason for this superabundant gift of nature can be given; anyhow, poor Antoinette ought to be much obliged to nature for her kindness in providing her with means of gaining a subsistence, such as it is.

My own idea about the actual character of this hair is, that it is a form of disease, called "plica polonica," a disease not uncommon among the Jews of Poland. The hair becomes matted thickly together, in fact, felts itself naturally. We have three specimens of plica polonica in the College of Surgeons, all three cases being in Europeans. I believe the case I have above described is simply plica polonica in a negress.

A modified form of this disease is often seen in animals, particularly in sheep-dogs, and in some kinds of long-eared pet dogs. 
I recollect an exhibition at the Egyptian Hall of "An Arctic Dog taken from an Iceberg." This was an ordinary dog-a poodle, if I recollect rightly - who had plica polonica very badly, the hair hanging down in thick pear-shaped festoons. The dog of course had never been on an iceberg, unless somebody put him on and took him off again.

The poor "Woolly Woman of Hayti" did not, I fear, make her fortune in London, and the beginning of her downfall was a squabble with M. Brice the giant, of whom I gave an account some few pages back. Brice had a sort of "Indian Temple" set apart for him at Cremorne Gardens, and he had it all to himself for a long time.

One day, on arriving at the gardens, he found preparations being made to divide his Temple in half, and he learnt that "La Femme aux longues Cheveux," or "The Woolly Woman of Hayti," was about to share his apartments. The giant was most indignant at this intrusion, and told the authorities that he would leave the place immediately if the intruder was not removed. Matters were settled in favour of his remaining undisturbed in his temple, and the poor "Woolly Woman of Hayti" took her departure, I believe, to Paris, where she was shown as the "Wild Woman of the Woods." This is the last I heard of her. 


\section{THE AUSTRALIAN FAT BOY.}

IN opposition to "The Woolly Woman of eighty," as the cockneys called her, there arrived in London "The Australian Fat Boy." There was no humbug about the name, for if ever there was a fat boy, this was the individual, and I would have backed him to be fatter than the "Fat Boy" in Pickwick, who has been the type of the species for many years past. The Fat Boy's name was William Abernethy, alias "Fat Billy," or "The Australian Marvel;" he was born of Scotch parents, at Sydney, New South Wales, on the 29th of November, 1848, and a copy of his register of baptism, certifying this, was shown. The following were his measurements: Weight, 23 stone; height, 5 feet 6 inches; round the shoulders, he measured 62 inches; round the waist, 57 inches; round the calf of the leg, 24 inches; round the thigh, 39 inches. " $\mathrm{He}$ was a very small child until about thirteen months old; he then commenced accumulating fat, and went on increasing until he attained his present development. He was very abstemious and temperate in his habits, and 
intelligent and lively in his disposition." I may say he looked the very picture of good-nature-most stout people are good tempered-and his temper seemed to correspond with his obesity. The growth of fat seems to increase rather than diminish annually, and if he continues to grow in height as well as in size, he bids fair to become a modern Daniel Lambert, and would do well to form a heading for Mr. Thorley when he invents a new kind of food to fatten bipeds as well as quadrupeds. Cases of enormously stout people, like "Fat Billy," - as this "Australian marvel " is familiarly called-are not very common, though they are sometimes seen at fairs. I wonder Mr. Banting does not try his hand at "leaning" one of these specimens.

The Fat Boy had seen some adventures and some "society" before his arrival in London, for I learned that he had lately formed one of a company, the proprietor of which exhibited some of the varieties of the human species, viz. this "Australian Billy," a whiteheaded albino, and a dwarf, fifty years old and not four feet high. The whole company, together with the master himself (a black man), all lived together, day and night, in a one-horse caravan. A nice sample of the varieties of the human race they must have made. 


\section{THE SPOTTED CHILD.}

I ALTWAYS go into caravan exhibitions at fairs, \&c. At the Windsor Fair, in 1861, I saw, hanging outside a show, a large picture of "The Spotted Child, to be seen alive." I paid my penny, but as the Spotted Child did not come in just at the moment, and I was in a hurry, I paid sixpence for an immediate and private view of the Spotted Child; and the woman who had charge of the show brought out from behind the curtain an exceedingly pretty little flaxen-haired, blue-eyed, English girl, dressed in ordinary costume, about six years old. I could see spots about her, but her mother soon showed me that her body, arms, and legs were all covered with spots of different shapes and sizes.

I examined these spots carefully with a pocket magnifying lens, and have no hesitation in saying that they were the result of no skin disease at all, which I thought before I saw the child might have been the case, but were simply the marks made by a strong solution of nitrate of silver which had stained the skin a jet black, and which showed up well on her white skin. I could 
perceive, with a magnifying glass, even the marks of the brush at the edges of the spots.

Ladies may like to know that the application of the nitrate of silver would not in any way hurt the child, and that they would soon wear off. The mother was an ingenious woman thus to turn her child to account without in any way injuring it. 


\section{THE NEW ZEALAND WARRIOR CHIEFS.}

There seems to be innate in the human mind a love to talk of the doings and sayings of its fellow-creatures. We find this in all societies and in all conditions of mankind. The more limited and defined the range of the observation of the talker, the more microscopic he or she becomes in the determination of the qualities, good or bad, of other folks. When, however, we take a large view of mankind, this passion for personal inquiry assumes a more important feature, for we pass at once into the science of ethnology. London, being as it were the centre of the civilized world, we who live therein often have the privileges of free intercourse with the various inhabitants of this great and wonderful world. We oftentimes have the opportunity of looking on the features of Chinese, Hindoos, Turks, Africans, Americans, Arabs, Mexicans, Esquimaux,*

* I well recollect obtaining my father's permission to ask to lunch at the Deanery, Westminster, three Esquimaux that were being exhibited in London. Their names were Tickaluck-too Huckbanjoe (and I forget the name of the third). They were nice, quiet, agreeable people, and were wonderfully struck with 
and other children of Shem, Ham, and Japhet; but it is rarely that we have a chance of shaking the hand of friendship with the aboriginal inhabitants of our antipodes-the Australian aborigines and the New Zealanders. It was with great pleasure, therefore, that I received, in July 1864, an invitation from Mr. Wilde, of the Alhambra, Leicester-square, to be present at the first public performance of the Maori warrior chiefs.

Before the New Zealanders came on the stage, I gained the following information about them. Their names (which are, I believe, their true names) and descriptions were as follows :-

TOMATI HAPIMANA WHARINAKI, a chief of great rank and influence of the Tawera tribe in the Bay of Plenty-ancestors very great warriors-a magistrate of New Zealand.

PAURO WHAKAHEKE, a chief of rank and influence of the Tawera tribe, Bay of Plenty-descended from a long line of ancestors, renowned for warlike deeds and great prowess in arms.

PENE TUTU, a chief of rank of the Negato Kahungugnu tribe, East Cape.

HENARIPIRI METE, half-caste-of the Ngapuhi tribe of Hokiangu-descended by his mother's side from ancestors of renown. His uncle is a magistrate of Hokiangu.

the Abbey. Among the monuments, that which most attracted their attention was the figure of a ship ; they also fell greatly in love with a marble anchor. I shall never forget their amazement and excessive delight when they first heard the organ's notes rolling along the aisles; the effect was very remarkable upon these poor but innocent people. 
RANGATIRA MOETARA, a young chief of great rank and influence of the Rarawa tribe of Kaitaia, Bay of Islands district. Descended from an illustrious line of ancestors. His uncle is at present a magistrate of his native district, and a man of great influence amongst his people.

APERAHAMA PUNGATURA, a young chief of the Four Ngatihinetu tribe, of great rank, and from the Waikato country, cousin to the Maori King, Potatatau II.

Being anxious to see somewhat of the world, they were about to make their travels through England and the Continent. They hoped by means of their performances to be enabled "to work their way," and if successful, to take back some golden trophies to their wives and children in New Zealand. They had also visited Australia, where they appeared in public at Melbourne.

When the curtain rose, we saw these fine specimens of the human race paraded before us. They wore their native dress, which consisted simply of a sort of kilt, their arms, chests, \&c., being without any ornament, save and except the tattoo marks worked into their skin.

They began their performance by the "launch of the war canoe," far different from the launch of one of our iron line-of-battle ships, but yet accompanied with such yells and eager cries as would make one dread an encounter with them in an open boat at sea, and likely enough to frighten any opponents ignorant of the use of firearms. Then followed a dance, which I understood 
to be "the Maori double war-dance;" that is to say, a dance not unlike the mummer's dance in England, only a great deal more vigorous, by means of which those who are about to fight work themselves up into a fit and proper state of courage and daring. So admirably, indeed, did they perform this part, that they really did work themselves up into such a state of excitement that my friend who was with me whispered quietly in my ear (we were close to the stage): "I say, friend doctor, we had better be off, for upon my word I expect these fellows' instincts will overcome their rationality; and if they do not 'raise the hair' of one of us, it will be a wonder, and a nice ornament the Bucklandian scalp would be for a New Zealand village pole."

However, on a given signal, they (to my friend's relief) sat down and turned on the steam to songsinging. Ladies, cease your melodious Italian air, your English and your Scotch ballads, and if you wish to cause a real sensation in your family circle, learn to play and sing the Maori song; perform it when next you go out, with its very peculiar action of trembling the hands one over the other in the air-the chorus of "Chip arrh, Wah ah harr, Ugh ah ug Ah ah yee ourahh," and its gesticulations of pity or defiance, as the sentiments of the words of the song suggest, and I think you really will make people stop talking even in the most crowded evening party. This song, I understood 
from Tomati Hapimana Wharinaki, who (having attended a missionary school in New Zealand) speaks English pretty well, was the Maori version of "God save the Queen." From what I heard of it, I do not think our own National Anthem need fear dethronement by the musicians of New Zealand.

Then followed Maori games of ball, and also Maori wrestling, in which the fine muscular development and snake-like agility of these well-built men was admirably displayed. Then came a wrestling match-a magnificent display of real genuine trial of strength of bone and muscle, man against man, power combined with activity, quickness of eye with gladiatorial ferocity. I should much like to see a match between the Cumberland wrestling champion and Henari Piri Mete, who managed to throw three opponents one after the other, having a drawn battle with the gigantic Aperahama Pungatura, who stands about 6 feet 2 inches in height.

The performance over, I was introduced to the Maoris one by one, and I was so much pleased with them that I invited them to lunch the next day at my house, in Albany-street. When they arrived, it was most strange to see how these men, but a few hours since fierce and warlike, were now as shy and timid as children. At their first introduction they did not feel at all at home, and, what was worse, I could only show my willingness to be agreeable to them by gesticulations and such signs 
as I thought would express my ideas. Conversation, under such circumstances, is not the most lively, and in the present instance was confined principally to one word, "kapai," which means "very good." My English friends whom I asked to meet the Maoris at lunch were in a somewhat similar condition. However, if we did not talk, some of us managed to eat, for the New Zealanders consumed fourteen pounds of roast beef in less than no time. When eating ceased, I bethought me of what was to be done to amuse my guests, so I sent off a message to Mr. Wareham (the well-known dealer in arms, weapons, old china, \&c.), to ask hin to bring, from his shop at the corner of St. Martin's-court, Leicester-square, everything he had from New Zealand: he kindly came up at once with a huge bundle of clubs, spears, paddles, knives, and weapons of all sorts. I stood at the head of the table and produced these one by one. When the article I showed my guests was of true New Zealand manufacture, they instantly recognized it, and stretched out their hands towards it with glee and a shout of joy. When the club or spear was not from New Zealand, they took no notice whatever of it. I also brought down an old and fine edition of Captain Cook's Voyages, and they examined the plates of New Zealand weapons, war canoes, \&c., with evident pleasure, conversing with each other about the prints, and evidently mentioning the facts and anecdotes which, 
alas! I could not understand any more than they could understand my questions about them. The figure of the big war canoe especially attracted their notice, and "kapai, kapai," was uttered simultaneously by all.

During lunch I had a capital chance of examining the tattoo marks, which they call in New Zealand "moko." The faces of Rangatira and of Pungatura were perfect models of tattooing, and would form capital patterns for ladies' crochet work. On the whole, I think the deepblue lines about the lips, face, and nose of Henari Piri Nete were the most elegantly designed and tastefully executed. Pungatura explained how the process of tattooing was done with a sharp instrument, a little hammer, and a series of tappings, by which the grooves were made. All the men had their ears bored-not little punctures such as we see in the ears of our belles at home, but great big holes that can be put to real service-sort of châtelaines, in fact-on to which any article, not too heavy, that will serve either for use or ornament may be attached. Only one of them, the above mentioned Henari, wore his earrings. These consisted of two long strips of black ribbon, and by way of a setting, to them were fastened two beautiful ivory-white sharks' teeth.

Much as you may laugh, ladies, I assure you these white sharks' teeth looked very pretty, and formed a -good contrast to the peculiar dark-brown colour of the 
skin. Ye brunettes, if you wish to show off your complexion, wear sharks' white teeth for earrings.

Seeing that I was much interested in tattooing, Pungatura, when I offered him a cigar and a light, called me aside to the window, and with a most serious face (for he was quite in earnest) whispered in broken English in my ear, "You good to me; me moko (tattoo) your face; me you tattoo beautiful like my friend Rangatira." I thanked him much for the compliment, but declined his services, though I confess I was greatly inclined to let him operate on my arm, just for the fun of the thing.

While entertaining these tattooed New Zealanders, I could not help thinking how fortunate it was that times were changed, and that we no longer knew New Zealand alone by the mummy heads of its inhabitants, but were able to welcome their whole bodies, with their heads safe and sound in their proper positions on those bodies. The head of a New Zealander, if it be well preserved and handsomely tattooed, is worth at the present time about five pounds; but these specimens of stuffed humanity are gradually getting very rare. In former times the New Zealanders used to murder one another in order' to sell the heads of the victims to captains of ships. If the murdered man was not tattooed enough before death, the face was further ornamented_afterwards. The demand for this strange. 
kind of saleable goods has luckily become less, and the heads are therefore rarely seen except in museums which have been established many years.

The late Dr. Kidd, Regius Professor of Medicine at Oxford, had in the Anatomical Museum at Christ Church the heads of two New Zealanders, one engraved before, the other after death; and he pointed out to his class the difference, viz. that in the former (where the tattoo had taken place after death) the markings presented deep grooves like the scorings on a leg of pork before it is cooked, because the cuts remained just as they were made, the skin not growing over them; whereas the latter (where the tattoo had taken place before death) presented the ridges filled up and covered over with skin, the skin having had time to grow over the cuts after the operation had been performed.

The luncheon over (hearing that the New Zealanders are very fond of public speaking), I called for silence, and made them a speech, in which I told them how glad we were to see and to welcome them so far from their Maori homes, though it was at the same time a satisfaction to know that they were not the Macaulay New Zealanders, who one of these days are to gaze on the ruins of the great metropolis from London Bridge.

Thanks were returned by one of the party, familiarly known by the name of "Dicky;" and friend Dicky SER. III.-VOL. II. 
made his speech very well, his actions showing that he really meant what he said.

After lunch we adjourned upstairs to smoke; the tallest of the men put on the helmet, cuirass, and sword, of one of the officers of the 2nd Life Guards, and a splendid fellow this fine savage looked in Her Majesty's uniform. All went well for a time, but at last a catastrophe suddenly took place. I was showing my guests a harpoon, a picture of a sperm whale, some stone hatchets, \&c., from New Zealand, when I thought of a present I had just received, and opened a box containing some thirty-six live slow-worms, and placed one on the floor.

In an instant the whole scene was changed; the New Zealanders in a moment threw off their civilized manners, and were instantly savages again; they looked first at me and then at the slow-worm on the floor, and then uttering loud yells and a sound which I conceived to be the war-cry, the whole party went helter-skelter down the stairs back into the dining-room. The window was open, and away they went into the little garden at the back of the house like a pack of hounds breaking cover, filling the air with what the French sportsman calls " tapage d'enfer."

When outside the window, they spread themselves, to my horror, all over the neighbours' gardens, taking the low fences like deer: two of them saw a parlour 
window open on to the garden, some few houses above mine, and ran to it for refuge. In the window, quietly sitting at her afternoon work, was a dear peaceable old lady. The flying Maoris heeded her not, but rushed straight for the window. The poor old lady, looking.up suddenly, saw a couple of gigantic savages, with their faces tattooed, screaming and yelling as they charged down on her : the good old thing was frightened out of her senses at this unwonted inburst of New Zealand savages into her garden in Albany Street, and was nearly frightened out of her life; and upon my word I do not wonder at it. I was very sorry that this should have happened, and was delighted when I saw the New Zealanders come away from the old lady's window, and endeavour to clamber over the wall into the Regent's Park. The Englishman who was with them was terribly afraid they would get over the wall, for if they had succeeded, he would have had some difficulty in getting them together again. However, after a time, my fierce visitors became quieter; the interpreter went out into the garden and told them that I meant no harm, and that they must come back at once; so back they came, looking very suspiciously at me, for they imagined that I had got them into a trap, and wished to injure them with the snake-like slow-worm. I had no idea, of course, that the presence of this little harmless reptile would in any way be unpleasant to them, or I 
never should have dreamt of showing it to them. I imagined, at the time, that their fright proceeded from their taking the slow-worm to be a poisonous and deadly snake. I stated this in the "Field," but I afterwards learned that I was mistaken.

The account of my entertainment to the New Zealanders was printed in the "Field," and a copy of this paper went to New Zealand. Some months afterwards, W. L. Willis, 14th Regiment, dating from Wellington, New Zealand, gave us the following information :-

"The fact is, there are no snakes in New Zealand, and (with the exception of one spider, called Katipo, and an animal resembling a grasshopper, which lives in decayed wood, called Waeta) I believe none of the animals are poisonous. The real reason that the Maoris feared the slow-worms at Mr. Buckland's party was, that in their religion (and though the men may call themselves Christians, it must not be imagined that their old superstitions are by any means obliterated) all reptiles and lizards, \&c., are, whether harmless or not, ' Ngarara,' an expression which conveys to the Maori mind the idea of the incarnation of the deity, powerful for evil. It was the resemblance of the slow-worms to lizards, and the consequent dread of them as 'Ngarara,' that caused the Maoris to flee from them."

When the New Zealanders had made friends again with me, after the little difficulty about the slow-worm, we 
had another glass of wine and a pipe of peace together, and then adjourned to the Zoological Gardens, where my friend Mr. Bartlett, the superintendent, very kindly undertook to accompany my newly-made friends round the gardens. It was most interesting to see how these men, who have no mammal in their island bigger than a pig or a rat-horses, of course, where Europeans have colonized-were amazed at what they saw. They gazed with wonder at the camels, they were silent before the lions, and were half-frightened at the elephant. We persuaded them to ride upon the elephant, Mr. Bartlett going up with them, and much they seemed to enjoy the ride when once up.

We then examined the zebra, with which they were highly delighted. Our friends remarked that the zebra had tattooed his face. "He moko him face," said they. This was a good idea, as a zebra's stripes are not unlike tattoo marks. They afterwards looked at the rhinoceros, which they all agreed was a "big porka." "Big porka, me eat him."

We did not tell them what we were going to show them next, as we wished to try an experiment, and possibly gain some information as regards the natural history products of New Zealand. Mr. Bartlett caused the "Kiwi," or apterix, from New Zealand, to be turned out of his house. The Maoris recognized him in a moment: "He kiwi, kiwi; he good eat, better than 
fowl and turkey; he make good pie; we hunt him at night with dogs in our country. Your bird very little ; New Zealand kiwi much bigger; he kick hard with him leg."

Of course Mr. Bartlett and myself followed this account up with leading questions about the Dinornis. "Ah! moa bird; he big bird, bigger than that much (pointing to the ostrich). He come out at night like kiwi; he very difficult catch. My father see one once. Moa bird very scarce. Plenty him bones in river. Feathers moa bird in houses New Zealand." And this was about all we could learn of the moa. All the New Zealand party seemed to know the name "moa bird" well enough, and we were much pleased to get even as little information as this.

Time was pressing, and the Maoris were obliged to leave the gardens. We parted the best of friends, with the words "kapai, kapai," and a hearty shake of the hand all round.

I would beg to refer the reader to the Appendix, where he will find some notes of mine relative to this moa bird. 


\section{WANDERING MOUNTEBANKS.}

There are many semi-gratuitous exhibitions to be seen in the London streets, and at race-courses, \&c.; in fact, to myself, at many public spectacles, the spectators are to me themselves the greatest show. As Pope has it, translating Horace's allusion to the Roman sports-

"Let bear or elephant be e'er so white, The people, sure the people, are the sight."

I never neglect any opportunity of learning how some of the more needy of the mixed multitude endeavour to gain a scanty living, and transfer a few coins from the pockets of their richer fellows to their own.

The Epsom Downs, on Derby-day especially, seem to be the assembling point of all the peripatetic performers for a hundred miles round; real vagabonds some of them; honest kindly folks others; but all anxious to make a harvest. I was gazing one Derby-day on the crowd, from the top of the 2nd Life Guards' drag, when I was startled by a sudden and most hideous noise at 
my shoulder. Turning round, I beheld a man with an enormous shock of wool-like hair, stuck out from his head like a New Mexican savage, who, holding his nose with his fingers, was producing, with marvellous intonation, the most unmusical bray of a donkey; he must have practised it for years, for it was louder and more discordant than the real donkey's voice, and the prolonged screech at the end caused many bystanders to put their hands to their ears in sheer despair.

Then a pale-looking man, with his hair cut quite short, and clad in a tight-fitting jersey, which seemed quite wet through, deposited by the door of the drag a washing-tub nearly half full of water. I could not imagine what he was going to do, till he threw into the tub a small coin, meant as a decoy for other contributions, and, pulling his short hair, said, "American diver, if you please, sir." By dint of practice, he had acquired skill in fishing up coins with his lips; a performance not interesting to see, and anything but conducive to the longevity of the diver, whose head was sometimes submerged a painfully long time.

Next came a man, grim, dirty, and stupid, carrying a model of a coal-mine, and a placard on his hat, stating that he had been blown up by fire-damp, and had been disabled for future active work; the coal-mine was a little the worse for wear, and well polished at the corners, showing that he had lugged it about many a hundred 
miles in search of coppers, and here and there a stray bit of silver.

Following him came a man with an electric machine, and he gave shocks at the rate of a penny a shock, or three shocks for twopence; he did not get many customers at the latter tariff, but one pocket of his old tail-coat seemed pretty heavy with subscriptions to this scientific experimental philosopher.

Bang! what's that? surely revolvers are not allowed to be fired in this crowd! there is the smoke, too, behind yonder carriage; there is no commotion, but I certainly heard a pistol go off. I will go and see what it was. Ah, master Jacko, it's you, is it? you too have come down, fiddle, bell, sword, musket and allfrom London. Little you care for sight-seeing, you clever little caricature of humanity; and I see you don't seem anxious to fire the gun again, and your sham fight with your master, as you hop round and round your board, sword in hand, is not so energetic as I have seen it !

"The fire-eater, or the celebrated living salamander," growled out a deep voice close under the wheel of the drag, while I was speaking to a friend. "Light up, Jim," said the wild-looking owner of the voice aforesaid. Jim forthwith put a penny tin plate on the ground, and pulling some dirty tow out of one pocket, and some powdered resin out of the other, placed them both on 
the plate, and lighted them up according to orders. The living salamander coolly began cutting up his smoking and indigestible meal with a knife and fork, and, when sufficiently comminuted, ate it all up, bit by bit, hot, blazing, and emitting fumes of resin ! Why he did not burn his lips and mouth, I know not, and where he stowed it all away, I am amazed to understand; certain it is, he brought none of it out again in my presence; he must have a pouch like a pelican somewhere in his throat, for immediately after his fiery meal he devoured a hatful of shreds of paper, and then, making sundry grimaces, pulled out of his mouth a long roll of party-coloured paper, a yard and a half long, coiled up in a beautiful tapering cone.

What an apparition! surely it is a ghost making its way towards me among the wheels of the carriages. Not a word nor a sound does it utter, and how carefully it glides along. Poor ghost, you must indeed be hungry to allow your body to be converted into a walking advertisement! The ambitious card engraver who hired you deserves some credit for the pattern of your coat; cunning man was he who thought of clothing you in a long sleeveless garment, and sewing the business and visiting cards of his customers on to it, so that you look like a mountain of white, green, and other diverscoloured cards. Your head may have but little brains inside; but, anyhow, the outside affords a fixed point 
whereon to fasten a huge card-board cocked hat, with a card weathercock upon it bearing the name of your employer the card engraver (whose name, notwithstanding all the trouble he has taken to impress it upon me, I forget). Poor ghost, we hope you are well paid for your labour !

A stout acrobat, dressed in dirty cotton garments, clears a circle, by means of flourishing a ball of some soft material at the end of a rope round and round his head, causing the spectators to give him space. The circle formed, "The Infant Hercules," a title assumed by a man six feet high, and with limbs like a giant, advances with would-be grace into the centre, and salutes with his great red hand the crowd, particularly the occupiers of the booth opposite the spot he has chosen as the arena of his performance. His pale, half-starved looking wife brings him a cup and a heavy metal ball; he ties the cup on to his forehead, and then, jerking the ball high up into the air, catches it in the cup. The ball enters with a thud; the man staggers a little: never mind; he would not perform the trick if it really hurt him. He then takes two cannon-balls, the size of small Dutch cheeses, out of his sack, and tosses them about as if they were made of elder pith; he makes them run up his arm to his ear, round behind his head, and down the other arm and back again; he causes them to jump up, by simply 
straightening his elbow-joint; he dances them on his feet while he lies on his back, and seems to delight in making them do everything that is contrary to the laws of gravity; there is no sham about it, for the cannonballs are handed round for examination, while the poor wife collects contributions in an old theatrical cap with a dingy feather in it.

After turning his body into sundry positions, which one would have thought possible only for a man made of India-rubber to do, a foolish and dreadful trick with a needle next followed. He placed a bare needle, point uppermost, in the turf of the race-course, and then drew it out again by causing the point of the needle just to enter the skin of his eyelid, his body all the time being in the abnormal position of the Zawnee for which $Z$ stands in the child's pictorial alphabet. Being invited to see that there was no deception, I satisfied myself on that point, and afterwards asked the man how he could possibly practise so dangerous an experiment.

He told me he had performed this needle-trick nearly twelve years, and that he learned it from a Dutchman. I warned him of the danger should he slip. "He knew that," he said; but "he had a wife and a family to support." Poor fellow, to be thus obliged to risk his life, I may say several times a day, on the chance of getting a few coppers! 
Amid the din of the grinding organs, I hear a musical sound unknown to my ears, and find that it proceeds from an instrument consisting of piano wires tightly stretched on a triangular board; the player has a thin stick in each hand, with which he strikes the wires, producing melodious and musical notes, which might be pretty in a drawing-room, but which are quite drowned amid the thousand sounds of more obtrusive instruments and the hum of human voices. The poor man looked disheartened;-his instrument does not take; and I fear me the performer on the musical glasses does not fare any better; the tips of his fingers, I see, are hard and horny, from perpetually playing, and he looks thin and ill fed.

I then witnessed a very curious exhibition, viz. the "stone-cracker." A man comes in front of the drag, and fixes a small square board, supported on a pole, into the ground. He then produces from a sack a stone. $\mathrm{He}$ places the stone on the board, flourishes his arm about in the air, and then bringing his closed fist suddenly down upon the stone, cracks it as though his hand was an iron hammer. I got the stone-cracker to turn the stones out of the sack for me to examine. They were ordinary stones, picked up from the roadside, generally about the size of a man's double-fist, and consisted of lumps of flint, limestone, and even granite. I picked out a bit of grey Guernsey granite (evidently a portion of our 
London street-paving stone), and placed it on the board to be cracked. The stone-cracker gave it a sharp blow with his fist, and it fell into halves in a moment. I examined the man's hand. The portion of his hand which acted as the head of the hammer was the pad of flesh by the little finger which forms the outside of the hand. The skin, \&c., here was formed, from frequent stone-breakings, into a solid horn-like mass, but his arm and forearm did not seem to be particularly well developed, not so well as we see in regimental farriers and blacksmiths.

I conclude, therefore, that the stones are cracked more by a peculiar knack of hitting them than by actual force. I have the bit of granite I saw broken by the stone-cracker in my museum; it is nearly two inches thick. This curious performer boasted that he could crack a milestone with his fist; and I believe it possible if the stone was of oolite, and not over-thick in substance.

Since the first edition of this book was published, I have received the following :-

" 155 Southgate-road, N. 13th February, 1866.

"Dear Sir,_-In the third series of your interesting work, 'Curiosities of Natural History,' you introduce the 'stone-cracker' to your readers, and make the 
following remark:-'I conclude, therefore, that the stones are cracked more by a peculiar knack of hitting them than by actual force.' If at all interesting to you, I beg to offer the following as an explanation of how the trick is done. About half a dozen years ago I was at Dover Regatta, and there saw a lame man break stones in the following manner. He first placed a small wooden stool upon the ground, and then produced a piece of rag, which (having first unfolded to show that nothing was concealed within it) he wound round his right hand, crossing it over the palm and back, and excluding the thumb. He said that he wore this to prevent splinters from cutting his flesh. Having done this, he pulled from a bag a flint stone and a piece of granite, each about the size of a man's hand, and from two to three inches thick; he then placed the granite firmly upon the stool, and the flint he held with his left hand, apparently resting it upon the top of the granite. Then giving his right arm one or two swings in the air, and uttering a shout, he (with the covered portion of his hand) hit the flint, and split it in two. Being considerably astonished at this apparently extraordinary feat, I waited, and saw it repeated; and then I noticed that during the time he was swinging his arm, he quietly raised the flint stone about half an inch from the granite, so that, when he gave the blow, the former 
received a sharp concussion from coming in contact with the granite, and this, I presume, caused the fracture.

"By keeping the above plan in view, I was able to crack, with comparative ease, the same kinds of stone as the performer did, and found that very little practice was required.

"Yours obediently,

"B. F. Davies." 


\section{CATCH-PENNIES.}

THE edges of certain pavements in London have become regular markets for semi-gratuitous exhibitions.

There used formerly to be a man, who stood in Leicester-square, who sold microscopes at a penny each. They were made of a common pill-box; the bottom being taken out, and a piece of window-glass substituted. A small eye-hole was bored in the lid, and thereon was placed the lens, the whole apparatus being painted black. Upon looking through one of these microscopes, I saw hundreds of creatures, which I at once recognized as paste eels, swimming about in all directions; yet on the object-glass nothing could be seen but a small speck of flour and water, conveyed there on the end of a lucifermatch from a common inkstand, which was nearly full of this vivified paste. Another microscope exhibited a single representative of the animal kingdom, a parasite of our own race, showing his impatience of imprisonment by kicking vigorously. I could not help admiring the beauties of construction in this little monster, which, if at liberty, would have excited murderous feelings, unSER. III.-YOL. II. 
favourable to the prolongation of his existence. The sharp-pointed mouth, with which he works his diggings -his side-claws, wherewith to hold on while at work - the little heart, pulsating slowly but forcibly, sending a stream of blood down the large vessel in the centre of his white and transparent body, could be seen and wondered at. When the stock of this sort of live game runs short, a common carrot-seed is substituted; which, when looked at through a magnifier, is marvellously like an animal having a thick body and numerous legs projecting from the sides; so like an animal, that it has been mistaken by an enthusiastic philosopher for one created in, or by, a chemical mixture in conjunction with electricity; at least, my father always declared that the insects created by the late Mr. Crosse were simply carrot-seeds.

I bought several of these microscopes, and determined to find out how all this could be done for a penny. I took them to my friend, the late Professor Quekett, and we examined them together. We found that their magnifying power was of about twenty diameters. The cost of a lens made of glass, of such a power, would be from three to four shillings. How, then, could the whole apparatus be made for a single penny? A penknife revealed the mystery. The pill-box was cut in two, and then it appeared that the lens was made of Canada balsam. The balsam had been heated, and, 
when it had assumed the proper size, shape, transparency, and polish, of a well-ground glass lens, it has been carefully dropped on to the eye-hole of the pill-box. Our ingenious lens-maker informed me that he had been selling these microscopes for fifteen years, and that he and his family conjointly made them. One child cut out the pill-boxes, another the eye-hole, another put them together, his wife painted them black, and he made the lenses.

Not long afterwards, in another part of the town, I came across another microscopist. He did not sell anything, but merely charged a halfpenny for a peep. His apparatus consisted of a tin box, the size of a common tea-caddy, placed on three legs, at about the level of a small boy's eye : these ingenuous youths being his principal customers. The fee being paid, the slide was drawn away from the peep-hole, and the observer addressed in the following words:- "Here you see a drop of Thames water, which looks like a gallon; the water is full of heels, snakes, and hadders a-playing about and a-devouring of one another." It was filled with numerous little creatures, which, having very small bodies, have as a sort of compensation received very large Latin names from their discoverer. Many of them were swimming about, pursued by what appeared to be immense sea-snakes. Others were quietly reposing on weeds, which looked like elm-trees, and all of 
them were perfectly unconscious of being exhibited to the British public at a halfpenny a head. But this was not all : the exhibitor next brought out of his waistcoat pocket a small tin tube, and said, all in one breath, "There you see a flea chained round his neck with a silver chain he lays his heggs on the glass and I feeds him three times a day on my 'and-the performance is now concluded."

Another man, in the optical line, has two tubes, like telescopes, placed facing each other. $\mathrm{He}$ asks you whether you can see through an inch board? Of course you say "No." "Then for a halfpenny I'll show you that you can," says he. Accordingly you look through the end of one of the tubes, seeing, of course, through the whole length of the other; for the benefit of the bystanders you are then requested to read some printing placed at the end of the furthest tube. This is easy enough. He then places a thick board between the two tubes, and still you can read the printing, which you are again requested to do; having purchased the power (on that occasion only) of seeing through a deal board for the small charge of one halfpenny.

In Tothill-street, Westminster, or the Tottenham Court Road, on a Saturday night, when what I call the "Poor man's market" is going on, a glass-blower may sometimes be seen, who goes his rounds to sell the products of his industry. A glass pen, a glass Neptune's 
tricient, a glass dove fastened to the top of a pointed wire, so as to form a breast-pin, and a glass peacock with a beautiful tail of spun glass are wrapped in a neatly-made brown paper bag, and sold for the sum of one penny.

Workers in iron also endeavour to catch an honest penny. There is a man who sells for twopence a most ingenious contrivance for roasting meat. It consists of no less than five pieces of iron wire, which, when put together, are strong enough to hold up a good-sized leg of mutton. One of the pieces serves as a fastening to the mantelpiece, and the others are attached to it by one of the pieces aforesaid. The cook is enabled by a simple mechanism, not unworthy of a Brunel or Stephenson, to heighten or lower the meat according to the state of the fire. If the inventor of this apparatus had a chance, there is no telling how many benefits he might confer upon mankind, and, let us hope, upon himself too, by his mechanical talents.

In Leicester-square, where penny-catchers most do congregate, razor-paste, at one penny a box, is sold by a dexterous shaver, who chops such large gashes in a hard bit of wood with a shilling razor, that he makes the wood fly about. He then passes the blunted instrument a few times over his magic strop; and, pulling a hair from his head, divides it as it stands erect between his finger and thumb, with the same 
ease that Saladin divided the scarf with his scymetar, and the Life-Guardsmen, at an assault of arms, cuts a sheep in half with the broad-sword.

The paste is, very likely (and so is the razor), more efficacious in the hands of the proprietor than of the purchaser; nevertheless, it is a good pennyworth.

I am forming a collection of various articles bought for one penny in the London streets; and I would beg my reader not to pass by these ingenious, poor, hardworking people, but to give them a kind word of encouragement, and a little assistance by purchasing a sample of their goods. 


\section{BARNUM'S BABY SHOW.}

Fond as the English people are of comparing notes as to mutuai progress, whether in Nature or Art, by means of public exhibitions, they have not yet arrived at the idea of exhbjiting samples of themselves. Our American cousins, on the contrary, exhibit living specimens of the rising generation.

Barnum, the king of showmen, having exhibited almost every thing in creation, has actually and positively duly advertised and invited the inhabitants of Boston to visit his Baby Saow.

Of this I hav certain and good evidence; for Mrs. Blackwell, the wife of my cousin, the late Thos. Blackwell, Esquire, Ençineer to the Grand Trunk Railway, Canada, lately retuned from her travels in America, has kindly put into my hands the bill of this Baby Show. 


\section{B A R UM'S MU SEUM,}

Every Day and Evening this Week, commencing Monday, June 2nd, 1862.

GRAND NATIONAL.

\section{$\mathrm{B}$ A B Y $\mathrm{S}$ H O W ! ! !}

100 BEAUTIFUL BABIES

Will be on exhibition for prizes, for which upwards of 2, 000 DOLLARS CASH WILL BE DISTRIBUTED FOR THE

FINEST BABIES, TWINS, TRIPLERS, RUATERNS, AND

FAT BABIES!

Amongst the Babies is one from Cincinnati, Phio,

8 MONTHS OLD, WEIGHING BUT 1 POUND 7 OUNCES, The smallest speck of living humanity ever seen. An ordinary finger ring slips easily over its hand and arm to th/ elbow. No conception can be formed of the exceeding diminuifreness of this little atom of the human race, which is really the

\section{GREATEST WONDER OF THE WOR D !
There are also}

THIRTY-TWO PAIRS OF TWINS, FOVR TRIPLETS, And numerous FAT BABIES, beside the greai number of single Babies, making it the

GREATEST GALAXY OF HUMAN WONDER EVER BEHELD!!!

The Premiums will be distributed among t1e most meritorious by Lady Judges of the highest re,pectability.

The Premiums range from 500 dols.! 250 ols.! 150 dols.! 100 dols.! 50 dols.! down to 5 dols.! and it all over seventy cash premiums will be awarded!

The Babies will be on exhibition every day from 11 a.m. till 3 p.m., and from 7 till 8 p.m., in the following order:- 
Monday, June 2nd.-From 11 a.m. till 3 p.m., Babies of all ages will be exhibited. First premium declared at 3 p.m.

Monday, June 2nd.-From 7 till 8 p.m. This and each other evening, Babies, Twins, Triplets, Quaterns, and Fat Babies over 4 years of age.

Tuesday, June 3rd.-From 11 a.m. till 3 p.m., Babies under 1 year of age exhibited.

WeDNESDAY, JuNE 4th.-From 11. a.m. till 3 p.m., Babies from 1 to 3 years of age, and Babies from 3 to 5 years exhibited in two different classes. Premiums declared at 3 p.m.

Thursday, June 5th.-From 11 a.m. till 3 p.m., all the Premium Children exhibited.

Fridar, June 6th.-From 11 a.m. till 3 p.m., all the Premium Children exhibited.

Saturday, June 7th.-From 11 a.m. till 3 p.m., all Premium Children exhibited.

All the Twins, Triplets, Quaterns, and Fat Children, as well as the Baby taking the highest premium, to be seen on the $2 \mathrm{nd}$, $3 \mathrm{rd}, 4$ th, 5 th, 6 th, and 7 th of June, from 11 a.m. till 3 p.m.

** Ladies and Children desirous of avoiding the discomforts of a great crowd will do well to come early in the morning, and see the Museum and other Curiosities before the Baby Show commences. Not later than 9 or 10 o'clock.

Walker and Sneden's Self-rocking Cradles, highly recommended by Physicians, and also Dr. Brown's celebrated Patent Baby Tender, have been provided for the use and comfort of the Babies.

My informant tells me that, according to the wish expressed in the bill, she attended early, but even then found the room crowded with visitors. The babies 
were arranged in two rows along the side of the room. The very tiny ones were held in their nurses' arms, who sat on chairs on the level of the floor; separated, however, from too anxious admirers by a strong hand-rail.

Above, and at the back of the row of nurses, was erected a platform, and upon the platform were exhibited the elder babies, each one in a separate chair, into which it was judiciously and carefully fastened, so that falling out was impossible.

Strange to say, these babies were very good and quiet; they did not tumble or twist about, or cry, or behave themselves in any way that did not become a baby exhibited in public. The fat babies were especially quiet, for they went fast asleep in spite of the crowds of people looking at them.

The "Cincinnati speck of humanity" was not well enough to be always on view; so, at stated periods, a bell rang, and it was brought out for examination. This poor little creature excited great curiosity among the visitors.

I wondered much that the poor babies did not cry; but I understand that American babies are not like European babies-they express no sentiments whatever till after they are three years old-they then develop themselves at a rapid rate. 
Besides the "Baby Show," visitors were invited to examine the Living Whales, the Sea Lion, the Bear "Samson," the Albino Family, the Grand Aquaria, the Happy Family, \&c. Admittance to everything 25 cents. 


\section{"OLMAR WALKS WITH HIS HEAD DOWNWARDS."}

Is November 1862, the London streets were placarded with the single word "Olmar." This mysterious announcement time proved to signify that a performer bearing that name was about to become a candidate for public patronage. No clue being given in the advertisement to the nature of his performances, I, of course, was anxious to see in what they consisted; and I now venture to give some idea of the really terrific performances of Olmar.

The visitor, on entering the Alhambra in Leicestersquare, noticed suspended far above his head a ladder, a trapèze-swing, and a square-shaped wooden frame, from the sides of which depended large rings. It almost made one giddy to look up from below at this gymnastic arrangement, which was about 90 feet above one's head; and one shuddered to think that a human being could possibly display feats of activity at such a height in the air.

However, at the appointed time, Olmar appeared; 
and, after a series of feats on the trapèze and on the ladder suspended in mid-air at this frightful heightfeats which made one's blood run cold to look at-he began to walk with his head downwards. He ascended, this time, to the square frame as before stated, at a height of about 90 feet from the floor of the building. On to the lower side of the frame were affixed rings (about large enough to admit a Dutch cheese), and of which there were nine on each side of the square. He surveyed them for a moment, and then, quickly reversing himself on the rope, placed a foot in one of the rings, hanging head downwards. He then let go his supporting rope, placed the free foot in the next ring, and so walked away with his feet in the rings,-_his head being downwards,-right round the sides of the square. He went along at a very good pace, and I observed he managed to twist his head up every now and then, to see that he did not miss the ring with his foot. This performance was really fearful to behold. After ascending again to the ladder, he took a terrific jump from one side of it, and, passing through the air the whole length of the ladder, caught hold of the other end on the outside; in fact, he jumped the length of the ladder by passing along its side in the air-exactly the leap of one of the spider-monkeys at the Zoological_only that Olmar being a man had not prehensile feet nor a prehensile tail to assist him. He then twined one leg in the 
rope, which was now again brought within his reach, and descended slowly and gracefully, with a twisting motion, to the earth again; and right glad I should imagine he was to get there once more safely.

These performances are most fraught with danger, imminent, literally, at every step. To go through them must require pluck more than human beings generally possess-nerves and limbs of iron, quickness of motion and thought, combined with steadiness and agility. Accordingly, we see all these characteristics well marked in the personal features of Olmar. All that we can wish him is success, personal safety, and a steady nerve in his perilous career.

The performance concluded, I had a lengthened interview with Olmar, who kindly allowed me to make an examination of his physique. He is not a tall man, but is all muscle and strength : the power of his biceps and forearm is tremendous; his wrist has amazing strength in it; his pectoral muscles project like the breast of a bird; the muscles of his back are like those in the figures of Hercules in the statues by Roubilliac in Westminster Abbey; his chest has a large capacity; and he weighs, with all this power, but $130 \mathrm{lbs}$. It was very curious, also, to observe how that certain muscles in the abdomen and back, not developed in ordinary persons, are very much developed in Olmar. They are the very muscles which are called into play when he walks on 
the rings head downwards, and plainly show us how that nature has provided muscles for the working of the human frame in whatever position it may be placedeven when the head is downwards.

Olmar told me that his ladder was made of the best Jamaica lance-wood; the bar of the trapèze was $4 \frac{1}{2}$ feet long, and 2 inches in diameter; the apparatus with the rings (which are iron covered with rope) was 90 feet from the floor of the Alhambra.

He was eleven years learning to walk in the rings head downwards, and it was nine years before he had confidence enough in himself to perform in public. The great difficulty he experienced at first was to "keep the blood out of his head" when in this position, and it was ten months before he trained his head to it.

It was no trick, but simply a feat requiring great courage and coolness. When near the ground, he could walk along from 150 to 170 rings without difficulty. He showed me the amazing power of his foot; for when he bent the toes upwards, it was with difficulty that I could force the foot down again. The tendons working the foot are as strong as iron wires.

He learned his aërial walking lesson gradually, as a little child learns to walk on the floor of the nursery; eren then, he was obliged to practise by himself every morning. He considered his most difficult feat was balancing himself by one foot on the trapèze-bar, even 
when the bar was close to the ground. He knew no other professional who could do it; the bar is so apt to slip away from under the foot, for it is very unsteady, and trembled greatly with his weight.

Olmar, I was pleased to see, was not inclined to "swagger" or be conceited about his performance: he acknowledged its danger; but long practice, perseverance, coolness, pluck, and strength, enabled him to overcome this danger. He had never yet met with an accident; and trusted that his personal qualities, with great care in fixing the apparatus, would enable him to escape harm or injury for the future. 


\section{THE INDIAN ROPE FEAT.}

IN "The Field" of October 29, 1864, I gave a detailed account of "The Davenport Brothers," and expressed my firm conviction that the whole thing was a clever trick, and had nothing whatever to do with what is called Spiritualism-whatever that may be-but was simply a modification of what is called "The Indian Rope Feat," which I had described in "The Field" some years previously.

The performer of this Indian rope feat again appeared in public at the time that all the world was talking about the Davenport Brothers; his object being to show that there was no spiritualism about the matter. Herr Tolmaque was the name assumed by the opponent of the Davenport Brothers.

I was asked to tie Herr Tolmaque into a chair with rope in any number of knots.

Accordingly I presented myself at the time and place appointed, and, half suspecting some sleight-of-hand trick, I myself provided several yards of very strong rope.

SER. III.-VOL. II, 
The performer, an intelligent and good-looking young man, sat himself in a common wooden kitchen chair, and presented me with his rope. I asked if he had any objection to my using my rope?

"None whatever," was the reply; "and you may tie me in any way, and with as tight knots as you please."

Having examined the chair to see that that was all right and above-board, I proceeded first to pinion his arms, fastening them, "Jack Ketch fashion," behind his body; I then lashed them (tied as they were) tightly, with many knots and twistings, to the back of the chair. I then tied his two wrists tightly to the legs of the chair, pulling the ropes, I fear, cruelly tight-as he afterwards showed me where I had cut the skin; but he did not complain of this a bit, as he had offered me the challenge. I next, by means of "double half-hitches," fastened each ankle to the corresponding leg of the chair, then tied both legs together, finishing off the rope with an attachment to the back rail of the chair. I finally tied up his body, twisting the rope round and round, and fastening it wherever I could get a chance. The performer was now bound hand and foot, and could hardly move in any direction.

A large linen extinguisher was then placed over him, tied as he was, and I and the other spectators stood round, at a little distance, to see that no collusion took place. In four minutes and a half the performer gave 
the signal, the extinguisher was removed, and there sat Herr Tolmaque, perfectly free and unbound, and the ropes at his feet.

I had tied him with seven pieces of rope (the usual number is four), and the seven pieces of rope lay at his feet, in no way injured or cut except at the places where I had cut them off the main piece; and I had taken the precaution to mark my own cuts, so as to know them again.

I had not the slightest idea at the time how the performer managed to loose himself; but I fancy that he must use actual physical strength in so doing, as he seemed exhausted, and in a profuse perspiration.

Soon after the above appeared in "The Field," the following notice was published also in that journal. The writer I know to be a good observer, as well as a good writer. He tells us :-

"When I was at Dinan (Brittany) in 1833, a man came round the town under the permission of the mayor, headed by a drum. He was the most miserable object I ever saw, and called himself by the . npropriate name of the 'Living Skeleton,' \&c. A record of this is most likely at the Mairie to this day.

"We went to see him perform, and, amongst others, was an English as well as a French doctor.

"He first requested us to attach the two joints of the thumbs together above the bone: this we did with very 
fine whipcord, so excessively tightly bound round that one would have thought that the little blood (if any) that might be in him would have burst out at the end. But no; he quietly wetted the fastening, and as quietly withdrew one of the thumbs therefrom, leaving one centre of the figure $\infty$ versed.

" He did a variety of other experiments with padlocks, \&c., and finished by requesting us to procure a . moderately-sized chain (it was a long one, somewhat stronger than a jack-chain). With this chain the body and arms were encircled as tightly as two men could possibly haul it by placing their feet against his body. He made the remark to a gendarme present- ' I suppose that if you had got me now in prison, you would think you were all right?' - and then, by a sudden movement of the body, the whole of the chain fell to the ground."

-H. G. (Paris.) 


\section{"NATATOR," OR THE HUMAN FROG.}

ON Saturday, August 10, 1867, I was invited by Mr. E. M. Adams, the polite and active secretary of Cremorne Gardens, to give some account, in "Land and Water," of a most curious subaqueous performance. A huge human aquarium (for I can call it nothing else) is placed on the stage. It is made of iron, with a plate-glass front, and measures nine feet by five. It contains four tons of water, the depth being about six feet. It cost nearly $100 l$. When I arrived, the "human frog" had just begun his performances, and through the plate-glass I beheld a human form twisting itself round and round with the velocity of a cockchafer on a pin, and looking like a huge jack fighting in his last efforts to get rid of the fatal gorge-bait.

The following is a list of "Natator's" subaqueous performances. Firstly, he stands on his head; his head touches the bottom of the aquarium, his feet are at the top, like a couple of huge fishing floats. This is called the "minute trick," and is performed first in 
order to show the longest time that "Natator" can stay under water.

His second performance is to swim up and down the tank several times-twenty are the most-without coming once to the surface to breathe. He twists himself right round, and gives a slight push with the foot at each end of the tank, so as to reverse his motion. This is a very difficult trick, inasmuch as the aquarium is not long enough for him to take a full stroke, and he has to stop his force at either end as well as he can. The performance of this feat requires from 40 to 45 seconds under water.

Thirdly. "Natator" sits down (tailor fashion) at the bottom of the aquarium, and grins at the people through the plate-glass front. $\mathrm{He}$ opens and shuts his eyes under water, to show that this can be done. He also opens his mouth quite wide under the water; this, he tells me, is very difficult. Great practice has enabled him to do it, without swallowing a drop of water. He throws out air-bubbles once, and once only; this is necessary to enable him to sink to the bottom. While there, he neither emits air-bubbles nor, being under water (of course), takes in a fresh supply of air.

Fourthly. He again descends, and eats, under water, a sponge-cake or a bun. He opens his mouth, to show that he has really swallowed it. It is most difficult to 
swallow cake under water without also swallowing water. It required three years' practice to do this performance with safety; for if, when under water, he should happen to cough, the water would enter, he would instantly be choked, and a serious accident would ensue.

Fifthly. Ascending to the surface, a soda-water bottle is handed to him; he dives with it to his perch at the bottom, and drinks down the contents, viz. a halfpenny worth of milk; he chooses milk because of the colour, and in order that the audience may see that he actually drinks it from the bottle; this is a most difficult trick, as it is hard to swallow the milk without the water getting into the mouth.

Sixthly. A lighted pipe is handed to him; he takes a few whiffs above water, and then descends with it; when under water, he manages somehow to keep it alight, and to emit bubbles, which rising through the water, burst in little puffs of tobacco smoke. Coming to the surface, he shows that his pipe is still alight.

Seventhly. He does "poses plastiques" under water, placing himself in various attitudes, and then the piano strikes up the tune of "Froggy would a wooing go." The "human frog" dances to the music, frog fashion, at the bottom of the water, all the while singing the song. It is very curious to see the bubbles of air from his mouth, rushing up to the surface in greater or less 
profusion according to the number of words in the verse of a song which the spectator should follow in his mind. This would be an interesting study for Professors Wheatstone or Tyndall, to see how many bubbles of air were necessary to form an individual word. "Natator" tells me he can hear the piano quite plainly, when under water; this was indeed evident from the way his bubbles kept time with the music; and he also tells me, that if anyone speaks very loud outside the glass, he can hear him plainly. This bears on the question of fish hearing under water; but it must be recollected that a fish's ear is very differently constructed to a human one. We humans have no otoliths-a peculiar bony structure found in the fish's ear only. This otolith structure is necessary for hearing under water, for we find that the whale, in other respects an air-breathing, warm-blooded animal, with a four-cavitied heart, has his ear fashioned after the pattern of that of a fish.

Eighthly. "Natator" swims with a jerking motion like a shrimp, with a steady but sudden rush like a jack, with a lazy, sleepy floating like a hundred year-old carp in the royal ponds in Virginia Water; and lastly, being apparently seized with a fit of the "merrygo-rounds," performs a series of head-over-heels gyrations round and round, like a man practising upon a pole between bars in a school of gymnastics. He 
remains in mid-water, without touching the top or bottom of the tank, the whole time, and does not once come to the surface; this might well be called the "porpoise trick." The greatest number of head-over-heels turns that he performs (and this generally every night) is twenty-four, and he requires about fifty seconds to get through them.

The performance concluded, "Natator" allowed me to examine him in my medical capacity. He is a young man, twenty years old, 5 feet $7 \frac{1}{2}$ inches in stature, and 9 stone 6 lbs. in weight; he is lightly built, but exceedingly well made and muscular. His pulse on coming out of the water gave 148 beats to the minute; twenty minutes afterward they were 92 to the minute. I listened to the lungs and heart, and observed phenomena showing how wonderfully nature can accommodate the machinery of the heart and lungs in an airbreathing animal (I hope "Natator" will forgive the expression) to long stays in an element only suited for the existence of fish, and other cold-blooded vertebrata, and this without interfering with the good health of the individual.

With all his hard and very peculiar work, "Natator" (whose name, he has no objection to my stating, is Cooper, well known to professional swimmers) has excellent health. When he first began to practise long stays under water, some four years since, he used to 
suffer from severe headaches, but now these have quite disappeared; he never has rheumatism, or other ache or pain in any form, though he goes through his performance at half-past ten every night, and sometimes twice a day. The water in his aquarium he generally manages to keep at a temperature of about 62 degrees, but the warmer the water is, the longer he can stay in, and the easier his performances become. The longest time he has ever remained under water at a stretch has been 69 seconds, and several times he has remained 64 ; his ordinary tricks require from 10 to 30 seconds under water. He nearly had a bad accident with the first aquarium that was made for him; the front was composed of one large piece of plate glass. Just as he was about, at a rehearsal, to get into the water, the glass gave way with a sudden crash, and washed him with terrible force into the orchestra, which was instantly flooded. If he had been inside the aquarium, and not providentially outside, he must have been killed by the rush of water through the fractured glass. This glass is now subdivided into four, with strong iron frames, and the aquarium is perfectly safe. 


\section{THE PERFORMING BULL DON JUAN.}

The reader who, map and book in hand, has travelled with Livingstone, Galton, or Gordon Cumming across the desert wilds of South Africa, cannot fail to remember many stories of the sagacity, intelligence, and wonderful obstinacy of the genus Bos-how that at one time they cowered round the midnight fire, seeking protection in man's presence from the roaring lion-how that at another they snuffed the scent of water from afar, inspiring hope in the breast of the thirst-worn traveller -or how, at a critical juncture, no application of the long leather "rheim" or rhinoceros-hide whip would make them stir one inch.

Man has ever used the ox as a slave-seldom as a friend or a pet. When the human race was yet young, the ox was made the type of civilisation, and on this plea was by the astronomers of old promoted to a place among the signs of the zodiac, which honoured berth he has held to this day, "Taurus the Bull" being emblematical of settlement and culture-followed by Gemini the Twins, expressive of the fertility following agriculture, and the union of man in consequence. 
I have been unable to find any record of one of the ox tribe having, before the year 1859 , been trained to perform tricks-an art to which dogs, monkeys, horses, and " the talking fish" have hitherto alone attained. It was therefore with curiosity that I went to witness the performance of "Don Juan," the performing bull," at the Alhambra Palace, Leicester Square.* Before the performance, I examined the bull, who was quietly chewing the cud in his stall. He was a little fellow of the Spanish breed, about 4 feet 4 inches high; his coat was jet black, and shone like the coat of a racehorse from constant care and grooming. His master, Dan Costello, informed me that he would be four years old the next spring, and that he did not begin to train him till he was more than two years old. He saw him first in the island of Cuba, and took a fancy to him as a likely beast to turn out a docile pupil. $\mathrm{He}$ had previously tried several other bulls, with little success, before he found " Don Juan."

When the bell rang, the bull came into the arena with that long, heavy, swing-trot so peculiar to all the ox tribe. He was gaudily dressed with ribbons and silver knobs on his horns, a gaudy, red leather headstall on his head, a row of bells (such as are used for the French diligence horses) round his neck and body, which made a fine musical jingling as he moved 
about. After trotting round the circus, he came to the centre, and, kneeling down on both knees, put his head on the ground-a difficult posture for him to assume. This position was supposed to indicate a "camel." He then jumped through hoops, and over thick, wattled hurdles, which, however, he managed generally to kick with his hind legs as he went over (he was a bit lazy, this Mr. Bull). He jumped over poles (painted like the pole of a barber's shop), placed both separately and together. He went down on his knees, and walked half round the circus upon them, and at a famous pace he went shuffling along on his knees in the sawdust; but I was not surprised at this, as cattle in feeding on steep precipices often kneel down for safety and convenience in grazing. A box having been placed in the arena, the bull, at a sign (not a word of command) from his master, stopped in his trot, and, advancing to the box, put both feet upon it; he then walked round the box, keeping his fore-feet still upon it; and it was curious to see him change them over and over as he made the circle. A short staff having been fixed into the box, he put his foot upon the top of it, and kept it there for a minute or so, as if about to make an address to the public. After this he performed sundry minor pedestrian feats, much after the manner of a recruit at foot-drill; and when he-had done all, a large board was brought in, the 
bull's foot-stool was placed upon it, and the bull, walking upon the board, allowed himself to be lifted bodily up, on the board, and to be carried by ten men round the circus, one foot on the stool all the time. The knowing brute balanced himself as he felt the board shift from side to side. He pricked up his great ears, stared about with his lustrous eyes at the people and the gaslights, and no doubt thought himself a very fine fellow indeed.

Mr. Costello told me his animal was of a playful disposition, and thought it great fun to do his tricks even when there was no audience. It was feared that during his voyage from America (where he had been performing) he would have forgotten his lessons; but he had not, and seemed pleased to go to work again. His affection for his master was great, and he would not go through his tricks for a stranger. During his performance he now and then shook his great head, and whisked his tail about, as if to show that, like other animals, both biped and quadruped, he had a will of his own. The reader will agree with me that it is much more agreeable to see a bull made a useful pet than to see him tortured and worried to death, as is done in the Spanish bullfights, or rather bull-slaughters. 


\section{JAMRACH'S ANIMAL STORE.}

IN March, 1861, I received a note from Mr. Jamrach, the celebrated dealer in living animals, that he wished me to come at once and see a curious sight at his establishment, 164 Ratcliff Highway, facing the entrance to the London Docks. Accordingly I went.

"Well, Jamrach, what now?"

"You shall see, sir."

He took me upstairs, and opened the door of a room, and there I saw such a sight as really made me start. The moment the door-handle was touched, I heard a noise which I can compare to nothing but the beating of a very heavy storm of rain upon the glass of a greenhouse: I cautiously entered the room, and then saw that it was one mass, windows and walls, of living Australian grass parakeets. When they saw us the birds began to chatter, and such a din I never heard before.

On our advancing a step into the room, all the birds flew up in a dense cloud, flying about just like a crowd of gnats on a hot summer's evening, their wings causing a considerable rush of air, like the wind from a 
winnowing machine. Such a number of birds I never siw before together in all my life.

"Why, Jamrach, how many, for goodness' sake, are there?"

"Well, sir, you see, two ships, the 'Orient' and the ' Golden Star,' came in from Port Adelaide, Australia ; both ships had birds on board; I bought the lot, and have now three thousand pair of them. There are plenty of people about who would buy twenty, thirty, or a hundred pair, but I took the whole lot of 3,000 pair at a venture, and I am pleased to say we are doing very well with them, and we have not, as yet, lost very many. The 'Golden Star' birds are the strongest, as there were not above twenty or thirty pair in a cage; the 'Orient's' birds die faster, as there were from 200 to 300 pair in a cage. You see, sir, I have put them in two unfurnished rooms; " saying which, he opened the door of another room, and there I saw another edition of the first room, viz. another living mass of these beautiful little birds. Jamrach had fitted up a series of common laths from the floor of the room to near the ceiling, the laths being one above the other; and when the birds got a little quiet, there they sat all of a row - eight to the foot I counted-just like a number of our noble selves on the benches at a public assembly, making a continuous clatter and noise.

These grass parakeets are exceedingly pretty birds. 
Jamrach gave me a couple of dead ones. Their markings are as follows:-A lustrous green breast and body, yellow on the top of the head, and a species of beard on each side of the beak, pencilled with the most lovely violet; back of head and wings yellow, barred with black; tail blue, and body above the tail emerald green. They are about the size of a good big lark, and are very commonly sold at the London birdshops.

Jamrach having shown me the six thousand parakeets, asked me to go into his yard-an invitation which, of course, I accepted. In one little bit of a stable-yard, including the stalls and the loft, I saw the following miscellaneous collection of birds and beasts, all alive and well cared for:-One female zebra, one female wapiti deer, two llamas, four pairs of black swans, one fine jaguar, four emus, one kangaroo, four opossums (one being perfectly white), four pairs of curassows, one male axis deer, five wedge-tailed eagles, one pelican, one seaeagle, one griffin vulture, two Magellanic geese, one Cereopsis goose, one pair of Japanese pheasants, four pair of masked pigs from Japan, one Virginian owl, one pair of porcupines, two maraboos; and, in the next yard, a fine pair of double-humped camels, a fine male yak from Chinese Tartary, and a pair of bisons from the park of the late Marquis of Breadalbane.

All these birds and beasts were for sale. Where SER. III.-VOL. II. 
Jamrach can find customers, I know not: he is, however, in correspondence with almost every zoological garden, as well as with the owners of smaller collections of living animals, throughout the whole civilized world, whether in Europe, India, or America.

Many folks think they have seen all the sights of London; but there are numerous curious and interesting places which are comparatively unknown, and which are well worth a visit. Lovers of natural history who wish to see the "head-quarters of the animal trade," where wild animals and curious birds, \&c., are received and distributed to all parts of the world, should certainly pay Mr. Jamrach a visit. He will get his customers anything, from an elephant or giraffe down to a love-bird or a tortoise. 


\section{PERFORMING FLEAS.}

IN the month of July 1856 , I discovered an individual who for twenty years had devoted his life to the intellectual training of fleas. He carried on his operations in a little room in Marylebone Street, London. I entered, and saw fleas here, fleas there, fleas everywhere; no less than sixty fleas imprisoned and sentenced to hard labour for life. All of them were luckily chained, or fastened in some way or other, so that escape and subsequent feasting upon visitors was impossible. A little black speck jumps up suddenly off the table whereon the performance takes place-I walk up to inspect, and find that it is a monster flea attired "à la convict;" he is free to move abont, but, wherever he goes, a long gilt chain, tightly fastened round his neck, accompanies him.

Occasionally he tries to jump; the chain instantly brings him down again, strong as he is. If a flea be fastened to the end of an unbroken wheat straw, he will be strong enough to lift it right off the table on which it is placed. This discovery was first made by the flea 
proprietor, and made him turn his attention towards utilising the race. One would think it were not difficult to procure troops of fleas, and to train them to perform; but it appears that neither task is easy. It is very difficult to procure a lot of able-bodied fleas, and it is by no means every sort of flea that will do. They must be human fleas: dog fleas, cat fleas, and bird fleas are of no use-they are not lively enough, nor strong enough, and soon break down in their training. Human fleas, therefore, must be obtained somehow, and our friend has created a market for them. The dealers who supply the raw material are principally elderly females; the trade price of fleas, moreover (like the trade price of everything else), varies, but the average price is threepence a dozen. In the winter-time it is sixpence; and, on one occasion, the trainer was obliged to give the large sum of sixpence for one single flea. He had arranged to give a performance; the time arrived; he unpacked the fleas; one, whose presence was necessary to make up a certain number, was gone. What was to be done? the vacancy must be filled. At last, an ostler, pitying the manager's distress, supplied the needful animal; but he required sixpence for it, and sixpence he got.

While I was looking at the performance there came in a fresh supply of fleas; a swarm of them, in a vial bottle, huddled all together at the bottom. The flea 
trainer gave them a shake, and immediately they all began hopping about, hitting their little horny heads against the sides of the bottle (which was held sideways) with such force that there was a distinct noise, as if one had gently tapped the bottle with the nail. These fleas were not very good friends, for they were perpetually getting entangled in masses, and fighting with their tiny but powerful legs, and rolling over and over as if in mortal combat. They were not, however, fighting for life and death; for I did not see one that looked injured or tired after the mêlée.

I then observed one fact, which gave me great pleasure; namely, that fleas are at enmity with bugs. There was one bug in the bottle surrounded by many fleas; the poor bug rushed continually from one end of the bottle to the other, running the gauntlet of the assembled fleas; every flea he came near attacked him; at last, the bug, overwhelmed by numbers, had the worst of it, and beat an ignoble retreat into a bit of flannel.*

* Blackbeetles and Bugs. (Answer to correspondent in "Land and Water.")-A friend of mine, lately returned from the East, informs me that when cockroaches become too numerous on board ship, a good plan is to batten down the hatches and then turn on a steam hose with a full jet. The steam penetrates into every nook and corner of the ship, and soon settles all the black. coated free passengers. Our friend might put the big kettle on the fire, and fit an indiarubber tubing on to the nozzle, and try this plan in her kitchen; placing the indiarubber tube in the lowest 
Fleas are not always brought to market in vial bottles. The best fleas are imported from Russia, and come over in pill-boxes packed in the finest cotton-wool. These fleas are big, powerful, and good workers. I wonder whether the Custom House authorities think it worth while to examine the contents of these pillboxes. When our friend in Marylebone makes his annual tour into the provinces, his wife sends him weekly a supply of fleas in the corner of an envelope, bolt-hole of the blackbeetles. She should then pour gas tar down into all the holes, and stop them up with plaster of Paris; "benzine colas," or benzol, as sold by the chemists, is fatal to Cimex lectularius, as well as to blackbeetles. Returning home some time since, I found to my horror that there had been, not a "spat of oysters," but a "spat of Norfolk Howards" in my absence. I got some benzine colas and a glass syringe, and squirted it into all the cracks I could find. The inmates turned up instantly this fluid touched them, and by means of the syringe I managed to bring them out from their inmost burrows. The operator must take care that the benzol does not touch the eyes, and that no fire is about when it is being used, as it is highly inflammable. The same evening that I destroyed the "terrors," the old English for these nocturnal pests, I went down into the kitchen, when the gas had been put out about half an hour; on the floor were numbers of blackbeetles, having a free-and-easy. I took with me an assistant, three glass squirts, and a widemouthed bottle of benzol. As the blackbeetles scuttled away to their holes, I kept firing at them, killing some dead and wounding others, for the next morning we found plenty of " dead birds" about the kitchen. With an active loader to manage the second syringe, and plenty of black game, blackbeetle shooting at night in the kitchen will give as much sport as rabbit shooting in a warren by day. 
packed in tissue-paper. She is careful not to put them in the corner where the stamp goes, as the post-office clerk would, with his stamp-marker, at one blow, smash the whole of the stock.

A flea cannot be taken up from its wild state and made to work at once; like a colt or a puppy, it must undergo a course of training and discipline. The training is brought about as follows :-The flea is taken up gently, and a noose of the finest "glass-silk" is passed round his neck, and there tied with a peculiar knot. The flea, unfortunately for himself, has a groove or depression between his neck and his body, which serves as a capital hold-fast for the bit of silk; it can slip neither up nor down, and he cannot push it off with his legs; he is a prisoner, and is thus tied to his work. This delicate operation is generally performed under a magnifying glass; but, after a time, the eye gets so accustomed to the work that the glass is not always used. In no way is the future performing flea mutilated; his kangaroo-like springing legs are not cut off, nor are his lobster-like walking legs interfered witha flea must be in perfect health to perform well.

The first lesson given to the novice is the same as that given to a child, namely, to walk. To effect this, he is fastened to the end of a slip of card-board, which works on a pin as on a pivot; the moment he feels himself free from the hands, or rather forceps, of the 
harnesser, he gives a tremendous spring forward : what is the consequence? he advances in a circle, and the weight of the card-board keeps him down at the same time. He tries it again with the same result; finally, he finds the progress he makes in no way equal to his exertions; he therefore, like a wise flea, gives it up, and walks round and round with his card-board as quietly as an old blind horse does in a mill. To arrive at this state of training requires about a fortnight; some fleas have more genius for learning than others, but a fortnight is the average time.

There is another mode of training fleas : it is to shu them up in a small glass box, which turns easily between two upright supporters. The flea, when first put in, hops wildly about, but he only hits his head against the top of the box, and at the same time is supposed to get giddy with the turning round of his prison.

Among the trained fleas already at work, I noticed the following groups. A coach with four fleas harnessed to it, who draw it along at a pretty good pace; I should feel inclined to back the coach in a race against a common garden snail. The coach is very heavy for the little creatures to drag along, for one pane of glass in the window is equal to the weight of one hundred fleas. There is a large flea, whose daily task is to drag along a little model of a man-of-war; it is amusing to see him 
push and struggle to get it along; but get it along he does, although it is two hundred and forty times his own weight. Again, there are two fleas secured, one at each end of a very little bit of gold-coloured paper. They are placed in a reversed position to each otherone looking one way, the other the contrary. Thus tied, they are placed in a sort of arena on the top of a musical box; at one end of the box sits an orchestra composed of fleas, each tied to its seat, and having a minute model of some musical instrument tied on to one of its legs. The box is made to play, the exhibitor stirs up each of the musicians with a bit of stick, and they all begin waving their legs about, as if performing and keeping time to an elaborate piece of music. The fleas tied to the gold-coloured paper feel the jarring of the box below them, and begin to run round and round as fast as their little legs will carry them. This is called the Fleas' Waltz.

Tightly secured in a chair sits a flea facing a tiny cannon. Several times a day this unfortunate insect fires the cannon, and in this wise :-One of the little slips which form the feather of a quill-pen is fastened on to one of his legs, and a little detonating powder placed on its tip; the exhibitor then presses the wand down on to the cannon, and scratches the detonating powder; it goes off with a sharp report, making the lookers-on jump, but it astonishes nobody more than 
the flea himself; he flourishes the burnt remains of his firing wand madly about in the air, his numerous legs kick about violently, his little head bobs up and down, and altogether he shows as many symptoms of alarm as it is possible for a flea to exhibit. The individual flea that I saw in this state of trepidation did not seem to have got used to his work, though the poor thing had been firing his cannon about thirty times a-day for a month.

The fleas are not kept always in harness; every night each flea is taken out of his trappings, is fed, and placed in a private compartment in a box for the night; before they go to bed, they have their supper, and in the morning also their breakfasts; they take their meals from the hands of their owner-sometimes he has nearly all his fleas on the backs of his hands at the same moment, biting and sucking away simultaneously. For more than twenty years has he thus daily fed his fleas without any detriment to his health; the quantity of blood each flea takes away being imperceptibly small -one drop of blood, he considers, would feed a flea for many weeks; but it is the itching sensation caused by the flea cutting the skin which is unpleasant. This feeling of irritation he felt painfully when he first began to submit himself to the tender mercies of his little performers : now he is so hardened that he feels them not at all, whether biting or sucking. When, 
however, there are many fleas feeding on his hands at the same time, he suffers from a sensation of great irritation all over his body, which passes away when the supper is over. He has remarked that his fleas will not feed if his hand be not kept perfectly motionless; the act, therefore, of feeding and harnessing his company of performers is troublesome, and he is obliged to devote two hours in the morning and two in the afternoon to it. His fleas generally live a long time, provided they are properly fed and taken care of. He once had a flea, a patriarch, who for eighteen months was occupied in pulling up a little bucket from a well; this flea lived longer than any other he ever had, and he believes he died finally from pure old age; for he was found dead one day, faithful to his post, with his bucket drawn half-way up the well.*

* See Appendix. 


\section{THE ELEPHANT HORSE.}

IN the month of November 1863, I received the following elegant epistle from a showman :-

"Ass I no you like to hear of any thing extra ordinaire in the Annimal Line $\mathbf{I}$ inform you that by Wendsday I shall have an African Horse quite Nacket* with the Exception of the Tale I believe the first One imported in England."

I could not accept the invitation at the time, but shortly afterwards I heard that an "Elephant Horse" was being exhibited at Mason's Riding School, Brompton. The handbill described it " as having been brought from Ceylon by an officer in the Indian army," \&c. \&c. When the proprietor brought out his living wonder, I perceived that the curiosity of this animal consisted in the fact of its body being nearly denuded of hair, it was, in fact, the "Nacket" horse exhibited under another name. There was hair upon the legs; but upon the neck, quarters, and part of the head, none whatever-these parts were as bald as the palm of the hand, and pre- 
sented a black, shining appearance, not unlike the skin of an elephant. The tail was also hairless, with the exception of a little tuft just at the end of it. In these respects only it resembled an elephant.

I am informed by Mr. Pinkerton, that in the "Philosophical Magazine" for 1801 is an account of another "Nacket" horse, which was exhibited in 1796 as "The Nile Horse."

Just one year before the "Elephant Horse" was exhibited, there was shown at the Burlington Mews, Regent Street, a wonderful Three-legged Horse. It was simply an ordinary-looking colt (about five months old), in which the hind legs were perfect, but the left fore-leg was deficient, as though it had been amputated by a surgeon. I ascertained that, though the entire leg was wanting, its scapula or bladebone could be felt under the skin, and the joint where the shoulder ought to be projected from the skin. When the animal moved forward, this bladebone was seen moving under the skin, as though the leg was actually present. There was no mark or scar of wound made by human hand; and I believe the leg had not been amputated, but that it had never been developed at all, and that the absence of the leg was a natural and congenital deformity. It was remarkable to observe how nature had compensated the animal with a view to the support of the head and neck -a weight which (by her own showing in the formation 
of ordinary horses) requires two props, not one; we therefore find the right leg powerfully developed, and the muscles about its bladebone and fore-arm strengthened to a most extraordinary degree; they had double work to do, and, like wise things, put on double steam to do it. Again, we must notice the position of this one leg. On looking between the hind legs, we observed that whatever position the animal assumed this one fore-leg appeared to be exactly underneath the centre of the chest; this, in fact, was its real position, and we hereby get a good lesson in animal mechanics. The "action" of the animal was something quite new; it may be aptly called "kangaroo" action, or, if you want a more familiar example, "hare" action-the progress made by the creature reminding one of a hare when moving slowly along by the side of a covert. T'he groom of the horse put his charge through his various paces: "Il marche, et trot, et galop," said he; but all his paces may be thus described in the words, " hop-stop," " hop-stop." The groom was a lively and good-tempered Frenchman, who, in order to be in due keeping with his charge (which was born in Zealand, Netherlands), wore the costume of a Dutch peasant-and a most extraordinary costume it was; his gold and silver buttons were really something wonderful in size and fashion. The groom was as well worth seeing as the Three-legged Horse. 
About the same time that I published the above account of this curious horse, I heard that there was a match to it, in the shape of a three-legged cow, which was turned out in a field at a place called West-End, beyond the Swiss Cottage, and near the Cock and Hoop public-house. The cow, like the horse, had one of its fore-legs wanting, and had kangaroo action also.

I regret I had not time to go and see this three-legged cow. 


\section{THE TALKING FISH.}

IN June 1859 , long before its arrival in London, notices of this creature appeared in every form likely to attract the public eye; and everybody wondered how a fishan animal which has no organs of voice-could "talk," and how its mal-developed brain could be taught to "learn performing lessons." It must be recollected that this was the first time the clap-trap phrase-Talking Fish-was coined. The first glance at the living wonder dispelled all my hopes of something new. No scaly, leaden-eyed, cold-blooded fish lay basking in the huge exhibition tub; but, instead of a fish, a beautiful seal, in the finest possible health, raised its intelligent head to my disappointed gaze.

This seal, a fine specimen of its kind, between ten and twelve feet long, is decidedly Phoca leponyx, or the small-nailed seal.

Jenny, for that was the name of the Talking Fish, had been taught to go through a series of rude performances at the word of command. Closing her hand-like 
fins to her side, she rolled herself round and round in the water like a leg of mutton cooking before the fire: this performance was called "roasting the pig." She then raised herself out of the water, and with her nose touched her master's right or left hand at command. After another series of revolutions in the tub, she raised herself on to its edge, and, stretching out her long wet body a considerable distance forward, placed her cold wet nose against her master's face, by way of showing " how to give a kiss."

So much for the performing; now for the talking. Understanding the orders given, she uttered what I believe to be her natural cry, and which, when the spectator is told it means "mamma," or "papa," is certainly very like those infantile words. The papers stated that she could "call John," but she did not get further than "mamma," or "papa," nor indeed is she likely to be made to improve upon her own natural language, which, luckily for the proprietor, may be said to resemble our own as regards the two simple words stated above ;-a good parrot, magpie, or starling, would beat the fish hollow at talking.

The "Talking Fish" was, I believe, a success; principally due to the name under which it was advertised. Numerous "talking fish" have since been exhibited, but proved failures, as the public are now well aware SER. III.-VOL. II. 
of what a "talking fish" really is. One of these seals distinctly pronounced the words "beer, beer;" an ingenious device on the part of the exhibitor to obtain by means of the vocal powers of his "fish" bodily refreshment for himself. 


\section{THE SEA BEAR.}

IN April, 1866, a very beautiful seal was exhibited at the Zoological Gardens. It was vulgarly called "the Sea Bear," the proper name being Otaria Jubata. A good engraving of this handsome beast will be found in "Land and Water," No. 13, April 21, 1866.

In 1862 some French sailors, wandering about the desolate and bleak shores near Cape Horn, came across this sea bear. After a great deal of manœuvring, one of the men, named Le Blanc, managed to get behind the seal, and catch hold of his hind flippers. The beast, of course, tried to turn to bite; but Le Blanc, by turning quickly to the right or to the left, kept out of the way of his teeth.

When the animal was a bit tired, the other sailors managed to get a stick into his mouth, and tie it tight behind his head, so as to gag bim. They then bound him up tightly with ropes, and slinging him between two oars, carried him to their ship, and then to Buenos Ayres. Le Blanc conceived the idea of taming his capure, and for two whole years devoted himself entirely 
to this object, in which he perfectly succeeded, not, however, without difficulty, for he bears marks of the seal's teeth on almost every limb, and his right hand is quite crippled by a bite, in inflicting which the seal almost severed the muscles of the forearm; in fact, the wound was so severe that the South American doctors wanted to amputate his hand altogether.

Notwithstanding the ferocity of his pet, Le Blanc cultivated his intelligence, and the creature now performs tricks which Le Blanc, with true nationality, has worked up into a little military episode. The seal volunteers to go as a soldier to Mexico. He then passes through the forms of enlistment and drill, and finally fires a cannon. He eats twenty-five pounds weight of fish daily. His habit is to sleep all night and during the day when his master is not with him. He wakes at the slightest noise. He does not object to visitors; but is annoyed if he sees ladies wearing white ribbons.

The great peculiarity of this seal is his flippers. As in the case of the ant-eater, when naturalists of olden times first stuffed the skin, they unbent the claws, and put them flat on the board like a rabbit's paw; so in the case of this seal-most people, until this living specimen arrived, thought that he and his kind walked or rather crawled with the chest on the ground like other seals. It is, however, now quite certain that the sea bear supports his body as it were upon short legs, and that his 
huge flippers serve him as gigantic feet, reminding one of Bob Ridley's shoes in nigger performances. The claws are especially to be remarked, as they are not at the end of the limb, but placed somewhat backwards, like a man's hand in a pair of gloves much too long for him.*

* I regret to say that in February, 1867, the poor sea bear died, in consequence of having swallowed a fish-hook in a fish given him to eat. Poor Le Compte was disconsolate at the death of his pet. 


\section{MERMAIDS.}

Mermaids seem to have gone out of fashion about the same time as the dried heads of New Zealanders, but still I have been enabled to examine minutely three specimens of mermaids here in England. They are all the same in structure, and remarkable only for the ingenious way in which they have been put together. The original mermaid exhibited at the Egyptian Hall was bought for 40,000 dollars by two Italian brothers, and there was a long lawsuit about it, as there was afterwards about the "Talking Fish."

There is a very capital mermaid now to be seen at the Oriental warehouse of Messrs. Farmer and Rogers, 179 Regent Street. By the kindness of Mr. Liberty, who took the mermaid out of her case, I was enabled to examine her minutely. She certainly is a curious-looking thing; though of course to any one with the slightest pretence to knowledge of natural history a decided make-up.

The total length of her marine ladyship is 25 inches, and she is composed in the usual regulation mermaid 
style, viz., half fish and half quasi-human, or, as Horace says-

Desinit in piscem mulier formosa superne.

The lower half of her body is made of the skin and scales of a fish of the carp family, neatly fastened on to a wooden body. The upper part of the mermaid is in the attitude of a sphinx, leaning upon its elbows and forearm. The arms are long and scraggy, and the fingers attenuated and skeleton-like. The nails are formed of little bits of ivory or bone. The head is about the size of a small orange, and the face has a laughing expression of good-nature and roguish simplicity. I cannot say much for the expression of her ladyship's mouth, which is a regular gape, like the clown's mouth at a pantomime : behind her lips we see a double row of teeth, one rank being in advance of the other, like a regiment of volunteers drawn up in line. The hind teeth are conical, but the front ones project, like diminutive tusks. I am nearly as certain as I can be that these are the teeth of a young cat-fish-a hideous fish that one sometimes sees hanging up in the fishmongers' shops in London. Her ears are very piglike, and certainly not elegant, and her nose decidedly snub. The coiffeur is submarine, and undoubtedly not Parisian: it would, in fact, be none the worse for a touch of the brush and comb. Mermaids in pictures generally are represented with a hand-glass and comb, 
as though they paid great attention to the toilet with the openly avowed purpose, as Tennyson te 1 in his "Confessions of a Mermaid," that-
All the mermen under the sea
Would feel their immortality
Die in their hearts for the love of me.

If I were a merman $I$ should decidedly not fall in love with any mermaid who was not a greut deal more particular in matters of hair-dressing than our friend under the glass case.

At the back of her head we see a series of nobs, which run down the back till they join with a bristling row of 24 spines-evidently the spines of the dorsal fin of the carp-like fish. The ribs in our mermaid are exceedingly prominent.

Tennyson gives an admirable description of the mermaids' submarine palace, and also of the social habits of mermaids in general :-

I would comb my hair till my ringlets would fall

Low adown, low adown,

From under my starry sea-bud crown

Low adown, and around.

And I should look like a fountain of gold

Springing alone,

With a shrill inner sound,

Over the throne

In the midst of the hall.

To judge, however, from the appearance of our Regent 
Street specimen, there must have been a rinderpest and famine price of provisions in general down in these splendid submarine regions, for our poor mermaid is very thin, seems half starved and terribly shabby, and altogether has a workhouse look about her.

In March, 1866, I received the following letter from C. H., a correspondent of "Land and Water :" "Captain Cuming, R.N., of Braidwood Terrace, Plymouth, has returned from Yokohama, bringing with him a great variety of curiosities. Amongst them is a mermaid. The head is that of a small monkey, with prominent teeth; a little thin wool on the head and upper parts; long, attenuated arms and claws, below which the ribs show very distinctly; beyond these latter the skin of a fish is so neatly joined that it is hardly possible to detect where the joint is made-in fact, where the fish begins and the monkey leaves off. The fish has large scales, spines on the back, a square tail, and appears to be a species of chub. It is quite perfect except the head, which only seems to have been removed to make the joint. Total length about sixteen inches; colour of monkey, dull slate; the fish, its natural colour; and the whole in excellent preservation."

I now give an engraving of this mermaid ; it is almost a counterpart of that in the possession of Farmer and Rogers.

Barnum has, I believe, a very good mermaid in his 
Museum, and he managed, he tells us, in "Barnum's Life, by Himself," to cause a great sensation with it, although it really is, as he himself describes it, "a diminutive specimen of an ugly, dried-up, blacklooking animal about three feet long. Its mouth is open, its tail turned over, and its arms thrown up, giving it the appearance of having died in great agony."

The difficulty was to get up the mermaid fever; by dint, however, of having "ten thousand mermaid pam-

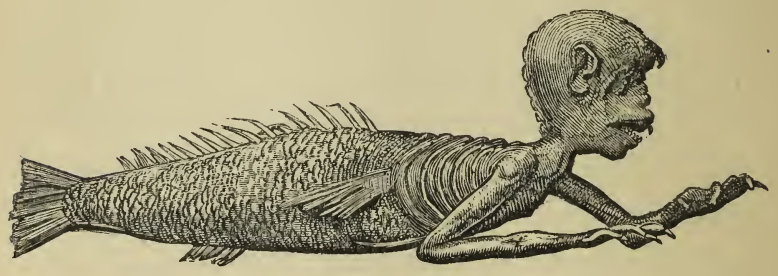

phlets" freely distributed, and several artfully-contrived inuendoes inserted in the local papers, as well as by erecting huge transparencies and ably-executed pictures, representing three mermaids, in the form of very beautiful young women with long flowing hair, and also a boatful of people looking at the mermaid sailing gracefully along the surface of the sea, he managed to create a sensation.

The mermaid painted in the pictures was, of course, 
the very specimen which could be seen on the other side of the "Pay here" door of the museum.

Anyhow, Barnum himself confesses in his book to have made during the first four weeks of the exhibition of his Fegee Island mermaid the sum of eight hundred and sixty-eight dollars, or about three hundred and forty-one pounds sterling. Bravo Barnum! 


\section{THE NONDESCRIPT.}

If Barnum managed to humbug the public so well, and to make such a sum of money as above related with his Fegee mermaid, I wonder what he would have done if he had had possession of my Nondescript, of which I now give a representation.

I am sorry to say I can get no history of this Nondescript. I first saw him in the shop of Mr. Wareham, china curiosity-dealer, at the corner of St. Martin's Court, Leicester Square. Mr. Wareham told me he had bought it at a sale from an old gentleman who prized it amazingly, and who in his lifetime valued it at the sum of $100 l$. It certainly is the most extraordinary-looking thing I ever beheld, and, indeed, I am rather offended with it, for when my friends come to see my private collection, I am sorry to say their attention is more taken with my hideous Nondescript than by other specimens which I flatter myself are valuable and interesting.

The Nondescript is about as big as a baby three months old, and, as a crusty bachelor friend of mine once said, "really very much like one." 


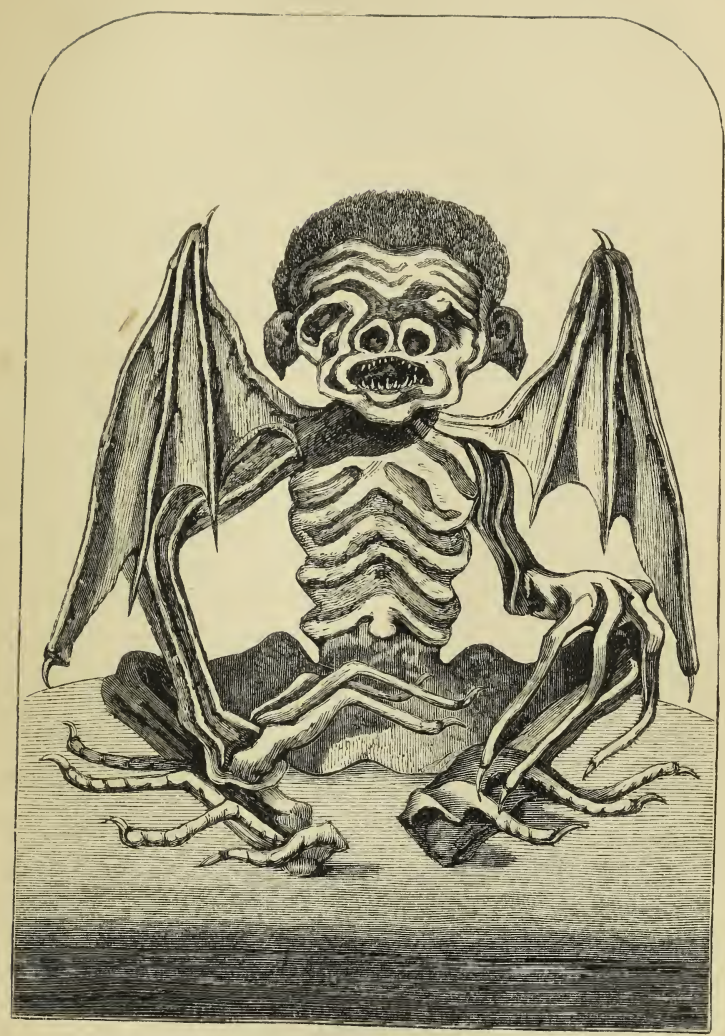

THE NONDESCRIPT. 
z 
He has wings on the top of his shoulder like the old army aiguilettes, and there are claws on the tips and on the extreme ends of each wing: these wings are so artfully contrived that one would believe they could be opened out and unfurled like a bat's wing at any moment the creature that carried it wished to take a fly either for business or amusement.

The arms are amazingly human-like, and look as though the dried skin had shrunk fast on to the bone; the legs also represent a similar appearance. The hands and feet are demon-like, and of a long, scraggy, merciless appearance, and each finger and toe is armed with a formidable-looking claw. The ribs project frightfully, as though the nondescript had lately been in reduced circumstances, and had been living for some time à la malcontent. The head is about as big as a very large apple. The ears project outward and downward, like those of an African elephant. The face is wrinkled and deformed; the nose like a pig's snout; the eyes like those of a codfish; the teeth exactly the same as those in the mermaid above described-double rows in each jaw, with protruding fangs in front; and surmounting this hideous countenance, a rough shock of fine wool. like hair, presenting the true prison convict crop, as though the Nondescript had been in trouble and had had "the key turned upon him;" and this I should think more than likely, for a more villanous-looking rascal I 
never beheld; a policeman would be justified in taking him up on suspicion alone.

Before this specimen came into my possession I was unable to examine it closely, as it was considered too valuable to be taken out from under the glass case. The moment, however, it came into my hands, I set to work to find out its composition. Everybody said there must be bones in the arms and legs and ribs. I soon tested this with a surgical exploring needle, but found no bone, nor anything like a bone, but simply soft wood, probably cedar. I made several incisions in the Nondescript's body, and found that the main portion of his composition was (like the legs) a light wood. The skin, as well as the wings, are made of a species of papier-mâché, most artfully put on in wrinkles, and admirably coloured and shaded to give the appearance of the dried body of some creature that had once existed either on land or sea-had been slain-and then preserved as a curiosity.

Although I can obtain no real history of my Nondescript, I fancy that he must be the handiwork of some ingenious Japanese. I imagine he is an ancient specimen, and has doubtless seen a great many curious adventures, if he could only tell us his history. $\mathrm{He}$ may possibly have been made by the very Japanese fisherman whose acquaintance Dr. Von Siebold, the well-known traveller, made in Japan, and of which he 
gives us an account in his work "On the Manners and Customs of the Japanese in the Nineteenth Century." Von Siebold says :-

This fisherman displayed his ingenuity by making money out of his countrymen's passion for whatever is odd and strange. He contrived to unite the upper half of a monkey to the lower half of a fish, so neatly as to defy ordinary inspection. He then gave out that he had caught the creature alive in his net, but that it had died shortly after being taken out of the water; and he derived considerable pecuniary profit from his devil in more ways than one. The exhibition of the sea-monster to Japanese curiosity paid well ; but yet more productive was the assertion that the half-human fish had spoken during the few minutes it existed out of its native element, predicting a certain number of years of wonderful fertility, to be followed by a fatal epidemic, the only remedy against which would be possession of the marine-prophet's likeness. The sale of these pictured mermaids was immense. Either this composite animal, or another, the offspring of the success of the first, was sold to the Dutch factory and transmitted to Batavia, where it fell into the hands of a shrewd American, who brought it to Europe; and there, in the year 1822-23, exhibited his purchase as a real mermaid at every capital-to the admiration of the ignorant, the perplexity of the learned, and the filling of his own purse.

Thus, then, we have good evidence of a regular manufactory for "Mermaids," "Nondescripts," and all such "Curioes," as my friend Robinson Crusoe would call them. The days of mermaids are now past, though the time was (judging from old books of natural history) when they were much prized and looked upon as a distinct kind of existing creatures.

There is an old proverb that there is "never smoke 
without fire," and I believe that the origin of the idea of the existence of mermaids and mermen was the fact of sailors having observed those curious semi-cetaceous creatures, Dugongs and Manatees.

The Indian Dugong (Halecore Dugang), is found round about the shores of the Indian Ocean and Ceylon; the Manatee is described by Mr. Wallace as particularly abundant in the lakes of the Amazon: these curious creatures, when diving and playing about in the water, have a very human appearance; judging from the skulls, the face is like that of a man with a long nose. Sailors, with their well-known ability of telling yarns to their friends at home, would not have much difficulty in converting a Dugong or Manatee into a real Merman.

A Dugong (Halecore Australis), is also found on the coast of Australia, and I learn from an article from the pen of P. L. Simmonds, Esq., editor of that most useful periodical the "Technologist," * that Dr. Hobbs, a practitioner of Moreton Bay, and health officer of Brisbane, Queensland, has brought Dugong oil into notice as a substitute for Cod Liver oil. This Dugong oil is described as equally efficacious as Cod Liver oil in the treatment of consumption, \&c., and it has all the therapeutic effects of Cod Liver oil without its nauseous taste and smell. $\dagger$ Thus, then, we practical folks of the

* Vol. I., p. 311. Kent \& Co., Paternoster Row.

† C. E. Batt writes, in "Land and Water:" "Dugong oil was 
present day no longer make a wonder of the mermen and mermaids, but simply harpoon them and boil them down for oil for the benefit of our patients and invalid friends and relations.

introduced into England five or six years ago, but its use has been almost entirely discontinued, possibly on account of its high price, 20s. per pint. Messrs. J. Bell \& Co., 338 Oxford Street, have a large stock of it on hand at the present time." 


\section{THE MERMAID-THE GIANT PIG-THE MONSTER OF THE DEEP.}

Of course I went to the Cattle Show (1867), and having seen the fat heasts adjourned to the shows outside, which, to me, is always great fun. In one of the shows I saw a sheep, in excellent health, that had a pair of extra legs growing out of his left shoulder; they did not touch the ground, and were not used for progression; but I have a live pig lately presented to me by my friend G. B. Bruce, Esq., that has eight feet, so that I can beat this six-footed sheep. Close by the sheep was a mermaid, one of the best I ever saw; it was about 3ft. long; the body was made (probably) of papier mâché, for I have dissected a mermaid. The tail was a hake's skin with the head cut off, the gill-part joined on to the mermaid's body. The teeth of the hake had been transferred to the mouth of the mermaid, and a pretty object she was lying in state in her glass case. The proprietor politely informed me that it was "diskivered when they pulled down the Old East India House, and is supposed to be three hundred years old; 
it is half a fish, and half a perfect human being." I have a merman at home, which I am willing to exhibit any day against this mermaid.

I then paid twopence to see the "Monster Pig," and he was indeed a monster. The handbill described him as follows :-

THE GREATEST WONDER OF THE WORLD.

To Be seen Alrve,

\section{A M O N S T E R P I G ! ! !}

FED ON BEACHE'S FARINACEOUS FOOD.

Stands $4 \mathrm{ft}$. 6in. in height, and 12ft. long. Weight, 200 st. Girth 8ft. 6in. He must be seen to be believed.

The monster is still growing fast, being in a healthy condition, and is considered by competent judges to make full 300st.; the owner challenges the world for its equal.

Proprietor of this Wonder:

Mr. J. CRuxton, Brown Jug Inn, Salop-street, Dudley.

This beast was more like a hippopotamus than a pig, and if I had not seen it I could scarcely have believed that a pig could have attained such a large size ;-whether Beache's food had or had not anything to do with it I of course cannot say. The pig was lying down on his side, and when I went to touch him he uttered a sharp grunt, like a disagreeable old gentleman disturbed in his after-dinner nap; I, nevertheless, managed to run a measuring tape down his back from the tip of his nose to the root of his tail, and found his measurement 
to be nine feet; his tail was very long and reminded me much of the stick of a hunting crop. Reader, measure out nine feet on the floor or garden walk, and you will have some idea of the size of this enormous animal. From the appearance of the pig I should say he was not far short of the weight described in the handbill. Some costermonger lads came in while I was in the show, "My eye, Jim," said one to his comrade, "what prime 'ams he would make. Why, he must be a misery to hisself."

I never saw another pig as large as this, but I have heard of one. When lately surveying an oyster bed at Poole Harbour, I found hanging up over the fire-place of a cottage an old-fashioned print, with the following particulars printed underneath: "The Yorkshire hog, $9 \mathrm{ft} .10 \mathrm{in}$. long, $8 \mathrm{ft}$. round the body, stands $12 \frac{1}{2}$ hands (4ft. 2in.), is four years old, weighs $1,344 \mathrm{lbs}$. or 160 st., at eight pounds to the stone, or 96 st. at $14 \mathrm{lbs}$. to the stone; he would have fed up to a much greater weight were he not so often raised up to exhibit his stature. The proprietors have gained by admittance to view him, in three years, 3,000l. Bred by Benjamin Rowley, Red House, near Doncaster ; fed by Joseph Hudson, on the estate of Colonel Beaumont, of Breton Hall." The date upon the picture is 1809 ; Pollard, Spitalfields, London. The present owner of the picture of this pig told me that it formerly hung in the "farmers' room," 
at the Bull's Head, Poole. It will be seen that the pig of 1809 coincides in weight, stature, \&c. pretty nearly to the pig of 1866 .

Next door to the "monster pig" show, I paid one penny to see "Wallace, the celebrated lion." This was a very handsome lion, about three years old, and a very pretty, healthy beast. He was probably bought cheap of some animal dealer, as lions have lately been a drug in the market, owing to the war in Europe, and the continental zoological gardens not buying anything. When I got inside the show the lion had changed from "Wallace the great" to "Wallace the little," and a man informed me that it was not the celebrated Wallace, but the grandson of that once famous quadruped.

A few yards off was another show. A man was standing on the top of a tub, by the side of a flaming gas-jet, vociferating at the top of his voice, " $\mathrm{Hi}$ ! hi ! hi ! walk in, ladies and gents; no deception, no 'umbug about this show! The last wonder of the world! The giant crocodile! the monster of the deep! Also the fat prize pig, which arrived too late for the cattle show! The gentleman on the right is the breeder of the pig. No extra charge, gents, for seeing the breeder of the pig. The crocodile is now a-feeding; the crocodile is now a-feeding! His food consists of wild rabbits, which he pursues round the cage. Challenge the world, gents! Half-price! half-price! Last night! Only 
one penny. Jim ! don't give the crocodile no more rabbits till the gent (myself) have paid his money." Uporı entering the show-a miserable place, like a bankrupt coal-shed-I saw a not very fat or monster pig reclining in the corner, but could not see the crocodile at all. At last I observed a large old egg-box, covered over with some old rabbit-netting, and in it lay, on the bare boards, the tamest-looking crocodile I ever beheld, about $8 \mathrm{ft}$. long. His eyes appeared hermetically sealed; his body, a dirty rust-colour, as though the dust had not been wiped off him for months, and his legs lay loosely alongside of him, as if they did not belong to him ; and I am not sure that he was not dead, or in a torpid state. By the beast's head was an old bullock's heart, quite dried up and mouldy, evidently doing duty for the wild rabbits, which, even after " the gent had paid his money," were invisible. 


\section{BLONDIN v. THE MONKEY.}

IN March, 1862, I witnessed and studied Blondin's wonderful feats of agility when acting at the Crystal Palace in the character of "The Ape," in the pantomimic drama of The Child of the Wreck. The activity and courage he displays are really something marvellous; but yet he partially defeats his own object, for his face, mischievous tricks, and the skin he wears, render him so like a real monkey, that people do not expect anything but excessive activity from the creature before their eyes. Were he to perform the same tricks in his ordinary exercising-dress, the effect would be much heightened.

There have, as we know, of late been great disputes relative to the difference between man and the monkey. Here, then, was a man acting the part of a monkey; and I was most curious to see how human anatomy would disport itself in the performance of feats peculiar to an animal whose habitat is in trees. On the whole, I felt some complacency as a homo at the 
marked difference between the two animals-human and non-human. Imprimis-a monkey being quadrumanous, or four-handed, always prefers to make progress (whether he be going slowly or swiftly) upon allfour members, and he never stands erect except on special occasions, and those rare ones : walking on two legs is not his natural mode of going. Blondin, on the contrary, being bimanous or two-handed, naturally elects the upright mode of walking; anything else is difficult to him; and when he has to advance or run away, he has to do it rather more like a man than a monkey.

When Blondin does walk upon "all-fours," his gait is very different from that of a monkey; he is obliged to walk upon the toes of his feet, the heels being erect in the air, and upon the palms of his hands, the thumbs being stretched well away from the fingers. The real monkey walks with the whole of the sole of the foot, heel and all, flat upon the ground, the great toe (or thumb) being separated from the toes. The four digits of the hand are parallel to one another; the very converse of Blondin's case. In fact, one of the great distinctions between a man and a monkey is, that the man has a thumb opposable to the top of each of the other digits; and upon this apparently insignificant fact is founded much of his superiority over all other animals. The monkey's thumb is not opposable to the 
ANATOMICAL CONSTRUCTION OF A MONKEY'S FOOT. 153

other digits; but, as if to compensate for this, his great toe takes the office of a thumb, and is of the greatest use to him in holding on to branches during the act of climbing. If a gorilla were to walk over Blondin's tight-rope, it would be seen by the spectators below that he would grasp the rope with his great toe. Blondin's anatomical construction will not allow him to do this; he walks, therefore, upon the sole of his foot, sustaining himself by the comparatively feeble grasp of the curve of the foot, and by a nice management of his centre of gravity, which gives him the appearance of walking so much from the hips. The human great toes can, however, be trained to grasp; and there is a poor man in London streets who gains his living by writing with his toes; still, no living man or woman will ever be able to vie with the monkey, as far as grasping with the great toe is concerned. Barefooted sailors come nearest to the animal in this respect. Watch a monkey go up a pole; you will see he places his hind-feet on the surface of the pole at a considerable angle to his body (which his anatomy enables him to do), and thus he ascends. Watch Blondin. His feet cannot be turned inwards like the monkey's. The complicated ligaments of the ankle, made to support an erect frame, will not allow it; he has therefore caused small wooden steps to be nailed on to his pole, which exactly resemble the bear's pole at the Zoological 
Gardens. In fact, Blondin goes up his pole much like our friend Ursa Major, to whom, as regards the structure of the foot, Blondin approaches more nearly than he does to the monkey. The bear is a genuine plantigrade, so called because he possesses a great facility, from the structure of the sole of his five-toed foot, of rearing himself up on the hind-feet. Blondin, therefore-unwittingly, no doubt-has arranged his climbingpole to suit his plantigrade structure.

A merry little child just in front of me at the Crystal Palace, at first was half-frightened at Blondin, thinking, in her infant mind, he was a real monkey; and when assured by her father that this was not the case, she wisely questioned his assertion by the observation : "Why, papa, he has not a mite of a tail." True, Blondin has no tail; and I would venture to ask the directors of the Crystal Palace what species of monkey Mr. Blondin represents-whether a monkey of the Old World, or a monkey of the New World. The monkeys of the New World have prehensile tails, a species of fifth hand; and, what is very extraordinary, the nonprehensile tailed monkeys, when feeling unwell, gnaw and devour the tips of their tails; whereas those of the New World, knowing the disadvantage that would thence accrue to them, do not gnaw their tails. Blondin would find it difficult to make an artificial prehensile tail, worked by human mechanism; he has therefore 
wisely dropped the subject, and we must assume that he performs in the character of an Old World monkey.

His pluck and courage in performing his jump of 120 feet are really marvellous. Ascending to a high platform on one side of the transept of the Crystal Palace, in front of the stage, he holds on to a rope fastened securely above, and letting himself go with a spring, swings right across the transept to the opposite side. It is as though you hauled up the great brass chandelier of Westminster Abbey into the organ-loft, and let it swing bodily up towards the reading eagle, under the centre of the great tower. I was curious to see how Blondin would land from his aërial journey, as his impetus would be too great to allow him to lodge on a platform. An eagle or other large bird, stopping suddenly in his flight, has his wings to help in bringing him up on a given point; not so Blondin: for the moment, he converts his body into a pendulum, a dead heavy weight, and his physical force, therefore, is greatly inferior to the dead weight of his body acting under the laws of gravitation. A monkey, in a natural state, free and wild in the forest, is no fool; he won't go and jump bang on to the trunk of a tree, a hard, firm, and inelastic substance-he is much too clever for that. He jumps on to a bough, which is elastic, bending, and pliant, and gives time for muscular force to overcome gravitating force. We don't often see 
monkeys wild in the English woods, but we do see a very monkey-like animal in every respect. The pretty little squirrel jumps not from trunk to trunk, but from bough to bough. Blondin has instinctively arrived at the same conclusion as nature did when she made the monkey and the squirrel, and he has therefore arranged a thick rope, which would represent a bough, in front of the platform, where he arrives at the end of his swing; in fact, the arrival-platform looks like a large cage with one thick bar. When about to start, he fixes his eye on the bar, and then away he goes with a most magnificent eagle-like swoop, as near flying as it is possible for human flesh and blood to arrive at: and when he feels himself near the end of his tether on the opposite side of the arch he has described, he stretches out his legs, and grasps in an instant the single bar of his cage.

This rope-bar being loosely fixed, "gives" to his force more or less: once having a hold with his legs, the rest is easy ; he poises himself a moment, holds on by one hand, and lets go the swinging rope which has carried him safely across with the other. This seems all very easy on paper, but I do not think it is very easy in practice, for the day I saw him his foot became entangled in the long swing-rope, and it was with difficulty he got it out again. I heard subsequently that a few days previously he had missed the rope on to which he 
swings: he was not quite quick enough to catch it with his feet, and away he went right back again into open space; for if human beings will convert themselves for the time into pendulums, they must submit to the laws which govern pendulums, and not human beings. Missing his hold, therefore, away he swung back again, but not with sufficient force to reach the place whence he started; he swung short of it, and back and back again, oscillating to and fro in mid-air for some minutes. It was impossible for him to recover sufficient force to reach either side; he was physically in the horns of a dilemma. There were only two ways of escape-one downwards, one upwards. Downwards he could not go; the drop on to the ground was too great; upwards he might go, as he still held on to the rope. There was no question that this was the only road open for him, so, therefore, up he went; up, up, till he should meet with a friendly cross-road which would conduct him home. On to one of the side-ropes he therefore transferred himself, and arrived in safety, amid the cheers of the visitors, at the platform whence he had started. The cool courage, determined pluck, and ready reasoning of the wonderful man never desert him. A slip of the foot, an unexpected movement of a rope, the fracture or semi-fracture of any part of his apparatus, may at any moment send him headlong and lifeless on to the earth beneath. We cannot, therefore, 
but admire him as a marvellous example of moral courage, and gigantic, yet elegant strength. A person fond of observing cannot fail to have arrived at the conclusion, that the occupation of an individual moulds his features. Place a soldier, a sailor, a bookseller, and a watchmaker side by side, and the difference in physiognomy will be remarked in a moment. We find that Blondin's features are moulded in a most peculiar cast; the very ideal of cool courage, iron determination, and pluck. May he live to a good old age, and escape the fate of so many of his predecessors, who attempt feats which the human frame is not by nature constructed to perform !*

* Reprinted by permission from "Chambers' Edinboro' Journal." 


\section{EAGLE MADE OF COPPER.}

IN October, 1862, I went to see an exhibition at 191 Piccadilly, of "An eagle made of copper." Before I visited it, I imagined that I was about to see some form of copper eagle such as we see used for "lecterns" or reading-desks in churches-which, by-the-way, are generally about as unlike the real birds as the most ingenious artificer could possibly invent or model.* I was, I may say, delighted and charmed at my first view of this Piccadilly eagle. It is not a "reading-desk eagle" at all, but a most beautiful model of the bird itself, of the natural size, in full plumage and health, thus described by a writer in the "Times": "It stands on the summit of a rugged and precipitous rock, in a hold and threatening attitude. With wings outspread ready for a dash at his quarry, or to withstand a human foe, the bird, with one claw advanced, firmly

* I must, however, make exceptions to this : viz. eagles carved out of solid blocks of oak by my friend the Rev. A. S. Baker, of Hargrave Rectory, Kimbolton. I have a photograph of one of hese beautiful lecterns, which is now in New College Chapel, Dxford. 
grasps with his talons the rocky ledge, while, with head protruding and open beak, he absolutely seems to scream warning and defiance. The keen eye peering from under the shadowing ridge of the skull, the rising feathers of the crest, the swell and ruffling of the muscular neck, form a picture of savage anger as true to nature as it is admirably conceived and executed." After gazing for some time in enthusiastic admiration of this most beautiful work of art, I proceeded, with the kind permission of Mr. Phillips, the maker of the eagle, to examine it minutely. Mr. Phillips explained to me that all before me (rock and bird) was made of copper. $\mathrm{He}$ set to work some six years ago-think of his patience!-in this way: He first made the body of hollow copper, and the bird then resembled a plucked fowl: he then proceeded to put the feathers on, instead of taking them off-what a difference in the facility with which these operations are performed! He obtained some slips of the finest copper from Japan (it is only allowed to be sent over from that country in slips), and he began to cover the bird feather by feather; each feather is, indeed, a study by itself, and he showed me the process of making them.

A real feather is placed on the table, a slip of copper is cut out its size and dimensions; it is then hammered into shape, and with peculiar graving tools is graved on the surface, and cut at the edges, till it is the exact 
model of the feather itself, each feather having to pass some twenty-six or twenty-seven times under the hammer and the graver, and having frequently to submit to great heat. Some of the feathers-their name is legion -are huge things, above 18 inches long, such as we see in the bonnets of Scotchmen; the quills of these are hollow, as in the natural state; others are as minute as the down upon a young chicken, or as fine as human hair-witness the feathers about the legs and over the eyes and nostrils of the bird; or, as the "Times" well puts it, "every one of the minute feathers which cluster round the neck, the fine hair-like down which runs from the beak to the eye, the soft cushion of plumage at the junction of the wings and body, are here separate, and can be each separately raised by the finger. The half-hairy, half-feathery legs of the bird are wonderful in the fineness of the down which overspreads them. The most extraordinary triumph of Mr. Phillips's skill, however, is shown in the extremely minute feathers which cover the frame of the pinions, and which conceal the fastenings of the large feathers forming the tips of the wings. It would be impossible to overrate this portion of the work, so numerous and so thick are the feathers, and so soft and deep is the effect produced."

I could not make out how it was possible for human hands to put all these feathers on to the copper body of a bird, and this in such beautiful and regular order that

SER. III.-VYL. II. 
Dame Nature herself could hardly surpass the work. Mr. Phillips, however, informed me that every one was soldered on, and that he began at the bottom, and soldered on the feathers one over the other.

Still, all this must have been a most laborious task: first of all, to make each feather; secondly, to fasten them on (many of them are so light that a breath of air would blow them off one's hand); and thirdly, to colour them. Now, unless some colouring process had been adopted, the copper eagle would have had a dull, and possibly a verdigris appearance. Mr. Phillips has, however, managed to overcome this difficulty. The mode of colouring which he has employed is a secret of his own, and was discovered by him in the course of executing his work. "It is an improvement on the old system, inasmuch as it supersedes the aid of a battery by a new process of what may be termed 'cold electrotyping.' Its chief advantage over the ordinary method consists in the variety of colouring on the same surface which it allows, and its superior economy."

Whatever the process may be, the result is most beautiful; there is a glitter and a gloss upon the bird only to be equalled by the plumage of a wild bird which is in the highest condition of health, and upon which the morning sun is pouring down its glorious rays. The plumage is very fine in the daytime; but at night, by 
the gaslight, which is placed above it, it is still more striking.

I wish I had space to describe the beak, the tongue, the roof of the mouth, the talons-all these are most life-like and true to nature : they are all of copper, as are the feathers. Mr. Phillips has taken for his model -a lesson to thousands of modellers-Nature herself. He has plucked the dead bird, feather by feather; he has studied the living bird in its most striking attitude and its most lustrous plumage; and he has produced a work which no naturalist, however sceptical, can find a fault in, and which is perfection itself.

I deeply pity, from the bottom of my heart, the poor "critic" who could write of such a work as this, "that it is good art, no amount of good-nature will enable him to say." He could have had no soul above heraldic dragons, mythical unicorns, pug-dogs in old china, conventional "coats of arms," lions, and impossible creatures, the products of the vain imaginations of those who fancy they can beat the glorious designs of all-wise Nature.

This beautiful eagle was, I believe, in November, 1865 , on exhibition at the Polytechnic.

There is a gigantic eagle made of zinc outside the shop of Mr. Gant, 254 Euston Road; it measures 17 feet from wing to wing, and is the work of an ingenious artist, Mr. James Durrant, the foreman of the establishment. 


\section{THE MARBLE LADY.}

Aвоuт five or six years ago an exhibition of a "Marble Lady" was opened at the Egyptian Hall, Piccadilly. The advertisement, in the usual flowing terms, described it as "one of the most marvellous of natural curiosities," \&c. "The figure of the lady, the bonnet, parasol, gloves, \&c., could be all seen exactly according to nature," \&c.

I inspected it immediately, and found the "Marble Lady" carefully covered over with a velvet cloth, and otherwise protected from injury, and I at once saw that it was simply a block of common black marble, about a foot square, in the centre of which there was imbedded a bit of fossil coral-like madrepore of a white colour. The exhibitor pointed out the dress (this antediluvian lady wore no crinoline), the parasol, gloves, bonnet, \&c.

The worthy man evidently was fully convinced of the reality of his prize, and I could hardly make up my mind to undeceive him. At length I ventured to express my opinion as to its real nature, at which he lost his temper and showed symptoms of unmistak- 
able anger; so I refrained from pressing my theory too far, as it was impossible to convince him of his mistake.

I hear that, in a cave somewhere in Wales, is shown a "Petrified Lady and her Dog." This is, probably, some stalagmite, formed by the water dripping from the roof of the cave. I should much like to know where this "Petrified Lady" can be seen. 


\section{THE GROWING PLATE.}

IN February, 1860, the following advertisement appeared in the "Times":-

GO AND SEE MR. HENRY HEALEY'S GROWING PLATE.-The most wonderful natural phenomenon of the age. The surface of an old china dinner plate, which has been in the possession of Mr. H.'s family for nearly 300 years, during which long period it has escaped the accidents of time, is now covered with eruptions of the purest crystal, resembling palaces, shrubs, flowers, \&c., of the most exquisite byauty. On the 8th of August, 1859, it was removed from the cupboard for ordinary purposes, when it was found to be covered with small eruptions, which created much surprise, and being preserved, has continued to develop its wonderful natural curiosities to the present time. The attention of antiquarians and men of science is expressly invited. Now on view, at 147 Oxford Street, opposite New Bond Street. Admission $1 s$.

I at once paid a visit to this wonderful plate. It was placed on a pedestal, with a glass shade over it, and a railing round it. At first sight, one would imagine that bits of common washing-soda had been scattered over the plate, and attached to it by gum; but, on closer examination with a magnifying-glass, I observed numerous excrescences of a whitish opaque substance, 
apparently growing or extending themselves out of the centre and rim of the plate, each supporting upon its surrface a portion of the actual enamel of the plate.

The largest eruption (if it may be so called) is about the size and shape of a fourpenny-bit, and it has raised up a portion of enamel above the surface of the plate to about the height represented by the thickness of a new penny-piece. In another place is seen a portion of enamel, also of an oblong shape, just being raised up above its ordinary level by the substance which is coming up from below. Numerous minor eruptions are also seen in the plate, all presenting the same appearance, viz., that of some substance taking its origin from the interspace between the upper and lower surfaces of the plate, each raising with it a portion of enamel corresponding in size to the extruding material.

I have not the least doubt that this is a natural production; that the material is of a mineral parasitic growth, resulting from some chemical decomposition of the clay of which the plate was originally formed.

My friend Warrington Smyth, Esq., of the Government School of Mines, has kindly written me the following opinion on this point :-

"I wish, for the sake of a solution to your question about the growing plate, you had been able to obtain a bit of that famous piece of crockery. But in the 
absence of opportunity for testing it, I have little doubt that its 'growth' must have been analogous to the fibrous shoots of ice which you may see on a frosty morning, bearing upon them bits of earth or little stones, which they have raised from the ground with the force developed in crystallisation. In the old workings of mines, the vigorous extension of acicular crystals of sundry salts (such as sulphates of alumina, of magnesia, or of iron) appear under very similar aspects, and often look exceedingly like vegetation. The efflorescence of salts in alluvial plains-as in Hungary and Egypt-is of the same kind. Now, the body of the plate contains alumina, sometimes magnesia, and sundry hypotheses might be started for bringing to these bases the necessary sulphuric acid for forming the fibrous crystals of alum, or of Epsom salt, which I fancy was most likely the 'growing' part of the plate, which carried upon its crest the fragments of the broken glaze.

\section{"Yours, very truly,}

\section{"Warrington Shyth."}

The proprietor told me that he had refused a cheque for a thousand pounds for his specimen. I therefore advise my readers to look in their china-closets, and see if any of their plates have grown since they were deposited there. 
I subsequently received the following kind note :-

“ 24 Lincoln's Inn Fields, London, w.c. "March 26, 1866.

"Dear Sir,-The growing plate. If it would interest you to see a much finer example of this very rare and curious phenomenon, I should be very happy to accompany you any day to the house of my relation, Miss Dodwell, of 21 Woburn Place, Russell Square, who, among her fine collection of old china, has a large tea-pot which has in the last year or two sprouted out in many places, as you have so well described as the case with the plate mentioned in the third series of your work. It is certainly worth examination. I have mentioned the fact to several collectors at the Society of Antiquaries, of which I am a fellow, but no one has met with a similar case.

"I remain, dear Sir,

"Yours very faithfully, "Geo. Chapman.

"F. T. Buckland Esq., M.D.,

" 156 Albany Street, N.w." 


\section{THE ANTHROPOGLOSSOS, OR MECHANICAL VOCALIST.}

UPON entering the room at St. James's Hall, in company with my friend H. J. B. Hancock, Esq., in order to examine this "wonder of the world," as the proprietor calls his mechanical vocalist, a paper was placed in my hands, stating that the Anthropoglossos would sing the following songs:- " The Dark Girl dressed in Blue," "Polly Perkins," "Annie Lyle," " God bless the Prince of Wales," \&c. \&c. We were informed that "the words of each song would be distinctly articulated, and that, never since the first sound of the human voice emanated from the earliest created of mankind, calling the oral mystery of sounding syllables that float upon the balmy airs of Paradise, until now, had aught been perfected which could approximate, in any degree, to the divinely-bestowed music of speech, and that the automaton head could rival Nature herself in its vocal elocutionary powers."

On entering the room we observed two huge wax heads at each end of a platform, ghastly and lifeless, 
like the heads of executed criminals ; and just behind a railing a gigantic wax head, which is evidently meant to be a portrait of Jullien, but which rather reminded me of the head of the giant Goliath, as seen in picturegalleries in the hands of David. As we entered, the head was singing "Annie Lyle," and the visitors were passing in single file in front of the railing, each stopping for a moment to look at the funnel which came out of the head's mouth, and whence the voice was supposed to issue.

"Uncommonly human, that voice," said I to my friend; "it is too good, and the thing has been overdone. There is, moreover, nothing metallic whatever about the voice, and I should not be the least surprised to hear it cough or sneeze; but, however, let us take our places."

As we advanced nearer the head, we observed that it was supported by two brass chains from above, and was in no way connected with any tube or pipe; but, like Mahomet's coffin, hung suspended in mid-air. The voice was supposed to come from the funnel which projected from the automaton's mouth. Beneath the head, however, was a sort of petticoat or frock, in which was contained the mechanism, which was regularly wound up, music-box fashion, when the sung was about to commence.

My friend, myself, and another friend who happened 
to be present, reasoned thus :-If the voice comes from the funnel, there must be a draught of air ; let us try the experiment. We therefore, having no light feather or other substance suited for the purpose, cut off the ends of the silk cord inside our hats, and with a penknife spread them out into the finest possible fibres, so that they would show the least puff of air.

My turn arriving, I marched boldly up and placed my "vocometer" (if I may coin a word) into the automaton's funnel; but no-not the least motion or draught of air was perceptible! Then followed my friend with his tuft of silk, and another accurate observer brought up the rear, each testing for themselves.

On comparing notes, we found that all three of our tufts of silk, when placed in the funnel, had been equally unmoved, though the head had been singing gaily all the time.

While we were talking, we heard a scuffle behind us, and also the sound as of a blow given. It appeared that a gentleman who had come to examine the instrument, had placed his pocket-handkerchief over a piece of perforated zinc which was let into the railing in front of the head, and that the person in charge of the head had taken the law into his own hands and struck out at him, accusing him of trying to turn the head round and injure it. 
Both my friends and myself formed our own opinions, which are decidedly not favourable to the metal mechanism of the voice we heard; particularly as, alas! The Anthropoglossos clipped his H's.

So much, then, for my experience of Exhibitions ! I have recorded, in the above pages, my experiences of the most interesting that have fallen under my notice during the last seven or eight years, though I have notes of many more. I trust my readers will be pleased with what I have written. I must now begin a fresh stock of notes, and shall be only too pleased if any of my readers will help me in my researches, either by giving references to printed accounts, ancient or modern, of curious exhibitions, or by telling me where they are actually to be seen. 


\section{ANTIQUITIES.}

\section{THE BONE-HOUSE AT RIPON CATHEDRAL.}

The object of my visit to Ripon Cathedral was to examine the collection of human bones which I had heard were preserved in a crypt under that cathedral. Such collections of human remains should be always regarded with a proper amount of reverence, considering their sacred nature ; but there is, nevertheless, no reason why we should not inquire into their nature and history, particularly when it is obscure, as is the case with these Ripon relics.

Leaving the ancient chapter-house, Mr. Benson, the civil and intelligent verger, conducted us to the crypt, which is underneath it. Unlocking the massive door, we at once beheld a "Golgotha." Bones, bones, bones everywhere; skulls, arm-bones, legbones; skulls of old men, young men, men in the prime of life, and of women and children; they were not, I am pleased to say, huddled together in an un- 
seemly and incongruous mass, but all stacked and arranged with decency and order. So many bones are there that the visitor cannot see the walls of the crypt, for against them is piled a wall of bones about six feet high, and four feet in thickness. Considerable taste (if I may use the expression) has been exhibited in the arrangement of the bones. In former times they were all scattered in confusion about the vault, but the old sexton of the parish, Mr. Dennis Wilson (himself now resting in the quiet churchyard), undertook, in 1843, much to his credit, the task of arranging them. He placed a row of skulls on the floor; then a thick row of arm and leg-bones with the round ends protruding; then another layer of skulls, and so on, till the space from the floor to the roof of the crypt was entirely occupied. I counted these skulls in their several compartments, and found that there were, from the wall to the outside of the stack, thirteen skulls in a row, and twelve in a row lengthways.

I remarked great variety in the conformation of the skulls. Some were long and narrow, others broad and massive; some were bullet-headed, some delicately shaped and classical; some presented the orbits of the eyes open and well marked, in others they were peeping and diminutive. In some the teeth were good, in others bad. Few of these bones or skulls presented any signs of decay, the vault being excessively dry. 
Then, again, the pillars of the crypt were ornamented with festoons of skulls. The arches from the pillars to the walls sustained rows of skulls; in fact, wherever there was a vacant space there a skull had been placed. One of the skulls, in particular, presented a highlypolished surface on the forehead. This I think can be accounted for by the fact that this skull happens to be just in the place most easily reached by the hand of the visitor, and the touch of the fingers of many visitors for years past has given it this peculiar appearance.* I am the more convinced of this because an enormously long femur, or thigh-bone, measuring $21 \frac{1}{2}$ inches, is kept separate from the rest, and is placed in the hands of the visitors by the verger for examination. This femur carries a bright polish, like a looking-glass. $\dagger$ The thigh-bone of my friend, M. Joseph Brice, the French giant (whom I have described in these pages), was $22 \frac{1}{2}$ inches in length: we may, therefore,

* The toe of a statue in St. Paul's Cathedral presents the same polished appearance. A couplet, written by the late Phil. Duncan, Esq., runs thus :-

"And the lips of the pilgrims devout Have kissed off St. Peter's great toe."

+ That bones will take a high polish is evident from the appearance of the bones used by cobblers in finishing off their work. I have in my collection a specimen showing this fact well. It is the metacarpal bone, about nine inches long, of a cow. I bought it of a weaver at Knaresborough, who told me it had been in use over 150 years. One half of the bone is entirely worn away; the whole surface presents a lustrous polish. 
possibly conclude that the man of whose body this Ripon bone formed a part approximated to the same height as M. Brice, namely, 7 feet 2 or 3 inches. I also observed among the arm and leg bones several cases of fracture, and subsequent reparation, showing that surgery in some part of Ripon's ancient history was not at its maximum of perfection.

I was curious to arrive at some sort of idea of the number of human beings represented by the bones in this crypt. Each person must of necessity have had a skull, so that, by counting the skulls, I conceived I might get at an approach to the number of people whose remains were deposited in this crypt. We accordingly counted the skulls in their length, breadth, and thickness ; measured the compartments, length of the crypt, $\& c$. , and, by a calculation, we made out that there were the skulls of about 9,912 in the bone-stacks in this crypt. Not all the bones of these individuals were, of course, there, as there would not have been room for them. All other bones of the skeletons, save and except the skulls and the arm and leg bones, the verger had buried in the churchyard at the time he stacked them. "But you must go on with your calculations, sir," said the verger. "Why so?" I asked. "Because," said he, " underneath the floor of the crypt is another mass of bones, buried under the ground on which you now tread; they also are stacked, and are four feet in thick-

SER. III.-VOL. II. 
ness, and are spread all over the vault of the crypt." What a vast assemblage of the mortal remains of human beings are, therefore, collected together! I leave it for the reader to calculate the sum.

It is indeed a curious thought when we consider the vast quantity of human bones which must accumulate every year in our grave-yards. I well recollect as a lad being taken by my father the dean to call on the late Duke of Wellington. Dr. Buckland, said the duke, I want to know from you as a geologist, what becane of the bones of all the people who were drowned in the deluge ; - a pertinent question, probably suggested to the duke's mind by having seen battle-fields covered with human bones. I forget my father's answer, but of course it would be that bones exposed to alternations of frost, heat, and wet soon decay, and falling to pieces are seen no more.

I was naturally most anxious to obtain correct information as to how and when these Ripon bones were collected in the place where they are now deposited, and was most fortunate in making the acquaintance of Mr. Harrison, of Ripon, whose authority on all archæological matters in the neighbourhood is undoubted. He tells me that they were discovered in a confused mass, thrown into a vacant space between two buttresses of the cathedral; that they were removed from thence into the crypt, where they remained un- 
heeded and disregarded till the sexton undertook to arrange them. Now comes the question as to how came they between the buttresses? In former times the various villages and hamlets in the neighbourhood of Ripon had no burying-grounds attached to their parochial chapels, but it was the custom of the inhabitants to send their dead for interment in the precincts of the cathedral. Hence, in course of time, the ground became replete with human remains, and the grave-diggers, when making a new grave, were obliged to remove large numbers of human bones, which were placed between the buttresses, and there accumulated for centuries; some of the bones may be, therefore, possibly as old as Wilfrid, Archbishop of York, to whom about the year 661 (Wilfrid died 671), Aldfrid, King of Northumbria, gave the monastery of Ripon, previously founded by Eata, Abbot of Melrose.*

* P. S.-I regret to learn that this crypt is now (September, 1867 ) closed to the public by order of the local authorities. 


\section{ANCESTRAL SKULLS.}

There is a curious collection of human skulls and bones in England, which is well worthy of a visit.

I heard of these quite by accident. When staying at Folkestone, I thought I would pay a visit to Hythe, and look at the musketry practice. I never, however, got far enough to see the shooting, as something much more to my taste attracted my attention on the road.

On my journey to Hythe from Folkestone, according to my usual custom, I inquired of the omnibus-driver whether there was "anything curious" to be seen at the place we were going to.

"Why, yes, sir, I've heard say that there is a wonderful sight of Christians' bones in the church crypt; some of the regular old-fashioned sort of bones, sir, all stacked in a row like fire-wood for burning at Christmas time."

The moment the omnibus pulled up at the White Hart, Hythe, I hunted up the parish clerk, who confirmed the driver's story, and obligingly walked up with me at once to the church, which is called Saint Leonard's. 
This bone crypt is situated at the east end of the church, but is not below the level of the earth. When the guide opened the oak doors I saw an immense stack of human bones, piled up in regular order, and evidently with the care always due to the sacred remains of our fellow-creatures. The walls of the pile are formed by the rounded ends of arm and leg bones, as in the Ripon collection, while every here and there a skull is built into the stack ; and these emblems of mortality grin a ghastly grin at the astonished visitor, before his eyes are quite accustomed to the sudden change from the bright sunlight outside.

The history of these bones is very remarkable. They are said to be all that is now left of an army of our forefathers, the good old Anglo-Britons, and of a horde of savage, invading Danes; the bones of deadly foes now lie mixed together, and the men that some 1016 years ago were opposed in deadly strife, having yielded alike to the all-conquering arm of death, silently repose, gradually crumbling into the dust from whence they were taken.* There is a framed placard upon the wall

* My friend Captain Salrin tells me the following curious story:-

About the time Dr. Whitaker wrote the history of Craven (a district in Yorkshire), he and some of his antiquarian friends opened several ancient graves at Bolton Abbey and other places. At Skipton they peeped into the tomb of Admiral Lord Clifford, and as I have been told a curious circumstance 
of the crypt, which, in the following words, tells us the particulars relative to this curious collection :-

"In the reign of Ethelwolf, A.D. 843, the Danes landed in Kent, near to Hytha (Hythe); they proceeded as far as Canterbury, a great part of which they burnt. At length Gustavus, then governor of Kent, raised a considerable force to oppose their progress, and after an engagement, in which the Danes were defeated, he pursued them to their shipping on the sea-coast, where they made an obstinate resistance. The Britons, however, were victorious; the slaughter was prodigious, not less than 30,000 (?) being left dead on the field. After

connected with it from one present on the occasion, viz. the late Mr. George Walker, of Killingbeck Hall, near Leeds, I think it worthy of record. Mr. Walker told me they found the earl, who had been embalmed, quite perfect, and dressed in the costume of the day, in high crowned hat, plume, frill, \&c.; but no sooner was he exposed to the air than the remains began to shake, and in a few seconds all gave way; and this extraordinary sight (bringing one back to the days of Elizabeth) collapsed into dust. Mr. Walker, who was a person of great observation, a naturalist, a sportsman, and an artist, was very fond at this period of making pedestrian tours through the country, and he informed me that the day after his curious introduction to the earl, he visited Chatsworth, and whilst looking through the pictures, he had the pleasure of putting the housekeeper right, for she had got her story wrong about the portraits, and pointed out one which she said was the identical Admiral. Upon this, he said, "I must correct you (pointing to another picture): this is the Admiral, for I saw him only yesterday, and if necessary I could swear to him." 
the battle the Britons, wearied with fatigue, and perhaps shocked with the slaughter, returned to their homes, leaving the slain on the field of battle, where, being exposed to different changes of the weather, the flesh rotted from the bones, which were afterwards collected and piled in heaps by the inhabitants, who, in time, removed them to the vaults of one of the churches at Hytha (now Hythe). This is supposed to be the only genuine description, and is extracted from a very ancient history of Great Britain."

Mr. Tournay, builder, and clerk of the church, informed me that the bones used to lie scattered in disorder till about twenty years ago, when they were arranged in the present decent order.

This great battle of Hythe was fought on the seashore, which just here is very level, and for this reason has been chosen, in modern times, for rifle practice. There is a range of hills about half a mile from the sea, and a better locality for a battle-field I never saw. A short time ago a sham battle between the regiments stationed at Shorncliff camp took place, under the inspection of H.R.H. the Duke of Cambridge, near the very spot where the bones were found, and served to realize to the present inhabitants of Hythe the strife long long ago between their forefathers and the Danes. The house of the present mayor of Hythe is built upon part of this battle-field, and in digging the founda- 
tion of it many bones were discovered, whence a name is now given to this house, more expressive than classical, viz., "Marrow-bone Hall."

On each side of the door of the crypt were arranged rows of skulls, about 250 on each side. (In the great heap there must be the remains of at least 2,000 individuals.) The skulls on the shelves were loose, and could easily be examined; they are said to be the skulls of Ancient Britons and of Danes, and the distinction between them is marked. The skulls of the Britons are those of persons who in life must have been noble-looking fellows. They are much rounded, high at the top, broad at the forehead, presenting a cavity that must have contained a large and intellectual brain. The brows are large and well-formed, the cheek-bones massive, and the jaws powerful, but by no means brutish. One of these heads is placed on the table, and is much polished by the handling of visitors. It ought to have belonged to a chieftain, as courage, stern determination, and firmness, are all prominent in its form. A finer specimen of a well-formed human skull I never beheld; and the visitor need but examine the shelves to find many others nearly as well developed.

The Danish heads are of a different shape: they are long and narrow; the face must have been small, and, if I mistake not, the eyes in life diminutive, and rather sunk into the head; the jaws project downwards and 
forwards, as we see in many savages of the present day.* Upon one of these skulls I found some short hair still remaining, which, when examined with a glass, I found to be of a red fox-like colour, and probably Danish, for even now the Danes are, I understand, as a rule, a redhaired race.

The teeth remaining in the skulls are in excellent order; and I observed but very few symptoms of disease about them, so that tooth-ache could not have been common in those days-a very different state of things from what we find among soldiers of the present day. The teeth of the Ancient Britons were worn away, from the summit downwards, like the teeth of herbivorous animals. I have observed this trait very commonly in the skulls of the former inhabitants of England, espe-

* I feel convinced that sculptors would do well to practice restoring the features by means of modelling clay to skulls. The student might take a modern African skull, and on it mould the features of the negro; the same with a European or Mongolian specimen, \&c. Practice in observing the relations of the muscles of the face to the bones to which they are attached, would in time enable him to restore to our view the features of the Saxons, Romans, Danes, and others, from the skulls found in various crypts, \&c. I have made friends with the "King of the Mud Larks," an old man who brings bones from the bones collected by the men who dredge the Thames in ballast barges. "The King" has brought me a wonderful skull, that eren now seems to have a frown on it. It was dredged up off Battersea, and is probably Roman. I should much like to see the features in this skull restored. 
cially in the skulls of monks, and imagine it to proceed from the fact that the food used was principally hard peas, beans, etc., and these wore the teeth down like mill-stones.*

The skulls were mostly those of adults : in the armies they had only able-bodied men for soldiers: only one skull of an old man did I find, though, alas! four skulls of boys, about twelve years of age. Two of these were British and two Danish. Might not these be the skulls of the drummer-boys of the camp? If they had not drums in those days they might have had something analogous to drums; or these boys might have acted as assistants to carry the men's spears, weapons, or provisions.

The fighting in those days must have been regular hand-to-hand work, downright fighting, for upon many of the skulls we found wounds, particularly about the forehead and sides of the head. In a medico-legal point

* My friend J. K. Lord, Esq., in his capital book "The Naturalist in British Columbia," mentions a most interesting fact as regards the wearing down of human teeth. He says, when describing the Indians catching salmon at the cascades in the River Columbia :-

During the drying, siliceous sand is blown over the fish, and of course adheres to it; constantly chewing this "sanded salmon" wears the teeth as if filed down, which I at first imagined them to be until the true cause was discovered. I have an under-jaw in my possession whereon the teeth are quite level with the bony sockets of the jaw, worn away by the flinty sand. 
of view I should have no hesitation in asserting that these wounds had been inflicted by some heavy, but not over-sharp weapon, just such as these warriors of ancient days were likely to have used. Some of these arms were found with the bones, but I was not fortunate enough to obtain a view of them. One of the skulls presented a depressed hole in the forehead, which might have been made with a round stone from a sling; for the sling was used in those times, before the invention of guns and cannon, and a very formidable weapon it was in ancient warfare, as we may learn from several passages in sacred writ.*

The arm, leg, and other bones were those of persons in full health of body at the time of death. Only one bone did we find that at all approached to a diseased state, and that was the tibia or shin-bone of a bandylegged person. Perhaps his bandy legs did not allow him to run away fast enough, and so he got killed in the general mêlée.

Most of these bones were in excellent preservation, and they must have formed the frames of muscular and strong soldiers, for the points where the muscles were inserted were very prominent and roughened,

* I hare a skull of a trooper found near Banbury. He was probably one of many killed by Ireton's Dragoons after the battle of Edge Hill. There was great swording from Keinton to Bourstall. The mark of the sword-cut is still visible. 
which is always the case in those who lead a life of severe bodily labour. There must have been some tall men, possibly Life Guardsmen of the period, who fell in this memorable battle, for one of the thighbones which we measured must have supported a frame nearly seven feet high. These giant bones are, however, rare compared to numerous shorter bones; and I doubt whether the former inhabitants of this island, judging from their bones, were taller and more athletic than the majority of its inhabitants at the present day. A friend of mine, a young man six feet two, and stout in proportion, could find but one or two suits of armour in the Tower that would fit him comfortably.

There is a notice in the crypt, "Please do not write upon the skulls; " but I do not consider this a sufficient intimation why I should not write about the skulls, for the benefit of those who take interest in matters relating to the history of the ancient inhabitants of this island.

Craniologists would, possibly, have a different story from the above to tell, as regards the nationality of these skulls. I tell the story as it was told to me, and describe simply what I saw. I shall be very glad to know the opinion of other scientific men relative to the skulls both at Hythe and at Ripon. 


\section{ROTHWELL BONE-HOUSE.}

Since the above was published, I have received the following correspondence, for which I feel most obliged :-

"Viscountess Hood presents her compliments to Mr. Buckland, and having just read with much pleasure his 'Curiosities of Natural History,' especially the account of the Bone-Houses at Ripon and Hythe, she is anxious to tell him, in case he is not already aware of the fact, there is a most curious collection of bones, all adult males, in a crypt in Rothwell Church, Northamptonshire, discovered 100 years ago, and no light whatever has been thrown upon how they came there; amongst them Lady Hood believes there is a skull of a negro.

"Barton Seagrave, Kettering."

Flitton Vicarage, Ampthill, September 10, 1866.

Dear Sir,-I am reminded, by your account of the extraordinary collections of Bones at Ripon Cathedral, and at Hythe, of a similar collection at Rothwell in Northamptonshire; as this seems to have escaped your notice, I make no question that I 
shall be excused for directing your attention to it. Many years ago now, I remember forming one of a small party engaged on purpose to visit these remains. On reaching the village we proceeded to the church, and were conducted to a crypt, under the south aisle, access to which was by a nurrow circular staircase in the south porch. This crypt appeared to occupy the whole extent of the aisle above, and might be between 40 and 50 feet long by about 8 or 9 in width, and about 7 or 8 feet in height to the crown of the vault: with the exception of a narrow gangway, the whole of this area was filled from the ground nearly to the roof, with an immense collection of skulls and thigh-bones, arranged in the orderly and decent manner that you notice with so much approval at Ripon and Hythe. I remember at the time, being fresh from the perusal of Pritchard's book ("Natural History of Man," \&c.), being struck with what I conceived to be marked differences of craniological structure in these remains, and I came perhaps too hastily to the conclusion that the two opposite sides of the gangway represented distinct races: some of the skulls had been evidently perforated with warlike weapons, and the general impression in our party was that the collection before us was the gathering of some terrible battle-field in the vicinity. One almost always has to regret, on these occasions, not taking the trouble to note down particulars as to number and measure; being in want of a footrule I recollect applying a pocket-telescope drawn out to its full length, to some of the thigh-bones, and found that in several instances it barely reached the size of the specimen; now the telescope in question is about 18 inches long, and therefore we may infer the stalwart condition of the original possessurs of some of these fragments; indeed, the sexton told us that a very remarkable thigh-bone had been bagged, or rather boned, by some curious visitor, and very probably other distinguished specimens had been lost in the same manner. As to the probable number of individuals to whom these dead bones belonged while in life, I have little or nothing definite to say; there appeared to be no smaller bones than crania and femora in this collection, and therefore the aggregate amount would be considerable. I re- 
member satisfying myself, no doubt under the overwhelming impression of the first coup d'œil, that there could not be less than 15,000 or 20,000 representatives of humanity here stacked together, certainly 10,000 or 12,000 would seem a moderate estimate: of course the popular calculation vastly exceeded the largest of these sum-totals. What is extraordinary, is the fact that no report or tradition in the village or neighbourhood connects this accumulation of bones with any event having occurred in former times: no one could give any information on the subject, and I have never met with any account of Rothwell that even mentioned the "bones" at all: in fact, I believe that until late in the last century, the very crypt which contains them was itself unknown, and was then only discorered in consequence of an attempt to dig a grave in the south aisle, when both the crypt and also the little staircase leading to it, which had been walled up on the porch side, were bronght to light. Since the discovery, which is not yet I fancy 100 years old, the stack of bones has subsided a good deal from natural decay and other causes, and whereas formerly it may have reached the ceilin $r$ of the vault, it has now settled down to about five feet or less; when I saw them the height was just equal to my chin or thereabouts, and I could comfortably survey the superficial $\in x-$ tent of the range. I should remark that we did not require any candles, as the crypt is lighted by several eyelet holes from without. This church of Rothwell is very interesting on other accounts, and well worth a risit. Indeed, it figures in Bloxam's little book on "Gothic Architecture" as an illustration of the transition from Norman to Early English. The village was formerly of more importance than it is now, and has some curious remains of a market house begun in 1577 by Sir Thomas Tresham, but never finished. There is also an old hospital near the church, founded in 1590, for 18 old men. There is a tradition that the town never recovered from the derastation of a great plague which visited it in the 17th century; but a plague, however destructive, would never account for "the bones" in a population of 2,000 , or even ten times the number. Rothwell, or Rowell, as it is commonly pronounced, is a three 
hnurs' ride on the Midland Railway from King's Cross, and a four mile drive from Kettering station.

\section{Yours faithfully,}

Alfred Brown.

\section{F. Buckland, Esq.}

"You mention in your book large quantities of human bones. If you ever go to Nottingham you may see (or might have seen) a very large quantity in the southwest quarter of St. Mary's churchyard. There is, or was, a trap-door, and below that a ladder, which I went down, and landed on a considerable heap of bones, thrown down the hole, I suppose, when taken out of the graves. At the bottom I found a long cellar, divided into compartments, or bays. The thigh and arm bones were piled up in front to make a wall, and the others thrown in behind. There must have been the bones of many thousands of persons, I should think, but as it must be over forty years since I saw them, I have not a very clear recollection as to the quantity.-SAmuel Surth."

The Rev. Henry Heming also writes to tell me that there is a collection of human bones in North Hants, principally skulls with arm and leg bones, stacked up like wine bottles in bins; they were discovered about a century ago.

I regret I have not as yet had time to examine these Rothwell, Nottingham, and Hants bones, but hope to do so some day. 


\section{MORTUARY CHESTS AT WINCHESTER CATHEDRAL.}

When I was at Winchester school, the custom was for all the boys to attend the service in the cathedral on Sundays, and seats were provided for us just outside the altar railings. On each side of these seats is a wall, and on the top of the wall are six most remarkablelooking ancient wooden chests surmounted with crowns, and upon these mortuary chests Latin inscriptions. As a boy I longed to have a look inside these chests, but never got a chance. Since then, some three years back, I had an opportunity of looking into them. I found that they really did contain human bones, mostly arm and leg bones, and if I recollect rightly no skulls. The bones were very dusty, but hard, dry and firm, and did not show the least symptoms of decay.

These bones are said to be the remains of kings and princes, but I much question their authenticity. The Dean and Chapter would do well to allow a competent body of medical men and antiquaries to examine them and give their opinion on the point, as well as to see to SER. III.-VEL. II. 
the condition and further preservation of these relics. I learn from "The Antiquities of Winchester" * that these remains were collected by Bishop De Blois, in the twelfth century, and deposited in leaden coffins over the Holy Hole, probably in the same situation which these chests occupy. When the choir was rebuilt, in the beginning of the sixteenth century, it was necessary to remove these coffins, which, being inelegant and numerous, Bishop Fox caused six wooden chests to be made, and placed in their present position.

The first chest from the altar, on the north, contains the skeleton of the first Christian king of the West Saxons, Kynegils, founder of the cathedral, and of King Ethelwulf, here called Adulphus, the father of the Great Alfred, once a sub-deacon of this church, and its great benefactor. It is inscribed on one side-

REX KYNGILS. OBIIT A.D. 641 .

King Kyngils. Died A.D. 641 .

And on the other-

ADULPHUS REX. OBIIT A.D. 857 .

King Adulphus. Died A.D. 857.

with this epitaph-

KYNGILSI IN CISTA HAC SIMUL OSSA JACENT ET ADULPHI,

IPSIUS FUNDATOR, HIC BENEFACTOR ERAT.

The bones of Kingils and Adulphus lie together in this chest;

The former was the founder, the latter the benefactor of this church.

* Published by W. Savage, 97 High Street, Winchester. 
The second chest on the same side contains two skeletons, one of which is Kenewalch, here called Kenulph, the son of Kinegils, and the real builder of the cathedral at the Saxon conversion; the other is that of the founder of the English monarchy, Egbert. This chest is inscribed-

KENUlphUS REX. OBIIT A.D. 714.

King Kenulph. Died A.D. 714.

And-

EGBERTUS REX. OBIIT A.D. 837.

King Egbert. Died A.D. 837 .

The epitaph-

HIC REX EGBERTUS PAUSAT CUM REGE KENULPHO.

NOBIS EGREGIA MUNERA UTERQUE TULIT.

Here king Egbert rests, with king Kenulph.

Each of them bestowed great benefits upon us.

The third chest contains part of the mingled remains of various persons, the other part being deposited in the corresponding chest on the other side. These are the bones of Canute, the Danish king; of his queen Emma, the fair maid of Normandy ; of the tyrannical Rufus; of the Bishop Alwyn; and of the prelates Wina and Stigand. These remains had become so intermixed from the time of De Blois, that their identity was doubtful, which accounts for their disposal by Fox in these chests. The inscription on one side of the chest before us is :- 
196 the mingled remains of Canute, rufus, etc.

IN HAC ET ALtera E REgione Cista RELiquiaE SUNT Canuti et rufi, Reguil; endae, reginae; Wynae et ALWINI, EPISCOPUMI.

In this chest, and in that opposite to it, on the other side, are the remains of Canute and of Rufus, kings ; of Emma, queen; and of Wina and Alwin, bishops.

On the opposite side-

HAC IN CISTA, A.D. 1661, PROMISCUE RECONDITA SUNT OSSA PRINCIPUN ET PRAELATORUI SACRILEga barbarie DISPERSA, A.D. 1642.

In this chest, 1661, were promiscuously laid together the bones of the princes and prelates, which had been scattered about by sacrilegious barbarism in the year 1642 .

In the middle chest, on the south, lies the mortal part of Edmund, the eldest son of Alfred, whom his father caused to be crowned king in his own life-time; but the son dying before the father, and previously to the latter's resolution of building the new monastery, for the burying-place of his family, he was interred in a spot in this cathedral, whence his bones were removed to the present shrine, which bears on each side the following inscription :-

EDMUNDUS REX. OBIT A.D.

King Edmund. Died A.D. ....

QUEM THECA HAEC RETINET EDMUNDUM SUSCIPE, CHRISTF, QUi, VIVENTE PATRE, REgIA SCEPTRA TULIT.

Him whom this chest contains, and who swayed the royal sceptre while his father was yet living, do thou, O Christ, receive. 
The sixth and last chest contains the relics of King Edred, the youngest son of Edward the elder, who was buried in the cathedral by his friend St. Dunstan. The title and epitaph are the same on both sides-

EDREDUS REX. OBIT A.D. 955.

King Edred. Died A.D. 955.

HOC PIUS IN TUMULO REX EDREDUS REQUIESCIT

QUI HAS BRITONUM TERRAS REXERAT EGREGIE.

The pious Edred rests in this tomb, who admirably well gorerned this country of the Britons.

N.B.-In transcribing the foregoing inscriptions all the abbreviations have been supplied. 


\section{SKULL FOUND AT ALDERSHOT CAMP.}

WheN doing duty as medical officer in charge of the 2nd Life Guards in Aldershot Camp, in June, 1861, our Regimental Quartermaster, Corporal-Major Waite, knowing my love for curious things, was good enough to bring me a copy of the "Aldershot Gazette," in which I read the following:-

" Remarkable Discovery at Aldershot.-On Monday morning, some workmen who were removing earth near the Royal Horse Artillery barracks, South Camp, Aldershot, discovered the skull of a person who had evidently met with a violent death many years ago. The skull, which appeared to be that of a full-grown man, was pierced at the top with a gunshot wound, and there was a slug wound in one of the eyes, with the slug remaining in it. A part of the jawbone seemed to have rotted away, and a surgeon gave it as his opinion that the skull had been in the ground twelve or fourteen years at least. The present site of the camp was a wild 
heath a few years ago, and the neighbourhood is associated with many tales of the exploits of highwaymen. No other remnants of a human being, except the skull, were found by the workmen, and that has been placed in the hands of the police, who are instituting inquiries respecting it."

I immediately got on my horse and rode away up to the South Camp, where I found the good folks in a considerable state of excitement about the matter, and this made me more anxious than ever to see and examine the skull. At last, by the kindness of a brother Medical Officer, I was enabled to examine it, and make inquiries about it.

It appeared that some of the troopers of the Horse Artillery, when hunting for rats at the back of their stables in the camp, turned up this skull; they could not imagine how it got there. The fact was, therefore, reported to the police, and, according to the "Aldershot Gazette," "the skull was taken to the Coroner." There was a hole on the top of the skull, which was made with the point of a pitchfork by the sergeant who found it; there was, besides, the mark of a cut or wound in the bone over the right eye---this wound had healed over, and must therefore have been inflicted some years before death; there was also a small leaden bullet, such as would be fired from a revolver, still fixed in the bone of the outer wall of the orbit of the left eye. From the situation of this leaden 
bullet it was probable that the shot had been fired from behind the victim.

Of course everybody said there had been a murder committed at some time or another; and following the hint thrown out by the "Aldershot Gazette," the prevailing idea was, that some unfortunate traveller had been shot by a highwayman upon Aldershot heath in the "good old days" when highwaymen abounded on this abominable desert heath-I call it abominable because soldiering and perpetual Regimental "Fielddays" in this bleak wilderness is not at all suited to $m y$ taste. Anyhow, there was a considerable " talkee, talkee" about the skull_murder-pistols—Dick Turpin -highwaymen, \&c. There was, however, an awkward little fact that nobody could account for, viz., where was the rest of the poor murdered man's body. Only the skull was found; what could the highwayman have done with the body of his victim? Nobody could explain that; yet here was the skull, and the skull only, to be accounted for. At length (and I was really in one way very sorry for it, for it stopped all the speculations, the inquiries of the sagacious police, the Coroner's inquest, \&c., \&c.) the mystery was explained in the most prosaic manner possible.

It turned out that a sergeant of the Chestnut troop of Royal Horse Artillery had received the skull as a present from the servant of Captain - - who had brought 
it from the Crimea. The sergeant's wife did not approve of the skull being in such close proximity to her domestic arrangements in her husband's hut while in camp, so in order to put it out of the way of his better half, the sergeant buried it about one foot deep in the ground in the rear of the troop stables. He intended, I believe, when the time came for the regiment to move from the camp into town quarters, to have dug up the skull and taken it with him. However, fate decreed otherwise.

If the sergeant had not very properly and creditably come forward to explain how this skull came to be deposited in the place where it was found, it is probable. that much more would have been said and done about it than was said and done.

I was very anxious to obtain the skull, which had caused so much discussion in the camp, and the brother Medical Officer above-mentioned was good enough to give it to me. The sergeant, having had more bother with it than was agreeable,-first with his wife, and then with the stir and fuss made among the soldiers about its discovery - was pleased enough to get rid of it.

It is now on the shelves of my museum at Albany Street; but I am sorry to say I have lost the bullet out of it.

As soon as I had an opportunity, after returning from 
the camp, I took it to the Royal College of Surgeons, and compared it with the skulls in the ethnological section of this magnificent collection. It appeared to me, and to other medical friends who were with me, that this cranium found at Aldershot must be, as it is reported to be, that of a Russian. The peculiar round shape of the head, the formation of the cheek-bones and forehead, as well as other points, led us to this conclusion. It is, moreover, a smaller head than the generality of the European type; this may or may not be an individual peculiarity of the cranium; anyhow, all the Russian helmets I have seen seem to have been made for people with small heads.

Although this wonderful skull turned out after all to be the skull of a Russian brought from the Crimea, the matter set us all talking about highwaymen, \&c. ; and in course of conversation, an Officer told me of a discovery of human remains which it is not at all improbable were really those of some unfortunate murdered traveller. During some excavations in front of the south cavalry barracks at the camp, the workmen came upon a mass of lime three or four feet beneath the surface; and in this lime were concealed the remains of a human being. The outline of the body was apparent, as well as a portion of the skull, ethmoid, and metacarpal bones; all the rest was converted into the wax-like substance which is called adipocere. The next day the 
bones of a horse were discovered only a few yards away from the spot where the human remains had been buried. The horse's bones were in good preservation, and no lime had been placed on them. The spot where these skeletons were found was situated outside the hedge of what had formerly been a lone cottage, not far from the high road; no record of any kind was found with them, nor are there any local traditions as to how this man and horse came to be buried in this out-of-the-way place. May it not be fairly imagined that some foul deed had taken place here in former times-some poor lost traveller entrapped into the house and murderedhis horse shot, and both buried-the man without a coffin, in lime, in order to get rid of the body quickly, the horse without lime, as its bones would not cause suspicion if discovered?

Upon inquiry I learned that several stories of highwaymen's deeds on Aldershot and Bagshot heaths are still recollected by the inhabitants of the neighbourhood. There is a small wayside public-house at the village of Hale, between Aldershot camp and the town of Farnham, which is pointed out as the site of the escape of Dick Turpin through its back windows. The landlord of the "Cricketer's Arms," near Bagshot, told me that the lone public-house on the top of Bagshot Hill was formerly called the "Golden Farmer" (it is now the "Jolly Farmer"), and was presided over by a high- 
wayman, or else a fellow in league with the highwaymen. Just beyond the "Golden Farmer" is a lane called to this day Gibbet Lane, as a man formerly hung in chains at the point where it joins the road.* An ancient postboy died at Staines not many months ago, who remembered affrays with highwaymen, and who bore the marks on his crippled foot of a bullet shot at him by one of these worthies, whose genus is now, thank goodness, extinct.

I recollect my mother telling me that, when she was a little girl, travelling over this very heath-land in a post-chaise on her annual visit to London with her father, she used to wear a bonnet the lining of which was stuffed with bank-notes for fear of the highwaymen. It has been recommended by an authority, that when modern travellers are journeying in suspicious, out-of-the-way places on the Continent, \&c., they should sew up sovereigns in the buttons of their coats,

* Our ancestors were not orer particular about their medicines, for according to "Pomet's History of Drugs, 1712," you may see in the druggists' shops of London; skulls covered with moss, and scme that have only the moss growing on some parts. This moss is called Usnea, because of its near resemblance to the moss that grows upon oaks; it is found on the heads of men that have hung in gibbets, or the like. The English druggists generally bring these heads from Ireland, that country having been remarkable for them ever since the "Irish Massacre." This moss was used in the composition of the "sympathetick ointment," arailable in the cure of "falling sickness." 
and so carry them without suspicion. But, say I, this plan won't do, for where would the traveller be if somebody should walk off with his coat?**

Close observation of the peculiarities of human skeletons and skulls will often lead to important results. The following is a case in point, and I have the more pleasure in recording it as it is a good example of the acumen of my late dear Father in such matters, and a fine bit of medical jurisprudence on the part of his old friend Mr. Clift, then curator of the Hunterian Museum at the Royal College of Surgeons, and the father of Professor Owen's amiable and agreeable wife. The

* Mr. Galton, in his "Art of Travel," under the heading "Secreting Jewels," says, "Before going among a rich but semicivilised people, travellers sometimes buy a few small jewels, and shut them up into a little silver tube with rounded edges; then, making a gash in their skin, they bury it there, allowing the flesh to heal over it. They feel no inconrenience from its presence, any more than a once-wounded man does from a bullet lodged in his person, or from a plate of silver set beneath the scalp. The best place for burying it is on the left arm, at the spot chosen for vaccination. By this means, should a traveller be robbed of everything, he could still fall back on his jewels. I fear, however, that if his precious dépôt were suspected, any robbers into whose hands he might fall would fairly mince him to pieces in search of further treasures." That this barbarous practice was once in vogue, we learn from Josephus, who when describing "the great slaughters and sacriledge that were in Jerusalem," tells us "that the Jews who deserted from the besieged city were in the habit of swallowing gold coins. The camp followers of the Roman army killed these unfortunate men for the sake of the money they might contain." 
incident happened when I was three years old, so I know nothing about the details of the case. I give it from a printed paragraph I find among the Dean's notes. The story is as follows :-

"In January, 1829, a quantity of human bones were found near the race-course at Doncaster. These bones were supposed to be the remains of a Mr. Wood, who had disappeared some years before, and was never heard of again. An inquest was held at the time the discovery was made, which was adjourned to allow of time for making inquiries. The adjourned inquest was subsequently held, the bones having been previously sent to Professor Buckland at Oxford, with a request that he would give his opinion as to the length of time they might have been buried, and as to whether they were the bones of a male or female. The answer was singularly interesting. The Professor, not being willing to rely entirely on his own judgment, sent them to $\mathrm{Mr}$. Clift, curator at the College of Surgeons, who said, that in consequence of the pelvis being wanting, he could not say whether they were the bones of a man or woman. He observed, that from a slight distortion of the vertebræ of the neck, the person, when living, must have held the head on one side. He further remarked, that the canine teeth of the lower jaw must have projected considerably. These two gentlemen also agreed that the bones might possibly have been 
interred ten years; but it was far more probable that only six or seven years had elapsed since that event. These circumstances, taken together, confirm the belief that the bones are the remains of Mr. Wood, who did carry his head a little on one side-his teeth projected in the manner described - and he has been missing about seven years. How or by what means his death was occasioned is not yet ascertained." - Sheffeld Courant.

Relative to the discovery of skulls, my friend Mr. Bush tells me a capital story. When in practice as a medical man at Witney, in Oxfordshire, he, one day, as he was going his morning's round, met the coroner on his road to hold an inquest. The coroner told him that the head and bones of a child had been found at - village, and that a woman was suspected of having committed a murder and concealed the body of her infant. A sudden thought struck Mr. Bush that he would like to accompany the coroner and attend the inquest, and fortunate it was for the poor woman that he did so. On his arrival at the cottage, the head and bones were brought out with due form and solemnity, while a crowd of gaping villagers stood chattering at the door. At first sight of the bones, Mr. Bush said, "Well, it's all clear about these bones, anyhow; they are rabbit's bones; there are the leg-bones, and there are the bladebones, \&c. They are no human bones at all ; 
but as for the child's head, I don't know what to say about that." An old woman then volunteered as evidence that Mr.— had been there and examined it, and given it as his opinion that it was a child's head or summut.* The shape of it was amazingly like an infant's head; yet the smell was very familiar to Mr. Bush ; only he could not call to mind at the moment of what common substance the smell reminded him. "Here," said he, "lend me a knife." So they brought a knife, and Mr Bush cut the child's head right in half. The knife went through it easily enough, and when the two halves fell apart the child's head turned out to be-what do you think?-why, soap! Nothing but a great lump of common yellow scap. The coroner stared at the villagers, and was thankful he had not officially sworn in the jury. The village sensation "caved in," as the Yankees say, but the poor woman's character was saved. A striking example how easily a person's good name may be injured. Now for the history.

It appears that the " child's head, or summut," had been found in a little flue, above a fireplace, in a cottage once occupied by an old woman. This old woman had been in the habit of keeping her bars of yellow soap on a ledge up the chimney; and one day she, by accident, had pushed a bar of soap down the flue.

* Oxfordshire for "something." 
It had in time become melted, and had, by some strange coincidence, assumed the form of a child's head, and thus caused all the fuss that was made about it.

My father, in his lectures, used to tell us a story, that in the neighbourhood of Oxford, some men who were digging earth found what they reported to be a giant's bones. The discovery made a sensation at the time; and to quiet the agitation, a coroner's inquest was held in due form over the skeleton, ending in a verdict honestly arrived at by twelve true and lawful Berkshiremen. Upon subsequent examination by competent authorities, the skeleton was pronounced, most decidedly, to be that of a Roman, who had been buried, with all his arms and military accoutrements, near the camp to which he had probably belonged, and of which the remains are still to be seen on the two hills called the Dorchester Clumps. Little did his noble companions in arms think, when they buried their chieftain, with all due solemnity, under a banner bearing the wellknown letters S. P. Q. R., that some hundreds of years afterwards the bones of their commanding officer wou'd be dug up again, and "sat upon by a crowner's jury" in an English public-house.

Among the cave bones in the Dean's Museum at Oxford are some which formed part of the skeleton of a woman. This skeleton was found extended in the SER. III.-VOL. II. 
usual position of burial, in a cave in Glamorganshire. The bones were stained with a dark-red brickcoloured substance, known as ruddle. Close to that part of the thigh-bone where the pocket is usually worn were found several small sea-shore shells in a state of complete decay; and, mixed with these, numerous fragments of small ivory rods, and ivory rings; together with a rude instrument (resembling a short skewer) made of the metacarpal bone of a wolf, flattened to an edge at one end, and terminated at the other by the natural rounded condyle.

The charcoal and fragments of recent bone (apparently the remains of human food) render it probable that the cave in which this skeleton was found had been at some time or other inhabited by human beings; and the circumstance of an ancient British camp existing on the hill above it strengthens the supposition. The ivory rods and rings are certainly made from the tusks that lay in the same cave, and were probably used to fasten together the coarse garments of the ancient British soldiers, or to serve as armlets for the dandies. The shells might have been kept in the lady's pocket, or have been used, as they are even at this day, in Glamorganshire, for a simple species of game. The wolf's toe was probably reduced to its present form by the hands of this ancient dame, and used by her as a shawl pin or skewer. The custom of burying with 
their possessors the ornaments and chief utensils of the deceased, is well known to have existed among the ancients-the Britons included.

Several theories were started to account for the peculiar red colour of the bones. Among others it was suggested that this old woman was in the habit of selling ruddle to the British soldiers in the camp close by ; and that, whilst still pursuing her avocation, she died a peaceful death in her cave: there being no wood to make her a coffin, her considerate neighbours had placed her in her own ruddle sack, and thus buried her.

In lapse of time the sack and the flesh decayed; but not the bones, which absorbed the ruddle, and thus assumed the peculiar red colour.

A fuller account of these bones is given by the Dean in his "Reliquiæ Diluvianiæ,"-I here give the outline of the story.

One day, after the Dean had exhibited these very bones to his class at one of his lectures, and mentioned the ruddle theory as regards their colour, the late Philip Duncan, Esq., of New College, handed him up the following lines, putting the whole story into poetry :-

Have ye heard of the woman so long underground;

Hare ye heard of the woman that Buckland has found,

With her bones of empyreal hue?

Oh, fair ones of modern days, hang down your heads!

The antediluvians rouged wher dead,

Only granted in lifetime to you. 
The tale goes, that the Dean, when lionizing a distinguished foreigner over his museum, showed him these red bones, and gave him Mr. Duncan's verses to read. The Frenchman, taking the whole thing serinusly, shrugged his shoulders when he read the fifth line, and exclaimed, "Mais c'est extraordinaire, voilà la coquette encore." 


\section{RELICS OF OLD LONDON.}

IN September, 1863, I was requested by Mr. Wareham, dealer in curiosities, corner of St. Martin's Lane, Leicester Square, to examine some human bones which had been discovered in digging a foundation in St. Mary Axe, City. They consisted, I found, of a thighbone, two leg-bones, and a lower jaw. The leg-bones were discovered actually in situ in the ring of an ancient pair of irons or fetters, such as we see represented as placed on criminals in pictures of Jack Sheppard. The irons, of course, were much corroded with rust. The bones were those of a person who must have been a dwarf, and the thigh-bone had been fractured some time previous to death. The lower jaw was of a large size, but still it is possible that all the bones belonged to the same skeleton, as dwarfs often have large heads. How this poor prisoner became buried where the skeleton was found may, I think, be explained by a note in "The Field" from my friend H. J. B. Hancock, Esq.

"Having been requested by Mr. Buckland to examine the bones recently discovered at St. Mary Axe, and 
mentioned by him in No. 558 of 'The Field,' I did so, and found that the victim had been bow-legged, and, from the size of the jaw-bone, probably hydrocephalic and an idiot. On looking into histories of ancient London, I find that at or near to the place where these bones were discovered, there existed, in 1.268, a burial ground of the space of one acre, given by Sir Thomas Rowe, the then Lord Mayor, for the use of such parishes as might be without graveyards, and also for old Bethlehem (Bedlam) Hospital. It does not seem unlikely, then, that the bones in question belonged to an inmate of Old Bedlam, who, with the carelessness usually exhibited towards lunatics in those days, was buried without any one taking the trouble to knock off his gyves, which are still riveted.

\section{"Henry J. B. Hancock."}

These bones are in my collection, and underneath them I have placed an engraving of the old Bethlehem Hospital, which I bought for one penny at an old book-stall; the date of the actual view is 1670 ; it was torn, I understood, from a work (I know not the title) by Overton, published in 1721. The poor man who was buried in his fetters might have been confined in this very hospital. 


\section{DISCOVERY OF THE REMAINS OF JOHN HUNTER IN THE VAULTS OF ST. MARTIN'S-IN-THE-FIELDS.}

IN the month of January, 1859, when sitting in the mess-room of the 2nd Life Guards, at Windsor, looking over the advertisement sheet of the "Times," the following caught my attention :-

"St. Martin's-IN-the-Fields-Church Vaults and Catacombs-Order in Council-Notice. Any person or persons having the remains of relatives or friends deposited in any of the vaults under the church, or in any of the catacombs under the churchyard, situate at the north-east corner of Trafalgar Square, are hereby informed that they may, if they so desire, remove the same before the 1st day of February 1859; after which date, all coffins remaining in the said vaults or catacombs will be reinterred in the same place, and finally built and closed up in accordance with the said Order in Council, and cannot afterwards be inspected on any pretence whatever.

"Benjamin Latchford, Churchwardens of the said Charles H. Petter, $\}$ Parish. 
"All communications to be made in writing, addressed to us at the Vestry House, Adelaide Place, W.C." Why, surely John Hunter* is buried in this church,

* The reader may possibly not know who John Hunter was. The following, published with portrait of Hunter, in "Leisure Hour," No. 385, May 12, 1865, is my feeble attempt to give some idea of his character :-

The generation among whom John Hunter lived and worked has now almost passed away, and the question is not unfrequently asked, "Who was John Hunter, and what did he do?"

Health, to all of us, is the greatest blessing that can be enjoyed in this life; and, during the inroads of disease, medical assistance is most valued. As individuals, we never appreciate a public benefactor so much, as when in person we receive direct benefit from his labours and discoreries. Without slighting the labours of other great surgeons and anatomists, it may be confidently affirmed that there is not a man, woman, or child among us who, when struck by the sting of disease, and receiving relief from the art of medicine, does not directly or indirectly receive relief to his suffering from the discoveries of John Hunter.

It seems to be an ordinance of Providence to raise up every now and then great minds among the human race, to whom it is granted to lift the veil of obscurity which envelops the great laws which regulate this universe, and to penetrate further than is granted to ordinary mortals into the mysterious workings of the Creator. John Hunter was one of these great "high priests of Nature;" the gifted explorer and interpreter of the laws of animal life, as affected by health and by sickness; the great master who had the ability and the will, not only to record his discoveries, but to forge from them weapons of defence, where. with those who follow him might wage fierce combat with that dread destroyer of mankind, the Dragon disease.

Pcreeiving that all created things are but a graduated chain 
was the thought that immediately struck my mind: his remains ought certainly to be looked after; but who

of animal machines, he was the first to trace the connections between link and link, from man down to creatures even lower than the sponge. Not only did he ransack the whole animal creation, but he submitted the regetable kingdom to his ordeal of inquiry, and forced it to yield up illustrations of health, growth, and decay. Instead of indulging in vain metaphysical speculations as to the ultimate causes of things, by dint of almost superhuman labour, both of mind and body, he compelled. Nature to answer for herself; and, perceiving the importance of these answers, he recorded them in the indelible type as cast by Nature herself in the infinite varieties of structures and tissues both normal and abnormal. He has thus formed a series of chapters of the history of animate beings, each chapter complete in itself, which, when read as a whole, forms a volume more than introductory to the comprehension of the ultimate laws of an overruling Providence.

Happily for posterity, he has left behind him these valuable records, in what is most properly called the "Hunterian Museum." On the south side of Lincoln's Inn Fields is situated the Royal College of Surgeons, one of the finest buildings in London, and honoured as being the repository of this museum, priceless in value, and matchless as to the rare specimens composing it. Several years after the death of John Hunter, it was bought by the government for a sum hardly adequate to its value, and intrusted to the care of this learned body of men, eminent in science and in professional knowlecige. Fully appreciating its national value, the college has not only religiously looked after and preserved its integrity, but has added very considerably to it. When they first came into the possession of the Museum, it consisted of 13,682 preparations, whereas no less than 31,019 are now displayed in its cabinets and on its shelves. There are sereral preparations of delicate structures, which are more than a hundred years old, now in the Museum. 
is to do it? I will try to rescue his remains. If I fail there will be no harm done.

My leave of absence from my regimental duties happening to occur most opportunely just at this time, I hastened to London, and the next morning found me under the portico of St. Martin's Church inquiring for the sexton. Upon asking him if anything was known of John Hunter, who was buried in the vaults of the church, I was not surprised to find that none of the officials of the place had ever heard of him, or knew anything about the matter. I knew not whence or how I had obtained the idea that John Hunter was buried-in St. Martin's vaults, but I fancied that I had learned this from my late lamented excellent friend Professor Quekett, then alive and well, so I went off at once to the College of Surgeons, to consult him upon the matter. The Professor informed me that he was not at all certain of the fact, but imagined that it was so. We at once consulted "Palmer's Life of Hunter," where we found the following passage:-

"Hunter's body was interred in a private manner, in the Church of St. Martin-in-the-Fields, accompanied only by a few of his medical friends."

This at once put me on the right course, and I went back again directly to consult the Register of Burials at St. Martin's Church. After some little trouble, I was delighted to find in the sexton's old register-book 
the following entry, written in a crabbed and careless hand:

"Leister Squar. Oct. 22, 1793.

M. "John Hunter, Esq., $\frac{1}{4}$ past 4 o'clock. $6 l .10 s .2 d$.

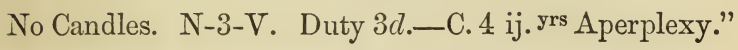

A few entries further down I found the entry repeated, but in a different formula, and a pen-mark through the entry as though it ought to have been entirely erased.

There were three things that puzzled me in these entries. The first was, how it could possibly happen that there could be two John Hunters. I had looked for one John Hunter, and had found two. I subsequently discovered a third. The second puzzle was the meaning of the letters " $\mathrm{N}-3-\mathrm{V}$;" and the third, what was the meaning of the letter $\mathrm{C}$ ?

After considerable inquiry I obtained the following solution to the enigma. The letters and figure meant "Vault No. 3." The letter C. meant certificate, and the letter M. male. The name had been entered -accidentally I suppose-twice in the registry.

At the time John Hunter died there were no coroners or coroners' inquests, * and certain persons were appointed in each parish-I believe generally old women - to examine the body of every person who died, and give a certificate that the deceased came by his death * See Appendix. 
from natural causes, and not from violence, and these people were called searchers. The letter C., therefore, meant that the certificate had been given in due course by the searchers.

I then sought the aid of Mr. R. K. Burstall, the vestry surveyor of St. Martin's, who, throughout all my labours in these dismal vaults, showed me the utmost attention, and afforded me the greatest assistance and facility in forwarding my search.* I understood from him that the men employed by the parish were to commence the work of removing the coffins to a distant part of the vaults. As I was, however, most anxious to find John Hunter's coffin before the Hunterian oration of that year was delivered by the Hunterian orator at the College of Surgeons, Mr. Burstall very kindly set the men to work immediately at No. 3 vault.

On going down below the church, we found ourselves in the crypt. This crypt is supported by massive pillars, and the spaces between some of them are bricked up so as to form vaults, some large and some small. There are the rector's vault-the portico vault-and the steeple vault, as well as several smaller vaults taken

* Mr. Burstall and myself worked admirably together in this really formidable business of moving the coffins. He tells me (Nov. 1865) that, on looking back to the task he had undertaken, he is certain he never could have gone through it without my encouragement and co-operation; and I say the same thing of Mr. Burstall. 
by private families. The larger vaults were guarded by strong iron gates, through which the coffins could be seen from the outside. For some account of remarkable facts that came under my notice in these vaults, I would refer to the Appendix. Mr. Burstall having unlocked the ponderous oak door of vault No. 3, we threw the light of our bull's-eye lanterns into the vault, and then I beheld a sight I shall never forget. After our eyes had got accustomed to the light, we perceived that this vault was a good-sized room, as full as ever it could hold with coffins, piled one over the other from the very top to the very bottom. Many coffins were even piled up crossways in front of the door, so that no entry could be obtained except by moving them, and others were jammed up together in all possible positions, without the least attempt at order, reminding one much of books packed in a box to be sent away. To the left of this vault there began another, in which there was a great mass of simple wooden coffins of persons buried anterior to the Act which ordered that no person should be buried except in lead. The faint and sickly effluvia which emanated from these vaults were truly overpowering and poisonous. I did not feel the effects of this till my work was over, and the excitement passed off. I was then exceedingly unwell for more than a fortnight, and from the peculiar symptoms was frightened about myself; but, thanks to a kind Provi- 
dence, I quite recovered my usual health after a time. Mr. Burstall tells me that he also suffered, and that he was obliged, soon after he had finished his work, to leave London for four months.

John Hunter's coffin was, I knew, somewhere among this mass of coffins in No. 3 vault. It was my selfimposed task to find it, and the only way I could do this was to inspect each coffin as it was brought out on its way to the catacombs outside the church. I therefore stationed myself at the door of the vault, and examined, by the light of a bull's-eye lamp hung on to the door-post, every coffin as it came sliding down the plank, occasionally climbing on to the top of themdangerous work by the way-and looking about among them with my policeman's lamp to see if I could find the much-wished-for name of John Hunter inscribed on any of the brass coffin-plates.

We worked away at this vault No. 3 for eight days, when Mr. Burstall decided to leave off for the present, and set the men to move the coffins at another part of the vault.

Fearing lest John Hunter's coffin might by chance have been removed from vault No. 3 to another part of the crypt, at some date between 1793 and 1859, I attended the men during the progress of this work in the further part of the church. I was glad I did so, as I discovered the body of another John 
Hunter, but the plate did not agree with the date of the John Hunter I was in search of. I also found the coffin of a Mrs. John Hunter, who died in 1820, but I do not know whether she was any relation to the illustrious anatomist and physiologist.*

* I am now in a position to explain all this, having been kindly favoured with the folluwing note:-

16 Hart Street, Bloomsbury Square.

September 8, 1866.

Sir,-I well recollect the time and circumstance of search being made in the vaults under St. Martin's Church for the coffin of John Hunter, the great surgeon of the last century, as reported in the daily papers of that period, who died October 16,1793 , and I also recollect it was then said that the remains of another John Hunter were found during the search.

Reading to-day your article in the "Leisure Hour" for September 1860, No. 177, I find the following paragraph :-

"Fearing lest John Hunter's coffin might by chance have been removed from vault No. 3 to another part of the crypt, I attended the men during the progress of this work in the further part of the church. I was glad I did so, as I discovered the body of another John Hunter, but the plate did not agree with the date of the John Hunter I was in search of. I also found the coffin of a Mrs. John Hunter, who died in 1820, but I do not know whether she was any relation to the illustrious anatomist and physiologist."

Now, Sir, will you permit me to enlighten you as to who the other John Hunter was, and also as to the Mrs. John Hunter you mention.

John Hunter died at No. 34 Brunswick Square, on February 6, 1812, at the age of 84 or thereabouts, and Catherine Hunter, his widow (the Mrs. John Hunter you name), died in March 1820, at an advanced age. They were both buried in what was then termed Doctor Hamilton's vault, in the Parish Church of St. Martin's- 
On February 14 we resumed our work at vault No. 3 , and as the pile of coffins became more and more diminished in number, I became more and more nervous, lest, after all, I should be on the wrong track.

My fears also were greatly increased by my being told that John Hunter was buried in St. James's Church, Piccadilly.

I had intended to search the register of this church, but I found the coffin of John Hunter a few days afterwards, so that I am ignorant who this other John Hunter was. It is just possible that William Hunter, John's brother, is buried in St. James's. I have not had time to look to this.

We worked on in No. 3 vault for seven days more, and, as the coffins decreased in number in the vault, I got very nervous, especially as I found the engraved brass name plates loosened from the tops of the older coffins, and was fearful that John Hunter's coffin-plate might also have got loose.

I was, however, encouraged by one of t]je labourers declaring that he had seen this very coffin in 1832, and in-the-Fields. John Hunter was at the head of the Nary Pay Office, Somerset House, London, having then recently received his superannuation after fifty years' service.

The above John Hunter and Catherine Hunter were my paternal grandparents.

$$
\text { I am, Sir, your obedient servant, }
$$

William Hunter.

Frank Buckland, Esq. 
that he recollected it, because "John Hunter invented vaccination."

After a time all the coffins were removed away from the vault but five; two lay side by side upon the floor, and three one over the other in a corner of the vault; and I could see the names on all these coffins except two: my chance was now therefore limited to these two coffins.

The total number of coffins in No. 3 vault was over two hundred. The total number of coffins removed was three thousand two hundred and sixty. This will give some idea of the task that I had undertaken and had now nearly finished. If one of these coffins therefore was not John Hunter's, all our labours would have been in vain. The workmen stood at the head and foot of the uppermost coffin of the three, and slowly moved it away that I might see the name upon that immediately below it. As it moved slowly off, I discerned first the letter $\mathrm{J}$, then the $\mathrm{O}$, and at last the whole word John. My anxiety was now at its height, and quickly running to one end, Mr. Burstall at the other, we moved the coffin away. At last I got it completely off, and to my intense delight read upon the brass plate the following inscription :-

$$
\begin{gathered}
\text { J O HN HUNTER, } \\
\text { EsQ., } \\
\text { DIED 16TH Octr., } \\
1793, \\
\text { AGEd } 64 \text { YeARs. }
\end{gathered}
$$


The Hunters' arms, viz., a hand with an arrow on it, also the three horns of the hunter, were upon the plate.*

Lest there should be any subsequent doubt upon the identity of this coffin, a photograph was taken of it by Mr. Soame, $\uparrow$ which I have presented to the Royal College of Surgeons.

The coffin, with its contents, immediately after I discovered it, were carefully removed to an empty vault under the church, where they were locked up by Mr. Burstall, who kept the key in his possession. The lead coffin was burst from the decomposition of the body within, and the upper lid was loosened; this lid was taken by myself a few paces from the coffin in order to be placed in a light favourable for the photographer. The cloth covering the coffin was in good order, and the brass nails upon it still bore their polish ; the bottom alone was injured by damp from contact with the ground. The brass plate was as good as the first day it was put on.

I hes e publicly beg to state that the sacred remains

* The vicar of the church happened, just before we found John Hunter, to have risited us. He had just left us when we found the object of our search. Hearing our shouts of joy (which we could not restrain), he kindly came back again, and congratulated us on our perseverance being thus rewarded.

t Copies of this can, I believe, be obtained from Mr. Hogartll, printseller, Haymarket. 
of our illustrious founder were in no way meddled with or disturbed, by any person whatever. I feel it my duty to place this on record, with my own hand and on my sole responsibility, and if needed Mr. Burstall will verify the statement.

Immediately after I had seen John Hunter's coffin placed in security under lock and key, I rushed off to the College of Surgeons, and communicated the intelligence to the President and Council and to Professor Quekett. The Professor and many members of the Council, as well as of our profession in general, during the next few days visited the vaults to examine the coffin, but none of them ever looked into it; - this I am certain of.

Though I had worked hard to gain the object I desired, I was not sorry that I had taken the entire responsibility, as well as the carrying out of the task, upon myself; for from my discovery arose two important events, viz. :-

1. The reinterment of John Hunter in Westminster Abbey.

2. And the erection of a marble statue to his memory in the Museum at the College of Surgeons.

There was some little difficulty about the reinterment of John Hunter's remains in the Abbey, but the matter was so warmly taken up by the authorities of the Council, and the Profession in general, especially 
by J. South, Esq., one of the Council, and Secretary of the John Hunter Statue Fund, that at last matters were arranged satisfactorily.

I recollected that when my father was Dean there had been some talk of placing a bust of Hunter in the Abbey. The Dean was so anxious that this should be done, that he had promised to use his influence with the Chapter to obtain some modification, if not the entire remission, of the usual fees. The bust had, however, never been placed in the Abbey. I therefore called upon several members of the Chapter, and told them this, in the hope of inducing them to take a favourable view of the propositions of the Council of the Royal College of Surgeons. After a time permission was granted, and the reinterment of John Hunter took place in Westminster Abbey on March 28, 1859.

\section{REINTERMENT OF JOHN HUNTER.}

The "Times" of March 29, 1859, begins the report by giving a short account of the circumstances of John Hunter's death in the board room of St. George's Hospital.

"The body was, in October, 1793 , privately interred in the Church of St. Martir's-in-the-Fields, where it quietly reposed, till the recent Order in Council requiring the vaults to be closed up, gave Mr. Frank Buckland, 
a member of the College, an opportunity of searching for, and ultimately securing, the precious remains, which were found enclosed in what must originally have been a very handsome coffin, covered with fine black cloth, and thickly studded with gilt nails and ornaments. On it was a brass plate with the family arms encircled in a rich scroll, with the cypress entwined, and bearing the following inscription: 'John Hunter, Esq., died 16th October, 1793, aged 64 years.' Beneath this the authorities of the College had caused another plate to be attached, stating that 'These remains were removed from the church of St. Martin's-in-the-Fields by the Royal College of Surgeons of England, March 28th, 1859.' The coffin, which had been deposited in the Abbey on Saturday evening, was reinterred yesterday afternoon on the north side of the nave, between Wilkie and Ben Jonson (the skull of the latter was freely handed about).

"There was of course no portion of the service appointed for the dead read over the grave, although it was fully expected that Mr. Green, the learned President of the College, would have delivered one of those eloquent orations for which he is so distinguished. The following was the order of procession :-The remains in the original coffin, borne on a high bier, followed by the Dean of Westminster; Mr. William Hunter Baillie, a grand-nephew of Hunter-Lord Ducie, Dr. Clarke of 
Cambridge, as representing the trustees of the Hunterian Museum-Mr. Frank Buckland (eldest son of the late respected Dean of Westminster, to whom the profession is indebted for the discovery of the remains), Professor Owen, the late Hunterian Professor-Dr. Mayo and Mr. Green, the Presidents of the Royal Colleges of Physicians and Surgeons-the Council and Professors of the College of Surgeons-the Censors of the College of Physicians-the Master and Wardens of the Apothecaries' Company-Mr. Thomas Bell, F.R.S., President of the Linnæan Society-Mr. Skey, F.R.S., President of the Royal Medical and Chirurgical Society-Mr. Hilton, President of the London Medical Society-Dr. Baly and Mr. Stanley, of St. Bartholomew's Hospital_ Dr. Tyler Smith and Mr. Spencer Smith, of St. Mary's Hospital-Dr. Bennett and Mr. Solly, of St. Thomas's Hospital_Dr. Chowne and Mr. Hancock, of Charing Cross Hospital_Dr. Ogle and Mr. Tatum, of St. George's Hospital-Dr. Freer and Mr. Shand, of the Middlesex Hospital_Dr. Radcliffe and Mr. Holt, of the Westminster Hospital_Sir William Ferguson, of King's College-Mr. Gay, of the Great Northern IIospitaland many distinguished provincial surgeons.

"Arrived at the grave, the coffin was without further ceremony deposited in its final resting-place, where it was inspected by the crowded assembly, amounting to about 600 . The entire arrangements were under the 
direction of Mr. Burstall, of 15 Hanover Street, Long Acre, and gave the greatest satisfaction."

A very handsome ornamental brass now covers the remains of John Hunter, upon which is the following inscription :-

"O Lord, how manifold are Thy works." *

\section{Beneath \\ are deposited the remains of \\ JOHN HUNTER.}

Born at Long Calderwood, Lanarkshire, N.B., on the 13th of February, 1728.

Died in London on the 16th of October, 1793. His Remains were removed from the Church of St. Martin's-in-the-Fields to this Abbey on the 28th of March, 1859.

The Royal College of Surgeons of England hare placed this Tablet orer the grave of Hunter, to record their admiration of his genius, as a gifted interpreter of the Divine Power and Wisdom at work in the Laws of Orgauic Life, and their grateful reneration for his services to mankind as the Founder of Scientific Surgery.

"In wisdom hast Thou made them all."-Ps. civ. 24.†

As regards the erection of the statue to John Hunter, the following document was issued :-

* On heading of the brass.

$\dagger$ On foot of the brass. 
"Royal College of Surgeons of England, "16th March, 1859.

"SIR,

"I am directed to inform you, that at a meeting of Council, in committee, held on Saturday last, the 12 th instant,

"It was resolved-

"That this committee feel that the reinterment of the remains of John Hunter in Westminster Abbey affords a most fitting opportunity to the members of the medical profession and others of raising a public memorial of their high appreciation of the physiological and surgical labours of John Hunter, which have mainly tended to the advancement of the science of their profession, and to the high rank of British surgery.

"They therefore determine that a subscription shall be opened for the purpose of erecting a statue of

\section{" JOHN HUNTER.}

"Resolved-

"That the following gentlemen, in addition to the members of the Council, be invited to join this committee :-

"The Trustees of the Hunterian Collection. "The President and Censors of the Royal College of Physicians of London. 
"The Master of the Society of Apothecaries of London.

"The Regius Professor of Physic of Oxford.

"The Regius Professor of Physic of Cambridge.

"The Director-General of the Army and Ordnance

(Medical Department).

"The Director-General of the Navy (Medical Department).

"The President of the Royal Society.

"The President of the Linnæan Society.

"The President of the Zoological Society.

"The President of the Geological Society.

"The Very Reverend the Dean of $\mathrm{W}^{\top}$ estminster.

"W. H. Baillie, Esq.

"Richard Owen, Esq.

"Frank T. Buckland, Esq.

"I have, therefore, to request that you will do the Council the honour of accepting their nomination, and to inform you that the next meeting of the committee will take place at this College on Tuesday, the 29th instant, at four o'clock, at which they desire your attendance.

"I have the honour to be,

$$
\begin{aligned}
& \text { "Sir, } \\
& \text { "John F. South } \\
& \text { "(Hon. Sec.). }
\end{aligned}
$$

"F. Buckland, Esq." 
The result of this committee was, that under the able and energetic management of John F. South, Esq., Vice-President of the College, and Secretary to the Committee, a sum of $1172 \mathrm{l}$. $17 \mathrm{~s}$. $1 \mathrm{~d}$. was collected, and Mr. Weekes chosen to make the statue. This eminent sculptor has faithfully reproduced in marble the celebrated and well-known picture of Hunter by Sir Joshua Reynolds, now in the Council-room of the College. The likeness is most admirable, and the attitude of this great physiologist (restored, as it were, again to life, and seated in the midst of his museum) is indeed most admirable and striking - a beacon of encouragement to all young men who have chosen for their part in life the glorious profession of which John Hunter was such a brilliant leader and pioneer.

My labours completed, my exertions were rewarded by the receipt, on August 29th, 1859, of a silver medal from the Council of the Leeds School of Medicine, with the following resolution :-

30 Park Place, Leeds, August 29, 1859.

Sir,-At a meeting of the Council of the Leeds School of Medicine, held a few days ago, I had the pleasure to move the following resolution, which was carried unanimously :-

“That a Silver Medal be presented to Francis T. Buckland, Esq., as a mark of respect, from the Council of the Leeds School of Medicine, for his exertions in placing the remains of John Hunter in Westminster Abbey."

In accordance with that resolution, I have the gratification 
of sending you the medal enclosed, the receipt of which you will please to acknowledge at your leisure.

\section{I remain, Sir,}

Your obedient servant,

SAyuel Syith.

The medal is exceedingly handsome. On one side it bears a remarkably fine portrait of John Hunter, by Wyon, and on the other the words-" Francisco T. Buckland. In memoriam eximiæ pietatis erga reliquias viri illustrissimi Johannis Hunter, Schola Medicinæ Leodiensis, D.D. A.D. 1831 inst."

In December, 1864, I received thirteen volumes of handsomely-bound books, with the following letter:-

"Royal College of Surgeons of England,

"London, "19th day of December, 1864.

"Dear Sir,

"I have the pleasure of forwarding to you with this letter a copy of the catalogues of its Museum, presented to you by the Council of this College.

"In the first page of these volumes is inserted the resolution of the Council presenting these catalogues to you; and I take this opportunity of forwarding a copy of the resolution of the Council of the 10th of March, 1859, viz. :-

" 'Resolved- 
" "That the thanks of this Council be given to Mr. Buckland for his active and efficient services in identifying the body of John Hunter.'

"I am happy in being the medium of transmitting to you the gift of the Council.

"Believe me,

"Very faithfully yours,

"J. Hodgson,

"President.

"To Frank Buckland, Esq.,

"Albany Street, Regent's Park."

To this letter from our President I replied as follows :-

37 Albany Street, Regent's Park.

To the President and Council of the Royal College of Surgeons.

Mr. President and Gentlemen, -

Allow me to express to you the extreme gratification I feel for the high honour you have done me in presenting me with a copy of the catalogues of your Museum, together with a formal vote of thanks of the Council passed March 10, 1859.

It would be needless, in this place, to refer to the reasons why the Council have conferred on me the double honour; suffice it to say, that in rescuing the mortal remains of our great and illustrious founder, John Hunter, from the vaults of the church of St. Martin-in-the-Fields, Charing Cross, on the 22nd of February, 1859, and afterwards having the satisfaction of witnessing those remains deposited amid the mortal remains of a glorious band of the most distinguished worthies that have adorned our country,-amongst the monuments of kings and 
queens, poets and historians, philosophers and divines, statesmen and warriors in Westminster Abbey, ${ }^{*}$ I feel that a high privilege has fallen to my lot.

The name of John Hunter, renerated not solely within these walls, but by the medical profession in all parts of the cirilised world, has thus--after his mortal remains have been mouldering in the dust these sixty-six long years-again shone forth, an encouraging and propitious omen to his professional children; and by the life-like statue which has recently been erected in his Museum, our founder once more seems to live and move among us, and to preside over his Museum, which so many of the gentlemen I hare now the honour to address have amplified and enlarged to the benefit of science and the good of suffering humanity.

From my earliest childhood I was brought up by my late respected father, the Dean of Westminster, to regard the memory of John Hunter with a respect approaching almost to veneration. I rejoice, therefore, that this early tutelage first suggested and then encouraged me in carrying out the services which I have been enabled to render to the remains of one whose example and memory must erer be dear to the sons of Esculapius; and when we see that these services are practically and formally acknowledged by the Council of the Royal College of Surgeons, it is a culminatirg point in the life of him who has performed them which can fall to the lot of but few.

Gentlemen, once more, both individually and collectively, I tender you my most sincere and heartfelt thanks.

Frank Buckland.

Feb. 8, 1865.

This then is the history of the last honours paid by the present generation to the illustrious John Hunter, and I rejoice exceedingly that Providence allowed me to be the humble means of bringing them about.

* See Sermon by Dr. Buckland "On the reopening of Westminster Abbey." 


\section{THE SKULL OF BEN JONSON.}

IT will have probably been observed that in the "Times" report of the reinterment of John Hunter (see a few pages back) a statement was made, "the skull of Ben Jonson was freely handed about."

Again, in the "Times" of November 11, 1865, the following paragraph appeared:-

"The Skull of Ben Jonson.-In the course of a paper read this week by Dr. Kelburne King, president of the Hull Literary and Philosophical Society, before the members of that Society, on 'The Recent Visit of the British Association to Birmingham,' the Doctor, in speaking of a visit which he and Dr. Richardson, of London, had made to Shakespeare's birthplace, at Stratford-on-Avon, narrated the following curious incident:- He said that a blind gentleman, who thought no one but the guide was present, mentioned that a friend of his had a relic which would be a valuable addition to the Shakespearean Museum at that place,the skull of Ben Jonson. When this friend attended the funeral of Dr. — at Westminster Abbey, he 
perceived that the next grave, that of Ben Jonson, had been opened, and he could see the skeleton of the body in the coffin. He could not resist the opportunity of putting in his hand and extracting the skull, which he placed under his cloak and carried off. From a remark which the blind gentleman dropped, Dr. Richardson thought he could identify the offender, and he asked if the person's initials did not consist of certain letters. The blind gentleman was not a little startled at finding that his secret was out; he admitted the fact, but prayed that no advantage might be taken of the discovery. This was promised; but, as Dr. Richardson is an ardent admirer of the Avonian bard, he is determined that, without going to extremities, he will bring the necessary pressure to bear on the possessor of the skull, so that it shall be placed in a more worthy repository than the cabinet of an obscure individual." Times.

I think it, therefore, my duty to the public to record what $\mathrm{I}$ know of the matter in this place.

In the year 1849, Sir Robert Wilson, Knight, was interred in the Abbey, and the place chosen for the grave was close to a triangular stone, let into the pavement in the north aisle, on which these words were inscribed :-

\section{O RARE BEN JONSON.}

My father, who was then Dean, told me that Ben 
Jonson * had, at his own request, been buried, not in the usual position, but that the coffin had been placed upright in the earth, with the feet downwards.

I have forgotten the exact particulars the Dean then told me, but I have since been down to the Abbey, and find from "Mentor" (who has acted as guardian of Dean's Yard for very many years), that a local tradition exists that Ben Jonson asked the king (King Charles the First) to grant him a favour.

"What is it?" said the king.

"Give me," said Ben Jonson, "eighteen inches square of ground."

"Certainly," said the king; "but where will you have it?"

"In Westminster Abbey," replied Ben Jonson.

* "Jonson, Benjamin, was born at Westminster, in the year 1574 , and educated at Westminster School; while he was there his mother married a second husband, by trade a bricklayer, and when Jonson became of sufficient age to be employed, he worked at his father-in-law's business. Some gentleman who saw him working with his father took compassion on him, and he was sent by Camden to Sir Walter Raleigh. In the year 1598, his fame rose by the production of the comedy of ' Every Man in his Humour,' at the Globe Theatre, and from this time he adopted the practice of writing a play every year. He appears to have suffered much from poverty in the latter part of his life. He died on August 6, 1637, and was buried three days afterwards in Westminster Abbey." He was the friend and cotemporary of Shakespeare, "who, in 1598 , had been admitted to an intimacy with Ben Jonson." 
"Your request is granted," said the king.

Ben Jonson knew that if he had asked direct for what he really wanted he would probably have been refused; he therefore adopted the above ingenious plan of obtaining a favourable answer.

The above is (as I have said before) the local tradition. I should feel much obliged if any reader of this could tell me if it is recorded in any book; I myself have searched in vain.

When, therefore, Sir Robert Wilson was buried close to the triangular stone which marked the grave of Jonson, my father instructed me to go into the Abbey and look after the grave-diggers, in order to ascertain what I could about the above-mentioned tradition.

After a time, the men found a coffin very much decayed, which, from the appearance of the remains, must have originally been placed in the upright position. The skull found among these remains, Spice the gravedigger gave me as that of Ben Jonson, and I took it at once into the Dean's study. We examined it together, and then going into the Abbey, carefully returned it to the earth; retaining, however, a few fragments of the coffin wood.

John Hunter's grave, I observed, was ordered to be dug somewhere near the spot where we had deposited the skull some years before, so I gave minute instructions to the grave-digger (the same man, Spice, that

SER. III.-VOL. II. 
had found it before), that if he should by chance turn up Ben Jonson's skull again from the earth, he should take great care of it and give it into my charge. In the course of his work he did find this skull again, and when I went down early in the morning of the day of the reinterment of John Hunter, to examine the grave, the old man told me he had found Ben Jonson's skull. He gave it me, and I knew the skull again quite well.

A thought came across me, thus:-To-morrow there will be a crowd of folks here, and it is more than likely that, seeing the inscription on Ben Jonson's triangular head-stone, they will look out for, and possibly carry off, the poor man's skull, if they can find it; so I at once dug a hole in the earth which had been dug out of the grave, and piled up under the ledge of the monument of Colonel James Bringfield* close by; in this earth I hid Ben Jonson's skull safely away.

When the ceremony of the reinterment of John Hunter was completed, I went out with the rest of the people; but as soon as the Abbey was clear, and the men began to fill up the grave, I went back again by

* "Col. James Bringfield, equerry to Prince George of Denmark, aide-de-camp and gentleman of the horse to the great Duke of Marlborough. He was a native of Abingdon, in Berkshire, and was shot by a cannon-ball at the battle of Ramilies, on Whit Sunday, May 12, 1706, whilst remounting the Duke on a fresh horse, 'his former fayling him.' He was interred at Bavechem, in Brabant." 
a private door, and with my own hands placed Ben Jonson's skull on the top of John Hunter's coffin, and waited till the grave was nearly filled up, and there could be no possibility of removing the skull.

A few days after the above quoted statement appeared in the "Times," the Dean of Westminster, Dr. Stanley, sent for me to inquire if I knew anything of Ben Jonson's skull. I called upon him at once, and after I had stated to him the facts as above recorded, we went into the Abbey to look at the localities. Wishing to confirm my story, I inquired for Spice, the grave-digger, but found that he had been dead some time. "Mentor" told me that one Ovens was still alive, and that Ovens assisted Spice to dig the graves for both Sir R. Wilson and John Hunter. We therefore went down to see Ovens, whom I found so old that he could tell me nothing at all; in fact, the poor old man's memory was nearly gone. I then asked for Mr. Ryde, who was clerk of the works in my father's time; and having ascertained that he had retired into private life, at once called upon him.

And now I have another story to tell about this matter. Mr. Ryde informed me candidly, and at once, that he was quite certain that $I$ had never had the right skull at all, but that he took charge of it.

When Sir Robert Wilson was buried, in 1849, he (Ryde), in his official capacity, superintended Spice and 
the other grave-digger in their operations. The earth in which the grave was made was loose sand; this sand he expected had been carted into the Abbey, as it was above the natural soil of the place. As the grave was being dug, this loose sand "rippled in like a quicksand;" and in the course of the operations, Ryde himself saw the two leg-bones of Jonson, fixed bolt upright in the sand, as though the body had been buried in the upright position, and the skull came rolling down among the sand, from a position above the legbones, to the bottom of the newly-made grave. Ryde picked up the skull and carried it to the clerk of the works' office, in the cloisters, and there he locked it up till the newly-made grave was nearly filled up; he then brought it back again into the Abbey, and buried it about twelve or fifteen inches under the triangular stone on which the words "O Rare Ben Jonson" are inscribed. He remarked that there was hair still on the skull, and it was of a red colour.

In 1859, when the grave was made for John Hunter, Ryde was still clerk of the works, and John Hunter was to be buried close by the side of the grave of Sir Robert Wilson. It was likely that Ben Jonson's skull would again be found. Ryde therefore kept a look out for, and found the skull under the triangular stone where he had placed it. The skull had still traces of red hair upon it. Again, for the second time, 
he took charge of it, and when Hunter's funeral was over, he again buried it some twelve or eighteen inches under the triangular stone, and here he says it is to be found at this moment, never, I trust, to be again disturbed. Three or four skulls (Ryde told me) were found in digging Hunter's grave, but they were at some distance to the westward of Rare Ben Jonson's stone. All three skulls he replaced again in the graves; but both he and Spice remarkec that one was missing.

This, then, was the skull in the possession of the blind gentleman's friend, as mentioned in the "Times" of Nov. 11. It must have been taken out of the Abbey at the time of Hunter's funeral.

Anyhow, it is quite positive and certain that the skull in question is not that of "Rare Ben Jonson;" for two persons distinctly state that they took charge of it, and returned it to the earth, viz., first, Mr. Ryde, the clerk of the works, and, secondly, myself.

I candidly confess that, in my opinion, the skull that the clerk of the works took under his charge on both occasions, as above stated, was really the skull of Ben Jonson, and this on account of the red hair which he observed upon it. Thanks to our excellent library of the Athenæum Club, I have been enabled to get curious particulars relative to the personal appearance of Ben Jonson. In a volume, entitled "Letters written by Eminent Persons, in the Seventeenth and Eighteenth 
Centuries, and Lives of Eminent Men. By John Aubrey, Esq. The whole now just published from the originals in the Bodleian Library and Ashmolean Museum. Longman, 1813"-I find evidence quite sufficient for any medical man to come to the conclusion that Ben Jonson's hair was in all probability of a red colour, though the fact is not stated in so many words.

Let us now therefore sum up the evidence.

The skull Ryde found had red hair upon it; it was probably therefore that of Ben Jonson's.

. It was found twice under the triangular stone on which the words "O Rare Ben Jonson "were inscribed.

It was twice taken thence, and protected against the chance of further removal.

It was, on the 28th of March 1859, buried eighteen inches below this triangular stone.

It has not been in any way disturbed since.

I think therefore the public may rest assured that the skull of Ben Jonson still lies beneath his gravestone in Westminster Abbey.

As regards the stone on which the words "O Rare Ben Jonson " are inscribed, I would beg to inform the reader that there are two stones which bear this inscription: one a triangular stone on the floor of the church, the other a square stone let into the wall a few yards to the north of the grave, underneath the monument of Colonel 
James Bringfield. As regards this latter (the older) stone, Ryde told me that he found it in the stone-yard of the clerk of the works' office, in the cloisters, and reported it to my Father, who immediately examined it, and ordered a new place to be cut for it in the position where it can be now seen. Ryde and my Father together fitted the stone into the place which it now occupies; the Dean at the time remarking to Ryde that the name was spelt wrong, and not the correct way, "Jonson." There is, however, no doubt whatever that this square was the original stone which had been over the grave of Ben Jonson, the triangular stone being that which was put down when the floor of the Abbey was repaved, at the latter part of Dean Ireland's time.

There is a tradition connected with this original stone, and it is that Ben Jonson's friends intended to place a fine monument in the Abbey to his memory; this however was never done, and there would have been no record at all of the place of his interment, had not a friend of the poet's given a small fee to a mason that he found at work at another monument, soon after his funeral, to cut the two simple words we now read.

I have made it my business to find out the origin of this tradition, and am glad to have arrived at the facts of the case. Aubrey records as follows.

"Mr. Benjamin Jonson, Poet Laureat (I have heard 
my uncle Danvers say, who knew him), used to live without Temple Bar, at a combe maker's shop about the Elephant and Castle. In his later time he lived in Westminster, in the house under which you passe as you goe out of the church yard into the old Palace, where he dyed. He lies buryed in the North aisle in the path of Square stone (the rest is lozenge) opposite to the scutcheon of Robertus de Ros, with this inscription only on him in a pavement stone, blew marble, about 14 inches square-

\section{O RARE BEN JONSON.}

$W^{\text {ch }}$ was donne at the chardge of Jack Young (afterwards knighted), who walking there when the grave was covering gave the fellow eighteen pence to cut it." 


\section{NATURAL HISTORY OF THE SALMON.}

\section{NOTES IN IRELAND.}

GALWAY AND CONNEMARA.

THE high privilege which we enjoy of travelling quickly and cheaply to the remote districts of the United Kingdom, cannot, I think, be too highly appreciated by all classes of society.

The universal exodus from this great metropolis (like the migrations of anadromous fishes) takes place every autumn, and thousands of gentlemen and ladies liberated from the labours of Parliament-the duties of the bar-the office,-the consulting-room-or the toils and duties of London society, spread themselves far and wide through her Majesty's dominions. Many are in search of what is ordinarily called pleasure, many go for sport alone. If these countless travellers would only take the trouble-I should rather say, afford themselves the pleasure-of observing and recording what they see around them, I am convinced that they might gather an immense amount of information, hitherto un- 
developed, which would be useful not only for themselves but the public in general.

Within the last few years a great change has come over the habits of the thinking British public. I would especially remark that natural history is now undergoing a new phase, viz., its conversion into practice. It was remarked by my friend Mr. Ffennell, late Inspector of Salmon Fisheries, ${ }^{*}$ at the lecture I had the honour of giving at the Society of Arts on fish culture, that, " during an official investigation in Ireland in which he was concerned, an important question in natural history arose. The parties interested were represented by counsel, by whom the most opposite scientific theories as to the habits and properties of fish were advanced. At length an adjournment of the investigation was agreed upon, in order that the questions raised in the course of the inquiry might be referred to certain members of the Natural History Society of - - It was, however, found that they were not able to give any information with regard to the habits of the sole, the salmon, or the turbot, which would assist the fishery commission in coming to a decision."

The field of observation, therefore, is immense, and we are but just entering upon the confines of this unexplored land. I would now, therefore, hoist the colours, and beat the drum for recruits in this good cause, and

* Mr. Ffennell died March 12, 1867, aged 67. 
say to every one, "Keep your eyes open, your intelligence sharpened ; facts, facts, facts are what we want;" for no one knows but that a fact, insignificant in itselfif it only be a fact-may lead to most important results, not only in the cultivation of land, but also in the hitherto much-neglected cultivation of that which composes two-thirds of the earth, viz., the waters, whether inland or oceanic. He, therefore, who will discover any new fact relative to the natural history of useful fishes, as the salmon, trout, sole, turbot, and that bivalved puzzle, the oyster, will be conferring great benefit upon the public at large.

First, then, I would recommend all travellers to supply themselves with maps on a pretty large scale (the two-shilling Ordnance sheets are the best) of the country they are about to visit, and I would recommend them, before starting on their journey, to read any description that can be obtained of the features and products that will probably be brought to their notice. In a country new to the traveller there must of necessity be always something that will repay observation. Thus, whether he is in quest of sport or not, he should observe the geological formation, and the animal, vegetable, or mineral products of the country, together with the effect of the combination of various physical circumstances upon the habits and personal appearance of the population that cultivate the soil. 
Great interest may also be afforded, particularly to the angler, by tracing out the various water-sheds which go to form the "catchment basins" of the rivers in which he is about to fish. By taking an Ordnance map of the district, and running a blue or green line-never spare a map, write upon it freely-around the sources of the springs at the hill tops which supply the main river, and also marking out the river and its windings in bright red, it will at once be perceived whence the water is obtained, and what qualities are given it by the geological formations through which it flows, and the kinds of fish which in consequence are found therein.

Thus, for example, he will learn that the requisites of a salmon-fishery are three.

First, the sea, without which the salmon cannot acquire its full development; 2nd, a river of more or less length-sometimes the river flowing from a lakeup which the fish run from the sea; 3rd, numerous streamlets flowing from the elevated regions and mountain districts, into the river and into the lake. It is an invariable rule that the more small tributaries there are to any salmon-fishery, the more salmon, if properly protected, there will be in it, and in proportion to the area of breeding ground so will be the number of salmon captured in the fishery. The question, therefore, of geological elevation and depression becomes of great 
INSTEAD OF KILLING ANIMALS WATCH THEM. 253

importance in the development of a salmon-fishery. It is far more important than actual extent.

Again the composition of the water must be observed.

Salmon in considerable quantities run from Galway Bay up into Lough Corrib, but few white trout are caught with them.

In other districts of Ireland, on the contrary, large numbers of the white trout are caught in company with the salmon.

The reason of this-and I have it on the authority of Mr. Ffennell himself-is, the existence of bog water in the rivers. Those who have fished the streams and lakes about Ballinahinch know well that they contain abundance of white trout. The reason is that (from some unknown cause) white trout prefer streams which contain bog water to those which do not contain it. On the east side of Lough Corrib no white trout are found-there is but very little bog water: but they are found on the west side, where the feeders of the lake run through a country abounding with bogs.

Many gentlemen, I would venture to remark, start on their travels armed with rod or gun, for the sole purpose of killing or destroying, whether by land or by water; to these I would say, do not care so much for the actual killing the animal or fish, as for the investigation of its habits and the conditions of its existence. The actual habits of the living creature are quite as 
worthy of attentive observation as the transitory pleasure of merely turning it into an object of sport.

I will now endeavour to give some slight idea of what I saw and learnt during a journey over a country new to me, and trust my readers will forgive all imperfections and shortcomings.

We came into Galway at dusk, tired, hungry, and dust-covered, but greatly pleased at a prospect of a little hard work out of doors. Early bird fashion, I was up pretty soon, to have a look about and a comfortable bath. I walked up from the fishery house to the weir, and just above the bridge perceived a number of dark-looking objects lying motionless in the glass-clear, ever-flowing water. The morning sun was shining bright, and I was fearful my shadow would fall on the objects, whatever they might be, so I dropped instantly on my hand and knee, and bending forward, peeped over at them, feeling a sensation, I should imagine, similar to that experienced by a pointer dog when making a discovery of a covey of partridges on the 1st of September.

Can those dark-looking bodies, then, be salmon? Oh! you shining, lovely creatures! At last, then, I see you free and at liberty in your native element. Mysterious water fairies, whence come ye? Whither are ye going? Why do ye hide your lustrous and beautiful figures in the unseen and unknown caverns of 
the deep blue sea? Why do ye shun the eye of mortal man? Hitherto I have seen you only lifeless, mummied in ice, and lying in marble state on fishmongers' slabs. Who could believe that in life you are so wondrously beautiful, so mysterious, so incomprehensible? Thousands and hundreds of thousands of your babies have I reared up from the egg to fishhood. But now, there you are, full of life, health and activity, a herd of water-cattle, impelled by a marvellous oropyì to perform the functions that nature has allotted to you, and destined to multiply and to serve the behests of man, to whom has been delegated dominion not only over the beasts of the field, the fowls of the air, but also over the fishes of the sea.

Ah! what is that? a silver flash in the water! See, yon huge fish, the master of the herd-the leader of the caravan through the watery deeps-has seen the movement of my uplifted arm. Like an arrow from a bow he shoots forward a yard or two, and then drops back slowly and gracefully down into his place. See, again, a game of play between two of the younger and more lighthearted salmon grilse. No swallow round the steep!e-tower, no seagull in a wind, ever sailed so gracefully or so swiftly as you; surely ye are wondrous creatures; I admire, ah ! I love ye.

But why remain here in the shallow water, my pretties? Why not get up into the deep still waters 
of Lough Corrib at once, where you would be out of harm's way in the deep caverns of the vast lake? Let us see if the road is clear for you. So I walked along a while, and soon came to the celebrated Galway weir. The water was so low, that it was only just dripping over the edge of the weir, but at the west end of it was the salmon-ladder so wisely erected for the benefit of the travelling salmon.

I had watched my trained minnows oftentimes going up the model salmon-ladder erected by Mr. Ffennell, jun., close to my fish-hatching-boxes at the Horticultural Gardens; but in a moment I saw what a useful invention the salmon-ladder may be; how the success or failure of a fishery may depend upon this ingenious mechanism, if it be only fixed in the right place. We have a hen-house admirably adapted for the farmyard poultry, but it is too high for the birds to fly up and deposit their eggs, which they are willing to do for our use and benefit. Surely let us place a ladder for them to go up into their roost. So, too, with the salmon. Thousands and thousands of miles of water are now running deserted and salmonless in upland streams in England; and why? because the fish are prevented and excluded from running up the rivers by weirs, mills and other obstructions which the hand of man has placed across their pathway. It is highly impolitic not to make an efficient pass over these. Nay, more : it is 
not only foolish, but positively cruel to these noble salmon-whom we thus treat as our worst enemies, instead of, as they really are, our best friends ; and as vermin rather than as valuable additions to our tables. What would happen, may I ask, were we to stop out breeding foxes from their earths in woodlands, or to cut away all the covert where pheasants love to make their nests? We know from experience, unhappily, what happens if we bar the fish out of their breeding places.*

* One of the chief reasons why the fisheries of the Thames have been falling off, is I believe the construction of the narigation weirs, which are terrible obstructions to the ascent of the fish. In the spring thousands of coarse fish, valuable for angling purposes, and as food for the poorer classes, assemble at the weirs. For the last three years the weirs have been opened and the fish allowed to ascend; mainly through the energy of my friend Stephen Ponder, Esq., one of the most active members of the Thames Angling Preservation Society, and with the permission of the Board of Thames Conservancy. At the representation, moreover, of the Thames Angling Society, this Board have most liberally built two fish-ladders, one at Moulsey (Hampton Court) weir, the other at Teddington weir. We still persevere in our attempts to stock the river with salmon, and for the last three years hare turned out above one hundred thousand young fish, both salmon and trout. We are laughed at for our pains, but the laugh will be on the other side when the salmon are restored to the Thames, which I sineerely trust will take place at no distant period. Anyhow, it shall not be our fault if this wished-for event does not take place.

The public are invited to examine our hatching process carried on during the winter months at my friend's, Stephen Ponder, Esq., at Hampton; and our rearing-ponds (also liberally provided 
The Galway salmon-ladder is a good specimen of its kind; it is constructed of solid slabs of stone placed in such a position that the water rushing down it comes in direct contact with the main current below, and that the salmon ascending shall find it without difficulty.

Letting myself down from the platform above on to the walls of the ladder, I observed that the water from the lake came through the first "slot" or opening of the ladder in a solid glass-like mass; but that once in the steps of the ladder, it bubbled and boiled like a young Niagara.

Being in an experimental turn of mind, I bethought me I would for a moment just try and see what sort of sensation the salmon experienced when making headway through this cataract, and at the same time get a pleasant morning bath. Oh! that I had scales and fins for five minutes, thought I; never mind, I must do without them. I then stepped into the ladder-but as quickly scrambled out again, for the rush of water tripped up my feet in an instant from the slippery floor of the ladder. I must look out, thought I, or I shall just go down the ladder like a $\log$ of wood over a Canadian portage and not up it salmon-fashion, and, if somebody does not throw a salmon-fly neatly over me and

by the Thames Conservancy Board), close to the lock at Sunbury. The young fish are here preserved from their enemies till large enough to be set free in the river itself. 
play me judiciously with the rod, or if 'Turk, the ganger of the salmon-nets at Renmore Point, does not catch me in one of his hauls, by Jove, I shall go out to sea, and barnacles and oyster spat will adhere to me; or I may have to take up my quarters-I should not mind it for a while-with the seals at the back of the Isle of Arran, till I am caught and exhibited as a talking, writing, and performing fish. Not liking to be beaten I chanced. all this, and again made a cautious descent into the ladder, and, placing my feet against the step below me, imagined myself to be a salmon, congratulated myself on narrow escapes from the nets and the cruives below, and bethought me how desirable it would be to get up to winter quarters in Lough Corrib above. But all I could think or do, I could not advance one single inch up the ladder against the stream. If I moved, in an instant the water knocked me about against the stops like a wood-chip in a street gutter after a thunderstorm. So I chose a corner of the ladder where the water boiled and bubbled round, and sat there, wishing and trusting that some salmon would take it into his head to ascend while I was in the ladder. We should hobnob very well together, thought I, and we would smoke the pipe of peace together. Presently I heard a voice behind me-

"Bedad! yer honner, you're the finest fish I ever see in the ladder this long time; and, by the powers, if I 
had got a gaff in my hand, I'd just strike it into your scales, and see how you would like it.'

I looked up, and there was one of the water-bailiffs, who, watching me from afar off, could not imagine what huge sea monster had got into the ladder and was floundering about in it.

We had a good laugh over this at the breakfast-table; and our host made a note that at the next session of Parliament, he must ask for a special clause to be inserted to prohibit Mr. Buckland, and other semi-amphibious Cockneys, from floundering about in salmonladders at unreasonably early hours on sultry summer mornings. 


\section{THE SALMON NETS.}

You see the ways the fisherman doth take

To catch the fish; what engines doth he make.

Behold! how he engageth all his wits,

Also his snares, lines, angles, hooks, and nets.

Bunyan's Pilgrim's Progress.

THE fishery at Galway is founded upon charters and rights of great antiquity, and the visitor cannot but be struck with the inscription over the door of $\mathrm{Mr}$. John Miller's* house :- " Galviæ Insula, unde civitatis nomen. Jus ad capiendas pisces reservatum Hen. iij., A.D. 1121." $\dagger$ The river which connects Lough Corrib with the sea is but of a short extent, and runs along the outskirts of the town. Through it the salmon must pass on their way from the sea to the lake above, and the salmon when en route pay tithe and tribute to their lawful owners, as in former time the barons living in the old castles on the Rhine exacted black-mail from the travellers on the river below. There are three

* Mr. Miller is lessee of this fishery, under my friend T. Ashworth, Esq.

+ "The island of Galway, whence the name of the township. The right to capture fish in the reign of King Henry the Third A.D. 1221." 
stations where the nets are worked; the principal one is Renmore Point, a mass of rocks which juts out into the sea, and forms one side of the harbour mouth, while the pier-head forms the other. This is the place where the salmon congregate before they leave the sea for their journey up the river, and is therefore a good place to catch them.

As we came on to the quay, I imagined that the men working at the nets in the distance had gone suddenly mad, for they were all hammering (like people killing rats in a barn) at some white shining bodies which were kicking about among the rocks.

"They are killing the salmon," said Mr. John Miller, who joined us; " they have got a famous catch this morning, for the fish seem in a humour for running up."

"See yon," said I, " that grand fellow just springing clean out of the water, like a sperm whale at play. How he glitters, all enamelled with silver. Surely he is dancing the 'gillie callum' or sword dance. We will have you presently within the net, my boy, unless you look sharp and swim up beyond its sweep. Look, there is another, and another, and another, all dancing, too. Surely an excursion train has just come in from the broad Atlantic, and these are the passengers set loose, and having a free-and-easy among themselves. I suppose it's the sea lice that's worrying you so, my lads. You 
cannot scratch them off with your fins, so you are just going to try to shake them off; but they have terrible hook-like claws, and you will have a difficulty to do it." I own I became terribly excited, and as eager to get a haul at the nets as Jim Hills, the huntsman of the Heythrop, is to get "forrard, hark forrard!" to his hounds when the old dog-fox breaks covert from Tar Wood the first hunting morning of the season. So we shouted like lunatics to the men, who immediately saw us, and pulled across to us.

"Ah !" said I, " I see; my little glass magician here tells me that the specific gravity of the water is 1.006 , and the temperature $63^{\circ}$, therefore it must be pretty nearly fresh water here, although we are nearly on the sea." These Galway salmon are caught in nets which are barely twelve feet in depth, while the water below them averages thirty feet deep. According to a theory of the owner of the fishery they prefer swimming in the fresh water, which runs over the salt water-like cream over milk; and, having had enough of sea-water for some months past, are glad to have a roll and a tumble in the fresh to which they have at last arrived.

"Your honour's welcome," said the men, as our boat grated her keel on the rocks. "Long life to your honour!"

* The sea-lice are not the primary canse of salmon learing the sea, as is held by some. 
"You must show me some sport, lads," said I, "for I have come all the way from London to see you."

"Bedad, Doctor !" (the men christened me "Doctor" at once) "we will."

Fine, sturdy, hardy fellows these fishermen-regular water-dogs, and as hard as nails, though the cold they have to endure is sometimes very great.

"Round with the nets, lads!" cried Miller. The coble boat (which Mr. Miller has introduced from Scotland) at once darted from the shore:

Finibus omnes,

Haud mora, prosiluere suis ; ferit æthera clamor Nauticus; adductis spumant freta versa lacertis. Infindunt pariter sulcos; totumque dehiscit, Convulsum remis rostrisque tridentibus, æquor.*

VIrgIt, Eneid, v. 139.

Round she went, describing a great circle, whilst the net played itself off from the board at the stern of the coble with a grace and ease that the engineer of the transAtlantic telegraph cable might well envy. Arriving again at the rocks, after they had performed the circuit, the men threw over from the head of the boat a heavy stone as an anchor, leaving her to take care of herself, and ran

* With shouts the sailors rend the starry skies; Lashed with their oars, the smoky billows rise, Sparkles the briny main, and the vexed ocean fries. Exact in time with equal strokes they row ; At once the brushing oars and brazen prow Dash up the sandy waves, and ope the depths below. 
up to a windlass which was fixed into a hole in the rock, and kept steady with big stones. The strain on the rope was tremendous as the tide swayed the long net away into a huge bag; but at length it approached the shore, and all was excitement.

"There are fish in the net," says Miller.

"How can you possibly tell ?" said I, "for the bag of the net is twenty yards off."

"If you look close to the top of the water," said Miller, "you will see two or three little air-bubbles, about as big as hazel-nuts, rising to the surface. Fish nearly always emit these bubbles when in the net, but the reason I do not know; and it requires a sharp eye to see them at all."

"There he is," said I; "a huge fellow has just swum in towards the shore, evidently aware that he is a prisoner. Look, he has gone back into the bag, but we shall soon handle him, I guess."

In a few minutes the bag of the net began to show at the top of the water, and the men ran quickly with it up the slope of the rocks. What a sight was there! some fifteen or twenty beautiful salmon, struggling and leaping, fighting and gasping for their dear lives.

The men at once began killing the poor fish, giving each of them a tap on the head with a short club, which they call the "killing-stick;" in some places, I believe, it is called "the priest." I also seized a killing-stick, 
and helped the men to put the poor creatures out of their misery; a very slight tap on the head is sufficient to stun and kill them. The blow given, the whole body of the fish quivers and vibrates for a second or two in the most remarkable manner, and I fancy sometimes becomes slightly iridescent. There is also a peculiar scent about a salmon just taken out of the water-a "game" odour by no means unpleasant-the cucumber scent of a smelt is not unlike it. The poor fish, of course, did not make the least resistance, more than dancing and fluttering about in the nets; but I thought that if they had the power and will to bite us, we men should have been obliged also to dance and flutter about to get out of their way, for they have pretty sharp teeth. We had hardly finished killing the fish of this haul, before another lot were landed. The gang of fishermen are divided into two parties, and there is always a net being either payed out of the boat or else being hauled in every minute during the time allowed by the tide for fishing. Two, three, four hauls consecutively may be blank, but the fifth haul may encircle a large number of fish; the reason of this is, I am convinced, that the fish come in from the sea in family parties, and swim steadily along, every now and then sounding a halt like a troop of cavalry. If the fish happen to stop in the space commanded by the net, they will of course be all captured; and as it is impossible to know the exact moment when 
the fish run up and halt, it is necessary to keep the nets perpetually going, hit or miss, on the chance of their being present. Sometimes the fish are seen some hundred yards out at sea below the net springing out of the water like flying-fish, but still advancing steadily towards the river. When this is seen, the nets are nearly sure to have a good take in a few minutes.

No human being knows for certain how far the salmon go out into the sea when they descend from the river. Mr. Miller tells me he has evidence that they go a long way out into the Bay of Galway. One morning, moreover, I had a long chat with the Cladagh* fishermen as they were sitting altogether smoking their pipes, and without my putting any kind of leading question these men all assured me that they had seen salmon in the Atlantic some twenty miles beyond the Isle of Arran, a most remarkable island. This island is some twenty-three miles from the mouth of the river, and upon it the huge Atlantic waves sometimes break with terrific violence. The men assured me that the salmon they had observed at sea were apparently on the march, invariably jumping out of the water with their hearls towards the Bay of Galway.

* These men inhabit a certain portion of the town of Galway, and are said to be the remains of an ancient Spanish colony. They keep themselves quite distinct from the inhabitants of Galway. Their history is most interesting. 
It is out at sea that these mysterious fish lay on their winter's supply of fat, eating principally sand eels, and the small fry of sea-fish. They also will sometimes eat fresh-water fish (see Appendix).* They do not care to feed when on the march. I have examined the stomachs of hundreds of salmon, and found rarely anything in them but intestinal parasites, and these often in abundance. I have, however, on two occasions found the semi-digested remains of herrings. The teeth of the salmon are certainly rapacious; and from the teeth the food of the animal ought, by a comparative anatomist, to be pretty well predicted. Thus, the teeth of the rapacious shark are as different from those of an herbivorous fish, such as a tench, as are the teeth of a lion from those of a billygoat. The salmon has rapacious teeth $\uparrow$ round his jaws, and if the observer will pass his finger some distance down the throat of a semi-dead salmon, he will find that it will be sharply pinched by a set of needle-pointed æsophageal teeth which are fixed into the skin of the gullet, and which break up and comminute the food which has been captured by the teeth set along the edges of the jaws.

* "Transport of Live Salmon from Worcester."

+ These teeth show no peculiar microscopic structure. My friend Mr. Henry Lee and myself once thought we might tell it trout from a salmon by a section of the tooth, but this test will not do. 
I have frequently taken from the gullets and stomachs of sea trout caught in the nets with salmon, at Galway, the fry of young fish, which had apparently just been swallowed. The salmon, therefore, have the same chance of feeding as the trout, but they apparently do not avail themselves of it, at all events in the estuary of the river. Still it is extraordinary that when in the fresh water they will take the fly. I believe the salmon do not imagine the angler's fly to be a fly in the ordinary acceptation of the term, but simply a shrimp; for if a fly be watched when jerked about by the angler's rod in the water, it reminds one strongly of the quick jerk-like movements and springs of the ordinary shrimp, and therefore I think the salmon supposes the fly to be a shrimp.

Very often he takes it because he is idle, and has nothing else to do but to run at a strange glittering body and see what it is.

I am much pleased to find that this is also the idea of the clever author of the "Life of a Salmon." * The Salmon himself thus writes:-

"I was on the point of suggesting to my companions a movement higher up the stream, when my attention was attracted by what appeared to me a familiar object

* The "Life of a Salmon." The autobiography of the lato Salmo Salar, Esq. Day \& Son, Gate Street, Lincoln's Inn Fields, Price 1s. 
-a shrimp or prawn, or some other small object of the ocean so lately quitted, and which had furnished me with many a bountiful meal. It floated gently over my head, not over bright in colour, but showy, and its hues, which were dispersed uniformly over its body, blended together and formed one harmonious whole. Its movements were short and rapid, and it seemed to be striving, with doubtful result, to stem the somewhat rapid stream. What induced me I cannot say: I was not hungry; indeed I had felt no desire to eat since I entered the fresh water; I was hardly in the mood for play for I felt that the serious business of life was before me; but impelled by some unaccountable impulse, I rose from my resting-place, and attempted to seize it in my mouth. The motion was rapid, but still too slow to be effectual; the creature vanished ere my lips could close on it."

I shall quote no further, as the reader must read the book and see how the adventure ended. The story is admirably told.

When examining the fish as we rowed them in the boat from the nets towards the quay where the cart was waiting, Mr. Miller pointed out there were two kinds of salmon found in the Galway river, viz., the fish of the ordinary colour and shape, and "the black-backed fish." 
The points of this black-backed fish, as compared to the ordinary fish, are as follows :

1. His back is almost inky black, but below the lateral line he is as bright and glittering as any other salmon. 2. His head and general shape is trout-like, the former being often much peaked, and certainly not handsome to look at; the spots on his jowl are large and well defined. He is thicker through the body, but his sides are not so deep as in ordinary fish. The flesh is slightly whiter, but, nevertheless, ten black fish would weigh, on the average, one-fourth more than the ordinary fish. After the middle of June, of the fish caught at Galway, one-sixth are black-backs, but before this time they are only caught every now and then; they have sea-lice upon them, showing that they have come straight from the sea, and they are in as good condition as their white-skinned brethren. Finally, the "blackback" can always be recognised, not only by its colour, but by its shape. Mr. Miller thinks they are a peculiar breed of fish, and differ from the ordinary salmon only as one breed of dogs differs from another; he is also of opinion that they spawn in deeper water than the other fish, viz. at Cong, at the head of Lough Corrib. My own opinion is, that they are fish which have spent most of their lives in dark bog-coloured water, and hence they have assumed the peculiar dark appearance they 
present,* for, as we all know, the colour of the fish is wonderfully influenced by the colour of the water in which it lives. I fancy, therefore, that these fish have been trying to get up into their own streams-the Farbough, the Spiddle, the Inver, and the Costellowhich are not very far off from the mouth of the Galway river; but not finding sufficient water to run up, have come on to the mouth of the Galway river. There is generally enough water for them here, and the drier the summer, the better is the Galway fishery, for the simple reason that the fish of the smaller rivers crowd to the big one for the sake of the greater flow of water. The same thing takes place in Donegal Bay, where in dry summers a great number of fish run up to the Ballyshannon fishery; but in wet weather the numbers of fish fall off, for the simple reason that there is plenty of water in their own streams: the same thing holds good with the Galway fishery.

My theory that these black-backed salmon are coloured

* Referring to Mr. Buckland's very interesting paper, "A Run through Connemara and Galway," I would remark, in humble confirmation of his theory, that I could at a glance pick out from a fisherman's basket almost every trout he had caught on the streams which run through bogs, the sources of these rivers being on the moors in East Cornwall. The trout are invariahly darker-in fact, "black-backs"-and quite inferior, both in flavour and appearance, to the beautifully-coloured fish taken from the rippling clear beds of the Camel or Inney, into which these bog-tributaries flow.-S. S. S. 
by the bog water is, I think, strengthened by the fact, that when examining the fish caught by the nets at the mouth of the Ballinahinch river, I observed that there were a very large number of black-backs; and this river, as I have already stated, is fed by water from off bog land. Mr. Miller has kindly had a photograph taken of a black-back, and of an ordinary fish of exactly the same size and weight as the black-back; he has also sent me a fresh-caught specimen, of which Mr. E. Ward has made a plaster cast, and which Mr. Briscoe has beautifully coloured to life. The photographs and cast are now in my "Museum of Economic Fish Culture," Royal Horticuitural Gardens, South Kensington, with many other casts of useful fish, both of sea and river.

In the autumn large male fish in most rivers assemble together, somewhit after the fashion of deer, and prepare to run up to the spawning-beds in shoals. In some places the autumn fish are as red as foxes, and are called "red cocks;" in other places (as on the Suir at Tipperary), they are called "grey cocks;" in the south of England they go by the name of the "blue cocks;" on the Blackwater, co. Cork, they are called "blackberry fish," because they come at the time of the blackberries; and on the Tweed they go by the name of the "grey schule." I had the above from my friend SER. III.-VOL. II. 
Mr. Ffennell, who seemed to think with me, that these Galway "black-backs" are "bog-water fish."

Amongst the fish caught at Renmore Point, every now and then we caught some regular Paddies, who, I imagine, had either been inoculated with the national love of fighting among themselves, or else had escaped the persecution of their enemies. These fellows had got scars all over them, but principally on the tail behind the dorsal fin; they were long scratch-like wounds, as though the fish had been touched with a red-hot gridiron, and the wounds half healed up afterwards; one fish I was lucky enough to find had just come out of a row, for his tail was scarred all over as though he had been cut with a surgical cupping machine. These are of course teeth marks of voracious fish. That the salmon have plenty of enemies in the sea we all know, and I regret to say I have a pretty long list of them. The angler-fish (Lophius piscatorius) catches a large number of young smolts-young inexperienced salmon, who enter the sea for the first time in their lives-in its capacious mouth, attracting them by means of its curiously-contrived rod and floating bait. (See cast and preparation in my museum.) This, I believe, particularly holds good as regards the estuary of the Severn. I could not, however, make up my mind what enemy had scarred the backs of these Galway salmon, till, returning from the nets, I passed through the fish- 
market in the town, and here my eye fell upon a boat from which the fishermen were tumbling out a large number of gigantic hakes. On examining the teeth of these rascals, I saw that they would cause just such wounds as I found on the salmon; and I believe, therefore, that if we regard the matter as a question of medical jurisprudence, a "true bill " might be returned against the hakes "for maliciously cutting and maiming with malice aforethought."

Another result of my examination of the salmon caught in the net revealed the existence of a worse enemy even than the hake.* One poor fish had the left gill and about half his head just hanging on to his body by a bit of skin; another had a great rip in the side, an ugly wound; another had his nose completely smashed off, and some few had 'anglers' flies sticking in their mouths. In two the flies had evidently been in the fishes' mouths a long time, and rod fishermen will be pleased to hear that these fish had in no way fallen off in condition, and that, ulceration round the hook having taken place, the hook would eventually fall entirely away from the fish's mouth. The poor fish which had had his nose smashed in-and I saw three or four

* A friend of mine lately pounced suddenly down upon a poacher on the upper waters of a river. The poacher had a codhook in his possession, and of course was after salmon. In his fright the poacher declared he was "only fishing for cod"-this in a little stream among the hills forty miles from the sea. 
others in this condition during a fortnight's watching at the nets-had evidently made too close acquaintance with a mill-wheel, but the other wounds I have mentioned had been inflicted by what are locally called "snatches," or "stroke-hauls." I have now in my museum a collection of formidable and cruel instruments (like the instruments of torture exhibited at the Tower of London) which have been taken from the fish caught in the net. No. 1 is an ordinary fishing fly; round the shank of the hook is twisted some heavy strips of lead; the twisted gut above is also armed with a strip of lead. This is thrown in an ordinary way from the rod where the water is shallow, and as it sinks down among a shoal of fish, is snatched suddenly through the water on the chance of hooking a fish foul, and I fear it too often succeeds in so doing. No. 2 consists of a sea-fishing hook, tied on to a twisted gut; about three inches above the hook is attached a small bullet; this, too, has evidently been thrown by a rod, as there is a piece of excellent plaited fishing-line attached to it. No. 3 is a terrible-looking instrument; it consists of three very strong cor-hooks, tied in the shape of a triangle on to a piece of common string, and heavy lead is twisted round the string for eight inches above the hooks; it acts on the principle of a grapnel, such as is used for recovering the bodies of drowned people, and is a terrible destructive instrument, as it 
wounds more than it catches. No. 4 is a hook as large as a small gaff-hook, and to the string a little way above it is attached a heavy piece of lead, weighing a quarter of a pound. I strongly suspect that this is the identical hook that nearly tore the poor fish's head in halves, for it was taken out of another fish by Turk (one of the fishermen) the day after I examined the specimen in question. How these latter instruments got into the fish, I shall explain hereafter.

The employment of these instruments is cowardly and unEnglish-like, and the users of them ought to be served in the same way as a certain English officer served a John Chinaman. He was asleep in his tent, ard waking suddenly up, he saw a Chinaman stealing from his table. He ran after him, luckily picking up a fish-gaff as he passed out of the door. Seizing the Chinaman's clothes, he essayed to pinion him, but the thief's garments slipped off his body as suddenly as does the drapery from a statue at the inauguration thereof. The pursuer then tried to seize the flying Chinaman by the waist; but the rascal had oiled his body so perfectly that he was as slippery and as difficult to hold as a greased pig at a country fair. He then caught hold of his long pigtail; but the fellow had filled this with pins and needles, and other sharp-cutting instruments. In a fit of desperation, and as the thief was likely to escape, he said to himself, "Well, if it comes to this, I 
must gaff you, so here goes." Lunging well forward, he plunged the gaff into the Chinaman, and brought him up suddenly "by the run." The fellow cried ten thousand murders, and called upon all the saints in the Chinese calendar to deliver him from the infernal machine of this Hang-qui-lo, or European white devil. 


\section{MILL-WHEELS.}

EXPERIMENTS ON SALMON, ETC.

I wish now to say something about the great injury which mill-wheels do to a salmon fishery. Fishing on Monday morning at Renmore Point with the nets, I observed that several of the fish looked very thin and out of condition, as though they had been ailing for some little time past. The cause of this is as follows :-

The salmon which escape the nets when the water is low go up the river, and, meeting with the mill-races, where the water comes down much more rapialy than it does down the main stream, naturally imagine that the mill-stream is the channel which will lead them to the upper waters; they go up this as far as they can, and frequently press up so close to the revolving flaps of the wheel that they receive fearful blows on the head. At Galway there are mill-wheels situated several yards at the further ends of long dark cellar-like arches -like the Adelphi arches on a small scale. The mill- 
race which empties itself into the Galway river just above the bridge on the right-hand side (looking towards Lough Corrib) is no less than 300 yards long, and there are six arches at the upperen $I$ of it, each arch being 30 yards in length. The fish get up into these arches, and there stay for a whole week, of course being obliged to keep up their steam continually in order to hold their own against the rapid stream.

But they have worse enemies to contend with than the stream and the wheel, and these are the millers' men. The proprietor of the fisheries-to whom the fish belong as much as a farmer'spoultry in a farm-yard belong to the farmer-knowing that these millers' men are in the regular habit of poaching the fish in the dark arches, places watchers at the mouths thereof. These men are on duty day and night, and their sole business is to stare up the arches and see that no poaching goes on. The millers' men nevertheless watch their opportunity, stop the wheel suddenly, and getting down into the dark arches, strike right and left with the formidable gaffs and other instruments above described at the fish, now helpless in shoal and almost stagnant water. 'The watcher, perceiving that poaching is going on far up in the dark arches, endeavours to creep up and identify the poachers. Seeing the keeper coming, the millers' men crawl away as quickly as they can scramble by the side of the wheel up into the mill, and 
then turn on the water suddenly, sending the full stream down through the dark arch. If the keeper be not quick enough to get out of the way before the water reaches him, the stream will strike him, instantly trip up his feet from the slippery boards, carry him into the river, and drown him. Watching mill arches is therefore very dangerous work.

Many poor salmon therefore are grievously wounded by the millers' men with the "stroke-hauls" and other forms of gaff. Some escape with the instruments still fixed in their bodies, and fly wounded and bleeding for refuge into the river, where, if not caught by the nets, they perish miserably. Thus, then, I account for the formidable poaching instruments which I described a page or two back, and which were taken from the bodies of the fish caught in the nets. An incessant war and bitter hostility is, therefore, going on between the watchers and the millers' men, to say nothing of the evil effects to the men's morals, who have always before them the temptation to steal for the sake of obtaining drink.

The salmon, even if they are not gaffed, suffer materially under the mill wheels. It may have been observed that I stated that the mill-race fish whose condition had been injured were caught generally on a Monday morning. The reason is, obviously, that when the mill is shut off on Sunday, and the water stops, 
they find out their mistake, i.e. that they are not in the main stream; they therefore drop back into the river, and are caught in the net some ounces lighter than they were a week before. Mr. Miller assures me that the money damage done to Mr. Ashworth's fishery from this cause and the poaching by the millers' men amounts in the year to a very large sum.

The remedy for all this is obvious: it is simply to place a grating at the mouth of the mill-race in order to prevent the salmon ascending, and so to do away with the temptation of poaching and stealing. The millers, however, object to grating of any kind being placed at the end of the mill-race, upon the plea that it would block back the water, and interfere with the action of the mill-wheel.

When I was examining the models, \&c., deposited by the fishery commissioners at the Exhibition at Dublin, Mr. Brady was kind enough to show and explain to me several contrivances which had been proposed to prevent fish running up mill-races. The first was invented by Mr. Eden, late Inspector of Fisheries, and consists of a cruive or V-shaped grating, placed the wrong way. A salmon is rarely known to go out of this trap as it is set in the regular weirs for the purpose of catching him. It is argued that when the cruive is set the reverse way, he will not go into it. The weeds would at the same 
time have space to pass between the bars and into the stream.*

The second plan is proposed by my learned and highly-scientific friend Dr. Carte, Professor of Natural History of the Dublin Royal Society. It consists of a wheel made of light wire, like the turning-barrel of a squirrel's cage. It is intended to revolve perpetually in the water. 'The weeds lodging against the wheel would cause it to turn and let them out, while no salmon would be strong enough to push the wires in the opyosite direction and thus get access into the millrace.

Mr. Brady's invention consists of a moveable bar, through which spikes are run at right angles, just like the chevaux de frise round the cannons on the Horse Guards Parade. This water fence is hung very lightly at the two ends, and when the weeds come they force it up, and they themselves swim through. The fence then falls by its own weight, just as does the wire slanting door to the ordinary rat-traps; through this the rat can easily crawl, but it never lets him pass out again.

In "Land and Water," No 53, Jan. 26, 1867, my friend Mr. B. Woodman published the following :-

* This plan has been adopted by my friend Mostyn Owen, Esq., Hon. Sec. of the Dee Board of Conservators, to keep the salmon out of the salmon trap at the Chester weir. 
"I send you a sketch of a tail-race guard, recently designed by one of the water-bailiffs of the Coquet Fisheries Association. The sketch is intended to represent a model of the guard, as submitted to a meeting of the above association held on the 8th instant.

\section{FIG. 1.}

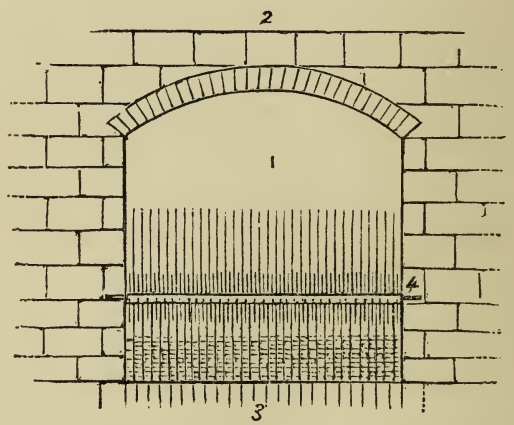

3. Represents the guard in motion. 2. Top of mill-race. 3. Tail-race 4. Projection of axle of guard inserted in arches in the walls confining the mill-race.

"The guard, as shown in the drawing, has four arms set at right angles to each other, is suspended by bearings inserted in the walls confining the mill-race, and is composed of small rods set at such distances apart as to prevent the passage of salmon. The bed of the tail-race is scooped out (if I may use the word) to a radius a little larger than that described by the guard in rotating, and is, I suppose, by this intended the more effectually to answer its purpose, though I do not for 
my own part clearly understand why the flat surface of the tail-race should not answer, because one arm of the guard would, as nearly as possible, be always perpendicular to the bed of the tail-race; but I am of opinion that instead of four arms, six would answer

Fig. 2.

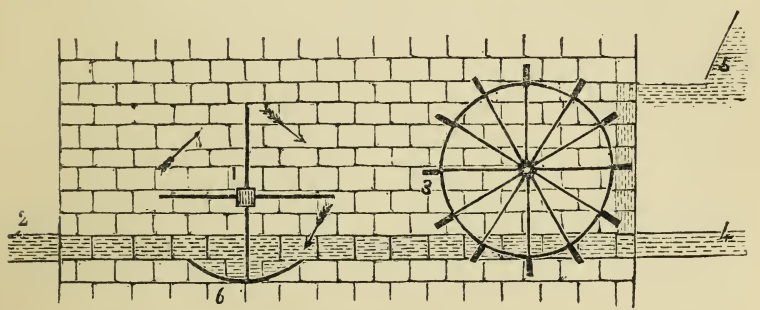

1. Guard. 2. Race joining the river. 3. Mill-wheel. 4. Water level in tail-race. 5. Ordinary water level. 6. Hollow below the ordinary level of tail-race, made to allow of revolution of tail-race guard.

much better, and would still further dispense with the necessity of interfering with the bed of the race by hollowing it out as just mentioned.

"The guard will acquire motion by the action of the water, as the ordinary mill-wheel does. From its construction, that motion will undoubtedly be sluggish, though increased irregularly by the accumulation of weeds and other floating rubbish passing down the race. Even were the guard not to rotate generally, say only when the pressure of accumulated rubbish became great, it would not matter in the slightest degree. In fact, I would suggest that the material and form of the 
guard be such as would offer the least resistance to the water-to impede, through slow rotation, and so prevent injury to the fish by collision with it in motion.

"I also send you another sketch of the same guard, in what I have imagined to be something like its proper position in the race when in operation, and I hope that by the help of both sketches, imperfect though they may be, you may be enabled to arrive pretty definitely at the object of the inventor. Of course it is only intended in writing on this subject to lay down a principle. I give no positive opinion as to the form or position .of the guard, believing that by your own personal assistance and the additional assistance of a complete ventilation of the subject in the columns of "Land and Water," its merits or demerits will be clearly established. I therefore beg to ask you to take the subject into your consideration, and that if you do so, you will kindly give a sketch of the design, as that will probably lead to criticism and improvement of it.

"Benj. WoOnman,

"Clerk to Coquet Fisheries Conservaney, Morpeth."

The objection, however, which would of course be urged to the various and ingenious contrivances invented by the above-named gentlemen is that, even if they let pass all the weeds and rubbish, they would throw the water back upon the wheel. I am not 
engineer enough to know what amount of interference with a stream could be allowed below the wheel without doing danage to its working power. The following calculation will, however, give some idea of the amount of water that would be thrown back by bars :-

Supposing the arch of the mill-race to be forty feet across, and a grating to be placed, made of iron bars half an inch thick and two inches apart,* the total space occupied by the bars would be eight feet; and I fear the millers would not like this eight feet of the forty feet width of the water course to be backed up on to the wheel.

In talking over this matter with Mr. Ffennell, he informed me that he had for a long time been endeavouring to get the proprietors of mills to adopt a plan of his own, which he kindly allowed me to mention in this place. It is, to have a net made of the same strong material as formerly used in stake-nets; the net to be of a funnel shape, and from ten or twenty yards long, according to circumstances; the upper end or mouth of the net should be affixed to posts driven into the bed of the main river, at the point where the millrace enters it. The free end of the net should be made round and barrel-shaped, and wide enough to admit a

* I find a 91b. salmon is just about three inches in thickness through the thickest part of the body, a two-inch grating would therefore be sufficient to stop him. 
man's body, so that the weeds and rubbish could easily pass through it; the salmon coming up-stream could not possibly get through the meshes of the net into the mill-stream, nor yet would they be likely to enter the wide aperture at the end, as it would be continually swaying backwards and forwards in the river, and they would never find their way into it. I trust that this hint may be useful to fishery proprietors, and that it may be tried practically. Mill-races differ much in circumstances: in some the stream is greater than in others, in some the fall is more rapid; in some there - may be difficulties in fixing the net, in others none. Mr. Ffennell, however, felt confident that the principle of keeping the fish out by means of a floating net will be found to be of great service, and we both agree that it is a subject well worthy of inquiry and discussion ; and in the case of any grate or net being fixed at the mouth of a mill-race, that it should be officially inspected by a competent engineer, so as to give satisfaction to all parties concerned.

In "Land and Water," No. 92, October 26, 1867, I published the following:-

"The diligent student of salmon cultivation should, I think, never be above learning even from a poacher, and many useful hints may be obtained from this class of society which we salmon preservers may apply to legitimate purposes. Talking the other day with a gentle- 
man who has been salmon angling in Norway, I was told that the Norwegian peasants sometimes adopt a very artful plan to cause the ascending fish to remain in the particular pool which they have a legal right to net. They get boards and make them into a large square. They then place these on the shore; a bend in a river just above a deep pool being the place best adapted for it. They then paint this board quite white, I imagine whitewash would do as well. The salmon (so I am told) will not pass by this board. The idea of the Norwegian fishermen is that the salmon think this board is an impassable waterfall. For my own part, I believe they are frightened at it, thinking possibly that it is a ghost. However this may be, the commanding officer of the squadron sounds 'Halt,' 'Prepare to rest,' 'Rest,' and the foolish things do rest till the net comes its rounds, and they all are taken prisoners of war.

"Now, why should not we, friends of the salmon, apply this plan not to catch the fish, but to prevent them being caught by 'the jolly miller and his men,' or being injured by the mill-wheels. It strikes me that it would be a good plan to whitewash the walls at the lower ends of mill races, and also to place a large white board right across the stream, or even in the water itself at the point where it is diverted from the river by the weir.

"The 'up fish' attracted to the mill-wheel by the SER. III.-TOI. II. 
predominating current would signal to their friends ' No road here; there's a ghost;' and the poor enfeebled kelts, the 'down fish,' being invalids and out of health, and therefore of a nervous constitution, would be more frightened still, and making their way up from the fatal mill would prefer, to facing the dread apparition, chancing a down-hill tumble over the mill weir above, just where we want them to go. The silly little smolts would, of course, see the white monster in the water as they are going down to the sea, and think it the shades of their departed ancestors, killed by the ogre, the - miller, under his wheel. The grilse would, under some rock in the river's estuary, hear from the old grandmother salmon the legend of the ghost at —— mill, and carefully run past the place as fast as the benighted villager runs through a church-yard which is supposed to be haunted. Besides the walls of mill leats, both at their exit and entrance, being whitened, I should also advise a whitened skull, say of a horse, or better of a cow - the horns would make it more terrible in appearance - to be thrown into the water with a view of frightening the fish, and keeping both young and old out of danger. I, would feel much obliged if some of my friends among boards of conservators would try this plan, and report thereon."

I have stated that a salmon very seldom gets out of a cruive when he is once in it, and this very fact has 
afforded me considerable amusement. The first thing I did every morning, while I was staying at the fishery house with my friend Mr. Miller, was to run out and examine the cruives to see if any fish had gone into them during the night. The water is so glassy clear at Galway, and it is so chemically pure, that one has a peculiarly favourable opportunity of examining a living salmon at leisure.

The first thing, on looking at these beautiful living fish in the cruives, that struck me, was their peculiar colour when in water and examined from above. I think we anglers and naturalists generally place the dead fish in his wrong position when we wish to look at his proportions. A fish does not swim on his side, but yet we generally put him on his side to examine hin: we should rather place him so as to look down upon his back, for the fish's side is never seen when he is in the water. A salmon on a fishmonger's slab looks silvered and bright, but as we look down on him alive in the Galway fish-trap, he appears to be of a red mahogany colour, beautifully spotted with black marks, not at all unlike a dark-coloured leopard; no silver colour at all is visible about him. The salmon's eye is so situated in his head that the vision shall be directed upward and forward; and it projects considerably beyond the level of the head.* I do not, therefore, think

* This is better seen in the living than in the dead fish. 
that a salmon can well see what is going on behind his head; butfor an object floating down-stream towards him, his eyes are great magnifiers. I have made a dissection of the eye of a salmon by running a sharp knife behind the cornea. Then placing the crystalline lens upon a piece of newspaper, I found that it magnified the type to an extraordinary degree, even to a greater extent than a pocket lens. If, again, a lens freshly taken from a fish, be suspended on a needle point, and held between two observers, so that each looks through it, the effect will be found to be most curious and comical.

- It struck me, when I was watching the salmon, that it was extraordinary how the fish could hold his place against the stream. I therefore wished to find the cause of this. The body of the salmon is one solid mass of muscle, and the muscles are devoted to one purpose, viz., that of swimming, though he has also the power of jumping. Still his weight when swimming in the water must count for something; I therefore took the opportunity of weighing a salmon just rapped on the head with the killing-stick. I suspended him by the back fin to an ordinary angler's weighing-machine and weighed him, first in the air and then in the water. In water of the specific gravity 1.0015 (i.e. slightly brackish), a 9lb. fish weighed one quarter of a pound, and a 4lb. fish simply nothing at all. In fresh water at 1.0005, at a temperature of $64^{\circ}$, a $19 \mathrm{lb}$. fish weighed $1 \frac{1}{4} \mathrm{lb}$. only. 
Thus we see that in reality a fish has very little weight indeed to carry when in the water, and we begin to understand how (his weight being comparatively nothing) he is enabled to apply the whole muscular force of his body to stemming the rapid streams in which he rejoices to live.

It then occurred to me to try what was the traction power of a salmon when pulling in the water. Having obtained permission from Mr. Miller to try the experiment, I let nyself down into the cruive, where three fine salmon were swimming about. The moment I was in the cruive they began dashing about like frightened sheep in a fair. I selected the biggest fish for the experiment, and when he was a little tired crept slowly and cautiously up to his head and as he lay in the corner quietly slipped over him a set of leather harness which I had made on purpose to fit his body, the action of the pectoral fins not being interfered with. I then attached to my waist an ordinary weighing scale, ${ }^{*}$ and fastening the traces of the salmon's harness, which were swimming loose in the stream, to the hook of the weighing machine, stirred him up suddenly. In a moment he plunged forward like a thoroughbred colt the first time he is put into the break, and in an instant smash went my harness all to ribbons, and my scaly steed bolted away like a mad fish, the traces dragging after him all

* Pocket-scales, the weighing part of which pulls out. 
round the cruive. Query, how did Father Neptune harness the dolphins to his triumphal car. Deternined, however, not to be beaten by a salmon, I got a stout piece of cord, and after some difficulty, as the fish was getting very artful and shy, managed to slip it over his tail; so getting a firm hold with the cord of what the fishermen call the salmon's " wrist," * and kneeling down in the water, in order to give him fair play, I stirred him up again with a switch. The first plunge pulled the weighing scale out to 23lb.; the successive plunges were 20lb.: and then 15lb., and then hardly anything at all. At last he seemed exhausted, and showing his white side, allowed the stream to carry him broadside on to the bars of the cruive, a sure sign that he had had enough of it. I much wished $\mathrm{Mr}$. Rarey had witnessed this experiment in breaking a salmon colt into harness; I think we should have had some fun about it. From this and repeated observations of the same kind with other salmon in the cruives, I am convinced that a salmon's escape from the angler's hook depends much upon the first plunge he makes, and that although his power to go against the stream be very great, yet he is very soon what is vulgarly called "done," if called upon to make extra exertion.

I regret much that I was not able to bridle a salmon

* That part of the salmon between his tail and the adipose or dead fin. 
or place a hook into his mouth. I tried to do it several times, but he was too quick for me. All the reward I got for my pains was a sharp scratch on the finger from one of his teeth, when I got it into his mouth trying to put on the bridle.

The following year, when at Galway, I harnessed three salmon and drove them some way down stream. They "jibbed" tremendously, and continually turned ruund and stared me in the face like the leader in an Oxford tandem. We tethered them all night, with string through their gills. The next day I carried seven live salmon from Tuam to Galway in a big box full of water; but it was terrific hard work. We wanted them for spawning purposes.

Mr. Miller had kept ten hens and ten male salmon in separate boxes, moored in the river. The night before my arrival a flood took away the box containing all the gentlemen out to sea; I was obliged, therefore, to get more male fish, or the hatching season would have been lost entirely for the year. We, however, did not lose the season. It was Christmas-week when I performed this task, and, though pretty hardy, I suffered much from wet and the intense cold.*

While I was trying my experiments with the salmon in the cruive there were two others crouched up into the

* See also my account of a journey with a salmon from Worcester, in Appendix. 
corners, and evidently afraid their turn would come next to be put in harness and made to draw. I managed to crawl very gently and quietly alongside the biggest of these fish, and after several trials succeeded in placing my finger on the point close to which I knew the heart. was situated. I could feel it distinctly beating and thumping through the skin on to the end of my finger. I then requested a friend standing upon the weir to take out his watch, and we thus ascertained that the pulse of this salmon beat 92 to the ninute. I then tried the other fish, and found that his pulse was 103 to the minute. I also counted their respirations or the movements of the gills in breathing; the first fish respired 77 times in a minute, the second fish 79 times in a minute. I must, however, state that these fish had been running about the cruive whilst I was trying my experiment with their relation, and I dare say they were in a bit of a fright, and their pulse beat quicker than usual, as I know from experience the pulse of a patient who comes to consult the doctor is often bounding away at a famous pace from pure nervousness.

When a salmon is knocked on the head by the killing-stick, he is generally dead in about a quarter of a minute; being anxious to know, per contra, how long a salmon would live out of water when time was given him to die uninjured, on another occasion, I quietly, and without hunting him, slipped a large landing-net 
under a 10lb. fish which had just come into the cruive of his own accord. I then suspended the landing-net in such a manner that he could not injure himself, and I was rather surprised to find that he ceased kicking in about seven minutes,-eleven minutes elapsed before he was perfectly quiet and dead. The temperature of the air was about $68^{\circ}$; if the day had been colder, I think he would have lived much longer.

The water of the Galway river being so remarkably clear-the specific gravity was only 1.001-and at the same time very low, when I visited it, I have been enabled to make other observations on the salmon. One of the chief characteristics I observed about the salmon was, that its nature appeared to be as much gregarious as that of sheep or oxen. This, however, is not always the case, but obtains only at the time of their ascending the rivers. I have watched for hours large numbers of salmon in the river between the bridge and the weir at Galway, and hardly ever saw one entirely by him or herself. They like to make up family parties; and their favourite position seems to be side by side, their fins almost touching, like cavalry horses in the stables at Aldershot; and when one of the party goes away he soon comes back and "falls in" with a regularity that would do credit to a soldier. Ore very bright Monday morning I counted in the space from the bridge to the weir, which is not more than 150 
yards, about 280 salmon, there or thereabouts; they had divided themselves into family parties, and were in consequence not very difficult to count. The sentries of the parties, alarmed by cur presence, perpetually shifted their ground, and (like the country boy's little pig that kept running in and out among the other pigs) were therefore very difficult to add to the calculation.

The following fact seems to confirm my idea that the salmon are sociable beasts, and I think I might almost say pair like birds. One morning early I observed two fish resting in the stream under the wall of the weirthey were possibly male and female, for I am not at all sure but that salmon pair off early in the autumn-I stole up on hands and knees, making myself as flat as possible, and watched them for a long time, thinking what pretty creatures they were; at length one of them saw me, and dashed right away. I remained perfectly quiet, and after a while saw this same fish at a distance gradually piloting himself back again, like a Great Western engine feeling its way into the Paddington Station when the danger signal is up. Thinking the road clear, he gradually dropped himself down into his old position and lay alongside his friend, who, by the way, had never moved at all. "Halt-front-dress," said I, to the salmon. The fish obeyed the word of command; he "dressed up" to an inch, and there these two beautiful creatures lay side by side like babes 
in a wood. A few minutes afterwards my fidgety friend took himself off again, and made a second reconnaissance of the neighbouring waters, once more dropping back into position. Still I remained perfectly quiet; then I cannot help thinking that this nervous salmon communicated his fears to his less timid companion, and whispered into his or her ear that the ogrelike monster that was gazing at them from above was " no good." His warnings evidently had effect, for all of a sudden, without giving any notice, they both darted away together, like arrows from a bow, and I saw them no more. Whither, oh whither away, ye mysterious pilgrims of the waters? May good luck attend ye in your perilous voyage-

"From the black shores of the sea, to the lands where the Father of Waters

Seizes the hills in his hands and drags them down to the ocean."

In a former page I gave some account of the gregarious habits of the salmon when on the march from the sea to the spawning-beds on the upper lands. These curious fish, however, do not appear always to keep together in droves or flocks, for when the actual spawning-time arrives, by a wonderful instinct, each fish seeks a place where to build its own nest, and for this purpose they distribute themselves over hundreds of square miles of country, scattering their numbers in all directions, like bees flying on honey-collecting 
expeditions from a hive on bright sunshiny days, nature's object evidently being to scatter the supply of young fish over as large a tract of country as possible. The herding tendency of the salmon can, however, be again observed in the smolt on his way to the sea; and a friend of mine, who has been a great observer of the habits of salmon for many seasons, has a very curious theory as to the way the smolts get through their seaward journey. "They go," he says, "with their heads pointed up-stream, and working their tails gently against the current, sway themselves backwards and forwards, tacking, as it were, like a ship, to and fro in the water, but still always dropping downwards." The consequence is-and it is a most ingenious theory to account for the salmon returning to the rivers where they were bred (which I believe they do) - that the young fish know their way back again to their own former homes, when they come back as grilse. Thus, on returning up-stream, they would see this rock and that rock, this stump and that stump of a tree, and other water-marks best known to themselves, just in the same positions as they saw them. when they went to the sea; whereas if they performed their downward journey head foremost, the whole position of the objects they passed would be reversed as they returned. I give the theory as it was told to me. I think, lowerer, that the same wonderful instinct present in migratory 
birds, and also in migratory fish, has much, if not everything, to do with the return of salmon to their own waters.

Again, when the smolts arrive at the edge of a waterfall they sound a halt, and, backing gradually towards the point where the water flows over, hover to and fro at the edge, and then swiftly swim up the stream again like swallows skimming round a steeple tower hawking for flies. At last, one of the more daring of the smolts lets the water take him over the fall, and the others at once follow like a flock of sheep going through a gate into a pasture-field. But mark the position of the young fish when he takes his fall, for it is tail first and not head first; the consequence is that, should he happen to alight on a rock below, his flexible tail being light and elastic, causes him to rebound from the rock and receive no injury.

If he went down head foremost he might possibly meet with the same fate as happened to a fine young soldier of a light cavalry regiment when I was quartercd with the 2nd Life Guards at Aldershot. He was a gocd swimmer and fond of bathing, but unfortunately did not know the water. Arriving in a great hurry one very hot day at the side of the canal, he asked some soldiers who were standing by if the water was deep, and on their replying very wrongly in the affirmative, he took a long run and a graceful header into the canal. Alas! 
he had been misinformed; the water was only about four feet deep, and the poor fellow's head hit upon the bottom with the force of an artillery rocket, killing him in an instant by fracturing a vertebra of his neck. I do not mean to say that the same thing would happen to the salmon as happened to the poor soldier, but still it is curious to see how nature anticipates violence to the tender body of a young fish in going over weirs and waterfalls on his road to the sea, by making him go tail, and not head, foremost.*

* Mr. Buckland refers to the fact, that fish when going orer a fall of water drop down tail foremost, and by so doing they run less risk of injury than if they took a " header." Doubtless instinct teaches them the best means of descending, but I venture to think that the same cause which makes them slowly descend a river with the head directed up the stream, also compels them to go over a dam in the same manner. I refer to the freedom with which they respire in this position. If I am right in the notion I entertain of the respiratory act of a fish, it is not precisely like the same act in mammals. In the fish, as soon as the mouth is opened, the water rushes in to fill the racuum so formed, and then, the mouth being closed, the muscles (pharyngeal?) contract, and send the fluid out orer the gills. The water thus falls in with the general current, and is carried off; on the other hand, if the animal has to pump the water back against a strong current, the muscular effort to do so must be increased manifold (?), and the creature must feel more or less of what we call dyspnœa. Boys know this fact; they talk of drowning a fish by keeping his head down the stream. Again, as a trout or a smolt has very little backing power, if it takes a " header," it must necessarily go down with much greater velocity and increased chance of hurt than if with tail and fin it main- 
There must exist in fish some wonderful power of which we who live in the air are not cognisant, viz., the power of avoiding obstacles in water; for who ever saw or heard of a fish, even when frightened out of his wits and scudding away with the utmost rapidity from an enemy, dashing his head against a rock or stone? They seem to thread what to us appears the most intricate

tains its grip of the current to the utmost verge; thus doing as a boy about to rob an orchard, who holds on by his hands to the fence and so drops down, so also diminishing the effect of gravitation by how much the body is brought nearer to its station before the jump is taken. But I am not quite satisfied that a fish falls tail foremost, and think it not improbable that during the fall, it may (as a cat does) slue around to some extent, so as to form some knowledge of the abyss and guard against a smash. My experiences are only amongst trout, the rivers in the west of Cornwall having no salmon, and but few salmon peel as we call them. I have noticed that when trout are disturbed, they either take a short swim, and then turn around to breathe freely in a still place, where the current is not strong enough to embarrass much their respiration - or if the current is strong they make a tremendous rush through the rapids, and bring up under some quiet bank in the pool below. They would, I think, quickly die if held with the head down stream in a rapid. When a fish is going over a mill-dam it holds on with every power it possesses, and with the same tenacity which Genffroy is said to have done in the old romance, who grasped the castle wall with his hands, and when those were chopped off, held fast with his teeth, and when he was decapitated the rigor mortis came so promptly that both head and hands maintained their grip after the trunk had fallen to the ground. "If this legend is not true it is well imagined."-J.H. NANKWELL (M.R.C.S.).-In Land and Water, No. 63. 
labyrinth of weeds, stones, and all kinds of obstacles with the agility of a woodcock threading the thickest underwood. I cannot help thinking that the fish feels his way in the water by means of some curious power analogous to that possessed by people who have the misfortune to be blind, or a bat flying about among trees and rocks in the darkening shades of the evening. As regards the much-disputed question as to how long the smolts remain in the sea, I have the following cases to put in as evidence. Mr. John Miller, of Galway, tells me that salmon were bred artificially at Doohulla, and upwards of $\bar{\tau}, 000$ of them were let loose in the river; none of these fish came up that same year, but the next year 130 were caught and over 100 were marked; there had been no salmon in the river before, therefore these must have been the same fish.

At Ballysodare, several hundred smolts were marked in May, 1858. In June, 1859, twenty-four of these fish were caught as they were coming up, and twentythree were marked fish. They averaged 4lb. weight each. This goes not only much in favour of the idea that smolts, even when they get to the sea, are gregarious, going and returning in flocks, but goes far also towards proving that the smolts, at all events some of them, remain but one year in salt water.

The other case that I have to place on record, is that 
kindly sent me by Mr. Alexander Miller, of Chepstow, who writes as follows:-

"Chepstow Salmon Fishery, Fish House, "Aug. 10, 1864.

"SIr,-I send for your inspection two grilse caught on the Wye at Chepstow, marked by cutting off the dead fin.

"We marked 170 'lastsprings' (or smolts) going to sea in the spring of 1863 , by cutting off the dead fin and leaving a peak to insure our mark. The two fish now sent to you bear the mark we made-at least one of them can be recognised, the other may have had an accident. Each of these fish weighs 5lb.; one was caught last night, the other this day.

"I may mention we caught another grilse last Thursday (4th), having the same mark, namely the dead fin cut off.

"We are quite satisfied as to these being the identical fish marked here at Chepstow by us.'

$$
\text { "(Signed) Alex. Miller." }
$$

I have carefully examined and made casts of these two fish, and, as far as I can judge, I have every reason to believe they are fish which were marked in 1863 as smolts and returned in 1864 as grilse. Both Mr. 
John Miller, of Galway, and Mr. A. Miller, of Chepstow, intend making further observations. These two cases they now are good enough to allow me to make public are most interesting and instructive; their observations do them much credit.

My own faith as regards this curious question is, that some of the smolts stay one year in the sea, some stay two years, and possibly more. Individual observations are of the utmost importance, yet we should, I think, look at general principles as well.

It appears to me to be a law of nature that the salmon (say in an individual river) shall never be all subject to the same influences at the same time, and this as a protection against their numerous animate enemies, as well as pollutions. To take the case of the smolts alone - supposing the smolts going down the Galway river in the spring of 1864 , were all in a fit condition to come up from the sea in 1865 , it is possible that some cause or other might destroy them all, and thus the whole produce of one breeding season be lost to the river. Nature, however, seems therefore to say, "I will send some of you youngsters up the river in $\mathbf{1 8 6 5}$ and some of you shall stay in the sea till 1866 ; so that if the first lot of you get destroyed, there will still be a second batch on hand to take your places and keep up the supply in the river for future years."

Again, in our own species, we do not all take our stand 
in the battle of life at the same age. Some boys are sent to "cut their own grass" at eighteen, some not till twenty-two or twenty-three. Young ladies, as well, do not always "come out" into society at exactly the same age.

As with girls and boys, so with young salmon; the former do not all begin life at the same age, the latter do not all make their first ascent of the river at the same period of their existence.

As regards the age to which fish live, I beg to place on record the following:-

In December, 1852, Mr. John Miller marked several salmon, and ever since an odd one of this lot has been caught every year in the Galway nets. This spring (1864) one of these same fish was caught with rod and line; now supposing him to have been three years old when he went down as a smolt, that would make him fifteen years old when he was caught, and in this time he had attained the weight of 19lb. We are, however, still very much in the dark as to the growth of fish after the grilse statc, but I trust we shall find it all out some day.

I know there is a difficulty in placing a mark upon a fish; this marking, in my opinion, should never be placed near the tail of the fish, from whence, as we all know, he derives his motive power, just as a screw vessel goes along by means of her screw. I would 
therefore suggest that a piece of silver wire, such as is used in surgical operations, should be attached, either in the form of rings, like the twisted rings of African gold wire we see occasionally, or else simply bound loosely in a corkscrew fashion, round the first ray of the back fin. This fin's duty is to act simply as a balancing-fin to the fish; a twisted wire ring, therefore, attached to it would not interfere nearly so much with the action of the fish in the water as if it were fastened to his tail.

Again, whereas surgical experience shows that in animal tissues the marks of burns from fire are extremely difficult to eradicate, I would suggest that the gill or other part of the body of the fish should be touched with fire and an eschar formed. The difficulty of doing this, at first sight, presents an obstacle, but I fancy I have hit upon a plan of obtaining a brandingiron at a moment's notice; for what is a more easy way of doing this than by lighting a vesuvian cigarlight (which one is sure to have at hand), and therewith impressing a seal upon some part of the fish, say his gill-cover? I have done this on live fish and let them go again; the skin or scales are branded in an instant, and I would guarantee, from my medical knowledge, that the mark of it would never be eradicated. This plan is better adapted for marking larger fish, as grilse, than 
smolts; it can, however, be applied to these if the patient be held for a moment in a dry cloth, and the operation quickly performed. It may be urged that this is cruel, but it is not more so than branding foxhounds (as I have seen done) and forest ponies; and the importance of gaining the required knowledge may be urged as the excuse. Moreover, I really do not think the fish feel it much, for there cannot be many cutaneous nerves distributed on his scaly armour. I have also applied the surgical cupping instrument to a salmon's skin, taking the hint from the hake's teeth marks, and have rubbed lamp black into the cuts after the fashion of New Zealand tattooing.

I marked several fish at Galway, in a great variety of manners. On to the fin of one I fastened for fun a fourpenny piece with a hole in it. The net-fishermen who were assisting my operations did not seem to like this waste of money. " A sovereign," said I, a few minutes after I had let this moneyed fish into the river-" a sovereign reward for any man who catches that fish next season in the nets, and brings him to Mr. Miller."

"Bedad, sir," said one of the men, "we shall never see the money, though we may the fish again."

"Why not, Turk?" said I.

"Sure, he is an Irish fish that's got money, and 
310 THE SUCCESS OR OTHERWISE OF SALMON FISHERIES.

he's off to the public-house and spent it by this time, sir. You'll never see that coin again; it's gone for whiskey long ago, sir."

I would now venture to say something upon the reasons which cause a salmon-fishery to be productive or non-productive. It stands to reason that if seeds be not placed in the ground the farmer will not be able to reap any crop ; if the game preserver does not preserve the eggs of the breeding birds, he will have no pheasants nor partridges to shoot; so too, if the water-farmer does not protect the eggs of his water-game, he will have no fish when the harvest time comes. These are facts which are comprehensible to everybody.

And what, after all, is the talisman of success in the management of the Galway fishery? A maxim that may be applied to all fisheries. It is simply leaving the fish to follow their own instinct, assisting them to surmount obstructions, keeping pollutions out of the river, and instituting a strict system of supervision over the parent fish during spawning-time.

Having examined the salmon and their habits in the adult stage, I was anxious to examine the actual spawning-grounds. I gladly, therefore, accepted the kind invitation of a gentleman who knows every inch of the ground to examine the spawning-grounds of the Galway fishery. 
The Galway fishery is especially fed from an immense catchment basin, of which Lough Corrib and Lough Mask form the lowest level. The fish run from the sea into Corrib; they cannot as yet be certain always of getting into Mask; they wait in shoals at the mouth of the river at Galway, and when they get a smell of the mountain-water coming down, up they go, ascending in some instances (as about Maam) almost to the tops of the mountains.

In order to visit the upper waters, following the route of the salmon, we passed the whole length of Corrib, a magnificent lake, about twenty miles in length, and from two to ten in width, filled with the purest water from a limestone formation.

A steamer runs from Galway to Cong, a small village which is situated at the head of Corrib and between that and Mask. I must, therefore, say something of Corrib.

It was an excessively hot morning when we started, the temperature of the air being $81^{\circ}$, and the temperature of the water $70^{\circ}$; the water, moreover, was so excessively clear that we could see the bottom of the lake almost as clearly as one can see the stones of a pavement from the top of an omnibus. The passage is marked out through the lake by means of rocks covered with whitewash. As we passed along the lake the awful rocks below us had what I should 
imagine would be the appearance of a range of mountains seen from a balloon, while huge boulders rose here and there, the tops of which form the guideposts to the steamer. I could also see at the bottom of the lake gigantic masses of stone as big, almost, as an ordinary London house; and by the side of them large plateaus of long flat slabs, between which we could look down upon yawning cracks wide and deep like the crevasses of the Mer de Glace at the foot of Mont Blanc.

On the steamer we had the good fortune of meeting a gentleman who owned a fine estate by the side of the lake, and also with Mr. D'Arcy, son of the worthy and energetic rector of the town of Galway. Mr. D'Arcy informed me that in the lake were no less than 365 islands; he himself (being the owner of several of them) inhabits one which is situated just opposite the town of Oughterard. He informed me that, long long ago, several families, possibly Anglo-Normans, came over to Galway (hence it is sometimes called the City of the Tribes), and carried on large shipping business with Spain ; the descendants of these early settlers still remain, and the names of Lynch, D'Arcy, Bodkin, Burke, and Skerrit are still common. These ancient merchants, having so much dealing with Spain, naturally, in course of time, adopted somewhat of the Spanish manners and habits; and, as the visitor walks about 
Galway, he may observe a number of ancient houses, with courtyards surrounded with high walls, large porticoes, ornamented with stone-work, and guarded with heavy gates, reminding one much of a Spanish town. The merchant-princes of Galway, who inhabited these houses now so changed in their appearance, were not, however, allowed to live in peace, for the native Irish chieftains persecuted them to an extraordinary degree. So terrible, indeed, was the persecution by the O'Flaherties of the Galway inhabitants, that, as Mr. D'Arcy informed me, in former times a prayer was used in the Litany - "From the ferocious O'Flaherties, good Lord deliver us." Mr. D'Arcy pointed out to me a gentleman's house on the borders of Lough Corrib, which was still inhabited by one of the descendants of these áncient Irish clieftains.

As we passed along we observed many boats on the lake, laden with turf, and this naturally led us to discuss the geological origin of bogs. Mr. D'Arcy informed me that not very long ago, when the men were digging in one of the bogs near Oughterard, they found a most curious object, viz., a keg of fossil butter. He told me, moreover, that it belonged to Mr. O'Flaherty, whose house we saw in the distance. Some days afterwards I called upon this gentleman, and his amiable lady was kind enough to show me this curiosity. It consists of a large mass of material, very much the size and shape 
of an ordinary butter-tub. I found it to consist of a substance something between common lard and common white soap, giving, moreover, a soap-like touch to the finger. The local story is that this specimen is a keg of butter, which from some unknown and inexplicable cause or other has become fossil. Immediately on examining it I fancied I saw through the whole case, and concluded that it was exactly an analngous case to that described long since under the head of Fossil Pork by my Father. He never published anything about it, though he frequently mentioned it in his lectures at Oxford, of which, I am happy to say, I still possess my own copious notes. In the year 1825 the Rev. Mr. Fazakerley, curate of Swilley, near Bampton, Devon, brought the case forward, and the following is the substance of the Dean's notes upon this Fossil Pork :-

"About fifty years ago, in digging out a pond at Crewys Morchard, near South Molton, the workmen found a great accumulation of the bodies of pigs that had died of the measles.

"Cattle that die from such diseases are usually thrown into a pit together; and, if buried in wet ground, the muscular and all other soft parts of their bodies are turned to adipocere, which is of the same chemical nature as spermaceti. Still more readily does the lard and flesh of hogs undergo this change if buried in 
contact with water. Thus a friend of mine found a pig floating on the mud of the Avon below Clifton, completely converted into adipocere. Dr. Beddowes once kept a dead cow in the Cherwell, near Magdalen College, till it was converted into adipocere; and in very wet churchyards buman bodies are often thus preserved for centuries in the state of mummies." *

When searching for the body of the great John Hunter (vide antea), I discovered, among other most curious facts relative to the decomposition of the human body, several examples of this wax-like substance, adipocere. The keg of fossil butter from the bogs of Ireland was exactly like what I saw in St. Martin's church vaults: I can only account for its presence in the bog by imagining that at some distant time a pig or a cow had been buried in the bog by some peasant, in future times to be dug up under the form of "fossil butter." My theory, however, as to the nature of this fossil butter does not meet with universal approval, and it is possible the material shown me by Mr. O'Flaherty may be butter after all. I shall be glad of further information. (See Appendix.)

On our arrival at Cong we were welcomed by Jemmy Burke, the head water-bailiff of that district of the fishery, and having time to spare, visited the ruins of

* I have examined a case;--in twelre years the whole body had been converted into adipocere. 
Cong Abbey, and made a sketch of the curious cross upon the grave of Roderick O'Connor, the last king of Ireland, who died A.D. 1198; the inscription is wellnigh worn out, and it is much to be regretted that some of the authorities of the place do not have it renewed, as the words, "O rare Ben Jonson," were cut over his grave in Westminster Abbey at the kind instance of the illustrious philosopher.

Strange to say, the monastery of Cong is said to owe its ruin to the angling propensities of the monks, for the story goes that "the proprietor of the place, one Richard Bourke, and his wife, were invited to dine at the monastery. The lady observed that the friars had their nets and fishing-rods so contrived that the butt of the rod passed from the river outside through a chink in the wall to the table at which they dined, and that on the top of the rod was placed a small bell which rung whenever the bait was taken or the net was struck by a fish in the river. For this reason, combined with other beauties and useful contrivances belonging to the place the lady vowed she would be possessed of it; and she never ceased till she got her husband to banish the whole fraternity. They were said to be 700 in number when banished."

The next morning we examined the celebrated Cong Pass, a canal cut through the spur of the mountain 
which separates Lough Mask from Lough Corrib, and upon which my friend, Mr. T. Ashworth, has spent much thought and capital in order to convert Mask and its tributaries into a vast area of spawning-ground (hitherto unoccupied) available for his salmon. Whether the laudable efforts he has made, and is still making, will ever succeed, time alone will prove. Spawning-fish have been seen to ascend. The uppermost mile and a half of the pass, the whole length of which I examined with Jemmy Burke, the water-bailiff, took us over as desolate a country as ever my friend Mr. Tristram crossed in his adventurous journey in the Holy Land.

As we approached the water-gates leading into Lough Mask, standing alone in utter solitude, like the Pyramid of Cheops amidst the sands of an ancient ocean long since disappeared-for this is the true history of the deserts of Egypt-I fancied I saw something moving about on the gangway of the Lough gates. I pointed it out to Burke, but neither of us could make out what it really was. As we got nearer we perceived that it was a man's head with a cap on-but who and what could he be? On approaching the gates not a living creature could be seen in the fearful solitude of the place, and we were rather puzzled. At last, from behind a huge stone, there crept out a human figure-such an object! all rags, filth, long unshorn hair, semi-clothed person, 
and a face not otherwise unintelligent, but still marked with that peculiar expression which at once denotes a madman. I confess I was not over-comfortable at the appearance of this man, and I endeavoured to recall to mind the physiological symptoms as marked in the countenance of a person possessed by amentia, dementia, monomania, general paralysis, \&c., as learnt during my medical studies. A glance, however, showed me that this poor fellow was harmless, that he was, in fact, $\delta a$ -

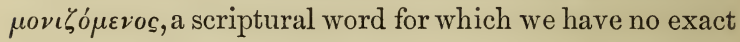
equivalent term in the English language. I advanced (I confess hardly without trembling) towards the poor fellow, and cffered him the whiskey flask, and followed it up by a parcel of sandwiches which I happened to have in my pocket. For a moment the evil spirit left him, and a beautiful smile came over his face as he snatched what I proffered him from my hand, and eagerly devoured it. His appetite satisfied, I atternpted to enter into conversation: but the mind had fled, leaving only a human form in the most abject state of misery and desolation it is possible to conceive, the only answer to my questions being hideous grins and incomprehensible gesticulations. We moved gently away, but the poor fellow followed us at a short distance, gesticulating frightfully, and talking to himself; - both Jemmy Burke and I were prepared to defend ourselves in case of his attempting to stone us, which we 
rather expected. At last the poor madman got tired, and, sitting on a rock, shouted and cried till we were a good way from him. Jemmy then told me that the unfortunate man was known in the neighbourhood; that he lived during the summer months wandering about alone amid the desolate regions of the hills and waste land around the Cong Pass; in the daytime he basked in the sun, in the nignt he betook himself to some hole or overhanging rock, in which he scraped together a few leaves and heather, and there made his bed. $\mathrm{He}$ obtained his food by occasional scraps which the poor people-all credit to them-gave him. The desolate and barren scene, the intense silence, the vast expanse of Lough Corrib at our feet, and the poor madman raving behind us, made an impression on my mind never to be obliterated, and realised the incidents which must have taken place on that remarkable occasion when, by the immediate operation of Divine power, the "unclean spirit" was in a moment driven out from the man, "who always, day and night, was in the mountains, and in the tombs, crying and cutting himself with stones."

The Cong Pass examined, we took a car for Hollymount Farm, occupied by Mr. Maxwell, where there is a little stream proceeding from a spring which empties itself into the Ballynrobe river, which river runs direct into Lough Mask. 
It is at this locality that the experiment of hatching salmon by artificial means has been instituted by $\mathrm{Mr}$. Ashworth, with the idea that no chance should be thrown away of utilising, even in spite of the difficulties of the Cong Pass, the now barren 22,000 acres of Lough Mask. One of the chief objects of our journey was to examine how matters were going on with the young fish.

In the spring of 1863 an artificial watercourse, eighty yards long and four feet wide, was cut parallel to the natural stream, and a hatchway placed at both ends to regulate the flow of water, which empties itself into a pond about twenty by thirty yards in extent. The bottom of this watercourse being covered with gravel, upwards of 300,000 impregnated eggs were brought fourteen miles from Clare, Galway, and deposited on the gravel. It became my task to ascertain, if possible, what the practical result of this experiment had been. As we walked towards the pond Mr. Maxwell informed me that "there was not an egg put alive into the brook but that had come out a fish, and there were still a great number of fish in the pond, although a few had escaped into the ditch leading down into the river." As we walked along this ditch I observed an enormous number, not of salmon, but of "tittlebrats," which are also known here as "Jack Sharps" and "Lebians," and every here and there, few and far between, a young salmon or two. 
Arriving at the pond, I requested my companion not to go near till I had crept upon hands and knees and examined the fish before they had been disturbed or frightened. From the account I had heard from Mr. Maxwell, I had expected to see a very large number of young fish swimming about in the pond. I was therefore greatly disappointed to observe very few fish indeed in any part of it. It must be remembered that 300,000 eggs had been placed down; and even supposing we knock off half this number for natural losses and death, there ought to be 150,000 fish remaining.

I was positively certain (my eye from considerable practice being accustomed to arrive pretty accurately at the number of young fish in a mass), that from what I saw - and I had both my eyes as wide open as the eyelids would permit-there were not above a thousand or two of young salmon in the pond, if so many. What, then, had become of them? Enemies of some kind had evidently devoured them. I asked Mr. Maxwell if he had ever found any dead fish in the pond, and he said, "Very seldom indeed, but he had often observed fish swimming about with a white speck at the end of the tail." Although it was a very bright clear day, nothing could be seen moving in the pond but a few little salmon.

Being determined, however, to find out what the enemies were that destroyed these fish, I fastened a SER. III.-VOL. II. 
piece of muslin on to the end of the landing-net, and drew it along sharply under the edge of the grass and weeds which overhung the margins of the pond. While doing this I ascertained at once that the bottom of the pond was covered with mud, a fact in itself militating against the well-being of young salmon. In this mud my net showed in a few seconds that there existed hordes of hungry-minded, bloodthirsty ogres, which would devour the young salmon like wolves let loose on a flock of lambs. As I took my net out of the water, I found that the result of my haul was a number of great black water-beetles, principally Dytiscus marginalis, of which Mr. Wood writes in his "Natural History," vol. iii. page 464: "The larva of the Dytiscus is a terribly ferocious creature both in aspect and character. It inhabits the waters, and is a very hyæna in the terrible grasp and power of the jaws. The perfect insect is quite as voracious, and, when a number are kept in a single vessel, they are sure to attack and kill each other. No one who cares for the animated inhabitants of his aquarium should permit a Dytiscus to be placed among them, as a fox makes no more havoc in a chicken-roost than a Dytiscus in an aquarium. The courage and ferocity of the creature are so great that it will attack insects much larger than itself, and not even fish can escape the jaws of this insatiable devourer."

I called to my friend, who was waiting the result of my investigations. 
"There," said I, pointing to the contents of my net, "are the horrid rascals that have been doing you hundreds of pounds' worth of mischief this last season. The fish which you hatched with so much care and expense have served only one purpose, viz., to feed these horrid blackbeetles; and a nice time they have of itplenty to eat, and nothing to do! No wonder MIr. Maxwell has seen several fish with white marks on their tails-they are the wounds left by their cuirass-cased enemies, from which they have been fortunate enough to have escaped by speed of fin. And no wonder, again, that he never saw a dead fish: there are too many hungry beetles in this pond ever to allow such a precious morsel as a dead fish to escape their voracious maws."

"Can you show me that this is clearly the fact?" said my friend.

At that moment a huge black Dytiscus came swimming past with all steam up, and his oars going like those of the winner of a skiff-race, for this old " soldier" evidently was aware, from the mud and disturbance that was going on in the pond, that something was wrong, and he must look out for himself at once. I caught him with the net as he passed by, and sent a boy back for a preparation bottle, a number of which I always carry with me. I put my water-hyæna into a bottle. "Now," said I, "if my theory is correct, that fellow- 
although he is in captivity, and a prisoner-will fly at a little salmon put in with him, just as surely as a terrier will fly at a fox when he is run to earth by the hounds." So I caught a little salmon and put him into the bottle.

Spying him from below, the beetle rose straight up at the unfortunate little fish, making direct for him-with that peculiar savage determined rush that one sees when a bulldog is slipped at his enemy. In an instant the beetle rose above the salmon, and then pouncing down upon him like a hawk upon an unsuspecting lark, dug its tremendous, scythe-like, horny jaws right into the back of the poor little fish. The little salmona plucky little fellow-fought hard for his life, and swam round and round, up and down, hither and thither, making every effort to escape this terrible murderer; but it was no use, he could not free himself from his grip; and while the poor little wretch was giving the few last flutterings of his tail, the water-beetle proceeded coolly to pick out his left eye, and to devour it at once with evident gusto.

I must say I was much amused to see my friend's countenance while the performance between the salmon and the beetle was going on. First a flush of surprise stole across his face; this gradually warmed up into a glow of, I may say, angry disappointment, and he and I, joining hands, danced round the bottle, which I placerl 
on the top of a gate-post, in order to work off our emotions, shaking our fists and vowing vengeance against the whole race of blackbeetles, and particularly the happy family of them that had taken up their quarters in the Hollymount pond, and had eaten up the 200,000 innocent young fish.

We therefore held a drum-head court-martial, and condemned to immediate execution the murderer which we had in close custody in the bottle. It was suggested that a wee drop of genuine potheen whiskey would do his digestion good after the capital fish dinner he had just taken. While, therefore, our friend was still engaged in devouring the murdered salmon, we gradually poured the water, which formed his dining room, out of the bottle, and then gradually filled it up with a dose of very strong whiskey. As the whiskey was gradually added to the water, the beetle became uncomfortable, but still he did not let go the body of his victim. "More, more!" cried my friend, "give him more whiskey; he can't live in that, the villain!" So we filled up the bottle to the top, and then it was the beetle's turn to dance and cry "peccavi;" for as the whiskey got into his head, and he was obliged to swallow it nolens volens, he flung himself madly about the bottle in all directions, and at last, finding himself getting faint, he "turned up the white of his eyes" and sank down to the bottom alongside the body of his murdered 
victim. This fellow is now a famous beetle, and has been nicely "set up" in a preparation bottle in company with his victim. All we want is an heroic poem, a match to Homer's Baтрахонvолахia, "Battle of the Frogs and Mice," describing in equally glowing colours the battle of the "Beetles and the Salmon."

What, then, was to be done to save the lives of the few little salmon that still remained in the pond? Why, let them go, of course. We therefore opened the hatch of the pond, and away they went in shoals-tails foremost, mind-glad enough, doubtless, to get out of their prison-house. For it would, indeed, have not only been impolitic, but even cruel, to allow these poor little wretches to remain in the pond to be devoured by the blackbeetles.

As the water receded and the pond became dry, I waded into the mud to assist a few little fish that had got stuck fast among the weeds. In so doing I discovered that this mud was not only a perfect hotbed of these carnivorous blackbeetles, but that every here and there jumped up a specimen of a kind of fresh-water "great sea-snake," viz., the larva of the dragon-fly, a terrible foe to these little salmon. So many ard various, indeed, were their enemies that I much wonder that any of the 300,000 little fish ever survived at all. We had our vengeance on these water vermin by letting the water entirely off from the pond and allowing them 
to meet the fate they deserved, viz. swim, and live if they could, on dry land.

What, then, is the moral of this sad story of the murdered immocents? It is simply this, that ponds, as a rule, are very bad situations in which to rear young salmon. In the first place, a young salmon is not naturally a pond fish. If we wish to see them in their natural habit, we search for them in rapid-running shallows. Why, therefore, put them in a pond where they have to encounter the attacks of water-beetles and other creatures which can never reach them in their natural growing streams! I assure my friends that I think the pond system is a mistake, and that they had much better transport their young fish (when the umbilical bag is nearly absorbed) into shallow streams and rivulets where the fish are found naturally, for, depend upon it, these young creatures know better what is good for them than we do, and they will always do better in shallow running streams than in ponds.

We had more of the breeding-ground of the Galway fishery to examine, so taking a car, we started en route for Maam. However much travellers are indebted to the Ordnance maps of Ireland for information as regards localities, they must not judge of the sizes of places by the size of the letters which denote their position. Thus, for instance, I find that the word Ballynahinch takes up 
exactly an inch on the map, and this is equivalent by the scale to four statute miles. Again, the word Maam is half an inch long. If, therefore, the places themselves bore any proportion to their names on the map, both Ballynahinch and Maam ought to be very large places; whereas at Ballynahinch I could not discover even a village, and Maam turned out to be simply one house and a wilderness. I was sitting writing at my notes on the car when the driver pulled up at a little bit of a public-house by the roadside. I did not even attempt to get out of the car, thinking we had merely stopped for a few minutes to give the horse some water. Much was my surprise, therefore, when my friend said, "Jump down; this is Maam, and we must stay here all night; so make yourself contented!"

A friend of mine has lately taken a house in the country, so far from civilisation that he tells me he is obliged to give even his chimneysweep a bed. Maam is even worse than this, for my friend's bailiff had to send forty miles for a pair of boots; and the landlord, having no bread or whiskey in the house on our arrival, was obliged to send a man and dog-cart twelve miles to the baker's, and twelve miles home again, to get supplies for us.

There is in my mind a standard rule, viz., that no place on the earth is so stupid or so desolate as not to afford information or instruction of some sort or kind, 
if one only knows how to hunt about for it. It has been said that there is but one rule without an exception, and that is, " a man must be present while he is being shaved." Maam is no exception to my standard rule, so I set to work to pick up what I could of its history, products, and local traditions.

Though almost the Ultima Thule of civilisation, Maam has its charms and its history; for was it not at Maam that the Lord-Lieutenant himself, being refused a night's lodging at " the hotel," was obliged to go on to Cong at once with tired horses? Was it not at Maam that the murder of a poor woman was committed not very long ago? The poor creature and her husband had made a little money in Australia, but such was the amor patrice in her breast that she returned all the way from that distant land to this winter-clad and desolate Maam. A few weeks after her arrival a brute of a fellow knocked the poor creature on the head as she was sitting alone in her cottage. I regret to say the rascal escaped justice, witnesses being unable or rather unwilling to appear against him. And is not Maam a pocket Switzerland, whose glorious mountain tops pour down crystal streams, the nursery and breeding-ground of salmon-fry innumerable?

How it is that salmon understand that, in order to bring their eggs into young fish, a shallow running stream is necessary, I know not; anyhow, they will, 
if they can, choose mountain streams in which to deposit their eggs. When I examined these streams I found them literally swarming with young fish, showing that the water bailiff, Martin Walsh, had done his duty properly towards his master during the last winter, even though he had to remain out night after night, behind some turf-bank, watching for poachers. He tells me that in the winter time the streamlets are quite black with spawning salmon, and, judging from the remains of numerous salmon nests which I saw, I can easily believe this to be the case. The water in these streams is sometimes excessively cold, and, doubtless, the salmon are sometimes prevented from spawning by tile low temperature.

Mr. John Miller informs me that frost hinders the spawning fish in a peculiar way.

The frost puts the salmon off their beds. The fish, if hindered from the operation-from getting to the nest - too long, will deposit their eggs in a solid mass, like a bunch of grapes, when, of course, they perish. I do not believe that frost is very injurious to the eggs themselves, if they have been properly placed in the nest. The Australian experiments have shown that eggs can be preserved in ice* for a much longer period than is likely to take place in their natural streams.

* That ice will preserve animal substances for a very long succession of years without decay, if only these sulustances be 
The salmon at Maam, I am convinced, from what I saw, sometimes make a mistake in building their nests too high up the mountain streams, for if there is too much water at spawning time, the fish are induced to go so high that their eggs are left dry as the water recedes. We must, I think, put up some sign-posts to inform the fish of this danger to which their eggs are liable, only that I fear they would not be able to read the notices unless they were written in Irish characters; and where is the man to be found who can write Jrish?

The air in the valleys between the Maam mountains is, so to speak, ponded air, being, when I was there, as unruffled as a mill-pond on a hot July day.

"There ought to be some fairies about here," said I to the guide.

not exposed to the air, has been exemplified by a story an Oxford friend has told me. When wandering this summer along the bottom of the Glacier des Boissons, in Switzerland, they discorered a portion of human hair and a bit of a man's dress sticking among the ice. He and the guide set to work and examined the ice all around; and shortly they discovered a human thigh buried in the ice; upon knocking this out of the ice the flesh was seen to be in a perfect state of preservation, but exposure to the air soon caused it to decay. They also found a leathern purse, with sixteen francs in it, the money bearing the portrait and date of the first Napoleon. These were the relics of an expedition which was lost some forty years ago. An avalanche destroyed nearly the whole party, whose remains, entombed in ice, have in this space of time been carried from the top to the bottom of the glacier. 
"Fairies! yes, your honour. I have never seen one myself, though I have been always in dread of them. My father saw one once as he was coming home at night among the mountains. The fairy stood before him in the middle of the road; the horse he was riding saw it, and stood up on his hind legs, and, shying, passed on one side, and galloped straight home. My father was in bed for two months, and at last a priest came and made a gospel for him, and he got well. The fairies are like little boys, not badly dressed. They come down at night from the hills and play. They never speak to anybody, and run away directly they are seen. I think that the fairies are as much in dread of the men as the men are of the fairies; but anybody who sees them is sure to have bad luck soon."

It is very curious how this idea of fairies and witches is still prevalent, even in districts not far from London. A clergyman, whom I met when staying at the Bishop of Oxford's in Sussex, tells me that some of his parishioners, in a village underneath the lone and bleak Sussex downs, believe in witches even now, and that if a horse when taken up in a morning from a field be unable to do a day's work, they say the fairies have been riding him about all night. The origin of this tradition is, I believe, that in former times a good deal of smuggling went on at night, and the smugglers used to take the farmers' horses out of the field, and use them in the 
night. The existence of fairies was a very ready mode of accounting for horses being fatigued. The manes, again, of many of the semi-wild colts turned out in the New Forest are often found knotted and matted together in a complicated way, and the story is that their manes have been twisted together by the little fairies in order to enable them to climb up on the ponies. These matted manes are known, I believe, by the name of "the fairies' bridle."

Between eleven and twelve o'clock of the night we spent at Maam, I took a solitary walk to see if I could come across some of these mountain fairies. It was a most lovely night with a beautiful moon, and the lake as still as glass.

The moon,

Full-orb'd and breaking through the scattered clouds, Showed her broad visage in the crimson east.

I looked everywhere about, but could see no fairies -it was possibly the least bit too cold for them, for I know they love the warmth ; however, on turning a corner I saw a curious sight. In an angle of the lake, underneath the bush, something or other was moving round in the water very fast, describing circles of about a foot in diameter. There were, I suppose, twenty or thirty of these circles, which crossed and recrossed each other at various intervals. The moon caused these circles to appear like rings of silver, and they were 
certainly very mysterious and beautiful in the calm stillness of the night. I tried very hard to creep up close to these circles, as I conceived it possible there might be water fairies as well as land fairies, and that a party of them were out at play. The shadow of the bridge falling on the very spot, however, prevented my seeing anything whatever. My belief, however, is, on considering the matter carefully, that the circles were simply caused, not by fairies, but by perch at play, swimming round and round with their mouths on the top of the water, either for food, or else for mere sp^rt, for I don't see why fish should not have their "little games" like every other living thing. A lively imagination might easily have transformed these creatures into fairies " at play:" if they really were fairies they must have been Naiades, or water fairies.

If space would allow, I should have liked to have written much more about the salmon, oysters, and other matters that came under my notice in Ireland. I will, however, with the reader's permission, content myself with placing on record but one or two more facts which I learnt.on my journey.

At and about the head of Lough Corrib are found specimens of the large fresh-water mussels. The headquarters of these seem to be Oughterard. On our arrival at this pretty little place we were greeted with 
volleys of "Yer honer's welcome!" "Long life to yer honer!" from one of the strangest characters I ever beheld-Jemmy the Pearl-catcher.

Jemmy, I observed, wore a shoe on one foot, and no shoe on the other. He told us that "one foot was a gentleman and the other a blackguard; one foot was the Catholic foot, and the other a Protestant foot." The Catholic foot was the one that had the shoe on, and enjoyed the proper privileges of a foot, whereas they were denied to the Protestant foot. Jemmy's proper occupation is a buyer of pigs, as he is supposed to be one of the best judges of pigs in the country. One day, when overcome by undue potations after a bargain in re pigs, somebody tried to persuade him to become a "Jumper," that is, to turn his faith in matters of religion, and he was so far persuaded that he was induced to place one foot inside a building devoted to the Protestant persuasion. He was so angry with this foot for becoming a "Jumper" that he rowed vengeance upon it; he therefore has punished it ever since by never allowing it to wear a shoe or stocking, and by putting it out of the bedclothes at night, " in order to allow it to perish." We expostulated with Jemmy upon thus torturing this poor Protestant foot, and gave him some money to buy a shoe and stocking for it, in order that it might have equal advantages with its brother foot of the opposite persuasion; but I much 
fear that the foot has not yet benefited by our good wishes, for on receiving the money Jemmy was observed to look into the door of the shoemaker's shop, but to go into the door of the public-house, from which he shortly emerged in such a state that neither of his feet, either Protestant or Catholic, could carry him straight along the street.

Jemmy gets his living by collecting pearls from the mussels which abound at and about the town of Oughterard. He is like the "medicine man" anong the Red Indians, very mysterious in his movements when he goes out to look for pearls, his principal enemies being the small boys, who, could they find out where Jemmy's mussel-preserves were, would come and poach upon what he considers his own rightful property, and, taking his pearls, would injure his business in the pearl trade. He told me that he knew without opening it, when a mussel had a pearl in her, because "she sits upright with her mouth in the mud, and her back is crooked, that is, it is corrugated like a cow's horn," a fact which he demonstrated to me from a number of mussels which he had in the basket. He opened one of these crooked-backed mussels, and sure enough Jemmy was right in his diagnosis, for there was a pearl in it a little larger than a turnip seed. He then mysteriously produced from the lining of his very old shabby hat, a very dirty bit of rag, and in this rag were two of 
the most beautiful pearls I ever beheld, which, if properly set, would form ornaments fit for the locket of any lady of her Gracious Majesty Queen Victoria's court. Such pearls as these Jemmy said he did not get every day. It was a very rare piece of luck to find them, and they were generally found in mussels which lived in such deep water at the edge of Lough Corrib, that, having no boat or dredging apparatus, he is obliged to go into the water, swim over to the place where the pearls are, and then keep on diving down for them like a cormorant fishing among a shoal of herrings. Sometimes poor Jemmy has a run of bad luck. Last winter he was nearly starving, and he did not know what to do, for none of the mussels he opened had any pearls in them, and nobody wanted him to buy any pigs. When matters were at their worst, he saw four mussels with their noses out in the mud, a sort of family group; he went into the water and brought them out. When he opened them, to his great delight, one of them had two large pearls in it: he sold them at once, and they fetched him $2 l$. $8 s$. No wonder, therefore, that Jemmy does not like the boys to know where his favourite hunting grounds for mussels are situated.

Jemmy haunted us wherever we went, even up to the last minute of departure; and as the car drove off, he held up his Protestant foot and waved it about in triumph in the air, as an elegant mode of wishing us a SER. III.-VOL. II. 
last adieu to Oughterard. Though this poor pearlcatching Jemmy is a dirty, ragged, and, I fear, somewhat intemperate individual, yet, after all, he seems to be a good sort of fellow, and deserves to be encouraged in his pearl-finding operations by salmon-fishers as they pass through Oughterard on their way to the far-famed salmon streams of Ballynahinch.

When we arrived at Ballynahinch, we were most hospitably received at Ballynahinch Castle, by our triend, Mr. Robinson. It was here that the celebrated Colonel Martin lived,* who boasted that his park gates were thirty miles from his door, and who, or else one of the family, I believe, was the gentleman that brought a motion into the House of Commons : motion made and question put, "That every quart pot should hold a quart." It was, too, I fancy, this same Colonel Martin who was called "Cruelty Martin," a most undeserved name, given him because he, being a most humane man, was one of the most energetic promoters of the Society for Prevention of Cruelty to Animals. Feeding in front of the house I met, face to face, a four-footed beast; on seeing him, I took of my hat and made him a low bow. "Little, my poor little hungry beast," said I, " do you know the very ancient and noble family of "Bos' that you represent! for most assuredly you carry the family likeness strongly impressed on your face and on the

* Westward, where Dick Martin rules The houseless wilds of Connemara.-Moore. 
fashion of your horns. You must, indeed, be a direct descendant of Bos longifrons, now so long extinct in England. Long, long ago, the ancient Britons herded large numbers of your ancestors, and many a noble bull of your family was pole-axed at the sacrificial altars of the officers of the Roman legions, when quartered on the high grounds of England; for do not the very skulls yet remain, with the mark of the Roman axe impressed on the forehead by the Roman priest? Long may you live to enjoy the luxuriant pastures of Ballynahinch ! but if your owner does not, on your decease, give me your head, to hang up in my museum by the side of the semi-fossil skull of one of your ancestors, I shall never forgive him."

I learnt, among many other things, from my friend $\mathrm{Mr}$. Robinson, a very remarkable fact relative to two curious diseases that attack the cattle which feed on the hills at and about Ballynahinch. These maladies are locally called the "Pine" and the "Cripple;" and although we may often foolishly laugh at popular names for diseases, whether of man or beast, yet it often happens that the Vox Populi gives one really a more clear and distinct notion of the nature of the disease than the $V o x$ Medici-though it may be heresy on my part to be of this opinion.

When staying at a village in Yorkshire, I was attracted to a pig-stye by the agonising cries of a poor 
pig. I asked the man, who was digging potatoes in the garden, what was the matter. He told me that he was "pining the pig," a humane process, which I found consisted in giving the poor beast nothing whatever to eat or drink for some eight-and-forty hours previous to his being conducted to the pork-butcher's private apartments. I asked the man how he would like to be pined. He said he should not care about it, particularly if it was in Christmas-week; but if the pig was pined he would be saved so much trouble when he came to dress the animal's carcass. Alas! for the laziness of mankind.

The "pine" in the Irish cattle is not produced by the cruelty of their masters, but from another cause; beasts living near the sea-shore eat the sea-weed, and also the grass on the mountains; this is said to make them fall away to perfect scarecrows, or, as a very thin man was once defined, to become in such condition that he was "fit to fight the living skeleton."

' The "cripple," on the contrary, occurs in cattle which are fed on the mountains away from the sea ; the peculiarity of their disease consists in great enlargement and swelling of the joints, which crack when pressed by the finger; the bones themselves, however, do not seem to be in any way affected, except in old-standing cases. This cripple disease occurs in weather when damp misty days are succeeded by cold winds, and always 
on the hill-side. I have not had an opportunity of examining a "cripple," but I am nearly sure that this disease must be nothing more nor less than chronic rheumatism of the synovial or lining membrane of the joints.

It is curious to remark how a remedy for these two diseases is naturally provided, and how a little knowledge in this matter is a most useful, instead of being a most dangerous thing. The cripples are transferred to the sea-side, where, in an amazingly short time, the swelling of the joints disappears, and the beast recovers its condition. I fancy that this is to be accounted for by the quantity of iodine and other marine salt which the creature takes into its system when eating the seaweed. The cattle affected with the pine are, on the contrary, transferred to the mountains, where, owing, I suppose, to their getting grass which contains the ingredients in which the seaweed is deficient, they speedily recover.

I feel it is now time that I concluded these notes upon what came under my observation during my visit to Ireland. I have endeavoured in all I have written simply to record facts and relate anecdotes, which may if possible be applied to practice for the benefit of the public in general.

We are, depend upon it, getting to a period when natural history is assuming a new and very important 
feature, viz., its application to practice, especially as regards the great questions of the fisheries, both sea and river. It takes as much time to examine the habits of a tittlebat as it does to examine the habits of a salmon, though one is useful to mankind, the other perfectly useless; and it takes as much time to write a label for a hippopotamus as it does for a mouse. Why, therefore, should not our friends residing in the country pay as much attention as possible to the habits of really useful creatures? For we little know what secrets Nature may have in her innermost laboratory, which she may possibly disclose to those who patiently and humbly ask her for information.

The true secret of happiness is constant employment ; and what can be more delightful than the examination of the wondrous works of nature. What, again, more in accordance with the social nature of man than friendly converse and argument with one's fellow creatures on the high change of mental ideas, remembering always the motto that ought to be emblazoned on our standard :-

" PEACE AND GOOD WILL TOWARDS MLN." 


\section{A P PE N D I .}

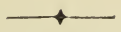

EXHIBITION OF VERMIN TRAPS BY THE ROYAL SOCIETY FOR THE PREVENTION UF CRUELTY TO ANIMALS.

Is July $186 \pm$ an exhibition of rermin traps took place at the Royal Horticultural Gardens, South Kensington, under the following circumstances:-

"A benevolent lady, having induced sereral noblemen and country gentlemen to subscribe an amount, placed the same at the disposal of the Royal Society for the Prevention of Cruelty to Animals. The committee have, therefore, offered a prize of $50 l$. for a trap which shall serve the purposes of game preservers without inflicting torture. They have unbounded pleasure in announcing that this project has receired the support of many of the leading sportsmen of the country, and rejoice to learn that many humane game preservers have already discontinued the use of the old steel trap, and that others are now awakening to its barbarity."

On the appointed day upwards of 100 traps were sent in for competition. I was honoured by an invitation of the committee of the Society to assist in examining these traps, and I shall now tell my readers something about them. Simple as may seem the problem of entrapping a wild animal, yet the actual practice of so doing is evidently difficult, for a more ingenious number of contrivances by means of which the mind of man is matched against the instinct 
of the brute I never before examined. There are some traps large enough to catch, not the vermin, but the keeper who looks after them;* some again are so small, that even a mouse might have a chance of escape-some so complicated, that it requires ten minutes' examination for a human being to understand their action-some so simple, that one is inclined to say, "How is it that was never thought of before?"- -some so difficult to set off, that one has to tug at the trigger with an iron wire to make it act; and some so delicately contrived that they go off almost if one only looks at them. Some again are devised to crush-some to holdsome to transfix with sharp-pointed spikes-some to guillotine in the most approved French style--some to "pole-axe" - some not only to first entrap the animal, but also to kill him when he is entrapped-some which catch the animal before he has hardly entered the portal of the trap-some which require two animals to make the trap act, one to go in and the other to pull the spring-some so very trap-like and so decidedly dangerous-looking, that I almost expected to see a notice at their portals, "Pay here, one shilling: no return tickets given."

When we first began our sittings, I stated to the committee that I thought we should find that the oldest of all possible traps, the device used by all savages, viz., the pitfall- would be the idea upon which many of the competitors would found the conformation of their traps; and this turned out to be the case, for the principle of the pitfall we found had been adopted and diversified in the most wonderful manner. Among the pitfalls I would mention a square zinc box with a double lid, each lid being so beautifully balanced that the moment the animal places his

* A gentleman who had been subject to the nocturnai visitation of thieves in his orchards, wishing to preserve his property without endangering any one's life, procured a model of a leg, which he placed one evening in a steel trap in his garden, and next morning sent the crier round the town to announce that "the owner of the leg left in Mr. Johnson's ground last night, might receive it upon application." He was never robbed again. 
foot upon one of them, it gives way, precipitating him down into the pit, and instantly rises again for the next comer. This trap can be so made as to catch anything, from a man to a blackbeetle. In this trap the inventor told us he had at one haul captured "a cat, a stoat, and a toad ;" at another time "a jay, a hedgehog, and a rat," \&c. This trap I propose should be called "The Happy Family Trap." Another ingenious pitfall is that in which a wheel, like a large water-wheel, is set in the run of the animal. One of the paddles of the wheel being exactly even with the ground, the animal treads upon this paddle. It instantly gives way with the weight of the animal, and lets it fall into a hole dug for the purpose; the next paddle of the wheel instantly comes down in the place of that which has just disappeared, ready for the next comer. This trap is called "The Habeas Corpus Trap." There is also a most ingenious mouse-trap, composed of a series of square pieces of wood hung on wires, so that should an animal (like a man crossing broken ice on a pond) attempt to cross over them, one or the other of the loose pieces of wood is sure to give way, and let him fall into the cavity below.

Next to the pitfalls should be mentioned the crushingtraps. Of these there are several kinds-especially one which has been long in use in Lord Spencer's park; and also a trap composed simply of a heavy log of wood and of two common boards. This trap is set by a most ingenious contrivance of two pointed fingers of iron; the animal steps on a treadle, and the log of wood falling on him immediately crushes him flat. This appears to be a trap which almost anybody can fit up with the rudest material; and what is its great advantage is, that it has no appearance whatever of a trap:-there being a free passage from end to end, and no bait whatever, suspicion is not likely to be aroused in the mind of the intended victim.

As regards the traps to catch alive, their name is legion. Several are modifications of the hutch-trap; some with doors at each end, some with a free passage through, and 
some with glass at one end, so that there is apparently a free passage through them. Then there is a trap for catching rats, in which there is a great improvement upon the ordinary piece of wire which the rat pushes up with hiss neck to get in. The pointed wire doors have not the individual wires fastened together, but they act independently like fingers of the human hand, so as to let in either a small or a large animal.

Another of the traps is a modification of the pitfall with the cage. The animal treads on the pitfall, and the cage in an instant springs up from an urseen locality, and covers him over. This is an ingenious trap, and deserves credit, especially for the formation of the springs, which are of india-rubber.

There is a curious trap in which the door is made upon the principle of the check-gate at the Zoological Gardens, so that the animal can go in one way, but cannot get out again; but the difficulty here seems to be that too much pushing is required. The most novel principle as yet applied to traps appears to be that in which a leaden ball (the size of a walnut) is made indirectly to close the door of the trap. The animal enters the door and advances towards the bait which is suspended for his benefit. As he walks along the board which forms the bottom of the trap, it gradually gives way with him, and as it gives way the leaden ball begins to roll down a trough by its own weight. This act of the ball disengages a chain, and instantly a door rises up at the end of the trap and shuts the animal in, so that the captured beast might well turn round and say to himself, "Who in the world shut the door behind me?" I should imagine that this principle would be well adapted for catching tigers in India.

It is to be remarked that, in all explanations of these traps, the animal to be caught is always supposed to go in at a certain place, and again the unfortunate rictim is always supposed to do exactly what the inventor wishes him to do. I am quite certain, however, that in many cases the animal 
will not be such an idiot as to do anything of the kind, for vermin are not such stupid creatures as many think them to be. In many instances, however, the vermin will be either trapped or else killed instantly, before, as the Yankees say, "he knew what hurt him."

Having arrived at their decision the committee issued the following circular:-

"Inasmuch as in the opinion of the committee and judges no model vermin-trap submitted to them fully answers the conditions of the advertisement, which offered a prize of $50 l$, it is now resolved that $10 l$. be awarded in one or more sums to one or more of the competitors, as the committee may shortly decide; and that the remaining $40 l$. be held in reserve towards a prize which it is proposed to offer early next spring, when a new competition and exhibition will be invited."

The best traps exhibited at the late trial are as follows:-

No. 44. The old steel trap provided with india-rubber gums, to hold an animal without injury; by the Rev. Mr. Baker, Hargrave Rectory, near Kimbolton; 5l. donation.

No. 87. A box trap, through passage, with large treadle, cleverly connected with doors which close the ends; by Nr. John Hancock, of Brunswick Mount, Nottingham; $3 l$. donation.

No. 49. A wheel pitfall.-The animal treads upon one blade of the wheel, and falls into the pit, carrying the wheel round until the next blade closes the opening; by F. E. Hooper, Esq., 17 Oxford Square, Hyde Park, W.; $2 l$. donation.

No. 17. A deadfall, very simple and effective; by Captain Darwin, of the Park, Buxton, Derbyshire; honourable mention.

No. 18. A deadfall; by Mr. W. Chouler, keeper to Earl 
Spencer, Harleston Park, Northamptonshire; honourable mention.

No. 14. A pitfall made of galvanised iron; by Mr. W. Roger's, Watford ; honourable mention.

- A box trap designed to kill.-A knife having three right angles is attached to protected door-springs, and is held down when set by a trigger; the treadle is laid in the bottom of box, and in the centre of a through-run. When the animal touches the treadle the trigger is removed, and the knife flies up with immense power, and, forcing the victim against the end of the box, instantly kills him; honourable mention.

No. 5. Several good house-traps by Mr. Pullinger, of Selsea, near Chichester; honourable mention.

Mr. Baker's trap certainly comes very near to the requirements first made public in the circular, and through the lindness of this gentleman I amenabled to give the following description of it. The motto of the trap is "Skandalon," a Greek word, meaning a piece of wood or trigger on pitfall or other trap, hence the words stumblingblock, offends, scandal. Mr. Baker believes the common steel trap to be as perfect, though cruel, in its way as anything that has been or can be invented. Taking this, therefore, for granted, his modification chiefly consists of substituting galvanised india-rubber jaws for the ordinary iron jaws. The result is that, instead of cutting into the flesh and bone, the trap grasps the animal's legs firmly between two elastic pads. These pads are found by experiment to hold an animal as securely as iron teeth, and frequently would prove more secure, as the leg is often sawn or torn off in the old trap, while the suffering animal escapes. The advantages, therefore, gained are, first, no actual torture is inflicted ; secondly, no injury is done to the animal if it be wished to release it, or secure it alive. It has been tried before a party of witnesses, and found to succeed perfectly.

The box trap invented by Mr. Hancock is admirably suited for taking animals alive without injury to them. It 
consists of a box open at each end, with an apparently free run or passage through it. In the middle of the trap is placed a treadle, and when the animal touches this a wire door falls down upon the top of the box by its own weight, and closes the entrance. I have tried this with a rabbit, and it works very well.

The wheel pitfall invented by Mr. Hooper I have already described; but I may as well repeat that it consists of a wheel like a mill wheel, of four flaps: one flap is set flush on a level or even with a hole.in the ground; the animal treading on it falls into the hole, and at the same time sets it again, another flap of the wheel comes round, and constantly adjusts itself in the place of that which has just fallen. See drawing, "Land and Water," Nov. 1867.

Captain Darwin's deadfall consists of three rough pieces of wood nailed together, so as to form a run of about three or four inches in diameter; above the run is placed a heavy block of wood, or a block loaded with lead; the animal passes through the run, which certainly looks very inviting to such a creature as a rat, stoat, or weasel; he touches a trigger, and the block from above is set free by a most ingenious catch. Any village carpenter could knock up a trap on Captain Darwin's principle in an hour or so, and the idea does the captain much credit.

The deadfall exhibited by Mr. Chouler is rather more complicated than that of Captain Darwin; but, from the fact that it has been used for very many years in Lord Spencer's park, there can be no possible doubt that it is a first-class instrument.

The pitfall of galvanised iron, invented by Mr. Rogers, may be described as follows:-The lid of a square box is sawn in halves down the middle, and each half is set so delicately by hinges, that any creature which places his foot upon it is quite certain to fall into the pit below. This is what I took the liberty of calling the "Happy Family Trap" in my last description, as it would catch anything, from a toad up to a jay. 
The killing box-trap is certainly a most formidable guillotine-like instrument: I trust the inventor's fingers may not meet with the same fate by his own trap as did the head of the unfortunate inventor of the well-known French decapitator, the terror of revolutionary times.

Mr. Pullinger's house-traps are already known to the public, and they are certainly very good.

\section{NEW ZEALAND MOA.-VoL. II. PAge 70.}

The "Daily Southern Cross," of March 6, 1863, gives the following :-

"Two men started from the Arrow-township in search of gold about twenty-five miles north-west of the Arrow. They were sitting by their camp fire when they beheld an enormous bird approaching to the edge of a hill immediately above them, at a distance of between 300 and 400 yards from where they were sitting. The bird seemed to perceive the camp fire, and squatted down, keeping its head turned on one side, fixed on the fire. It continued so for several minutes, and at last got up and walked off. Although it stepped slowly it was soon out of sight, the length of its stride being so great. Its height appeared about seven feet, without reckoning the head and neck. Its head was very long and flat, and it carried its neck bent forward instead of carried back, as is usual with birds of the ostrich species."

The last evidence of Dinornis having been seen by human eyes previous to that now placed on record occurs in a letter from the Rev. W. Williams to my Father, Feb. 1842. Mr. Williams writes :-

"I have obtained information worthy of notice. Happening to speak to an American about the bones, he told me that the bird is still in existence in the neighbourhood of Cloudy Bay, in Cook's Straits. He said that the natives had mentioned to an English whaling party that there was 
a bird of extraordinary size to be seen only at night on the side of a hill near there, and that he, with the native and a second Englishman, went to the spot; that after waiting some time they saw the creature at some little distance; they described it as being fourteen or sixteen feet high. One of the men proposed to go nearer and shoot, but his companion was so terrified, that they were satisfied with looking at him; in a little time he took the alarm, and strode away up the side of the mountain."

In an article in "Land and Water," No. 95, on some exceedingly fine specimens of Dinornis bones, by Mr. Charlesworth, a letter is quoted from the Rev. Richard Taylor, of New Zealand, dated London, October 5, 1867. He writes :-

"I believe this wonderful race of birds is not yet quite extinct in New Zealand. Dr. Hector, the Government geologist, discovered their tracks in the scrub on the mountain ranges of the middle island, and gold-diggers, on two occasions and in widely-separate districts, affirm that they have seen it, in both cases in the dusk of evening; and Mr. Maling, a Government surveyor, met with the tracks of one on some moist ground, which he carefully measured, and found the imprints were fifteen inches long, with a stride of nearly six feet; but as this race are doubtless night birds, like the apteryx, and solitary in their habits, resembling the dodo, it is not at all wonderful that they have hitherto escaped being captured, their haunts being in wooded sides of mountains, where man seldom, if ever, penetrates; but I shall not be surprised to hear that one has been taken, as the solitary specimen of the Notornis was, which Mr. Mantell procured and sent to the British Museum, where it may now be seen.

"To Edwd. Charlesworth, Esq."

"Richard TaYlor.

On November 24, 1865, Mr. Stevens sold by auction an egrg of the Moa or Dinornis. It was discovered at Kai Koras, by the side of the skeleton of a man; the egg must have been placed in his hands. It is about ten inches in 
length, and seven inches in breadth, the shell being of a dirty brown colour, and rather thicker than a shilling; the inside is quite clean. This specimen, which I understood had been insured for $1000 l$., was bought in at $200 l$.

\section{FLEAS.-Vol. II. Page 115.}

In 1836, a paper was read before the Ashmolean Society at Oxford, by the Rev. J. Hussey, upon the growth of the flea. "The flea lays from eight to twelve eggs, which fall down into crevices or among dust, where they are hatched in about five days. They produce small white maggots, like cheese mites, which increase in size for about fourteen days, when they spin a bag or case of silk around them, and become chrysalids. Within this case they gradually turn darker in colour, until at the end of about sixteen days they come out perfect fleas, having been on the whole about thirty-four days from the laying of the egg to a perfect state. The growth of the flea may be retarded by temperature; they can survive the action of wet for upwards of twenty-four hours. A maggot in the earliest stage was found to live between two and three weeks without food. Dr. Buckland mentioned that he had opened boxes which had been packed at Naples three years before, and found in them great numbers of large fleas in full activity. He believed that the maggots were fed by the scales and scurf which fell from the skin of animals, while the full-grown fleas lived on blood alone."

I believe the herb feverferw, which can be bought at Covent-garden, will keep fleas away; anyhow, moths will not come near it. It is a capital thing to hang up on or sew into the linings of carriages.

"To Drive away Fleas. - Take a few handfuls of fresh garden mint, and strew them about the rooms, particularly under the beds. This plan I adopted when on the Neilgherry Hills, with perfect success." $-A$ Subscriber, "Land and Water." 
"It was once our fate to take a house in which we succeeded an Irish family, who bequeathed us a most abundant legacy of the jumping gentry. We placed bunches of wormwood under the beds, and burnt it freely in the rooms ; the fleas soon disappeared." $-E$. $W$.

"Fleas in Dogs.-Procure six or eight gallons of gaswater from some gasworks. Put the liquid into a large tub, and then introduce 'Sancho' and all his host of friends. After a few minutes, you will find not one is left to tell the tale, or tickle Sancho's tail either. You must keep good hold of the dog while he is in the tub, and be sure to keep the water out of his eyes and mouth. Ten gallons would wash a pack of hounds."-Randam.

"Rub them well over with whiskey-it acts like magic, killing the fleas instanter; if all are not polished off in one application, another will be necessary." $-H . S$.

"To Destroy Fleas in Floors.-Make a strong decoction of laurel-leaves, boiling them for four or five hours. Deluge the floors with the boiling hot liquor. The liquor will but very slightly discolour the ceilings, which of course can be whitened again."-Builder.

Fleas in Monkeys.-Mr. Bartlett tells me he gets an old, very dirty meerschaum pipe, and soaks it in spirits of wine. With this tobacco oil spirit he rubs the skins of the monkeys, and the colony of the "Poux" family depart. The monkeys thus treated were spider-monkeys, and very valuable.

I hear camphorated spirits of wine sprinkled on the blankets under the sheets will keep fleas from biting.

\section{CORONERS' INQUESTS.-Vol. II. PAGE 219.}

It would take a whole chapter were I to describe in detail the many curious and, I may say, ghastly sights which came under my notice during the sixteen long days I spent in this dismal necropolis. I cannot, however, resist mentioning one or two curious things, viz.:-

SER. III.—VOL. II. A A 
1st. The discovery of many bodies that had been buried in woollen; according to an act of parliament passed "That all persons should be buried in woollen," in order, I believe, to encourage the wool trade, which was at that time in a state of depression. The date of the passing of this act I know not; I have, however, among my Father's old papers, a copy of

" $\mathrm{A}$ register of all the affidavits of the parish of Combepyne (Devon) according to a late act for burying in woollen, 1678."

The first entry is as follows:-

"An affidavit for the interment of Anne Collings was brought unto me, Rich. Pinney, minister, the 11th day of March, 1678."

The dates following are 1679, so that the act must have been passed before 1678 .

My friend, the Rev. A. Taylor, chaplain of Gray's Inn, has just been kind enough to give me the following:-

"Burying in woollen, 18 Charles II. c. 4 (1666).

"Repealed, and new statute framed, 30 Charles II. § 1, c. 3 (1677).

"Repealed, 54 Geo. III. c. 108 (July 23, 1814)."

Horwood House, Bideford, Devon. October 24, 1866.

Sir,-In your 2nd volume 3rd series of "Curiosities of Natural History," you speak of burying in woollen. I trust I may not be deemed intruding in writing to you on this subject. In the Register Book of Burials of this Parish, the first entry of burying in " woollen only," is in the year 1678 , and so continues till 1724, the last entry in "woollen only" being in 1723. I find the following entry in the year 1684:-

"John Dene, Gent. was buryed in Linnen the 19th day of February, for $w^{\text {ch }}$ (next word illegible) hath been payd 5 pownd, viz. 50s, to the informer, and $50 \mathrm{~s}$. to $\mathrm{y}^{\mathrm{e}}$ pocre of this parish, according to the act for buryeing in woollen."

F. Buckland, Esq. Yours faithfully, Arthur Dene, Rector of Horwood.

Act for Burying in Woollen.

In Mr. Buckland's third series of Curiosities, vol. ii. page 304, he refers to the act of parliament for burying in woollen, and writes "the date of the passing of this act I know not." Subsequently, 
2nd. The discovery of a coffin among those of a very old date under the tower of a church in which a very curious,

however, he gives the act 18 Charles II. (1666). The practice would seem to be much older, whatever may have been the law upon the subject.

In "Much Ado About Nothing," Act ii. Scene 1, Beatrice says, "Lord I could not endure a husband with a beard on his face; I had rather lie in the woollen."

This play is stated in the introductory notice (see Knight's edition) to have been printed in 1600 . Does not Beatrice allude to the custom in question, and mean in her lively way to say, that she considers death preferable to a bearded husband?

If so, the practice must have been a practice of notoriety nearly a century before the act of parliament was passed making it compulsory.

Antiquarian.

Sir,-I feel some difficulty in adopting the suggestion of "Antiquary," as published in "Land and Water," that the pretty impertinence put into the mouth of Beatrice in "Much Ado about Nothing," "Lord I could not endure a husband with a beard on his face; I had rather lie in the woollen:" has reference to the custom of burying the dead in woollen at the time the play. was written. In Malone's edition of Shakespeare, I find the following note to the above passage, which appears to have been borrowed from Sterens. "I suppose she means between blankets and without sheets," and this I also take to be the lady's meaning.

This explanation is somewhat favoured by the interpretation given in Johnson's Dictionary of the word "woollen," which is as follows: Made of wool, not finely dressed, and thence used for any thing coarse ; it is likewise used in general for made of wool, as distinct from linen; and then among other quotations illustrative of the true meaning of the word occurs in the very passage under consideration, "Both linen and woollen fabrics were in use in this country at a very early period." Haydon, in his "Dictionary of Dates," tells us that woollen cloths were an article of commerce in the time of Julius Cæsar; that they were made in England before A.D. 1200, and that the manufacture became extensive in the year 1331, when the art of weaving it was introduced from Flanders. Linen, as appears from the same authority, was first manufactured in this country by Flemish weavers under the protection of Henry III.; and it further appears that a company of linen weavers was established in London in 1368. It seems probable that both textures were commonly and indiscriminately used for the purpose of burial down to the passing of the statute 18 \& 19 Car. II. c. iv. After giving the reasons for passing the act by way of recital which are stated to be "for the encouragement of the woollen manufactures of this kingdom, and prevention of the exportation of the monies thereof for the buying and importing of linen," the first section enacts "that from and after the five and twentyeth day of March in the yeare of our Lord one thousand six hundred and sixty sevean, noe person or persons whatsoever shall be buried in any shirt, shift, or sheete made of or mingled with flax, 
and, I believe, hitherto unobserved change had taken place. Among other coffins, I observed one the wood of which had crumbled into dust, exposing what I at first thought was a coffin made entirely of beautiful white porcelain. On closer examination of this coffin, as the men moved it, we found that it was not solid, but very easily broken.' I suspected that it was the lead of the coffin, by some mysterious agency, converted into a new substance. A chemical friend, therefore, kindly examined it for me, and reported that it was pure carbonate of lead.

How this remarkable chemical change took place, I know not. I believe it is the only case on record. I have deposited a specimen in the Museum of the Royal College 'of Surgeons.

3rd. An anti-resurrectionist coffin; the peculiarity of which was, that the upper lid was fastened on to the lower lid by strong moveable $\mathrm{V}$-shaped, steel springs, which rendered it morally impossible for resurrectionists, or any one else, to break the coffin open from without. Of course we had no idea why this precaution was necessary in this individual case. We found no other like it.

4th. A leaden coffin, which, from the sound, was evidently three-parts filled with fluid. This, too, was a mystery; it was almost as round as a cask.

5th. A very remarkable, and at the same time peculiar crystallisation upon some of the bones. The crystallisation was in delicate and exceedingly fragile glass-like spiculi, and covered some of the specimens, especially inside the

hempe, silke, haire, golde or silver, or other than what shall be made of wooll only," under a penalty of five pounds, with a proviso that the penalties of the act shall not apply to cases where persons dying of the plague are buried in linen. This statute being found insufticient for the purpose for which it was intended was repealed, but in substance re-enacted and with additional stringency by the 30 Car. II. c. iii. which last act was subsequently amended by 3̈2 Car. II. c. i. Both these latter enactments were in their turn repealed by the 54 George III. c. cviii., by which all pre-existing restrictions upon the subject of grave-cloths were abolished.-Land and Water. 
skulls, like the hoar-frost we often see on fine frosty winter mornings.

The reader may ask how we managed to see all this, as above described. In a great portion of the vaults, we found that the bodies had been buried without lead, anterior to the act for burying in lead. In many instances the wood of the coffins had quite decayed, leaving the contents, in some instances, in the state of a mummy ; in others, simply a heap of loose bones. In the more remote parts of the vaults, where the coffins were of great age, we frequently found simply dust-the dust of death.

I refrain from giving further particulars : suffice it to say, that the facts brought under my notice convinced me of the terrible danger which must have arisen in former times from the fact of the vaults being below the church to those who attended Divine worship in the church, many of whom, doubtless, owed serious attacks of illness, if not worse, to the mephitic vapours inhaled.

The act, therefore, which forbade any further interment in vaults under churches was one of the wisest ever passed for the benefit of the community at large.

During all the operations carried on under the vaults, the churchwardens spared neither time, nor trouble, nor expense in anticipation of any mischief that might arise to ourselves or the labourers. I must here compliment them upon the manner in which they carried out their task with the utmost possible decency and order.

\section{TRANSPORT OF LIVE SALMON FROM WORCESTER TO LONDON.-Vol II. Page 295.}

When I arriced at the Ferry House, near Worcester, where Mr. Allies had conducted me with my male trout, in order to carry out my long-desired experiment of making a hybrid between a trout and a salmon, I asked the owner of the salmon-nets if he had a live salmon by him. By the 
greatest good luck he had two in the well of his boat. The idea flashed across me that if I could only get one of these fellows to London, we might learn very much, not only as to the practical conveyance of fish for long distances, but also as to what would happen to a salmon if confined in a pond. Mr. Allies, with that enthusiasm which characterises him, immediately jumped at the idea. "You can but try it," said he, " and I will lend you my fish-carrier." "What's the price of the salmon?" said I. " $3 s .6 d$. a pound," was the reply ; " and they are selling at Worcester for $4 s . " \quad$ As that would bring up the cost of one of the live fish to about 30 s., not including the expense of "portage," I was almost afraid to risk the expense; but Mr. Allies suggested that if the fish did die, one of the London fishmongers would take him as an article of food, as I could warrant him fresh; and that he was not like the poor porpoise, at whose deceased person everybody turned up their nose. "I will try it," said I, " and if I fail I shall know better next time." So we pulled up to the bank the boat, in the well of which the salmon were confined, and chose one immediately, and Mr._ carried him on shore and weighed him, while I stood in the cart by the watercarrier, ready to receive my charge. The fish was put in a net, and the net suspended on to the weighing-scales. The stupid salmon would not keep steady; he flopped his tail first to the right and then to the left, and his scales flew off him like a shower of snowflakes, and he disturbed the balance of the machine so much that it was impossible to tell his weight. At last he was a bit quiet, and the just weight settled. "In with him into the carrier. Look sharp!" said I. We tumbled him in directly, but he was so exhausted that he almost immediately turned on his back, and I thought he would have died then and there. Seeing this, I refused to take a semi-dead and faint fish like this, and said, "I must have the other salmon, even if I pay for a pound more than his real weight!" After a time we came to terms, and rushing down to the well-boat, I got hold of the tail of 
the other salmon. How he did kick to be sure! I never put him near the weighing-scales, but into the carrier in a moment. "Away with you, driver, as fast as you can go, for Worcester!" We had not gone very far, when the motion of the carriage caused the water to slop over. So we sounded a halt, got the lid of an old hamper, twisted up a lot of briar brambles (which an old hedger and ditcher cut for us), bound it round the hamper-lid into the form of a garland, and started again. On my road to the Worcester station Captain Coventry luckily met me, and asked if he could be of any service to me. "Do you know the stationmaster? because if you do, please introduce me, and say who I am and what I want." He jumped up into the cart with us, and introduced me to Mr. Beauchamp, the most obliging aud polite station-master at Worcester, to whom I am much indebted for his great kindness and civility; for when the train came up he put myself and the salmon into the guard's van, the whistle sounded, and away we went. As the pace increased, the water in the huge heavy fishcarrier, first began to dance about, then to get a good strong: ripple upon it, and at last splash-splash, bang-bang, it went in huge waves right over the sides of the tank, and through our briar garland, flooding the whole van, and making as nice a mess as ever I wish to see. The guard piled up all the luggage - and there were luckily only a box or two - while I set to work to blow the salmon vigorously. The reader must understand that if you cannot give a delicatelived fish, like the salmon, a constant flow of water, he will very soon die, and this because his gills are so constructed as very soon to exhaust all the oxygen from a given quantity of water. In order, therefore, to supply this oxygen Mr. Allies had fitted at the bottom of his fish-carrier two pipes with holes perforated at the sides, and at the end of one of them an attachment for a pair of bellows. In order, therefore, that the water should be perpetually oxygenated, it was necessary to keep this air-pump going continually. The splashing of the train spilt so much water out of 
the tank that the salmon's back became visible, and by his kicking and plunging his head out of the water he showed he wanted more air; so I pumped furiously at him; the guard, an excellent fellow, taking a spell at the pump when I was tired; and so we went on till we arrived at Chalbury station. Here we stopped a couple of minutes, and the engine-driver, who was filling the boiler of his engine, kindly turned the hose round, and I had just time to fill three buckets with water and put them in with the salmon; he answered to it immediately, going deep down into the water, and recovering from his fainting fit. Thinking how I might prevent further splashing, I rolled up two newspapers, pocket handkerchiefs, a pair of trousers, \&c., and jammed them between the briar garland and the edge of the tank; and this answered capitally till we got to Oxford, I and the guard blowing at him all the time. The water became, however, full of bits of the newspaper, and the poor salmon was evidently very uncomfortable, if I may judge from his kickings and plunges for fresh air.

At Oxford I and the salmon had to change trains, and twenty minutes to wait. I enlisted two porters to drag the salmon in his tub to the nearest tap-the other side of some iron railings, of course-and I gave a fly-driver a fee to keep handing me over buckets of fresh water, which I poured right down upon the fish from a height; again his faintness went away, and he sneaked down to the bottom of his prison, and I still had hopes of bringing him to London. A crowd collected, of course, and the remarks were amusing. "What the deuce has he got there?" "Gold fish," said one; "A sea-snake," says another; "A young whale," cried a third ; "It's Dr. Buckland's man has got a live curiosity for his master," said a fourth. They might well call me "the man," for my wading-boots were one mass of Severn mud, and my coat nearly wet through, and I have no doubt I looked a pretty guy. "Here, some of you,"said I, "just take a turn at the bellows, please." Not une of the lookers-on would help a bit, except a medical gentleman (Dr. C.), who 
happened to be in the train, and who gave me his assistance. Up comes the train, and not a minute to spare. The guard demurs at putting "my luggage" into his van. I was in agonies. Then came the station-master. "Anywhere," said he (and many thanks to him), "only make haste; the man must go with his master's fish." He then opened a mysterious cupboard close behind the engine, and six porters and myself lifted in the salmon. I got in also, and the porter closed the doors. It was as dark as pitch, so I instantly struck a vesuvian, and perceived that I was literally in a close shut iron box, and not a breath of air to be had. "Good heavens!" I thought, "if I stay in here, I shall certainly be suffocated, and the train only stops once between Oxford and London." So I kicked and bellowed till they opened the door and let me out; and I had just a moment to hop into a sort of narrow cage, where there was nothing but a great wheel, and only just room to move, and from which I could shake hands with the engine-driver.

Away we went, like lightning, and after a sharp spin through the air, we arrived at Reading. "A shilling a bucket for water!" I exclaimed, as we ran into the station. One of the porters luckily heard me, and the moment the train stopped I got to the salmon-and not a moment too soon, for the water had nearly all splashed out of the carrier, and he was almost high and dry. While the porter poured in the water, I kept pumping the fish ; but fearing suffocation in the iron cupboard, I again retreated. After a tremendously anxious time of suspense, at last we ran into Paddington. I immediately rushed to the salmon. "By Jove, he is dead! the experiment has failed !" said I to my friend Bartlett, of the Zoological Gardens, who had come to meet me. "But there is just a chance. Get some porters; I know where the water-tap is, just behind the cabs there." So the men half-carried half-pulled the tank up to the water-tap; and one of the men, seeing how bad the salmon was, most kindly turned on the fire tap and let in a deluge of water right on to the fish, letting it run for twenty minutes. 
This saved the salmon's life; he soon turned right way up again, and swam round and round as though he was back again in the "boiling water" at the Worcester weir.

When he seemed all right again, we managed to get him up into the cart, which jolted so fearfully with the weight that I was obliged to stop twice, at two cab-stands, and fill up from the waterman's bucket. We drove at a gallop straight to the Zoological Gardens, and, lighted by a lantern, went at once to the sturgeon's pond. Lifting the tank over the railing of the pond, I got into the water, and slid the salmon gently into his future home; he made two or three jumps right out of the water, and was then quite quiet. "Thank goodness," said I, "you will not want any more blowing with the bellows to-night. So good luck to you, and mind you don't quarrel with the sturgeon!" The next morning I went to see my friend, and was most pleased to find that he had passed a comfortable night. There is a big stone in the middle of the sturgeon's pond, underneath which the royal fish is accustomed nightly to repose. The salmon had taken possession of these comfortable quarters, and turned the sturgeon out, for being also the king of fish he disputed his right to the throne. For three or four days nothing was seen of the salmon; he sulked under his throne, and would not show himself to his numerous visitors.

The sturgeon meanwhile was positively furious; he swam round and round his pond with the indignant air of a muchinjured and insulted fish. "Confound that Frank Buckland! The other day he put a great oily porpoise into my pond! and now he comes, in the dead of the night, when all good fish ought to be abed and asleep, and turns an upstart thing like a salmon positively into my bed. What next, I wonder ! By Jove, I'll write to the 'Times' again, if I am perpetually to be made game of in this manner. Confound your novelties! $I$ am the fish that everybody ought to come and see."

The last news, however, is that the salmon and the sturgeon have made peace together, and that yesterday moruing 
Mr. Bartlett saw the two royal fish swimming quietly, finin-fin, for a morning's airing round and round the pond.

And now comes a most interesting fact, which we have already discovered. Mr. Bartlett thought he would try the fish with all sorts of food likely to be palatable. Tennant, the keeper, therefore took a number of lively roach and dace and threw them in to the salmon. The salmon came out instantly from under his stone, and in a moment made an arrow-like rush and a dash at the little fish, and snapped up four or fire in an instant. As is the case with all caged animals-whether man, beast, or fish-prisoners are very shy during the first few days of captivity, and will not feed. When once, however, they find their appetite, they will get on well. Our pet salmon has begun to feed (tbough I am sorry to see a little white fluff growing about his scales) and we have great hopes of his ultimately living and doing well.

I must here again return my sincere thanks to Mr. Allies, without whose valuable assistance I should have been unable to carry out my experiments; and also to Mr. George, and several members of the Worcester Fisheries Preservation Society, who showed me the greatest lindness and attention.-Feb. 27, 1864.*

\section{BOG BUTTER.-Vol. II. PAge 313.}

"There can be no doubt that the substance found in the bog near Oughterard (as mentioned by Mr. Buckland in Chapter IV. of his 'Run through Connemara and Galway') had at one time been butter. A moment's reflection will suffice to inform Mr. Buckland that a pure animal fat, such as butter, would be much more readily converted into adipocere than 'the muscular and all other soft parts' of dead animals. It is well known to Irish antiquaries that butter formed the principal animal food of the ancient Irish; that they did not like it in a fresh state, and so buried it in

* I regret to say the salmon soon became covered with white fungus, and died in a few days. 
bogrs, to acquire thereby a rancid flavour. 'De gustibus non est disputandum.' The celebrated statistician and political economist, Sir William Petty, when describing the food of the Irish, about the middle of the seventeenth century, includes 'butter made rancid hy keeping in bogs,' and by way of adding a pungency to this rancid flavour, the butter was not unfrequently mixed with garlic, as we learn from the 'Hesperi-neso-graphia,' published towards the close of the seventeenth century, where bog butter, as one of the household stores of a native Irish gentleman of the period, is thus alluded to :-
But let his faith be good or barl,
He in his house great plenty had
Of burnt oat bread, and butter found
With garlic mixt, in boggy ground,
So strong, a dog with help of wind,
Bv scenting out with ease might find.
And this they count the bravest meat
That hungry mortals e'er did eat.

As may readily be supposed, considerable quantities of this bog butter, through various accidents, have not been disinterred until our own times; and thus it forms one of the more familiar objects to Irish antiquaries. In the museum of the Foyal Irish Academy there are numerous specimens of bog butter, all changed into a perfect state of adipocere, generally resembling hard dry Stilton cheese. There are also the various tubs, firkins, methers, and other wooden vessels in which it is generally found; and in some instances it has been discovered carefully wrapped up in folds of linen and woollen cloth. Indeed, there is scarcely a local or private collection of antiquities in Ireland which does not contain specimens of a similar description. I may add that this bog butter has been frequently analysed by chemists of European reputation, and in every instance the result proved that it had been originally butter: that is to say-and Mr. Buckland will no doubt understand me-as far as chemical analysis can distinguish between adipncere tormed from butter and the same substance formed from a dead animal. I imagine there are certain chenical condi- 
tions that would effectually prevent a pig or cow that had been buried in a bog from being subsequently raised 'under the form of a keg of fossil butter,' even if the well-known antiseptic qualities of the bog did not bar such an unphilosophical transformation. Many curious and startling stories could be told of the antiseptic nature of bogs. Thus, a few years ago some turf-cutters found the body of a man in an Ulster bog; and so well was this body preserved, that an active constabulary officer noticed the coroner, and summoned a jury to hold an inquest on the corpse, which, from its skin dress, had probably been dead not less than 300 years."-William Pinkerton, F.S.A.

\section{"Rectory, Guisnay, "June 6,1867 .}

"Mr Dear Sir,-There can be no doubt but that the substance you allude to is butter: you can melt it over the fire, and though rancid it has all the property of butter; it is known that the ancient Irish were partial to rancid butter, and buried it in bogs to give it the desired flavour; often, too, it was buried for safety, and in both cases, often forgotten, and so has remained for us to discover.

\section{"Yours truly, \\ "T. Groves."}

"The 'pig,' or 'bear,' or ' black horse,' found in the bog, according to so many learned authorities, proved on my visiting it to be simply a mass of rolled fibrous peat, the edges of which, having lost their pulpy and softer parts, left the fine fibres free. I admit that at first sight the resemblance was very close, and that a cursory inspection would impress the mind with the idea of some large animal included in the mass. The fibres were long and silken, and waved freely in the wind, but could be distinctly traced into the imbedded leaves of some aquatic plant, and on being burned in the candle gave the usual peat or gorban odour."-F. C.J. 
LONDON

PRINTED BY SPOTTISWOOBE AND CO. NEW-STREET SQTARE 


